University of Louisville

ThinkIR: The University of Louisville's Institutional Repository

Electronic Theses and Dissertations

$12-2020$

\title{
In need of a hero? the creation and use of the legend of General George S. Patton, Jr.
}

Nathan Curtis Jones

Follow this and additional works at: https://ir.library.louisville.edu/etd

Part of the Cultural History Commons, Military and Veterans Studies Commons, Military History Commons, Organization Development Commons, Other Social and Behavioral Sciences Commons, Policy History, Theory, and Methods Commons, Sociology of Culture Commons, and the Work, Economy and Organizations Commons

\section{Recommended Citation}

Jones, Nathan Curtis, "In need of a hero? the creation and use of the legend of General George S. Patton, Jr." (2020). Electronic Theses and Dissertations. Paper 3569.

https://doi.org/10.18297/etd/3569

This Doctoral Dissertation is brought to you for free and open access by ThinkIR: The University of Louisville's Institutional Repository. It has been accepted for inclusion in Electronic Theses and Dissertations by an authorized administrator of ThinkIR: The University of Louisville's Institutional Repository. This title appears here courtesy of the author, who has retained all other copyrights. For more information, please contact thinkir@louisville.edu. 
IN NEED OF A HERO? THE CREATION AND USE OF THE LEGEND OF GENERAL GEORGE S. PATTON, JR.

\author{
By \\ Nathan Curtis Jones \\ B.A., University of Oklahoma, 2008 \\ M.A., University of Missouri - St. Louis, 2010

\begin{abstract}
A Dissertation
Submitted to the Faculty of the

Graduate School of the University of Louisville

in Partial Fulfillment of the Requirements

for the Degree of
\end{abstract}

Doctor of Philosophy

in Interdisciplinary Studies

Interdisciplinary Studies

University of Louisville

Louisville, Kentucky

December 2020 
Copyright 2020 by Nathan Curtis Jones

All rights reserved 



\title{
IN NEED OF A HERO? THE CREATION AND USE OF THE LEGEND OF
} GENERAL GEORGE S. PATTON, JR.

\author{
By \\ Nathan Curtis Jones \\ B.A., University of Oklahoma, 2008 \\ M.A., University of Missouri - St. Louis, 2010 \\ A Dissertation Approved on
}

October 20, 2020

by the following Dissertation Committee:

Robert Carini, Ph.D., Sociology Department, Committee Co-Chair

Daniel Krebs, Ph.D., History Department, Committee Co-Chair

D. Mark Austin, Ph.D., Sociology Department, Committee Member

Gary Gregg, Ph.D., McConnell Center, Committee Member 


\section{DEDICATION}

This dissertation is dedicated to my wife

AnnLouise, my son David, and my mentor and friend

Ms. Alice Hart.

My name may be on the diploma but it is all yours

as much as it is mine.

And to "Georgie" and the men who "fought with Patton."

Heroes get remembered. Legends never die. 


\section{ACKNOWLEDGMENTS}

I would like to thank my committee co-chairs, Professors Daniel Krebs and Robert Carini for their guidance, patience, and wisdom over the past six years. I would also like to acknowledge the many contributions made by another committee member, the late Professor Jon Rieger, who passed away months before my defense. He pushed me to go beyond what I thought were my capabilities and helped me see areas of opportunity. He will be sorely missed. I would also like to thank the other committee members, Professor D. Mark Austin and Professor Gary Greg, for their comments, constructive criticism, and assistance. Without the committee's critiques, I would never have been able to clarify my arguments. I must also acknowledge Dr. Jonetta Weber and the Sociology Department for adopting an Interdisciplinary Studies Ph.D. candidate and for assisting in many of the administrative tasks required to make this possible. Also, a heartfelt thank you to my former supervisor, Ms. Alice Hart, who understands the value of intellectual endeavors and allowed me to pursue this adventure. Without her support this would not have been possible. I would also like to express gratitude to my wife, Annie, for her understanding and patience when times seemed bleak. I am forever indebted to her for her keen editing skills (having someone at home with a degree in English was invaluable) and for allowing me to use her to test ideas and concepts. When I thought the struggle was not worth it, she encouraged me and reminded me that some things are just bigger than you. And to my son David, whom I hope I made proud. Remember, son, cool guys read books. 


\begin{abstract}
IN NEED OF A HERO? THE CREATION AND USE OF THE LEGEND OF GENERAL GEORGE S. PATTON, JR.

Nathan C. Jones
\end{abstract}

October 20, 2020

During WWII, General George Patton became the hero Americans needed through the creation of a self-crafted brand and with help from journalists. After Patton's death, opportunists forwarded a legend narrative that developed into a collective memory that morphed over time to meet contemporary challenges. Stakeholders of that collective memory commemorated and memorialized the dead hero for monetary and political gain, to promote patriotism, make military doctrinal changes, and even promote peace. Today, this collective memory has potential for the U.S. Army as it transforms civilians into soldiers and officers.

This study contributes to history and memory studies by linking representations of an historical figure to targeted audiences, arguably, the first of its kind. As an interdisciplinary study utilizing empirical historical and qualitative sociological methods, it adds to extant literature for multiple disciplines by providing explanatory insight into the use of hero narratives by individuals undergoing a transformational process.

The dissertation is divided into two parts. Using archival and material culture evidence, Part 1 discusses the creation and promulgation of the Patton collective memory and applicable theories and research on memory, ultimately relating it to the legacy of 
leader development and operational doctrine Patton left for the Army. Part 2 defines the Army as a subculture and introduces the importance of heroes in general. Evidence from in-depth individual interviews with 27 Reserve Officer Training Corps cadet volunteers from a single university in the spring of 2020 forms the basis for a proposed grounded theory, the Transformative Hero Model. The model is informed by several orienting theories including Affective Disposition Theory, Sense-making Theory, and Self-efficacy Theory.

Cadets undergoing the Army's transformational process used hero narratives to develop themselves and understand their place within an organizational subculture. Whom cadets found inspirational and how they connected to and used those narratives centered on their sense of self. They also used hero stories in their socialization process by adopting a shared heritage and internalizing value structures. Furthermore, they began to differentiate themselves from out-group members while simultaneously increasing identification with their subgroup. Organizations that use transformational processes may leverage hero narratives by using this model. 
TABLE OF CONTENTS

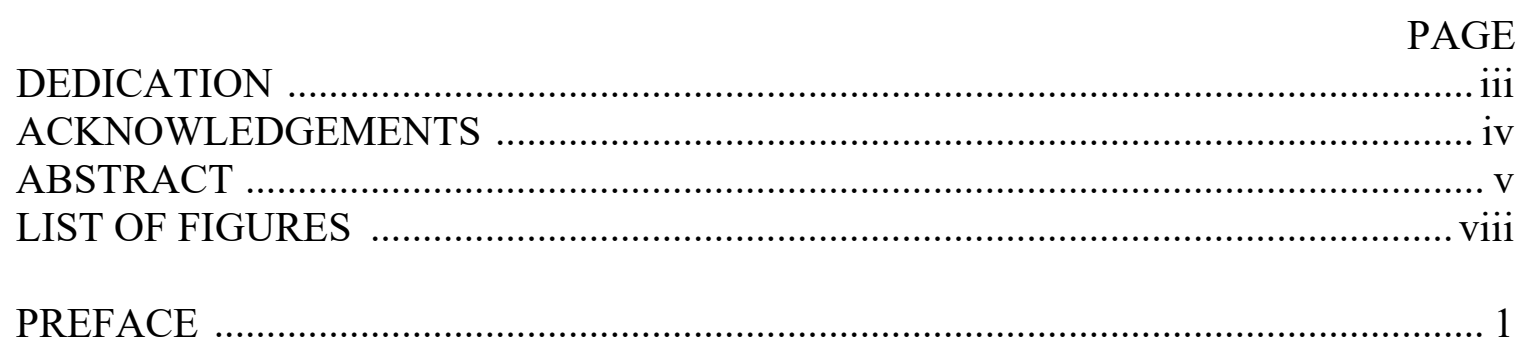

PART 1: THE MAKING OF A HERO …............................................................... 4

CHAPTER I: COMPETING NARRATIVES ........................................................... 4

CHAPTER II: A LIVING LEGEND ..................................................................... 25

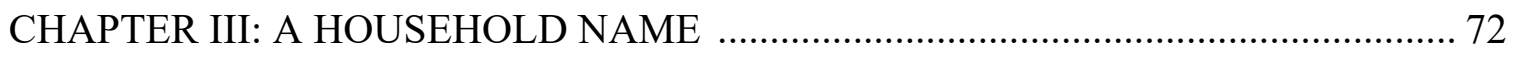

CHAPTER IV: A COLLECTIVE MEMORY ….................................................. 131

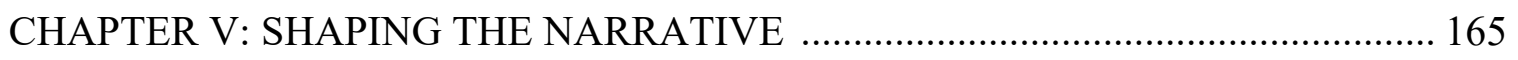

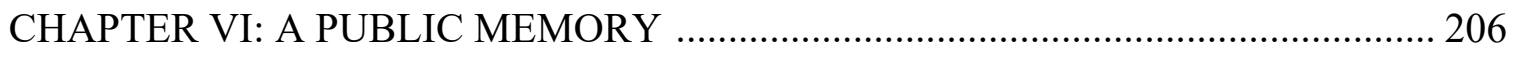

CHAPTER VII: THE PATTON LEGACY …..................................................... 265

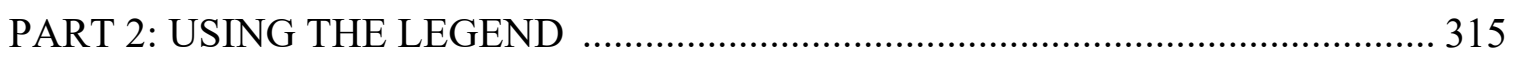

CHAPTER VIII: THE ARMY COLLECTIVE AND SUBCULTURE ....................... 315

CHAPTER IX: IN WANT OF A HERO ............................................................ 343

CHAPTER X: HEROES AND TRANSFORMATIONAL PROCESSES ................... 366

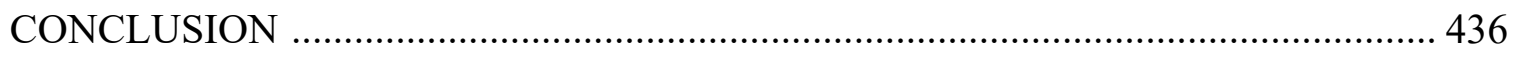

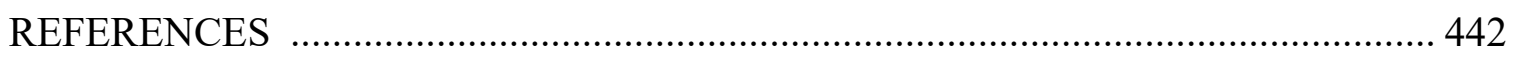

APPENDICES: KEY TERMS, INTERVIEW GUIDE, AND QUESTIONNAIRE ..... 463

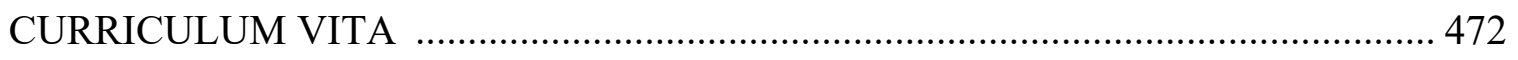




\section{LIST OF FIGURES}

FIGURE

PAGE

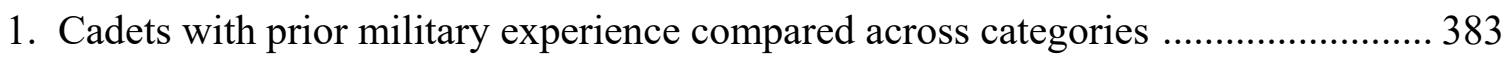



3. Comparison of most often reported familial ties across categories .......................... 385

4. The Transformative Hero Model: A Grounded Theory ........................................... 417 


\section{PREFACE}

Every researcher setting out to write something meaningful needs a problem, otherwise there is no reason to embark on such a daunting challenge. My problem presented itself years ago, prompting my search for answers. In full disclosure, I am a curator at the General George Patton Museum at Fort Knox, Kentucky and am a retired Army First Sergeant who spent over 20 years in the United States military, a fact that is addressed when describing my research methods in Part 2 of this study. On a conference call with several government officials who work for the Center of Military History $(\mathrm{CMH})$, the U.S. Army's organization charged with documenting the institution's history and heritage, and which manages a series of museums across the country, I was told, "we don't do museums about a single person." While reflecting on this statement, I began to wonder why this was CMH's stance and if that was such a good idea. After all, the Army did have a Patton Museum and maintained a collection of over 2,000 artifacts directly attributable to him. And it did have other museums dedicated to telling the stories of different subsets of the Army, some focusing on the individual experiences of soldiers, the history of particular units, and one dedicated to the lived experiences of women soldiers. It seemed to me then, as it does now, that there was a reason why decades ago, one year after Patton's death to be precise, the Army did "do" a museum centered on one of the most famous single individuals to ever serve this country. What, if anything, changed since then? Perhaps it was time for society to let go of the idea of the hero. Or 
maybe the idea of the hero is far more complicated than what detractors perceived it to be.

Not lost on me was the immense popularity of Patton's story. Countless times while walking through the galleries, veterans of World War II stopped me and exclaimed proudly, sometimes with a gleam in their eye, other times with tears, that during World War II they "fought with Patton" or years ago they were "one of Georgie's boys." I overheard parents explaining to their children and friends to their companions who Patton was and why he was, and is, important while recounting whatever tale they knew about him. How the keepers of Army heritage could not see the sway Patton had on American culture or missed the persistence of a collective memory (a term I was unfamiliar with at that point) within the Army's ranks was beyond my comprehension, at least at the time.

Although I did not know much about Patton when I began working there, after speaking with people who took a pilgrimage to the museum, I suspected that he was an American legend, a soldier placed firmly on a pedestal who reached almost godlike status for many. And I soon realized he holds a place in the pantheon of Army greats. What was unclear to me was how he got there and stayed for so many years. More recently, it also became clear to me that modern sentimentality seemed to be casting aside those like Patton. I was skeptical that was going to be good for our society, culture, and the individuals who operate within the Army subculture. Perhaps I was wrong, but I set out, with an open mind, to discover if what I witnessed was true. If Patton was in fact who I thought he might be, how he became so remained a mystery to me. I wanted to know if, why, and how he became a legend and if the Army could still use General George S. 
Patton, Jr. or any other military hero. I also wanted to know if heroes from all walks of life had any meaning for people today. This study is the result of that journey. 


\section{PART 1}

THE MAKING OF A HERO

\section{CHAPTER I}

\section{COMPETING NARRATIVES}

For, as I take it, Universal History, the history of what man has accomplished in this world, is at bottom the History of the Great Men who have worked here. Thomas Carlyle Americans love a winner. General George S. Patton, Jr.

This is not a biography of General George S. Patton, Jr. nor is it an historical analysis of his military career. Rather, this is an examination of the legends and myths surrounding the memory of him that constitute a collective historical memory and what that memory may mean for society at large and in particular the United States Army. It is a study of how things were remembered to have happened versus how events actually unfolded, a cultural history as well as a sociological examination of a subculture. As such, it assumes the reader has some contextual biographical and historical knowledge of Patton. Why study the collective memory of General George S. Patton, Jr.? For ages, hero mythology retained a firm grip on the human imagination. The American transcendentalist philosopher Ralph Waldo Emerson argued that "It is natural to believe in great men" and that "the search after the great is the dream of youth, and the most serious occupation of manhood."1 Scottish philosopher Thomas Carlyle understood too, "that great men, taken up in any way, are profitable company. We cannot look, however

\footnotetext{
${ }^{1}$ Ralph Waldo Emerson, Representative Men (Lexington, KY2016), 1.
} 
imperfectly, upon a great man, without gaining something by him."2 In a field of authors crowded with academics, military history buffs, populist biographers, and enthusiasts, is there much more that can be said about General George S. Patton, Jr.? Although a handful of definitive historical and biological works on Patton exist, none comprehensively address the history of the public forms of memorialization regarding him, why his story matters to so many people, how his story may be of use today, or why the legend should be perpetuated at all. Skeptics may find the modest return of a "great man" theory threatening in today's political climate. But, as will be demonstrated, certain subcultures still have a strong desire for heroes and, I would argue, so does our society by extension.

Certain individuals such as Patton became archetypical heroes, icons, symbols, and above all else, galvanizing social forces. He was demonstrably America's greatest general, at least in popular conception, according to a Gallup poll released in $2000 .^{3}$ Once known mostly for his sweeping victories in World War II on the battlefields of Western Europe, no other general in American history captured the public's imagination like him. After his death, the U.S. Army and the public lionized, institutionalized, then canonized Patton, and continued to use his story in various ways that serves as part of the story of how Patton came to be the legend he is. Yet this examination is not merely of the legend and legacy of Patton; in a broader sense it also illustrates how Americans used hero stories in a number of ways in the past, suggests how evolved narratives may keep

\footnotetext{
${ }^{2}$ Thomas Carlyle, On Heroes, Hero Worship, and the Heroic in History (Lexington, KY: Another Leaf Press, 2012), 5.

${ }^{3}$ Gallup, "Greatest American Military General of All Time? Public Says Patton, Eisenhower and MacArthur," Gallup, http://www.gallup.com/poll/2236/greatest-american-military-general-all-time-publicsays-patton.aspx.
} 
heroes of the past relevant in the modern world, particularly within institutions that utilize deliberate transformational processes, and illuminates certain aspects of American culture and psyche, especially within the military subculture.

The study centers on three questions: 1) How and why did the Patton legend develop into a collective and public memory, 2) What is the legacy he left for the U.S. Army, and 3) How might the Army's inclusion of Patton in its history and heritage programs be beneficial to the institution? The Patton legend was a deliberate undertaking that became a collective and public memory steeped in myth, which ultimately became part of his legacy for the Army. That collective memory serves as a potential source of personal inspiration and development, identity affirmation, esprit de corps, and social solidarity in the Army's transformational process for new members.

The recent rise of memory studies have not been accompanied by methodological advances in the research of collective memory processes, as historian Wulf Kansteiner pointed out. Most studies on memory focus on the historical representation of specific events, particularly with public memory sites, without reflecting on the audiences that those representations target. As such, insights into past and present historical cultures cannot be linked conclusively to specific social collectives and their historical consciousness while solely using historical research methods. ${ }^{4}$ There is an inherent problem that remains unresolved in memory studies: it is difficult to tie projected narratives of memory, such as those seen in dark tourism sites (places or experiences associated with death and suffering such as war memorials or cemeteries), museums, public forms of memory, commemorations, and films to reception, the internalization into

\footnotetext{
${ }^{4}$ Wulf Kansteiner, "Finding Meaning in Memory: A Methodological Critique of Collective Memory Studies," History and Theory 41, no. 2 (2002): 179.
} 
the collective consciousness of a particular group the narratives people are exposed to during visitations and interactions with public memory sites. ${ }^{5}$ Although Kansteiner promoted the use of communications and media studies methodology to reconcile this issue, I argue that qualitative sociological methodologies and theoretical frameworks provide more useful tools to understand the reception of projections, especially when trying to understand a specific subculture. Collective memory, as sociologist Maurice Halbwachs pointed out, is not a given but a socially constructed notion. Memory can only function within a collective context, a context that can be evoked by, for instance, war memorials or socially significant anniversaries, family reminiscences, or accounts of significant events in the past of a group or population of people. ${ }^{6}$

This work addresses the projection/reception problem head on and is comprised of two parts. Part 1, which consists of chapters one through seven, focuses on projection of the Patton legend in the early stages with a heavy reliance on empirical evidence of the traces of a public and collective memory of Patton, as well as a discussion on the impact Patton had on the U.S. Army. Evidence of the evolution of projections abounds. For example, newspaper and magazine articles from World War II that promulgated the Patton legend, as well as Patton's own efforts to reinforce that narrative by crafting a personal brand, are evidence of projection. After his death, various forms of public memory projects such as commemorations, memorials, dedications, monuments, statues, museums, toys, books, video games, movies, and cartoons kept Patton alive in collective memory in both intentional and unintentional ways. An examination of an eclectic mix

\footnotetext{
${ }^{5}$ Philip Stone and Richard Sharpley, "Consuming Dark Tourism: A Thanatological Perspective," Annals of Tourism Research, 35, no. 2 (2008): 574-595.

${ }^{6}$ Maurice Halbwachs, On Collective Memory (Chicago: University of Chicago Press, 1992). Halbwachs' seminal work on the sociology of collective memory will serve as one of the foundations of this study.
} 
of projections of a collective and public memory places the final chapter in Part 1, an examination of the Army subculture's utilization of the Patton legacy and heritage, particularly with doctrinal development, in context. Part 2 begins by defining the Army as a subculture and outlining the importance of heroes in a cultural framework. Chapter $\mathrm{X}$ details an examination of hero narrative usage by individuals who are undergoing a transformational process as they become full members of the Army subculture and suggests how Patton's story may still be of use by that institution. All of this, in turn, frames a grounded theory on how institutional hero stories might remain useful for organizations that utilize transformational processes to socialize future members.

Just because there are public memory sites around the world dedicated to Patton does not necessarily mean anyone internalized the narrative. While multiple newspaper articles, populist books, and films projected a certain hero story, these do not provide evidence of a collective memory, just a series of projections. In other words, the number of visitors to sites of leisure, tickets sold, or ratings tells us only how many people had an experience but nothing about how they experienced it or if they received an intended message. By utilizing sociological research methods to measure reception of the narrative, the underlying problem of memory studies, and acknowledging Halbwach's notion that memories are produced and maintained within a social context, the latter half of this work describes what the collective memory of Patton is today within the Army ranks and addresses how future leaders of the institution may find those narratives useful. After first establishing what the projections of the Patton legend and legacy were, a qualitative analysis of interviews with aspiring members of the Army undergoing a transformational process reveals the collective memory of Patton within the context of a 
broader culture and provides insights into how that collective memory may have changed over time.

While sociologists may be more overt in their application of theory, their study of human social life is not entirely distinct from the work of historians. Sociologists investigate past society, to be sure, but it is the present-centeredness of sociology that distinguishes it as a discipline from that of history. Sociologists attempt to establish general patterns whereas historians concern themselves with the interpretation of particular events, yet these two approaches need not be mutually exclusive, as this study demonstrates. $^{7}$

Because memory studies, like all historicism, uses a specialized language not familiar to everyone, definitions of some terms used throughout this examination is the logical place to start. First, the delineation between memory and history is important. Memory is not history but it has a history. Memory is clotted with sentiment, with retrospective distortion that people inflict upon the past. History, unlike memory, gives us a view of the past as seen through the eyes, hearts, and minds of the people who lived during a particular time. Memory, on the other hand, gives us a view of the past seen through the eyes of the present. Memory is also an indispensable prerequisite for the establishment of collective identity and for enjoying the solace of knowing the collective's past trials and tribulations, markers of a group's heritage. ${ }^{8}$ When people look to the past when trying to understand the present, the general postulate is more important to them. Groups of people have common memories that help frame their identity, often

\footnotetext{
${ }^{7}$ Peter Lambert and Phillipp Schofield, ed. Making History: An Introduction to the History and Practices of a Discipline (New York: Routledge, 2004), 122.

${ }^{8}$ Kendall R. Phillips, ed. Framing Public Memory (Tuscaloosa: University of Alabama Press, 2004), 101, 06.
} 
national or familial, and a sense of patriotism or belonging, but the manner in which many people use discussions about historical issues as a means of political debate is often flawed, misrepresented, or misunderstood. However, that is not what is important to historical memory. What is salient is there is a need amongst people to explain things with reference to a common, or collective, memory, as historically inaccurate as it may be. So, what is meant by the term "collective memory" and why is it important?

Answering this question necessitates an examination of the work of sociologist Maurice Halbwachs, an early twentieth-century theorist who argued that people came to understand the past through symbols, ritualism, historiography, and biography. His theories centered on class consciousness in accordance with Emile Durkheim's theories on collective representations and the ways in which people classify themselves. ${ }^{9}$ There is a hierarchy of class positions, albeit a synthetic one, in any modern society and at each rank in these hierarchies people look at the world through different lenses, have different patterns of consumption, and follow distinctive behavioral patterns. By emphasizing consumption as the most salient aspect of class formation, Halbwachs' definition and treatment of classes is somewhat closer to Max Weber's notion of status group and Thorstein Veblen's work on consumption-based classes than to either Karl Marx's or Max Weber's notions of class. ${ }^{10}$ His orientation in regard to class structure centered on occupations and individual behavior and lifestyle. His work on collective memory was path breaking and will have a continued impact on memory studies such as this one. ${ }^{11}$

\footnotetext{
${ }^{9}$ Emile Durkheim. The Division of Labor in Society (New York: Free Press, 2014).

${ }^{10}$ H.H. Gerth and C. Wright Mills, eds. From Max Weber: Essays in Sociology (New York: Oxford University Press, 1946) 180-195; see also "Alienation and Social Classes" in Robert C. Tucker, ed. The Marx-Engels Reader (New York: W.W. Norton \& Company, 1978) 133-135. For Veblen's work on "conspicuous consumption" and "conspicuous leisure" see Thorstein Veblen. The Theory of the Leisure Class (New York: Penguin Books, 1994).

${ }^{11}$ Halbwachs, 2-3, 19, 21.
} 
Most importantly, Halbwachs was arguably the first sociologist to assert that conceptions of the past are affected by the mental images employed to solve present problems, making collective memory a shared reconstruction of the past based on common conceptions of the present. Memory needs continuous feeding from collective sources and is sustained by social props. The same can be said of history in that it is made of continuity as well as change. In other words, the "present generation may rewrite history but it does not write it on a blank page."12

The term "collective memory" does not suggest that a consensus on any particular accepted narrative may be assumed. Any agreement implied within the term is the ideal that memory workers (those stakeholders who create forms of public memory or promulgate agenda-based narratives) aspire to and struggle for, not the natural result of historical experience. While individuals tend to remember events differently, collective memory is a product of the process of striving to achieve a consensus by those seeking to secure a broadly accepted public articulation of the past. Collective memory, then, is a precious resource "for maintaining social bonds and claiming authority, for mobilizing action and legitimizing it." ${ }^{13}$ But Halbwachs did assert that all acts of memory are inherently social, that is, to remember is to act as part of a collective and collectivity is intertwined with the capacity for and enactment of remembrance. ${ }^{14}$

People normally acquire their memories and recall, recognize, and localize memories within a societal context, not in a vacuum. To make his case about the social nature of memory, Halbwachs used a dialectic in which he compared memory to dreams.

\footnotetext{
${ }^{12}$ Ibid., 34.

${ }^{13}$ Iwona Irwin-Zarecka, Frames of Remembrance: The Dynamics of Collective Memory (New Brunswick, New Jersey: Tranaction Publishers, 1994), 67.

${ }^{14}$ Phillips, 1.
} 
The sphere of dreams, he argued, is an area in human experience that is not rooted in social context and structure: dreams possess characteristics that separate them from all other human experience in that they lack structure, continuity, orderly progression, and regularity. Memory itself, like dreams, has no organization, but memory conducted in the social sphere gives those concepts of the past structure. ${ }^{15}$ Yet, although an organization is important for the maintenance of collective memory, the characteristic of memory that matters most is that the collective believes a memory to be true. ${ }^{16}$

The past, memory, and history, although related, are not interchangeable concepts. This study defines the past as things that happened, collective memory as the subjective conceptualization of the past by a specific group of people (in this case Europeans, Americans, and members of the U.S. Army) that is not reducible to the concept of truth, and history as the objective understanding of the past based on facts and empirical (if not objective) truth. History and memory are opposing ways of recalling the past and assigning meaning, whereas history claims accuracy and objectivity and memory is conceived in terms of multiple, diverse, mutable, and competing accounts of past events. ${ }^{17}$

Collective memory can easily become too selective and mediated when compared to more empirical historical research on the same topic. The mythical structure of remembrance, its ideological bents, the emotional charge of symbols and disputes, and the obvious departure from objective facts do not necessarily take collective memory into a terrain of pure fiction, but rather necessitates a closer examination into truth and

\footnotetext{
${ }^{15}$ Halbwachs, 23.

${ }^{16}$ Irwin-Zarecka, 15.

${ }^{17}$ Phillips, 2.
} 
requires an appreciation for how those memories are framed, or how and why people remember (or forget) the things they do. The serious, mundane, sacred, dramatic, exotic, and commercial are all facets of remembrance and the ways they frame and communicate ideas need to be understood prior to examining what remembrance tells us about the past and present. How memory workers present the past, in other words, influences how the past becomes remembered. ${ }^{18}$

People do get upset when public memory (a term that will be defined later) is not faithful to their collective memory. Historians are granted special status, as they should, as being those with the strongest claims to the truth of what really happened. Ordinary people rarely challenge historians' academic authority except when a blatant misuse of authority occurs. If collective memory provides us with resources for making sense of the past, the empirical truth established by historians is added to by giving meaning to facts and figures. Making sense of the environment and finding meaning in existence are quintessential human phenomenon. They are processes of emotional classification, attaching feeling not only to ideas of the past, but to places, objects, and images which serve as memory markers, such as cemeteries, memorials, monuments, buildings, or structures from times long gone. The care to which countries and communities preserve and construct memory markers (sites intended to invoke memory) points to a shared recognition that our links with the past have to be supported and maintained in ways that give them permanency. At times these markers reach a status of the sacred. They allow for the enactment of rituals or commemorations that symbolize a shared past and sense of obligation to that past. These markers frame how people remember by drawing attention,

\footnotetext{
${ }^{18}$ Irwin-Zarecka, 145-46.
} 
invoking action, and inducing emotion while crystalizing them into symbols. They work as art does, representing the true meaning of the human experience. ${ }^{19}$

There is also a distinction between historical and autobiographical memory in that historical memory reaches the social actor only through records of the past kept alive through commemorations, festive enactments that reinforce the memory of events or people. Autobiographical memory is the memory of events that people personally experienced and serve to reinforce the bonds between participants. This type of memory tends to fade with time unless periodically reinforced through contact with persons with whom one shared the experience. Collective memory then can be stimulated in indirect ways through reading, listening, or participation in commemorations and festive occasions when people gather together to remember in common the deeds and accomplishments of long-departed members of the group. In this case, social institutions store and interpret the past. Present generations become conscious of themselves by counterpoising their present to their own construction of the past. Through participation in these commemorative meetings with group members of the current generation, people transfer a shared past that would otherwise slowly disappear with time. Collective memory fills the void between periods of effervescence and ordinary life. Ceremonies help perpetuate the recollection of great events of the past that hold communities together, and collective memory, as an intermediate variable, commemorates those events and is strengthened by them. ${ }^{20}$

For Halbwachs, the past was a social construction shaped by the concerns of the present. When understanding the dynamics of collective memory, the past and the work

\footnotetext{
${ }^{19}$ Ibid., 150-51.

${ }^{20}$ Halbwachs, 23-25.
} 
done on it must be kept in the foreground. History can be rewritten, politically manipulated, forgotten, embellished, or even fabricated. ${ }^{21}$ The beliefs, interests, and aspirations of the present shape the various views of the past as they are manifested respectively in every historical epoch. Memories are not possible outside the frameworks used by people living in society to determine and retrieve recollections of the past. The faraway world where people remember suffering, for instance, exercises an incomprehensive attraction to survivors who think the best parts of them were left behind while they try to recapture their former selves. Nostalgia, or "a wistful desire to return in thought or in fact to a former time," is a powerful and tempting force and further distorts history. ${ }^{22}$ The imagination reproduces the past to describe present social milieus and therefore is best understood as a contemplative or dreamlike memory that helps people escape the present world and think fondly of an imagined past. ${ }^{23}$

On the social nature of memories, Halbwachs posited that people are members of many different groups simultaneously, so the memory of the same fact can be placed within many frameworks that result from distinct collective memories. Individuals remember within the framework of a group's perspective and the group in turn affirms that the memory realizes and manifests itself in individual memories. It is a reciprocal relationship. Collective memory confines and binds the most intimate remembrances to each other but it is not necessary that the group be completely familiar with them. The group in itself has the capacity to remember and individual consciousness remains, in certain respects, impenetrable in regard to one another. People find themselves to be part

\footnotetext{
${ }^{21}$ Irwin-Zarecka, 17.

${ }^{22}$ Dictionary.com, s.v. "nostalgia," accessed September 17, 2020, https://www.dictionary.com/browse/nostalgia/.

${ }^{23}$ Halbwachs, 43, 49.
} 
of a group where their position is determined not by personal feelings but by rules and customs that existed in a collective before membership. For example, the expression of feelings is regulated through family structures and that structure is important for the group (family) to retain cohesion. The same can be said for Army units at the tribal level, such as a platoon or company (30-100 people). Each group has a particular mentality, memories that it commemorates, and secrets. Memories within these types of structures exist as a series of individual images of the past and express a general attitude of the group, reproduce its history, and define the nature of its qualities and weaknesses. In other words, memories help create identities that in turn provide frameworks for the perpetuation and preservation of memory. Memory may be viewed as a process within the framework of an organization with many figures and facts serving as landmarks or symbols that express its culture. ${ }^{24}$

Events remembered by collectives (groups that share common interests or objectives) consist of two characteristics. First, people recreate a singularly rich picture that is deeply penetrating since it allows group members to retrieve realities they came to know personally through experience. Secondly, it obliges members to view the past from the perspective of the group, that is, to recall the relationships that explain why the past is important to all members. The recollections of the group pervade the memory of one or several members through events and the shared assumptions and beliefs of the group but they are not entirely in a form of stasis: outside influences may become adopted into the group's set of traditions or transform those traditions. Within the framework of a collective the group is created of notions of persons and facts that are singular and

\footnotetext{
${ }^{24}$ Ibid., 52-55, 57, 61.
} 
historic and have all the characteristics of thoughts common to the whole group and even to several groups. Every organization ends up with its own logic and traditions, which resemble those of a broader institution. The role of tradition is to ensure the collective's cohesion and to guarantee its continuity. While the past cannot be reborn, groups of people can fathom what it was like before them and honor that past by emphasizing wellestablished landmarks that aid in the social solidarity of the organization. ${ }^{25}$ This is particularly true for military organizations.

Like Emile Durkheim, Halbwachs used religion as an example to illustrate the phenomenon of how collective memory works, paying particular attention to rites and commemorations. Durkheim wrote at length on the use of props that assure the continuity of collective memory between periods of assembly, but Halbwachs recognized those objects are not ever present. For Halbwachs, those periods between assemblies were nevertheless "filled and fed by collective memory," not only during ceremonies that helped members of a group recall great events or actors of the past. ${ }^{26}$ Beliefs are interpretations of meaning seen through rites and commemorations, or the changing nature of memory that conforms to present needs and concerns. While rites and rituals may be the most stable element that is continuously reproduced and assures uniformity in time and space, they correspond to the need to commemorate a memory. People tend to remain attached to formulas, symbols, conventions, and rites that they repeat and reproduce in order to preserve the beliefs of the group. Through this attachment to value

\footnotetext{
${ }^{25}$ Ibid., 71, 74, 83.

${ }^{26}$ Halbwachs, 25; For Durkheim's treatment on social props that aid in the perpetuation of collective memory, see Emile Durkheim and Karen Fields. The Elementary Forms of Religious Life (New York: Free Press, 1995).
} 
systems, the groups of yesterday, the present, and the future connect. ${ }^{27}$ In the case of religion, dogmas and rites are not purely rational and it is to the past that one must look to explain them. One explanation for the existence of religion is as means of survival for memory. "It is only the commemoration of events that terminated or sacred personalities who disappeared long ago" that keeps memory alive. ${ }^{28}$

We also cannot restrict our understanding of collective memory to examining the traces of historical knowledge or narratives. Emotion and moral arguments with the past also plays a part. The questions of how people recreate the past and why it matters must be answered. Defining entire historical eras as a task to be mastered is quite different than framing events, heroes, and places as worthy of remembrance and honor. Historiography is not all that matters - understanding why a collective remembers something is the key to unlocking how collective memory works. There are also subsequent questions of whom, to whom, for whom, when, where, and why. Rarely are these issues settled in public discourse because there are multiple meanings for different groups - different people care about their past in different ways and at different times. Collective memories are not constant - they change even within a community for two reasons. First, collective memory is related to a sense of collective identity that individuals acquire independently after aligning their personal goals and objectives with that of the group. Secondly, collective memory is imbued with moral imperatives, such as the obligations to one's kin, notions of justice, lessons of right and wrong, and other forms of the normative order. Collective memory is a significant orienting force,

\footnotetext{
${ }^{27}$ Halbwachs, 116, 20.
}

${ }^{28}$ Ibid., 178. 
something people need to understand their place in the world and to account for why people do what they do. ${ }^{29}$

The Army provides a compelling example. In the specific case of the military, when a war is over, the culture of a unit remains even though most of the original members were killed in action or replaced over time. This is a function of a group's heritage, traditions and belief systems passed on from generation to generation. Furthermore, "Despite intervals of peace there is what may be called a natural and historical species of soldiers. That is, there are certain common traits characterizing soldiers in all historical periods that can be explained in terms of the soldier's life in the trenches and camps and which only incidentally derives from military traditions." 30

Individuals recall the past by relying on the frameworks of collective memory. Groups reconstruct their past, but distort that past in the process of reconstructing it. Many facts and details would be forgotten if not for collective memory, to be sure, but the past is distorted because people introduce greater coherence. American sociologist Barry Schwartz called attention to the fact that if collective memory was not malleable, it would suggest that there is no continuity with history but would rather be a series of snapshots taken at various times that express various perspectives trapped in that time and place. However, the past is always a "compound of persistence and change, of continuity and newness." 31 Reason, intelligence, and emotion choose among the store of recollections and eliminates some of them and arranges others according to prevailing ideas at the moment. Memory is not only a collective function: it is a subjective one. ${ }^{32} \mathrm{~A}$

\footnotetext{
${ }^{29}$ Irwin-Zarecka, 7, 9.

${ }^{30}$ Halbwachs, 161.

31 Ibid., 26.

32 Ibid., 182-83.
} 
group's current perceived needs may compel it to refashion the past, but successive epochs are kept alive through a common code and a common symbolic canon even amidst contemporary revisions. ${ }^{33}$ Of course, this study examines one case in detail, that of the memory of General George S. Patton, Jr. While there was at one time entire series of rites and commemorations dedicated to the man as a means of remembrance, the institutionalization of his memory in the Army was a means of preserving the beliefs, values, and cohesion of the collective.

Experience also plays a role in the construction of memory. Many scholars of memory studies forget the cultural sensibilities and norms that inform the structure of remembrance. There are politics in memory, to be sure, but that is not all. A collective memory, that is, a set of ideas, images, and feelings about the past, is best located not only in the minds of individuals but also in the resources they share. In terms of those resources, there is no reason to privilege one over another - from an empirical perspective, all of them form evidence of a collective memory. While scholars will understandably give more credence to credible sources, this postulate does not necessarily hold true for the general public. And while some sources are more powerful than others, for collectives to remember, popular movies are just as important as history books, particularly with their ability to create emotional responses. Students of collective memory would do well to study empirically rather than solely theorizing to assess which resources matter to whom and to establish relationships between publicly articulated and privately held views of the past. Just because there are an abundance of resources does not guarantee that people use them or that there is a predominantly common

\footnotetext{
${ }^{33}$ Ibid., 26-27.
} 
understanding of the past. Likewise, just because there are "quality" sources does not mean that those narratives will become the generally accepted version. People can ignore the best arguments and stories, inject their own, and use ways of making sense that fit their own needs. Furthermore, public forms of memory, such as monuments, memorials, museums, and the like, all claim to tell the truth along with a claim on our attention. At a commemoration we are asked to remember, in magazine articles we are asked to reflect and inform ourselves. ${ }^{34}$ Historians' works and physical memory markers are two extremes of a continuum. What informs and forms our sense of the past is found in between - public story telling through television, film, novels, poems, biographies, autobiographies, theater productions, and commemoration ceremonies. Evidence of these types relating to Patton abound. If history is the objective form of remembrance, of which there are relatively few regarding Patton in comparison with other famous individuals, then memorials and the like represent the emotional, subjective frame of collective memory. ${ }^{35}$

Social beliefs have a double character in that they are both collective traditions or recollections and ideas or conventions formed from knowledge of the present. If collective memory were conventional or utilitarian, social thought would be logical. But it is not. If society was purely traditional it would not allow itself to be permeated by new ideas that disagreed with the oldest beliefs. But it does. Social thought is not merely an abstraction - it does not simply float around in the ether but has real-world consequences that becomes manifest through action. The "ideas of society are always embodied in persons or groups" and are essentially memories in which its entire content

\footnotetext{
${ }^{34}$ Irwin-Zarecka, 4.

${ }^{35}$ Ibid., 151.
} 
consists only of collective recollections or remembrances. The only collective memories that can exist are the ones that can be reconstructed and concrete forms of those memories aid in reconstruction. ${ }^{36}$ Society immediately perceives those who embody commonly valued virtues or qualities and who leave traces in the memory of people, especially if they share a common past with that society. There is no social idea that is not also a social recollection. When historic people and facts permeate memory, it translates into a teaching, a notion, or a symbol that takes on meaning. Often those symbols that represent social thought in the form of collective memory take concrete form, are acted out, or become performative. They become an element of a group's system of ideas. This explains why traditions and present-day ideas exist simultaneously and are visible. ${ }^{37}$ Over time, the collective memory of Patton continued to exist and evolve, indicating its importance.

Like memory, legend is a departure from history: it is a cultural representation of the past that implies a fictitious tale, "the product of folk imagination." 38 The concept of legend attempts to mediate between history and that imagination. Once fabricated elements are identified, the narrative loses is status as an historical account and moves into the field of legend. Yet, the line between history and legend is not always consistent or clear. While history and legend both rely on narratives, legend effects the creation of history and history effects the creation of legends. This interplay reveals the transformative character of collective memory and its susceptibility to conflicting views

\footnotetext{
${ }^{36}$ Halbwachs, 189.

${ }^{37}$ Ibid., 188.

${ }^{38}$ John R. Gillis, ed. Commemoration: The Politics of National Identity (Princeton, NJ: Princeton University Press, 1996), 105.
} 
that turn the past into a contested arena. ${ }^{39}$ Because of their similarity, legend and memory will be used interchangeably throughout this study. Referring to Patton as a legend or the legend of Patton is a heuristic way of singling him out and designating an attitude of veneration for him. Therefore, the Patton legend, as will be demonstrated, is the collective memory. This does not mean that history does not play a role in the legend. Much of the legend is wrapped up in history, meaning it is objectively true in historical terms. History and legend are complimentary in the commemorative process. The term "legend" can articulate a belief in Patton's historical value, and therefore the process of becoming a legend becomes a means of guaranteeing the place of this person in the collective memory of society. At the same time the term can be accusatory, assuming an adversarial relationship to history. Although classification as a legend appears to focus on the issue of validity, it in fact revolves around the question of credibility. As long as members of a collective accept the collective memory as credible, historical validity does not matter much for its utility for the collective. But when the symbolic message loses its credibility, even an historian cannot dispel persuasive doubts about its historical foundation. Historical narratives become legend by popular vote and credibility reflects the social attitude towards the narrative. ${ }^{40}$

Collective memory offers an anchor of continuity and identity for collectives, but it only serves as one force that bonds people together. Values, common ways of doing things, goals, aspirations, fears, and ties of kinship can draw strength from collective memory. Along with collective memory, they are parts of culture. ${ }^{41}$

\footnotetext{
${ }^{39}$ Ibid., $105,118$.

${ }^{40}$ Ibid., 117.

${ }^{41}$ Irwin-Zarecka, 92.
} 
What are the qualities attributed to Patton that caused him to become a legend that society and the Army strove to keep alive in collective memory and how have those changed to fit the needs of the time? What does this tell us about broader society's concerns at those points in time that coincide with changing paradigms? What is it that makes people who share communal bonds and boundaries with distinct visions care so much about their heroes? The following chapters seek to answer these questions.

The Patton legend, which later became the collective memory of him, began with Patton himself. The creation of George S. Patton's personal brand is where the collective memory began. 


\section{CHAPTER II}

\section{A LIVING LEGEND}

Remember that your primary mission as a leader is to see with your own eyes and to be seen by the troops when engaged in personal reconnaissance. Patton's Letter of Instruction to All Commanders, Third U.S. Army

There are two interrelated ideas that are necessary to understand as simultaneous phenomenon when approaching the history of memory regarding General George S.

Patton, Jr. First, the creation of the Patton legend and the perpetuation of a certain collective memory were deliberate acts. The underlying assumption behind this notion is there were stakeholders in the creation of the legend. Second, the Patton legend either influenced or actually became the Patton legacy. The legend, a creation of Patton himself and the World War II-era media, became embedded in public consciousness through forms of public memory and transformed into a collective memory, seen today in various aspects of American society, and in particular U.S. Army culture. Years after his death, Patton's nephew poetically described this memory, one mirrored in both earlier and recent publications:

Those who choose to can of course remember what he looked like toward the end: in an almost larger than life-size pose, standing very tall, chin and chest outthrust, pistols at hips on a broad leather, specially made belt cinching in the waist of his Eisenhower jacket. They can remember, possibly, views of him with head emerging from the turret of a tank; or standing dramatically to survey a battlefield through upraised binoculars. Or they may retain a vision of a bright splash of ribbons across the tunic's breast, plus a helmet burnished and lacquered beyond brightness carrying one, two, three, and, finally, four silver stars. Certainly those who remember at all can see an almost arrogantly erect figure, an aura of showmanship, a display of strength, possibly more than a hint of brutality or heartlessness. This was his public image, which gave rise to such sobriquets as the "Green Hornet," and "Old Blood and Guts...." What I would like to suggest is that George Patton finally succeeded in creating a man in his own image of himself, and that he 
both profited and suffered from his own handiwork. This had to be so since, in the long run, the outward show to a great degree belied the truth. ${ }^{42}$

Patton's stagecraft, news sources, and those hoping to keep his memory alive through the use of branding, hero narratives, popular culture, and forms of public memory helped create and perpetuate the legend. Why each of these actors did so were for various and unrelated reasons, but regardless of the intent, these motives require uncovering through deductive and inductive reasoning in order to understand the staying power of Patton's story in collective memory. While some motives for the creation and perpetuation of the legend are obvious, many are unclear.

The Patton legend began with Patton himself. He carefully crafted an iconic brand over the course of his career, fashioning himself after classical military heroes. His personal brand was flamboyant, easily recognizable, and audacious. As told by Patton's personal secretary, "Patton went to war with the shining paraphernalia of the born martinet; with helmet polished, his four stars aglow," and his "pearly pistols displayed for all to see." ${ }^{\text {43 }}$ It encompassed everything from his dress to his mannerisms, including a constantly practiced "war face" to mask his self-perceived weak jawline and the use of crass language to cover his high-pitched voice with its hint of a Southern aristocratic accent. ${ }^{44}$ As a public figure, who really came to the public's attention first during the Punitive Expedition in 1916 when he led an attack that killed several key officers in Poncho Villa's command structure, he understood the value of popularity and was keen on how creating a brand would help keep him in the public's eye. Harry Semmes, a former subordinate commander under Patton during both world wars wrote,

\footnotetext{
${ }^{42}$ Frederick Ayer, Before the Colors Fade: A Portrait of a Soldier (Boston, MA: Houghton Mifflin, 1964), 53-54.

${ }^{43}$ Joseph D. Rosevich, "The Patton Nobody Knows," SAGA, April 1953.

${ }^{44}$ Ayer, 55, 56.
} 
He always dressed immaculately and expensively. His combination [of] riding breeches and jodhpurs, with a specially made English combat boot, were distinctive. His famous glistening helmet liner was the result of literally dozens of coats of varnish by ordnance personnel. Around this shining halo were the insignias of all his former commands, like a garish chaplet. When he traveled he carried an arsenal of guns and an extensive wardrobe in several traveling bags, packed by his loyal Negro orderly, Sergeant George Meeks.

Patton always took care to dress well, and presented a dashing figure. He also knew that he must be confident in his own plans and his subordinates' capabilities, or at least appear to be so, in order to instill that same sense of assuredness in his junior officers. ${ }^{45}$ His colorful flamboyance, rough language, and unique style of dress were well-calculated mannerisms intended to serve a specific function: the creation of a warrior model meant to inspire his men. ${ }^{46}$

In his "Letter of Instruction Number One" to his subordinate commanders, Patton directed leaders to conduct in-person reconnaissance and observation of the front lines for two reasons: first, to see the battlefield with their own eyes, but of equal import, their other mission as a leader was to "be seen by the troops" while there. He gave the same order in regards to visiting the wounded in hospitals. ${ }^{47}$ In his second letter of instruction, Patton reemphasized that troops entering combat for the first time required "aggressive leadership by all grades, including general officers who must be seen in the front line during action." ${ }^{\text {48 }}$ Adamant about being visible to his soldiers, Patton warned his officers that it was always best, where practical, to drive to the font so as to be seen moving in that direction and then fly back in a small airplane so as not to be seen moving towards the rear and away from immediate harm, a personal practice of his during World War II.

\footnotetext{
${ }^{45}$ Harry Hodges Semmes, Portrait of Patton (New York: Appleton-Century-Crofts, 1955), 13, 206.

${ }^{46}$ Edward Tabor Linenthal, Changing Images of the Warrior Hero in America: A History of Popular Symbolism (New York: E. Mellen, 1982), 34.

${ }^{47}$ Jr. General George S. Patton, "Letter of Instruction No. 1," in Military Essays and Articles (The General George Patton Museum, 1944).

${ }^{48}$ General George S. Patton, "Letter of Instruction No. 2," in Military Essays and Articles (The General George Patton Museum, 1944).
} 
Moreover, Patton believed that a "leader must be an actor. He is unconvincing unless he lives the part." Inspiration, he asserted, "does not come via coded messages, but by visible personality" and that "the more senior the officer, the more time he has to go to the front. ${ }^{\prime 49}$ During his speeches, he used the crass language of the common soldier in order to be more relatable to them. In his view, he could "never get anything across unless we talk the language of the people we were trying to instruct. Perhaps that is why I curse." $" 50$

This aspect of Patton's self-crafted image was not lost on those who knew him intimately. The wife of one of his subordinate officers of whom Patton held in high regard, Colonel Harry Flint, recalled after Patton's death,

I have always had the conviction that the "Blood and Guts" manner, the tough talking, was really a sort of "Whistling in the Dark" which he had from the very first contrived to serve as a kind of apparatus to build himself into the person he wanted to be as a soldier; that he thought a soldier had to be strong, physically, mentally, morally, (and he was all these); that he believed a soldier should be unmoved by fear, suffering, the sight of death, blood, any horrible or vile thing; that he must endure. This, it has always seemed to me, was the motivation back of all the rough, profane, and at times almost vulgar manner and speech. ${ }^{51}$

Those close to Patton knew a different man, who behind the scenes was a kind-hearted, jovial prankster, oscillating between that and a cerebral intellect and introspective thinker. He was a complicated and interesting individual to many.

The Patton brand worked as designed. The defining feature of military uniforms is that they all look the same. When the intent is for everyone to look alike, standing out in a crowd is frowned upon. Many soldiers on the front lines during World War II recalled the times when they saw Patton make an appearance, noting his manner of dress as the distinguishing feature. For example, Loren Evans of the $1^{\text {st }}$ Ranger Battalion

\footnotetext{
49 "Patton's Best Quotes," in Military Essays and Articles (The General George Patton Museum).

${ }^{50}$ Ibid., 261.

${ }^{51}$ Semmes, 188.
} 
recalled seeing Patton during the invasion of Sicily on the beaches near Gela, specifically noting the "pearl [ivory]-handled revolvers and shiny boots. Spit and polish." ${ }^{52}$ Robert L. Orbach, a junior artillery officer, reminisced about the time he met Patton during a river crossing. Shocked to see Patton rush over to where he stood, Orbach remembered Patton wore "the pearl [ivory]-handled pistols, shiny helmet and the riding boots that made him such a fearsome sight" as Patton yelled at him to "Get those damned tanks out of the way, have that truck moved, get those men moving that way,"” and other instructions punctuated with his customary expletives. ${ }^{53}$ When Patton visited the $95^{\text {th }}$ Infantry Division during mid-1944, Carl Ulsaker, another junior officer, lamented that he was unable to see the ivory-handled pistols or resplendent uniform, which Patton wore under an overcoat that day. ${ }^{54}$ Nat Frankel of the $4^{\text {th }}$ Armored Division recalled the time his tank became mired in the mud in an intersection during the race to Bastogne during the Battle of the Bulge. Frankel stuck his head out of the tank's turret, looked around and saw Patton. "The first thing I saw was those two damn guns of his. Ivory-handled, not pearl," they were "strapped across his hips like a portable totem pole." 55 Appearance was key to Patton's concept of effective combat leadership. It is essential, he wrote, that "a general have a soldierly bearing and typify in his person, as well as possess in his mind, the highest qualities of a solder. Such a presence goes very far towards winning the confidence and respect of the men and the example of a soldierly appearing general is followed with minute exactness in the appearance of the officers and

\footnotetext{
${ }^{52}$ D.A. Lande, I Was With Patton: First Person Accounts of WWII in George S. Patton's Command (St. Paul, MN: MBI Publishing Co., 2002), 46.

${ }^{53}$ Robert Orbach, Not All Hell: Two Hundred Sixty-Five Days in General George Patton's Third Army (Tulsa, OK: Out on A Limb Publishing, 2003), 103.

${ }^{54}$ Lande, 114.

${ }^{55}$ Nat Frankel and Larry Smith, Patton's Best: An Informal History of the 4th Armored Division (New York: Hawthorn Books, 1978), 41.
} 
men of the command." ${ }^{56}$ Patton had a calculated and practiced public persona, and a select few had the opportunity to witness the rehearsals. Private Joseph Rosevich, to whom Patton dictated nearly every piece of correspondence over the course of World War II, related the development of the infamous "Blood and Guts" speech. Rosevich was "dazed by the contrast between the contents of the speech and the cultured, quiet poise of the man who created it," a man he described more as an intellectual who reminded him of President Woodrow Wilson. Patton explained to Rosevich that the performance he and others witnessed was exactly that: a performance, a "put-up show, a calculated and rehearsed act of bravado" that Patton viewed as a necessity to toughen up a generation of soft and carefree American men. "For the last twenty years," Patton complained, "our boys have been subjected to a steady diet of pacifist talk and doctrine. Now all of a sudden these 'pacifists' have to be turned into soldiers thirsting to kill the skilled, battletested soldiers of a shrewd enemy." Finding himself in a "perfectly ridiculous" situation in which Patton felt he must shock these men out of their mental habits, he opted to use the crude vernacular of the common soldier in his speeches to accompany his crafted image. ${ }^{57}$

As evidenced first by the way he dressed, Patton had a flair for the dramatic. He wrote to one of his subordinate Generals regarding his appearance, stating, "I want the men of the Third Army to know where I am, and that I risk the same dangers that they do. A little fancy dress is added to help maintain the leadership and fighting spirit that I

\footnotetext{
${ }^{56} \mathrm{Jr}$. George S. Patton, "War As She Is," in Military Essays and Articles (The General George Patton Museum, 1919).

${ }^{57}$ Rosevich, 26.
} 
desire in the Third Army." 58 Of course, if it was paramount for leaders to be seen at the front, then it stands to reason why he had a uniform that was easily identifiable. Adorned in a polished helmet liner, tailored waist-length jacket, jodhpur riding breeches, English saddle leather pistol holster and belt, spit-shined knee-high tanker boots, and carrying an ivory-handled revolver and riding crop, General George S. Patton, Jr. strode into the imagination of many Americans and into history and memory. Nothing he wore, like much of what he said and how he said it, was conventional for his time - no other American general spoke or looked like him, nor have many since. Every bit the combination of horse cavalryman and tanker, Patton looked the part with accouterments and accessories that symbolized both: his peculiar uniform matched the ideal he had for the romantic warrior and the amalgamation of a cavalry trooper and armor soldier. However, this public persona came at a cost. His long-time aide-de-camp, Al Stiller, wrote that he never saw anything in print that captured the "truly great stature of General Patton," rather what was widely accepted was the "flamboyant hell-for-leather, here goes nothing picture of him, which he himself presented many times for the benefit of the troops - and very effectively too. This was simply an act, with a few facts, about individual combat, to imbue them with the spirit of combat [emphasis added]. ${ }^{59}$ Echoing this idea, Major General Robert Littlejohn, the Chief Quartermaster of the European Theater of Operations (ETO), once asked Patton about the purpose of his fancy regalia. Patton boldly claimed that he wanted the Germans to know his location. Littlejohn, as

\footnotetext{
${ }^{58}$ Quoted from a letter written in France in 1944 to Major General Robert M. Littlejohn from Patton and published in Milton F. Perry and Barbara W. Parke, Patton and His Pistols: The Favorite Side Arms of General George S. Patton, Jr (Harrisburg, Pennsylvania: Stackpole Co., 1957), v.

${ }^{59}$ Letter, Al C. Stiller to Milton F. Perry (General George Patton Museum, June 10, 1954).
} 
others did, concluded that Patton fitted his dress, actions, and the wearing of his pistols to best suit a specific occasion. ${ }^{60}$

For most of World War II, Patton wore a general officer's uniform prescribed for combat by the U.S. Army. However, the image that comes to mind for most Americans when they imagine Patton is that captured by George C. Scott's initial scene in the movie Patton (1970), and it was a version of this uniform that Patton wore to the front when he wanted his troops to see him there. The helmet liner was a typical second pattern olive drab U.S. M1 helmet liner. Made of pressed paper with ribbed cotton covering, the helmet liner was not designed to be protective alone, but rather served as a suspension system for the M1 steel helmet. It had a removable leather and cotton sweatband like any other. However, unlike any other, Patton ordered his personal aide to add several layers of olive drab paint with a final coat of clear lacquer. His long-time aide, Sergeant Meeks, polished the liner daily to ensure it had a high shine when worn. On the front, there were the four metal five-pointed stars of a General, but with a row of three and one above the others. Presumably, Patton wore the liner as a Lieutenant General (three stars) and added the fourth on top when promoted in April 1945. Below the stars, the helmet pictured the Third U.S. Army shoulder sleeve insignia (SSI), the iconic "A" inside in a circle. Painted on the proper right side of the liner are the SSI of the $2 \mathrm{~d}$ Armored Division and the I Armor Corps, both of which Patton commanded from 1941 to 1943. Painted on the proper left are the $7^{\text {th }}$ U.S. Army and II Corps SSIs. Today, the lacquer is bubbled due to heat from a fire at the Patton estate in the early 1980s. Records demonstrate that the liner now at the General George Patton Museum is the "signature liner" he wore throughout

${ }^{60}$ Letter, Robert M. Littlejohn to Milton F. Perry (General George Patton Museum, April 2, 1954). 
the war and believed to be that which he wore under his steel helmet. First given its shiny appearance on November 15, 1944, the unit insignia were added 13 days later. ${ }^{61}$

Patton's Ike jacket was typical for the time, with a couple of exceptions. General Dwight Eisenhower considered the issued uniform to be too restrictive for combat and had his tailor modify a Wool Field Jacket Model 1944, specifying that the jacket was to be short and comfortable. By November 1944, Eisenhower's design became so popular that it became standard issue for U.S. troops and thereby commonly known as the Ike jacket. While intended for use in combat, most soldiers preferred to wear it in noncombat situations. As was the case with Eisenhower, when Patton first began wearing his, the Ike jacket was considered non-regulation, much like the rest of his combat wardrobe. The ribbons that Patton chose to wear on his jacket were also non-regulation in that he wore them not in the prescribed order of precedence, but instead wore his ribbons in order of personal preference. Those he personally valued most, although not necessarily as prestigious as the others, he placed ahead of ribbons of a higher order. Patton's flair for the dramatic extended to his rank devices, the visible representation of his place in the military hierarchy. The general officer stars that indicated his rank were larger than those issued by the Army and at least one set was made of pure silver. Larger was more visible for the frontline troops and therefore seemingly more desirable for him. Army officers purchase their own uniforms today just as they did in World War II. Civilian tailors made uniforms that met certain specifications for uniformity purposes. Patton, a man of wealth and means, solicited the finest tailors available. For example, the breeches he wore that are most associated with his public image are jodhpur riding pants,

${ }^{61}$ Artifact File CCN 462149, (The General George Patton Museum). 
which the Army stopped issuing prior to World War II, tailored by Bernard Weatherhill, Itd., a London fine clothier based in Piccadilly Square, in April 1945. They were olive drab, flared-seam horse riding breeches of wool elastique with two side and one right rear pockets. The tailor even typed Patton's name on the laundry tag. ${ }^{62}$ Not only had the Army phased out this uniform item, the Army no longer used horse cavalry. However, Patton wanted to project the image of the romantic cavalryman, and so wore these breeches to remind those who saw him of his cavalry roots.

Much the same can be said of the boots Patton wore. After major combat operations in Europe were over, Patton had time to settle in at his headquarters in Bavaria. He ordered a member of his staff to find the best cobbler in Germany to replace his worn out boots and make a new dog collar for his pet bull terrier, Willie. The footwear made for Patton were a unique combination of strapped tanker and cavalry riding boots, further mirroring his unique background as a cavalryman and tank commander. Made of the finest russet brown leather, Sergeant Meeks polished the boots to a high shine. These were the boots Patton wore during the bond drive tour he participated in during 1945 where photographers captured and distributed hundreds of pictures of him, further embedding the Patton brand in the minds of many Americans.

Another icon of the cavalryman persona Patton used as part of his brand was something he carried. Rather than a swagger stick, a military symbol of authority, Patton typically augmented his image with a horse-riding crop (although he did carry a specially made swagger stick for Operation Torch) even though he was only known to ride a horse

${ }^{62}$ Artifact File CCN 457025, (The General George Patton Museum). 
once during his time in the ETO when he rescued the Lipizzaner show horses. The Army disbanded the last horse cavalry units in April 1942.

Without a doubt, the most commonly cited aspects of the Patton brand were his revolvers. Often mistaken as being twin pearl-handled pistols, even by those close to him, Patton's famous revolvers were in fact very different. One was a single action, .45 caliber Model 1873 Colt "Peacemaker" while the other was a double action, 1936 model .357 caliber Magnum made by Smith and Wesson. ${ }^{63}$ As an example of the common misconception, a longtime friend of Patton exclaimed he was "first and foremost an exhibitionist. He played to the galleries. His dress and pearl-handled guns were largely stage props that became his trademark in the public mind." ${ }^{\prime 4}$ As stated previously, Patton's brand was meant to be more than a means of bringing attention to himself in the media; while at the front he wanted to be seen so that his soldiers knew he was willing to risk danger and share in hardships. Major General Paul Harkins, the Third U.S. Army Deputy Chief of Staff, described his impressions he garnered while serving on Patton's staff throughout World War II. "When General Patton went to the front, he usually wore one of the ivory-handled pistols [the Colt Peace Maker].” At times, he carried an issued small .32 caliber Colt automatic pistol while at his headquarters, and the only known time that he carried both revolvers was during Operation Torch, the amphibious assault landing he led in 1942 in North Africa, where both weapons, holster, and belt were nearly dumped into the ocean when naval artillery rocked Patton's landing craft as sailors lowered the small boat into the water. The "two-gun" image of Patton is largely "a

\footnotetext{
${ }^{63}$ Artifact File CCN 455980, (The General George Patton Museum). Artifact File CCN 455981, (The General George Patton Museum).

${ }^{64}$ Semmes, 15.
} 
creation of some inventive reporter" who capitalized on Patton's carefully crafted brand, a claim that Patton never refuted. ${ }^{65}$ Patton understood the power of the press and was hesitant to dispute the legend building around him. However, it did have its drawbacks. "Well," Patton stated, "I'm not sure whether some of it isn't my own damned fault, but, however that may be, the press and others have built up a picture of me. So now, no matter how tired, or discouraged, or even really ill I may be, if I don't live up to that picture my men are going to say, 'The old man's sick, the old son-of-a-bitch has had it.' Then their own confidence, their own morale, with take a big drop." ${ }^{96}$ Patton preferred carrying the revolver because "there was less chance of its jamming," but it was highly unlikely that he would ever need to fire it. It was an archaic weapon on a modern battlefield but as a symbol it was indisputably powerful. ${ }^{67}$

The Colt was an "outward manifestation of a dynamic character and became so intimately associated with his name that pictures of him without it seem bare indeed." It was "probably the best known pistol in America" at the time, and arguably remains one of the most famous, and was perhaps "the most important link of the Patton Legend." Considered a piece of Americana by many, the Colt Peacemaker could not have been a better choice for Patton, a legend in his own right, even if he never intended for it to become the powerful symbol it ultimately turned into. Arguably, the twin symbols of Americanism illustrated in Patton and the famous sidearm came to represent the idealized version many Americans held for themselves. Patton purposefully crafted a picture of himself, which he "presented many times for the benefit of the troops, and very

\footnotetext{
65 "The General's Personal Sidearms," http://www.pattonhq.com/unkown/chap05.html. ${ }^{66}$ Ayer, 203.

${ }^{67}$ Letter, Milton F. Perry from Major General Paul D. Harkins, April 8, 1954 as quoted in Perry and Parke, 92.
} 
effectively too. This was simply an act" orchestrated to "imbue them with the spirit of combat." ${ }^{68}$ Patton only carried the revolver when visiting troops on the front lines. ${ }^{69}$ Often referred to as "a thing of beauty," the Peacemaker was a symbol on a symbol. It was the thing that stood out more than any other part of his brand. ${ }^{70}$ To many, it was the revolver that made Patton recognizable more than any other. One such individual who served under Patton in World War II lambasted Martin Blumenson, who edited Patton's Papers, when Blumenson incorrectly described Patton's "pearl-handled revolvers." These revolvers, the indignant veteran wrote, were "such a part of his image and he so forcefully objected to their being called 'pearl-handled'," which Patton considered feminine. $^{71}$

Patton purchased the Colt Peacemaker from the Colt factory directly, which shipped the one Patton ordered on March 15, 1916 while he was stationed in El Paso, Texas. $^{72}$ The revolver was a standard model but Patton immediately customized it to his taste. He added custom ivory grips, the right one being embossed with a raised eagle with spread wings and on the left an interlocked "G S P," his initials. Patton also added customized engraving over nearly all the metal parts of the revolver, but it is unknown by whom, and added a lanyard ring on the bottom of the grips. According to legend, when an American reporter asked Patton about his pearl-handled pistols he apocryphally replied, "Son, only a pimp in a Louisiana whorehouse carries pearl-handled pistols.

\footnotetext{
${ }^{68}$ Ibid., 1-2, 20, 55-56.

${ }^{69}$ Letter, Master Sergeant John L. Sims to Mr. Milton F. Perry, in Historical Property Jacket CCN 455980, General George S. Patton Museum (Patton Archives, October 26, 1954). See also Artifact File CCN 455980.

${ }^{70}$ Jack Pearl, Blood-and-Guts Patton: The Swashbuckling Life Story of America's Most Daring and Controversial General (Derby, Connecticut: Monarch Books, 1961), 31, 122.

${ }^{71}$ Letter, Boardman F. Lockwood to Martin Blumenson Letter, General George Patton Museum (Patton Archives, December 31, 1985). See also Artifact File CCN 455980.

${ }^{72}$ Ronald A. Ogan, "Patton's Peacemaker," American Rifleman 1986, 36.
} 
These are ivory." Patton lamented to his nephew the same sentiments. ${ }^{73}$ The mistake was common. Time magazine reported on August 28, 1944 that with "[s]hrill voice, riding breeches, starred helmet, pearl-handled pistols and all," the US Senate confirmed Patton's permanent promotion to Major General. ${ }^{74}$

Patton purchased his Smith and Wesson .357 Magnum (serial number 47022) for $\$ 60$ while assigned to the General Staff at Fort Shafter in Hawaii. He wanted to add a "killing gun" to his arsenal and this revolver was advertised as such. Shipped to him on October 18,1935 , he quickly personalized it by adding ivory grips that closely matched those on his Peace Maker. ${ }^{75}$ It was easy for most viewers to mistake the two as being a matching pair, a misconception that might be forgiven since the two revolvers had matching customized grips and because Patton carried them in matching custom-made holsters. For example, one report falsely claimed he rode ashore during the amphibious assault in Morocco in a tank then strode into his adversary's headquarters to make surrender demands "with two .45 -cal revolvers strapped to his hips and a tommy gun under his arm. ${ }^{{ }^{76}}$ Less famous than its counterpart, Patton rarely carried the Smith and Wesson piece, and probably only once in combat: during the amphibious landing during Operation Torch in November 1942. According to his driver, Patton only carried it when he might have some heavy shooting to do and that it was not feasible to fire often as its powerful recoil would "tear up your hand.","77 Myth and legend surrounded the pistols

\footnotetext{
${ }^{73}$ Ayer, 73.

74 "Patton Regilded," TIME, August 28, 1944.

${ }^{75}$ Perry and Parke, 40. The .357 Magnum does not have a raised eagle but does have Patton's initials on the right grip.

${ }^{76}$ John Field, "Patton of the Armored Force: "Old Blood and Guts" Leads U.S. Troops in Morocco and Pines to Challenge Rommel to Personal Combat," LIFE, November 30, 1942.

${ }^{77}$ See Letter, Master Sergeant John L. Sims to Milton Perry in Artifact File CCN 455980 (General George Patton Museum).
} 
themselves in addition to Patton the man. Nearly a decade after Patton's untimely death, the museum at the U.S. Military Academy conducted a study amongst veterans who served under Patton during the Second World War as to which he carried into combat. Several individuals who worked closely with Patton, such as Major General Ernes N. Harmon, a Corps Commander who served in the Third Army and a personal friend of Patton's, indicated that although there was only one image to support his assertion, Patton wore both revolvers often. ${ }^{78}$ Was it both the .357 and the $.45 ?$ Were there in fact two Colts? Or perhaps these men saw different weapons unknown to us today.

Unfortunately, by the time of the survey, myth already altered the memory of these individuals, some of whom even referred to the grips as being pearl. ${ }^{79}$ However, what is telling is the sheer volume of correspondence received in relation to the study, the announcement for which both the American Rifleman and the Army Times published. The number of veterans and those interested in Patton and his brand, i.e. the pistols, attest to his popularity of the time. Some of those who took the opportunity to reply also related their affection for their former commander. For many Patton fans, he was "a wonderful man, a great loss to [the] country and [our] fellow man." 80

Years after Patton's death, many soldiers who served under Patton in World War II recalled with clarity the pistol that they identified with the man. Carl Meskill, a veteran of the $34^{\text {th }}$ Signal Construction Battalion, wrote that he recalled the "unmistakable" butt of his single-action Colt when he saw Patton. ${ }^{81}$ James C. Watterson

\footnotetext{
${ }^{78}$ Letter, Major General Ernest N. Harmon (Retired) to Milton F. Perry, in Patton Archives (General George Patton Museum, April 14, 1954).

${ }^{79}$ See series of communications regarding study in Artifact File CCN 455980 at The General George Patton Museum. As an example, refer to Letter from Robert J. Bell to Milton F. Perry, 3 June 1954.

${ }^{80}$ Letter, Louis H. French to Milton F. Perry Letter, in Patton Archives (General George Patton Museum, August 14, 1954).

${ }^{81}$ Letter, Carl L. Meskins to Milton F. Perry, ibid. (June 18, 1954).
} 
recalled three specific instances when he noticed Patton wearing the Peacemaker. ${ }^{82}$

Although there is only one known picture of Patton to prove it, many veterans claimed to have seen Patton wearing the .357 . Some veterans of the war understood the meaning behind the pistols, such as one man who recalled that Patton explained to him, "[Sergeant] if I were seen without these guns, no one would know me, I might as well go on without my ------- pants." 83

After his death, the public's fascination with Patton's pistols and holster rig, even down to the smallest of details, never ceased. R.H. Wilson wrote to the West Point Museum, which displayed the pistols for some time, that he was impressed with the belt buckle worn by George C. Scott in the film Patton and sought information on that particular piece. ${ }^{84}$ After the release of the movie, interest in these aspects of the Patton brand increased. For instance, Sam Boggs, the president of a small rifle club in Ohio, sought information on the types of pistols Patton carried and wanted to know specifics about the holsters, compass case, and first aid pouch that Patton wore on his belt. Patton enthusiasts bombarded museum workers at the West Point Museum and the Patton Museum at Fort Knox, Kentucky with other questions regarding details of the weapons. Guns and Ammo and Shooting Times both inquired into the specifics of the revolvers as well and requested images to include in articles those publications printed in the early 1970s. Guns and Ammo published an article that reiterated the idea that Patton's pistols were more than "mere window dressing," but were "symbols of a sometime maverick's unwavering dedication to leadership." These pistols were arguably the most powerful in

\footnotetext{
${ }^{82}$ Letter, James C. Watterson to Milton F. Perry, ibid. (June 19, 1954).

${ }^{83}$ Letter, Ernie Mrazz to Milton F. Perry, ibid. (September 23, 1954).

${ }^{84}$ Letter, R.H. Wilson to West Point Museum, ibid. (November 23, 1972).
} 
the world, not for their caliber but for how they inspired the "respect and confidence in troops and allies, while they carried forward the image of Patton as a warrior and leader to friend and foe alike." ${ }^{95}$ In 1986 Patton was on the cover of Guns magazine in which an article posited that his "ever-present ivory handled side arms helped make Patton one of World War II's most colorful figures." 86 But public enthusiasm for the weapons did not begin there. In 1959 Guns and Hunting published an article on the Peacemaker, a trend that continues in a plethora of magazines marketed to gun enthusiasts even today. ${ }^{87}$ As early as 1968, Twentieth-Century Fox began requesting specific information about the guns and accouterments in order to make reliable copies for the Patton film. ${ }^{88}$

Popularity naturally turned into profiteering. Much to the dismay of the Patton family and the Patton Museum, The Danbury Mint, a high-end collectibles business, reproduced a non-firing version of Patton's custom Colt along with a wall-mounting plaque. Commercial ventures that capitalized on Patton's fame picked up steam in the 1980s. At the time of the release of Danbury Mint's solicitation there were already several other commemorative versions in the works, including those commissioned by the United States Historical Society and the American Historical Foundation. The Patton family successfully thwarted many attempts to capitalize on the Patton name. ${ }^{89}$

\footnotetext{
${ }^{85}$ Whit Collins, "Patton: Guns Made Him Great," Guns \& Ammo 1971, 30.

${ }^{86}$ Charles M. Province, "Guns of General Patton," Guns December 1986.

${ }^{87}$ See a series of fan mail and letters of inquiry found in Artifact File CCN 455980 at the General George Patton Museum. These magazines are not limited to U.S. publications: in 2014 the Japanese magazine Gun Professionals published an article on Patton's gun collection.

${ }^{88}$ Letter, Paul Wurtzel to West Point Museum Curator Letter, in Patton Archives (General George Patton Museum, May 3, 1968).

${ }^{89}$ See internal correspondence in Artifact File CCN 455980 at the General George Patton Museum.
} 
Patton's contemporaries, especially those who worked closely with him throughout the war, explained the Patton brand and the power it held. Colonel Robert S. Allen, one of Patton's principle staff officers, described Patton as many did:

He was attired in a superbly tailored, form-fitting, brass-buttoned battle jacket, studded with four rows of campaign ribbons and decorations, pink whipcord riding breeches, and gleaming, hightopped cavalry boots with spurs. Around his waist was a hand-tooled, wide leather belt with a large embossed, shiny brass buckle. In his hand was a long riding crop; on his shoulders, shirt collar, and helmet, fifteen large stars. ${ }^{90}$

Allen also wrote of his first visual impression of Patton after meeting him on March 24, 1944, describing him as "Very smartly attired - every stitch of him obviously tailored from overseas cap to boots and combat jacket."91 Even General Omar Bradley wrote that Patton was an actor of sorts who used language to attract attention - everything Patton did seemed to be calculated and considered. ${ }^{92}$ While participating in a bond drive tour in the United States along with General Jimmy Doolittle in 1945, citizens heralded the two men as heroes in Los Angeles, Patton's hometown. Noting the Patton brand, The Los Angeles Examiner wrote a description of him in the paper: "His lacquered helmet bearing the four stars of a full general, the wise old eyes with just the hint of a tear in them, the battle jacket with its five rows of campaign ribbons and decorations, the whipcord cavalry breeches, the belt with a four starred revolver grip protruding from a holster, the riding crop and the burnished cavalry boots" indicated to the masses that their hero had arrived. $^{93}$

${ }^{90}$ Robert S. Allen, Lucky Forward, the History of Patton's Third U.S. Army (New York: Vanguard Press, 1947), 22.

${ }^{91}$ Robert S. Allen and John Nelson Rickard, Forward With Patton: The World War II Diary of Colonel Robert S. Allen (Lexington, Kentucky: University Press of Kentucky, 2017).

${ }^{92}$ Ayer, viii.

93 "Huge Coliseum Crowd Cheers Heroes' Appeal," Los Angeles Examiner, June 10, 1945, A. 
Within ten years after Patton's death, nine populist biographies went into print and all of them extolled Patton in their prose, including vivid descriptions, most of them false or inaccurate, of the Patton brand. The Patton legend, as promulgated in these books, had (and continues to have) many inconsistencies that made objective study of Patton himself extremely difficult even as early as the 1950s. As the curator of the West Point Museum lamented, there were "so many fanciful tales concerning Patton and his pistols" and that "no really competent historian has undertaken to write about Patton to any great extent." Primarily collections of newspaper yarns, the authors of these early biographies did not check sources and chose rather to perpetuate legends and myth, including those regarding Patton's most noticeable brand. ${ }^{94}$ The brand endured for years and continues to do so. Cheap dime-novel type books written for young boys redialed the same old semi-false narratives, describing Patton as a martinet who debuted in the battles in France wearing all spit and polish, with the Colt revolver on his right hip, a French sword on his left hip, and carrying a riding crop. Through both World Wars, Patton maintained a presence at the front, a key aspect of his leadership style. But those who served with and under Patton were not fooled by these accounts, discredited in their eyes, for to them Patton was easily recognized on the battlefield with his "tall, erect figure, distinguished by the jodhpurs, riding boots, and the three silver stars shining on his helmet" as he kept popping up at different sectors along the Third Army front. ${ }^{95}$

Over time, the image Patton created and projected became reality in the minds of most admirers. "'A coward dressed as a brave man... will change from cowardice,"

\footnotetext{
${ }^{94}$ Letter, Milton F. Perry to Major General James L. Collins (Retired), in Patton Archives (General George Patton Museum, March 23, 1955).

${ }^{95}$ Pearl, 116, 22.
} 
assuming the "courageous qualities of the hero." One of Patton's oft-quoted pieces of advice was to never take counsel of your fears. If Patton had one fear, it was that he would display cowardice on the battlefield and dishonor his ancestors. Once, as a cadet at West Point, he stood up from behind a berm where he was lifting targets for his peers to fire at on a rifle range just to hear the bullets whiz around his head and prove to himself that he was not a coward. The oversized general's stars, shiny helmet, and ivoryhandled pistols, along with his profanity and vulgarity helped Patton face that fear by tricking himself into believing that he had not an ounce of cowardice in his bones. ${ }^{96}$

Public opinion about General George S. Patton, Jr. oscillated dramatically from 1941 to 1946 due to both his military exploits and numerous diplomatic blunders. Time and time again Patton's superiors and the public forgave the boisterous commander, allowing the image of a swashbuckling, pistol-toting, hard-nosed fighter to emerge and solidify into a collective memory after Patton's tragic death on December 21, 1945. This memory of Patton, recognizable as George C. Scott playing Patton in the blockbuster film Patton (1970), represented an image embedded in the public's imagination during World War II. Although arguably the most famous general in American History, General Patton's legend nearly collapsed on several occasions. ${ }^{97}$ Media sources projected an image of Patton that shifted - perhaps to reflect public opinion - and helped create what ultimately became a collective memory. Historians, who often get the last say in historical studies, often overlook the role the media plays, which often get the first say.

\footnotetext{
${ }^{96}$ George S. Patton and Martin Blumenson, The Patton Papers (Boston, MA: Houghton Mifflin, 1972), $7-$ 8.

${ }^{97}$ Charles M. Province, Patton's One-Minute Messages: Tactical Leadership Skills for Business Management (Novato, California: Presidio, 1995); "Greatest American Military General of All Time? Public Says Patton, Eisenhower, and MacArthur," http:news.gallup.com. In this poll, Patton placed atop the list in overall votes, particularly with Americans ages 30-49, perhaps due to the continued popularity of the movie Patton released in 1970.
} 
Theirs [the media], however, was the second instance of projection in the creation of the Patton legend after Patton himself.

Many mediums, such as literature, memorials, museums, monuments, or films pass into oblivion without shaping the historical imagination of individuals, institutions, or social groups. As historian of memory Wulf Kansteiner stated, "It is more modest and accurate, although less satisfying, to assume that representations speak primarily to the collective memories of their producers, not their audiences." ${ }^{\text {998 }}$ Kansteiner addressed the difficulties inherent in arguing that people and groups receive, understand, and internalize media projections as intended. However, message reception is apparent in repetition - if a particular memory perpetuates, crossing space and time, it is a collective memory. Mental images and conceptions of Patton established during his life followed a trajectory through the twentieth century and persist today in many corners of American and European culture.

Establishing the pattern of popular media projections from 1941 to 1946 is also essential to understanding the beginnings of the Patton legend. During World War II, journalists captured the public imagination with tales of a pistol-toting, foul-mouthed, hard-charging cowboy general who won brilliant victories, beginning with the pre-war training maneuvers in 1941 in Tennessee, Louisiana, and the Carolinas. For these journalists, language was a powerful instrument in crafting attitudes, particularly when using colorful vernacular to draft mental imagery. With Patton, who loved to shock people with his course language, newspapermen found what they sought. Much of what Patton did and said seemed outrageous by ordinary standards, but often was a studied

${ }^{98}$ Kansteiner. 192 
attempt to work on youthful imaginations. ${ }^{99}$ Publications regarding Patton that flourished during this period were alternately whimsical and provocative, and simultaneously reflected, massaged, and solidified consumers' collective memory of the Patton legend. But those who were close to him understood that image which Patton presented to the public and the media was a façade, albeit a necessary one. Americans needed encouragement at a time when the Germans ran roughshod all over Europe while the U.S. Army ranked behind Portugal's in terms of size at the beginning of the Second World War. ${ }^{100}$

Patton discovered and forged a symbiotic relationship with the press long before any of his contemporaries understood the vital connection between the media and public support for the military. He appreciated the usefulness of press attention for his soldiers' ability to build and foster high morale. Meanwhile, reporters discovered that Patton made good headlines and helped sell newspapers. To his dismay, Patton quickly found himself trapped into the "Blood and Guts" stereotype, a moniker that he was loathe to perpetuate, by an increasingly hostile press. And yet, the press certainly did as much to distort the Patton image and brand as he did and helped solidify it in collective memory. ${ }^{101}$

To quell public anxiety about the state of the U.S. military early in the war, LIFE magazine encouraged readers that their Army was active and in good hands before the U.S. entered World War II. During a series of large-scale military maneuvers in the

\footnotetext{
${ }^{99}$ Alexander G. Lovelace, "The Image of a General: The Wartime Relationship Between General George S. Patton Jr and the American Media," Journalism History 40, no. 2 (2014): 108.

${ }^{100}$ David Woolner, "The "Special Relationship" between Great Britain and The United States Began with FDR," (July 22, 2010), https://rooseveltinstitute.org/special-relationship-between-great-britain-and-unitedstates-began-fdr/.

${ }^{101}$ Lovelace, 108.
} 
American Southeast, the Army prepared for war while news outlets let the nation know what was amiss. Called "overenthusiastic" for his comment that his $2^{\text {nd }}$ Armored Division was "'the strongest forced ever devised by man," Patton was at the helm of a unit that provided the most encouraging military news during 1941 while the German Wehrmacht invaded and occupied several countries in Europe with amazing alacrity with its overwhelming blitzkrieg tactics. Compared to the effectiveness of a German panzer division, the accolades given to the $2^{\text {nd }}$ Armored Division bolstered its commander's reputation. ${ }^{102}$ In fact, Patton appeared in more published photographs taken during the maneuvers than any other general officer. Unknown to information consumers at the time, the articles created a connection between them and the war's most colorful general by giving readers a sense of how an armored unit fought and what Patton's roles were in the sham battles. "Patton rode into American pop culture during the summer of 1941, riding in a tank painted with red, white, blue, and yellow stripes, and dressed in a selfdesigned green jumpsuit topped with a golden football helmet." ${ }^{103}$ A caricature of the United States military was urgently needed and Patton had color to spare. It was during the summer of 1941 that Patton and the press collectively forged the image that later defined him as an American icon and a national figure.

After the Carolina maneuvers in October and November 1941, LIFE magazine informed readers about military matters and personalities, probing for a war hero. Taking front stage was "tough, profane, gimlet-eyed Major General George S. ('Georgie') Patton Jr." Known to his men by many nicknames, this "hell-for-leather" cavalry officer was also one of the wealthiest men in the Army and on many occasions purchased supplies

\footnotetext{
102 "Patton Regilded." 73

${ }^{103}$ Lovelace, 109.
} 
for his troops with his own funds. The short article went on to describe Patton as "a dashing figure," famous for his jingles and atrocious spelling. Playing on an improbable anecdote and embellishing liberally, the article claimed Patton, "[n]ever a shy man," forced his way onto the 1916 Punitive Expedition "by simply barging in [General Pershing's office] and roaring, 'General, here's your new aide.” Patton's colorful language and way of motivating soldiers also came to life for readers. During the maneuvers, Patton questioned a private about his target. Unsatisfied with the answer, Patton exclaimed, "That's not a machine gun. It's a dirty Nazi bastard."104

After training the $2^{\text {nd }}$ Armored Division and establishing the Desert Training Center in California, Patton led the Western Task Force as part of Operation Torch, the invasion of North Africa in November 1942. As Patton's troops consolidated their gains after capturing Casablanca, media sources leaked small details of the battle to the public, which added validity to earlier claims. For those who believed, the general wore a football helmet and a "grim face [that] he sticks out of a turret as he bounces hell-forleather across country in his tank." Patton did not ride a tank into battle or wear a football helmet in combat, but writers embellished, imagining Patton in a tank as he was during the 1941 maneuvers. ${ }^{105}$ Similarly, Newsweek falsely stated that Patton excelled at football at West Point and escaped from a hospital and returned to his unit after being wounded in World War I. The writer claimed that the "Army's top tank expert" was "[f]earless and blasphemous," adored by his men who call him “"Old Blood-andGuts. $" 106$

\footnotetext{
104 "Salute for Victors," Newsweek, June 18, 1945. 49

105 "Coliseum Jammed for Spectacular Tribute to Heroes," Los Angeles Examiner, June 10, 1945. 26

${ }^{106}$ Vincent Sheen, "The Patton Legend - And Patton As Is," The Saturday Evening Post, June 23, 1945. Although Patton did not make the varsity football team at West Point, that did not stop him from using
} 
In 1942, the war in the Pacific did not offer Americans encouraging news. The first battle won by U.S. forces was the Battle of Midway in June 1942 - a few months before Operation Torch. A strategy of trading space for time - surrendering ground while using delaying tactics to buy time while the U.S. Navy rebuilt its fleet after Japan's debilitating attack on naval and air stations at Pearl Harbor - did not breed enthusiasm or optimism stateside and Americans yearned for some good news. In North Africa, Patton's Western Task Force met its objectives later than other forces, yet writers sensationalized Patton's landing. Patton, who was "hard as carborundum and sometimes twice as rough," was a smart leader and Americans enjoyed reading about the exploits of their war heroes, even though the embellishments bordered on pure fantasy. ${ }^{107}$ LIFE magazine kept Americans up to date with the main figures in the war and painted a glowing picture for those unfamiliar with the war's rising stars. Nearly a year after the attack on Pearl Harbor, Americans still needed a morale boost and journalists certainly found something to write about with Patton and his units. Like most publications at the time, a LIFE article by John Field titled "Patton of the Armored Force: 'Old Blood and Guts' Leads U.S. Troops to Morocco and Pines to Challenge Rommel to Personal Tank Combat" (the title alone was enough to peak interest in the general public) gave readers the hero they longed for. Here was Patton, riding in a tank while personally leading troops "through snipers and artillery fire" and accepting the surrender of the Casablanca defenders wearing "two .45 -cal. revolvers strapped to his hips and a tommy gun under his

football analogies in many of his speeches to his men. However, Patton excelled at fencing and the hurdles. Patton also did not escape from the hospital after being wounded on September 26, 1918, opting to recuperate at the hospital before returning to his unit weeks later.

${ }^{107}$ Vincent Sheean, ibid., 61. Patton's pistols were not automatics, nor did they have pearl handles. Patton makes reference to his 1873 Colt Peacemaker during the invasion and is probably what he wore during the surrender. There is no archival evidence to suggest that Patton carried a tommy gun. 
arm." Journalists gave Americans the fighter they wanted and needed, a man not afraid to challenge German General Irwin Rommel, the "Desert Fox," to personal combat. Patton appeared to be an officer who exuded a "vast store of determination" and profanity that won the appreciation of his soldiers. ${ }^{108}$ That is exactly what readers got, in print at least.

The physical description projected to readers is also revealing. Patton, who was "marvelously well-equipped physically" for tank warfare, had piercing eyes, broad shoulders, a narrow waist, strong arms and legs, and stood six feet tall: in actuality these were not ideal features for the small confines of a tank. However, an early mental image of Patton began to solidify, supported with accompanying pictures. As one of the Army's "most fabulous characters," officers and men worshipped or hated him but "all of them have admitted that he is a brilliant strategist and a forthright advocate of airpower and armored forces." Even during the maneuvers, as noted earlier, Patton was a media darling, "the pet of all the newspapermen," who's cocky 2d Armored Division did everything with spectacular flare. ${ }^{109}$

Perhaps foreshadowing the troubles Patton faced after Operation Torch, Field explained that Patton's exploits, while "undoubtedly exemplary to the troops, have tended to obscure Patton's abilities as a military man.” Many politicians and highranking military officers frowned upon personal publicity from an Army general. Patton's abilities as a warrior were clear to writers, who viewed Patton as a "combination of Confederate Generals Nathan Bedford Forrest and Jeb Stuart and of General Custer.” Through articles that spoke of Patton's dash and desire to secure the initiative, a tiger's

${ }^{108}$ Field, 113.

${ }^{109}$ Ibid., 113-14. 
instinct to attack, and an indulgent personal vanity, Patton became beloved by not only his troops but the American people as well. ${ }^{110}$ As the stories went into print, a hero legend emerged, albeit at the expense of accuracy. For example, during the raid on San Miguelito Ranch during the 1916 Punitive Expedition, Field wrote that Patton "found himself backed against a wall trying to reload" while a bandit "peppered away at him." In World War I, "Patton and two companions captured 20 Germans" during the battle of St. Mihiel. ${ }^{111}$ Neither of these tales was accurate, but absolute truth did not matter to the writer, and readers probably cared even less. ${ }^{112}$

What did matter was that any chance of future critique be cut short. Most Americans familiar with the Patton story knew of his social status, yet even his "considerable wealth, which might have harmed a less forthright officer, has not held him back." Instead, Patton lived "comfortably but not spectacularly" and used his money to entertain "in good taste" and even used personal funds to supply his soldiers when Army supply systems failed or stalled. ${ }^{113}$ Furthermore, beneath the profanity and boisterousness were grace and a hard-work ethic that was perhaps the cause of all his success and likeability. Writers fed consumers the idea there was not much the venerable Patton could not do.

In perhaps one of the most colorful descriptions of Patton prior to World War II, the Saturday Evening Post ran a story about him in a series called "These Are The Generals." Patton, it read, was "[t]all, tough, and agile as a snake" who was a "living

\footnotetext{
${ }^{110}$ Ibid., 114 and 16. Historian Carlos D'Este later reinforced the comparison to General Stuart, citing Patton's mastery of the art of surprise and his emphasis on personal reconnaissance. See Carlo D'Este, Patton: A Genius for War (New York: Harper Collins Publishers, 1995).

${ }^{111}$ Field, 117.

${ }^{112}$ For accurate descriptions of Patton in the San Miguelito Ranch raid and the Battle of St. Mihiel, see D'Este; Patton and Blumenson, 83-87, 108-12.

${ }^{113}$ Field, 118.
} 
advertisement for a life well spent out of doors...the perfect physical complement for [his] astonishing initiative and incredible courage...." The author went on to draft a comical account of Patton in World War I. The "indelible picture in the minds of all who say or heard Patton - it's quite impossible to go anywhere in our Army and not meet someone who vividly recalls him - is of a sandy-haired screwball mounted outside the lumbering tank, waving his saber...his spurs digging into the tank's sides, urging his tank drivers onward to the foe." Patton leapt from the tank, ran alongside, "waving his saber, cutting at the luckless krauts..." Patton was a man the Army could trust, and according the Saturday Evening Post, so could all of America. After all, the U.S. had a hero who singlehandedly took out a German pillbox in World War I, "pitching a few high hard ones and a few curves with hand grenades." ${ }^{114}$ Descriptions such as these were absurd. Patton did not ride on his tanks during the Battles of the Meuse-Argonne and St. Mihiel, nor did he carry a saber or throw curveballs with grenades. Yet, writers continued to churn out these projections for captivated audiences.

Not all that journalists wrote and said was a farce, however. After being summoned to take over the II Corps, which Rommel's troops battered at Kasserine Pass in February 1943, Patton helped turn disheartened U.S. soldiers back into a formidable fighting force in a matter of nine days. Time magazine reported, "The Lions Tremble," a sure sign of hope and relief for Americans. Patton's accomplishments in Operation Torch earned the Special Order of Quissam Alaouite from the Sultan of Morocco with a citation that read, "The lions in their dens tremble at his approach." Although many of Patton's antics “caused stiff eyebrows to twitch," there was no denying that Patton's

${ }^{114}$ Ted Shane, "These Are The Generals - Patton," Saturday Evening Post, February 6, 1943, 19 and 81. 
actions during the Battle of El Guettar were successful if not exceptional. Patton "believed too loudly in his own military preachments" and "was passed over several times for promotion," but the military establishment came to terms with the boisterous officer because he got positive results. In North Africa, "Patton now has the Germans at gun point" - good news indeed for Americans who recently read tales of disaster from the African dessert. ${ }^{115}$

In order to get the II Corps back into fighting shape, Patton rampaged through the unit, enforcing strict discipline like an "indignant lion." However, Americans began to understand a more complex Patton than previous articles explained. Patton was also a "lover of sartorial elegance," and was a sensitive soul who cried over his wounded soldiers. His acting was a way to "make men want to follow him and to die for him if necessary." According to one article, all of the previous stories told about Patton created the Patton legend - not the man himself who "is known intimately only by the few." Yet, Patton was still the most adept commander to fight the kind of war raging in North Africa, and readers had "every reason to believe that the right man is in the right place." $" 16$

Whereas early accounts of Patton in the war regaled readers with his exploits, first hailing him as a hero, then later revealing much of his temperament while pardoning his bizarre behavior, the Sicilian campaign created a whirlwind of commentary and inquiry into Patton's actions, much of it mired in controversy. Picking up where most narratives left off after the Battle of El Guettar, writers reinforced the typical Patton stereotype. Patton inspired his troops throughout the campaign in North Africa and Operation Husky,

115 "Patton \& the Devil," TIME, October 1, 1945, 14-15.

116 "Remove Patton from Germany," The New Republic: 8 and 36. 
the invasion of Sicily in July 1943. Patton was calm and contemptuous as he walked the beaches of Sicily while enemy snipers and machine gunners fired at him, kicking sand up at Patton's feet. Readers envisioned a man who praised and cursed his men, leading them with "driving energy," a "ceaseless demand for perfection," and a personal magnetism that was irresistible. But the hero, as the story went, also had a soft side behind his "austere, handsome, hard-boiled face that can be terrible in anger." His was a "high voice that can be soft and caressing, or loud and terrifying." With it, Patton cajoled his soldiers towards victory and Americans supported their most dashing field commander who brought them so much pride. Readers saw that although he was a "salty, colorful character," Patton was actually well read and brilliant. After all, this was the man who victoriously set a tank trap for "The Desert Fox" after reading Rommel's book Infantry Attacks and captured Palermo in a bold battlefield maneuver. Americans began to expect nothing short of victory from Patton after reading these types of projections. ${ }^{117}$

Then Patton's reputation crashed. After the fighting in Sicily shifted towards Messina, Patton toured two field hospitals, as was his custom. While ill, tired, and stressed, Patton found a seemingly well soldier sitting on a cot with no visibly apparent injuries. When Patton asked where his wound was, the soldier reported that the mental strain at the front lines was too much for him to bear. Patton was not a believer in battle fatigue or shell shock, known today as post-traumatic stress disorder (PTSD), and judged the man as a coward. Enraged, Patton slapped the man in the face and ordered the hospital staff to send the man back to the front. Patton was not finished. Upon

${ }^{117}$ Frederick C. Painton, "Old Man of Battle," Reader's Digest: 8-11. 
inspecting another field hospital days later, the same exchange happened a second time with a different soldier.

General Eisenhower pleaded with correspondents covering the Sicilian campaign not to leak the incident for fear of losing the most indispensable commander in the war effort. Patton was the U.S. Army's foremost tank expert and the only general to lead two successful amphibious assaults and the only American to do so with a field army experience necessary for the coming invasion of mainland Europe. As historian Ladislas Farago explained, the newspapermen and radio reporters who were privy to information regarding the incidences entered into a gentleman's agreement with Eisenhower to refrain from breaking the story. ${ }^{118}$ Despite Eisenhower's best efforts to protect Patton, however, the scandal burst into the open. The first to reveal the story was Drew Pearson who reported the incident on a Sunday radio program on the American Broadcast Company network. The story was an immediate sensation. In addition to a public outcry, several U.S. Congressmen got involved, demanding a full investigation. ${ }^{119}$

At first, the reports were not kind to Patton. Subtitles such as "War's Underside" and "Conduct Unbecoming" littered newspapers, magazines, and journals. The reports of "the first scandal in the U.S. Army High Command" shocked Americans as writers described Patton as "gaudy and profane" and who committed one of the unforgivable military sins by striking, vilifying, and degrading two enlisted soldiers. ${ }^{120}$ U.S. citizens and Congress initially regarded the incident as a single isolated affair but some reporters began rehashing old stories, piecing them together to create a master narrative of an

\footnotetext{
${ }^{118}$ Ladislas Farago, Patton: Ordeal and Triumph (London: Barker, 1966), 346.

${ }^{119}$ Ibid., 350.

120 "The Mouth," Newsweek, October 15, 1945, 63.
} 
acrimonious, rash, and bellicose officer who was known for his demands for perfect discipline but who could not control himself. For example, one call for action stated, "General Patton [is] familiar with the Articles of War," was guilty of conduct undermining discipline, and "should be relieved instantly" of his command of the Seventh Army. ${ }^{121}$

It is true that Congressmen received many letters from outraged citizens who demanded an investigation into Patton's conduct or that he be thrown out of the Army. An officer "that can't control himself any better than that is not fit to command a company, much less an Army." ${ }^{\text {"22 }}$ However, public outcry against Patton eventually faded out of the headlines. And yet, the incident remained in the collective memory of most Americans and came back to haunt Patton later when he served as the military governor of Bavaria in post-war Europe.

Initial newspaper reports attempted to exonerate General Eisenhower for his part in the cover-up. However, later projections introduced the idea that "the General's [Patton's] crime was no greater than the Army's in hushing it up for so long." ${ }^{123}$ Almost as quickly as calls for Patton's relief appeared, excuses for Patton's behavior appeared in print as well. To some writers, Patton, "the General who does not believe in nerve difficulties" but "had some himself," was the victim of a single crusading journalist. Members of Congress sought the truth behind the incidences, but Secretary of War Henry Stimson believed that decisions regarding theaters of war belonged to commanding generals. In fact, most Americans "did not shout for General Patton's scalp." While

121 "Auld Lang Syne," TIME, October 15, 1945, 69-70, 72.

${ }^{122}$ Quoted in Farago, 350.

123 "The Mouth," 63. 
some newspaper editorials called for drastic measures and there was "much dinner-table clamor," there was hardly a sustained public uproar. In fact, the father of one of Patton's slapping victims wrote to his Congressman a letter forgiving Patton. For many journalists, the real culprits ultimately became the officers involved in the cover up. ${ }^{124}$ Attitudes reflected in printed media regarding the slapping incidents shifted in a matter of weeks from initial outrage, to indignation, and then understanding. While there were still calls for action against Patton from private citizens, blame from the media shifted mostly (but not completely) to those responsible for not disclosing the incidences. The general was "in a highly emotional state" and needed rest. However, the "[A]rmy censorship was revealed as incredibly stupid," as "anybody with any sense must have known that [the story] would leak out." ${ }^{125}$ Furthermore, overall morale was still high and when Patton spoke in public, he did so in front of "thunderous applause." Conversations in Congress began centering not on the question of removing Patton from command, but instead focused on the issue of Patton's permanent rank promotion from Colonel to Major General. ${ }^{126}$ Regardless, media still projected that "people at home, who have been brought to a high pitch of admiration from the soldiers who do the fighting, and of gratitude to them, are not going to see them slapped around by surly and arrogant officers." ${ }^{127}$ Some indignant journalists continued to call for action.

Eisenhower ordered Patton to apologize to the offended soldiers and the officers and soldiers of the hospitals where the slappings occurred. Patton took the order a step further and toured his entire army, apologizing to every possible unit under his command.

\footnotetext{
124 "Patton, The Soldier," The New York Times, October 9, 1945, 15-16.

125 "Patton Rebuked," The Scholastic, October 22, 1945.

126 "General Patton," Newsweek, December 17, 1945, 60-64.

127 "General Patton's Indiscretion," The Christian Century LX, no. 49 (1943): 1427-28.
} 
Of course, the apologies were not entirely sincere - Patton never admitted that his motive was incorrect. Interestingly, after the initial fervor surrounding the slapping incidences died down, as well as the fighting in Sicily, printed reports on Patton lightened. Patton, the "[b]estower of the "slap heard around the world" "went into exile after most units of the Seventh Army left for duty on mainland Italy. ${ }^{128}$ He essentially did lose his command: bit-by-bit. Likewise, Patton slowly faded from the headlines.

Patton's fall from grace created an opportunity for the planners of Operation Overlord, the amphibious assault landings on the Normandy beachheads on June 6, 1944 . The German high command knew more about Patton's whereabouts during his exile than most Americans. Allied General Headquarters played on the German's concern of Patton's location and sent him on a tour of the Middle East while German intelligence tracked his whereabouts. Patton's name rarely appeared in print during this time in American newspapers, and the lack of news after his relief from Seventh Army command caused some anxiety for the public. To ease apprehensions about the boisterous commander's ousting, ideas of Patton's necessity for victory slowly crept back in the papers. For example, "apart from the soldier-slapping the fact remains that as commander of the II Corps in Tunisia...Patton distinguished himself in both attack and defense," and "for some soldiers Patton is a fierce inspiration." Eisenhower did not feel confident in the war effort "without the two-gun General" and did not intend to conduct operations without him. ${ }^{129}$

128 "General Orders No. 121," (Washington, D.C.: War Department, December 22, 1945), 570.

129 "Command: Death \& the General," TIME, December 31, 1945, 27. 
When Patton emerged from obscurity, he immediately found himself in the media spotlight for all the wrong reasons. ${ }^{130}$ During a speech at the opening of a club for soldiers in Knutsford, England, Patton allegedly claimed that it was the destiny of the Americans and English to rule the post-war world. In retrospect, the comment seems innocuous but at the time it was an unforgivable gaffe for the press who decried the fact that Patton left the USSR out of his statement. Secretary of War Stimson promptly "pointed out that Patton spoke for himself" and at least one U.S. Congressmen described Patton's “[s]crewy talk...as balmy as Hitler's...nonsensical...mischievous.” Patton "again put both feet in his mouth, where there was obviously room for his cavalry boots as well." ${ }^{131}$ Although Patton did not understand the gravity of his remarks, there were many protests regarding his implied beliefs that some U.S. allies, in particular the Soviet Union, were insignificant in the world order after the war. For many policy makers and reporters, remarks such as this were simply unacceptable and insulting to one of the Allies whose participation in the war was absolutely necessary for victory. Patton nearly paid a high price for saying them. Once again, Eisenhower reluctantly came to Patton's rescue out of sheer necessity.

During Operation Fortitude, the Allies' deception plan aimed at drawing German forces away from landing sites at Normandy, Patton once again fell into partial obscurity while he waited his turn to land in occupied France. Sensors only allowed news leaks about Patton that fueled the deception plan; hence readers in the U.S. did not have a clear picture of Patton's whereabouts. Certainly, the Germans, who considered Patton the best

\footnotetext{
${ }^{130}$ Martin Blumenson and Kevin Hymel, Patton: Legendary Commander (Washington, D.C.: Potomac Books, 2008), 580.

${ }^{131}$ Martin Blumenson, The Many Faces of George S. Patton, Jr, The Harmon Memorial Lectures in Military History, (Colorado Springs: U.S. Air Force Academy, 1972), 66, 68.
} 
field army commander the Allies had, were very concerned about Patton as well. Hitler maintained the bulk of his defensive forces north of Normandy, poised for a counterattack near the Pas de Calais, the shortest route across the English Channel and the location where falsified plans indicated Patton's mythical First U.S. Army Group would attack. When Patton finally emerged from the shadows during Operation Cobra, well south of where German intelligence sources anticipated his arrival to continental Europe, journalists revealed that it was he who led the breakout from the Normandy hedgerows. Patton "set a new record for the distance between doghouse and popular acclaim." It was also Patton who "rampaged through Brittany and was now closing on Paris" and "immediately became a full-blown hero." It seemed that "the world loves a winner" after all. As attitudinal shifts about Patton indicated, "a fire-and-brimstone fighter like Patton was just what was needed to whip the faltering Germans." ${ }^{132}$ Patton once again held the admiration of the American public and regained favor with the press as his Third U.S. Army blew through German defenses and mauled Nazi forces as it attacked, at one point, in every cardinal direction. Moreover, "the Senate fell over itself to confirm his nomination to permanent rank of major general."133 Winning was the cure for all Patton's woes.

After the German's Ardennes Offensive in December 1944 and January 1945 that threw U.S. forces into a general retreat, Patton's name once again lit up the printed news when his Third Army helped restore Allied positions and then regain the initiative offensively. In an intuitive narration of the Patton legend pendulum swing, Collier's

\footnotetext{
${ }^{132}$ George Forty, The Armies of George S. Patton (London: Arms and Armour, 1996), 27.

${ }^{133}$ Michael C. Bilder and James G. Bilder, A Foot Soldier for Patton: The Story of a "Red Diamond" Infantryman with the U.S. Third Army (Drexel Hill, PA: Casemate, 2008), 61.
} 
noted that Patton's reputation went through "convulsive shifts in public opinion." The "Hall of Fame can change into a rogues' gallery overnight, and vice versa with equal ease and rapidity." Patton was on top again. After all, the commander who "stormed the bastion of Metz for the first time in modern history" and relieved the beleaguered $101^{\text {st }}$ Airborne Division at Bastogne, Belgium was "scarcely more than a year ago...in the doghouse." Collier's raised the questions of what brought about this transformation of public attitude, how Patton escaped consternation, and how he justified his ascendency from the backwaters of the war. After all, if people thought that "the change is due to a change in General Patton, they will do well to ready themselves for a rude awakening."134 Patton was the same person who belittled U.S. allies in the Knutsford incident and slapped two soldiers in Sicily.

The explanation was simple. "Had [Patton] been no more than a bold and impetuous cavalryman, the soldier-slapping incident would have ended his career.” But Patton was far more than that. Love or despise him, ignoring Patton was impossible. Often compared to figures like Babe Ruth, Patton gave many people feelings of exhilaration as they read about him and his army's exploits. Soldiers thought of him as "'a big guy who's going to kick hell out of something." 135 Writers clamored to dig up new stories about Patton, but try as they may they ran into the legend of Patton when interviewing soldiers who served under him, and that was the story they wrote. Typically beginning by regurgitating the same tales told to readers earlier in the war, writers in Europe seeking color commentary began to project to the public the same image of Patton that his men held.

\footnotetext{
${ }^{134}$ George Creel, "Patton at the Pay-Off," Collier's, January 13, 1945, 24.

${ }^{135}$ Ibid., 25.
} 
By the time the Third Army crossed the Rhine River, Patton began to worry about the toll his branding took on popular conceptions about him. Ever the actor, he never quite became the persona he played. And keeping up the ruse began to wear on him as well. ${ }^{136}$ Regardless, he continued his use of the press for psychological purposes and saw its usefulness in ways few of his contemporaries did. He strove to give credit to individual solders and allowed correspondents to reveal which units partook in certain actions. News stories, Patton argued, improved morale by giving individuals and units publicity at home. Pride in the soldiers' units generated a spirit of belonging to an elite organization and confidence in ultimate victory. ${ }^{137}$

The ending of the war in Europe consumed headlines in the summer of 1945, but doubts about who was the biggest war hero for Americans vanished when Patton came back to the states to participate in bond drive ceremonies and parades in Boston and Los Angeles in June. Headlines such as "Salute for Victors" and "Coliseum Jammed for Spectacular Tribute to Heroes" caught readers' attention. ${ }^{138}$ Millions of people watched the parades and listened to the speeches made by Patton as well as General James Doolittle. Like Caesar riding a chariot into Rome as a conquering hero, Patton stood erect in an open-aired military vehicle as it took him through his hometown where he received gratitude and recognition from the crowd as one of the city's favorite sons.

There were many legends about Patton while he was in the Army, particularly during World War II. Reporters capitalized on the stories, attempting to differentiate between myths and who Patton really was as a person. The "half-legendary and half-real

\footnotetext{
${ }^{136}$ Lovelace, 116.

${ }^{137}$ Ibid., 118.

138 Warrior; The Story of General George S. Patton, (New York: Putnam, 1967); Charles R. Codman, Drive (Boston: Little, 1957), 30.
} 
character" was in part a combination of "godliness, Virginia ancestry, California birth, great wealth, good looks and strength, plus a passionate inherited patriotism." Yet, most reporters realized the Patton image was a façade that Patton himself crafted, even if they were unaware that they too played a key role in the perpetuation of the collective memory. In fact, Patton "creates legend as easily as he breaths," legends that were solidly rooted in reality - or rather a somewhat distorted view of reality crafted and projected by journalists. The Patton image - a shiny helmet, polished boots, tailored uniform replete with medals and ribbons, custom-handled revolvers, a horse-riding crop, and a practiced frown - became a brand recognizable to everyday Americans. Stories of Patton's bizarre and audacious behavior throughout his career added to the mystique. Vincent Sheean of the Saturday Evening Post recalled tales of Patton's 26 polo horses he brought with him to a desolate post in Texas, a shootout during the 1916 Punitive Expedition, the famous prayer for good weather during the Lorraine Campaign in late 1944, the bizarre prototype uniform he created that earned him the nickname "The Green Hornet," and of course the race across France after the breakout at Normandy. Sheean argued that although many called Patton "a brute" during a "wave of indignation which swept the United States" after the slapping episodes, there were reasons behind such behavior that needed to be understood. Patton, who believed claiming shell shock and battle fatigue were acts of cowardice, thought, "Courage and fear are phenomena which can be governed by training and discipline," and was "incapable of understanding any other point of view." That did not stop his soldiers from adoring him. Through nearimpossible feats, Patton earned the trust of his soldiers. "Indeed, of all the legends about 
Patton, the most inaccurate is that he is a tank general." Patton was "an Army general first and foremost" and understood all aspects of modern warfare. ${ }^{139}$

According to the news, no other army captured more soldiers or more territory than Patton and his Third Army during the race to Berlin. "The Germans seemed to be scattering before Patton's attacks. They had reason to fear him." The Germans were aware of the Patton legend as well but were more interested in, and had a healthy respect for, his capabilities. Patton, who was "definitely a nomination for Public Hero No. 1 of the war in Europe" was "fast becoming a legend." Unlike the Congressmen who stalled Patton's permanent promotion, the U.S. public “liked Patton's flourishes, his flamboyance, his victories." Finally, "hero-worshipping Americans had a candidate to fit the mass idea of what a Hero General should be - the colorful swashbuckler, the wildriding charger, the hell-for-leather Man of Action, above all the Winner." Not only did the media tell readers that Patton was a legend and the hero of the war, they told the public exactly what the expectations were for such a person. Patton the man "can be engagingly attractive - urbane, almost courtly in manner, quiet in speech" with a "high social polish," while at the same time profane and vulgar. ${ }^{140}$ However, this was all for show, a necessity for developing morale and esprit de corps within the units under his command. Patton, like George Armstrong Custer and Teddy Roosevelt, was "loud, swashbuckling, [and] profane," just "the kind of soldier who makes legend as spontaneously as he inspires the fierce and prideful affection of his men." ${ }^{141}$

\footnotetext{
${ }^{139}$ Sheean, 9-10, 44, 45, 50, 53.

${ }^{140}$ George Forty, Patton's Third Army at War (Shepperton: I. Allan, 1978), 15-16.

${ }^{141}$ Alden Hatch, George Patton, General in Spurs (New York: Messner, 1950), 19.
} 
The pedestal upon which the media placed Patton crumbled once more, at least momentarily, after the fighting in Europe ended. Patton served as military governor of Bavaria, the birthplace of the National Socialist (Nazi) Party, after the war while U.S. troops occupied Germany. Claiming that there were not enough qualified German civilians there who were unaffiliated with the political party to maintain the infrastructure and local governments, Patton disregarded Eisenhower's order to remove former Nazis from local government, stating, "To get things going, we've got to compromise with the devil a little bit." To make matters worse, during a press conference, Patton likened "This Nazi thing" to a "Democratic-Republican election fight.". correspondents, it "should be obvious to everyone that a man of so limited a sense of democratic responsibility is ill suited to govern in Germany and should be removed as soon as possible." ${ }^{143}$ Even though Patton successfully governed in Morocco earlier in the war in a much more ambiguous situation with former Vichy French colonial overlords, Berbers, Jews, and Muslims living in the same area, this negative point of view became common conception.

Eisenhower called Patton to his headquarters in Frankfurt. Upon arrival, correspondents recalled that only his "lacquered helmet lining hinted at Patton's usual satirical glory."144 Patton had little reason to smile. "Old Blood \& Guts was in Dutch again" and "made a fool of himself" while "holding a press conference and pooh-poohing efforts to rid Germany of Nazis." He also ignored the policies and orders of the Supreme Commander, and this time there was a reckoning. After ordering a press conference

\footnotetext{
${ }^{142}$ Alden Hatch, General George Patton: Old Blood \& Guts (New York: Sterling Pub. Co., 2006).

${ }^{143}$ Ian V. Hogg, The Biography of General George S. Patton (London, New York: Hamlyn, 1982), 420.

${ }^{144}$ William Bancroft Mellor, Patton, Fighting Man (New York: Putnam, 1946), 53.
} 
"retake" that only exacerbated his problems, Patton blamed his plight on unfortunate analogies and sensationalized newspaper headlines. As Lieutenant General Walter Bedell Smith stated for the papers, Patton's "mouth does not always carry out the functions of his brain. George acts on the theory that it is better to be damned than say nothing - that some publicity is better than none." After another two hour and 25 minute conversation, Eisenhower formally relieved Patton from command of Third Army. ${ }^{145}$

After Eisenhower fired Patton as military governor of Bavaria, the American press "roiled in pro and con commentary. For every editorial glad to see Patton go, there was another" that claimed a leftist bias which was trying to denigrate Patton as a scapegoat. Then suddenly, as it had before in times when Patton seemed destined for the doghouse, editorials across the nation praised him again. He received flattering newspaper clippings from admirers. Patton was decorated by Charles de Gaulle and spent nearly a week touring France and receiving thanks from the people who greatly admired him. The King of Belgium decorated him as a Grand Officer in the Order of Leopold and he toured Denmark and Sweden, receiving honorary citizenships from many of the towns and cities he and his army liberated. ${ }^{146}$ Mirroring the shortened shifts in public opinion in late 1945, Patton's relief as commander of Third Army exemplified how quick writers were to forgive the war hero. Eisenhower transferred Patton to command the Fifteenth Army, essentially a "transfer to nothing." 147 The Fifteenth Army

\footnotetext{
${ }^{145}$ General Patton: The Last Cavalier (New York: Putnam, 1971), 30, 53. On page 30, readers saw a cartoon titled "Uncle Ike Spank" depicting an angry-faced Eisenhower pulling Patton as a crying child by the hand with a sign pointing the way "To the Woodshed." Eisenhower is depicted saying, "This will hurt me more than it does you!"

${ }^{146}$ James Kelly Morningstar, Patton's Way: A Radical Theory of War (Annapolis, Maryland: Naval Institute Press, 2017), 239-41.

${ }^{147}$ Roger H. Nye, The Patton Mind: The Professional Development of an Extraordinary Leader (Garden City Park, New York: Avery, 1993), 65.
} 
was an army only on paper, a group of headquarters personnel relegated to writing the history of American involvement in the ETO during World War II. Yet, ordering Patton to this "particularly galling desk job" was an act of mercy. Patton's “distinctly poor record as Military Governor of Bavaria" did not completely overshadow his stellar wartime accomplishments. Many thought that Patton "should never have been made an occupation governor."148 This sentiment echoed throughout October 1945. The New York Times even offered an obituary of sorts. "Patton," it claimed, "has now passed from current controversy into history. There he will have an honored niche." Hoping that Patton would "share the sense of relief" at getting "so safe and quiet a transfer," the author reinforced the notion that perhaps it "was a mistake to suppose a free-swinging fighter could acquire overnight the capacities of a wise administrator." In a sense, the public began to read that Patton was a victim of his own successes and peacetime circumstances. "Patton was one of the great field commanders of the war" and the "record of the battles he fought and won will still stand firm." administrator, the paper promised, would soon be forgotten. Indeed, "Good generals are not necessarily good civil administrators." 150

Patton quickly became bored with his new assignment and he spent much of his time away from his desk horse riding, hunting, and traveling to receive awards and recognition from liberated European nations. Readers were shocked to discover that on the way to one of his regular pheasant hunting trips on December 9, 1945, just a few days

\footnotetext{
148 Benjamin Patton and Jennifer Scruby, Growing Up Patton (New York: Berkley Caliber, 2012), 29-30.

${ }^{149}$ George S. Patton, Paul D. Harkins, and Beatrice Banning Ayer Patton, War As I Knew It (Boston: Houghton Mifflin Co., 1947).

${ }^{150}$ George S. Patton and Kevin Hymel, Patton's Photographs: War as He saw It (Washington, D.C.: Potomac Books, 2006), 18.
} 
before his scheduled return home, Patton's Cadillac collided with a U.S. Army truck, throwing Patton against the front seat, fracturing his neck vertebrae, and paralyzing him from the shoulders down. ${ }^{151}$ The news took the American public by surprise, but optimistic initial reports put readers at ease. The Army "announced that its troublesome favorite was 'out of danger"' even though he might be partially paralyzed. ${ }^{152}$

Patton died peacefully on December 21, 1945 after a 12-day struggle for his life in a hospital in Heidelberg, Germany. Headlines such as "Campaign Ends" and "Los Angeles Loses a Son" told Americans the fateful news and reflected the growing positive sentiments surrounding Patton. On December 22, 1945 the War Department issued General Order No. 121, announcing Patton's death and reassuring service members that "General Patton...inscribed his name in the annals of military history."153 Throughout his career, Patton "rode bloody but unbowed through all the military and political crises his vaunted guts and violent tongue seemed to attract." 154

The media could not resist rehashing many of the popular legends surrounding Patton and reporters could not bring themselves to further tarnish the reputation of a dead man, particularly one as famous as Patton. The narrative that emerged was one of forgiveness and understanding. Although the slapping incidents raised the greatest homefront furor of the war, Patton was as "spectacular in his tactics as in his speech" and Americans found it easy to look past his little faults and focus on his achievements.

\footnotetext{
${ }^{151}$ Robert H. Patton, The Pattons: A Personal History of an American Family (New York: Crown Publishers, 1994).

${ }^{152}$ Pearl, 54, 75. Ironically, this article published three days after Patton already passed away.

153 "General Orders No. 121."

${ }^{154}$ Perry and Parke, 48.
} 
Accordingly, Patton's final resting place was "in the midst of the area where he won his greatest fame and where his achievements will be remembered forever." ${ }^{155}$

Succinct epitaphs abounded in articles printed in newspapers and magazines, attempting to make sense of the tragedy and perpetuating the enshrinement that began well before the car accident. "Thus ended the career, but not the legend, of the most spectacular, most controversial U.S. field general in World War II.” Whoever wrote the history of the war, "the roaring campaigns of George Smith Patton...must make an honorable chapter." Most of his men "caught his spirit; some hated him. But nearly all admired his military achievements." 156 The public, media, soldiers, and fellow officers who admonished Patton and his boisterous, brash style found a way to finally forgive and exalt a winner, setting in motion an enduring collective memory of Patton.

The collective memory that emerged, it should be reiterated, was based on the legend that both Patton and news outlets helped create. As Charles Codman, Patton's aide-de-camp, reflected, it was rather strange how imperfectly and incompletely publicity revealed his true character. The impression of Patton that the public received from the press was primarily that of a two-dimensional cartoon, a "swashbuckling, sulfur breathing, pearl-handled 'superman' packaged in tinsel and labeled Old Blood-andGuts." Codman admitted that it was fair to say the general did little to discourage the portraiture, and on occasion even played up to it. Although he understood the benefits of publicity, skill in public relations was never his forte. True, he benefited greatly from the press, even as they misunderstood him. What seemed to escape most contemporary journalists was the fact that General Patton was difficult, if not impossible, to understand

${ }^{155}$ Ibid.

${ }^{156}$ Charles M. Province, The Unknown Patton (New York: Hippocrene Books, 1983), 21. 
as a contemporary figure: he was a combination of his time and his tendency to model himself after his ideal of the romantic warrior of bygone eras.

Projections missed many aspects of Patton's character. Take, for example, how deeply he cared for his troops and how emotionally affected he was by seeing them wounded or killed. That side of the Patton's nature remained unpublicized for decades: the side of his nature which on countless occasions in Africa, Sicily, France, Luxembourg, and Germany impelled him to visit the wounded in field and base hospitals. Not one of his correspondents saw him standing, sitting, or kneeling by a bedside or cot, the hand of a desperately wounded soldier in his - the murmured words of encouragement and the pain and tears in his eyes, the measure of Patton's innate humanity and kindliness. Yet, surely the correspondents following him sensed his compassion, which seemingly eluded commentators and politicians. In truth, all his life Patton was obsessed with an almost neurotic aversion to suffering and cruelty. It was this quality - so difficult to square with the legend - which sheds light upon some of the contradictions and anomalies of Patton's character. ${ }^{157}$

Dashing, fearless, blasphemous, rash, loud, heroic, and legendary - words the media used to describe Patton also indicated the ups and downs of his World War II career. The compounding effect that the preponderance of positive reports had on war news consumers made it difficult for them to view Patton as anything but a larger-thanlife hero. Illustrating these projections in a study such as this one admittedly also makes it difficult to maintain a nuanced, objective view of the man, but that only proves the point. Wartime news outlets followed the Patton story because he made great headlines

${ }^{157}$ Codman, 270-74. 
and helped sell newspapers - it was a journey that took readers on rhetorical swings created by Patton's exploits, gaffes, victories, and failures. But it wasn't the press that created the Patton image - it just propagated it. To be sure, Patton's words got him into trouble with the press, but his actions on the battlefield salvaged his career and reputation. Readers came to know Patton through the media's projections as a magnificent trainer of soldiers and a spirited and colorful combat commander in the early years of World War II. Then, the public became aghast at the slapping incidences on Sicily and Patton's misspeak at Knutsford, England. Americans overwhelmingly forgave the troubled commander because of his wartime performance, but Patton's failure to remove Nazis from local government in Bavaria became the impetus for his relief. Yet, even refusing to follow orders was forgivable for a hero. Finally, reports about Patton's sudden death and the outpouring of sympathy from an adoring public solidified his membership in the pantheon of American heroes. This image endured as the Patton legend and became the basis for a collective memory perpetuated by history workers, historians, filmmakers, and biographers that continues to this day. Patton emerged from World War II with a public persona few others could match. Today, his name still brings to mind the image of a profane, outrageous, and victorious leader of men, epitomized in the nickname "Old Blood and Guts."158 He truly became a household name.

\footnotetext{
${ }^{158}$ Lovelace, 108.
} 


\section{CHAPTER III}

\section{A HOUSEHOLD NAME}

All officers, and particularly General Officers, must be vitally interested in everything that interests the soldier. Usually you will gain a great deal of knowledge by being interested, but even if you do not, the fact that you appear interested has a very high morale influence on the soldier. General George S. Patton, Jr.

Individuals who served in Patton's command at various points during World War II were also major drivers of the Patton legend. These individuals came home with a sense of personal identity intrinsically tied to that of their former Army Commander and developed a sense of pride in being associated with such a notable figure, even before Patton's death in December 1945. Patton's personal brand, coupled with the galvanizing speeches he delivered, his high visibility on the battlefield, and his propensity to achieve positive results, left these veterans with a lasting impression, even amongst those who found him disreputable.

The intent of the Patton brand described in the previous chapter worked on most of the men and women who served under Patton. His aide-de-camp wrote, "an entire army, from corps commander to rifleman, is galvanized into action by the dynamism of one man."159 For those meeting Patton for the first time, his reputation preceded him. For example, a bomber crew shot down over France had the opportunity to meet their hero in person when invited to Patton's Third Army headquarters to brief the general. "The boys loved it. They also, one and all, had got a real bang out of the General. 'What

\footnotetext{
${ }^{159}$ Linenthal, 35.
} 
a guy!' they kept saying. The tail gunner, and youngest member of the crew, had been rather silent. 'Gee,' he said during a pause, 'I never thought I'd get to meet him. It was worth being shot down for." The entire crew shared this sentiment. ${ }^{160}$

Patton wanted his name as well as his image to be well known among the frontline troops and it was his fervent desire for those troops to be known for their aggressiveness and pride that he portrayed himself. When he was at the front, Patton intended for his men to see him there and recognize who he was in order to leave little doubt that the general was not afraid to share the hardships the combat troops faced. Patton "was always gone up to the front," according to Fred Hose of Lucky Forward's (the codename for Third Army's headquarters) military intelligence section. He had a horn [ambulance siren] on his jeep, which "was his way of letting the troops know that the Old Man was going up to the front. It was funny. Humorous. Really was, going hell bent for leather like that." ${ }^{\text {161 }}$ George Davis, a platoon sergeant in the $8^{\text {th }}$ Infantry Division recalled, "'He was right there with the troops. Patton was a good general. Always in the middle of the action."'162

The commander of the $26^{\text {th }}$ Infantry Division said during the Battle of the Bulge that he was so cheered that Patton did not relieve him after a mistake "there was nothing I wouldn't do for the man." General Van Fleet, the commander of the $90^{\text {th }}$ Infantry Division remarked about Patton's leadership and command style, stating, "When you praise somebody, damn it! You have to go out and succeed, and that's in football. That's in anything. You capture the art of leadership there, and that was one of Patton's prime

\footnotetext{
${ }^{160}$ Codman, 184.

${ }^{161}$ Lande, 118, 22.

162 Ibid.
} 
qualities." Patton had a penchant for transferring his energy and enormous selfconfidence, which some critics ascribed to mere hubris. However, the effects of Patton's public personality are difficult to argue against. Patton was indeed boisterous and outspoken, but it was on purpose. General Otto Weyland, commander of the XIX Tactical Air Command that supported Patton's Third Army, noted that he loved "the old guy," considering Patton the best field commander that the world had ever seen. The effects of Patton's personality were not restricted to upper levels of command. Private James Graff recalled when Patton gave "the old hubba bubba," his ability and willingness to "satisfy the basic soldiers' need for recognition explains why he was cheered by the soldiers of the $90^{\text {th }}$ Infantry Division when he drove through their columns." Contrary to critiques, Patton regularly sought and received advice from his subordinates, demonstrating a high level of trust in the troops of the Third Army. He was "open to frank discussion and suggestions from his staff and subordinates before issuing orders," often accepting advice against his better judgment. ${ }^{163}$

According to many of his troops, Patton's martial skills, personal and moral courage, and loyalty were the qualities that essentially made him a hero to many of his men. These attributes were the reason why the troops respected and admired him so profoundly, despite the fact that he always demanded more of them than any other Army Commander. Although he appeared aloof and reserved to some, he nevertheless was generally a warmly human and personal leader to his subordinates, regardless of how he appeared in public or the admonishments he delivered in private. Patton shared dangers and made most people feel as though they were integral parts of the team. "That is why

\footnotetext{
${ }^{163}$ John Nelson Rickard, Advance and Destroy: Patton as Commander in the Bulge (Lexington: University Press of Kentucky, 2011), 304-5.
} 
Third Army men always proudly proclaimed that they are Third Army men."164 Even many women who served as nurses with the Third Army spoke well of Patton. Eileen Biersteker, a nurse with the $65^{\text {th }}$ Field Hospital, remembered, "Of course, we had heard about Patton before we saw him. From what we heard, we knew he was a very strict man. And used profanity quite a bit. But he knew what he was doing. He was a very, very splendid looking man. Stood straight, tall, and imposing.... But I think a lot of us were happy to be in the Third Army under Patton. I know we were. He was a good general." 165

The crass vocabulary, the emphasis on frightfulness to his subordinates, and the simulated rages represented symptoms of the conflict between his inner nature and the demands of his chosen profession, disparities that sometimes, though not often, led him astray. After bawling out a delinquent in his own inimitable manner it was not unusual for the General to remark, "A good cussing-out is the only way. I've got to make them more scared of me than they are of the Germans." After time, however, his subordinates, including staff, drivers, and orderlies, and the common combat soldier became accustomed to him. Patton's dog Willie was not afraid of Patton either, an animal "at whom in public he thunders and in private croons a kind of baby talk," nor was the exhausted division commander whom Patton habitually "brought back to his own quarters, patted on the back, put to bed, and, a day or two later, sent off refreshed, rejuvenated, recharged - confident in the knowledge that whatever is in store, he will be backed to the hilt." Tankers and rifleman up front "to whom the name of Patton means the captain of the winning team, a captain who demands much, but nothing that he

\footnotetext{
164 Allen, 32.

165 Lande, 188.
} 
himself has not done or is not prepared to do" save for "the congenital shirker, the phony, and the misfit," had little reason to be unduly afraid, in the religious sense, of the general. Patton's gift for leadership, in the view of at least one of those who worked closely with him, was based not on fear, although that was what he initially attempted, but rather upon the dynamism of total dedication and communicable humanity. ${ }^{166}$

Patton believed one way of connecting to the common soldier was by means of the vernacular he used when communicating with them. Although educated at the prestigious U.S. Military Academy, having a privileged childhood with a wealthy family, and being naturally cerebral, Patton trusted the value of shock when addressing his troops. Hearing a general officer speak like a private, Patton thought, allowed the frontline soldiers a means to associate themselves with him and he attempted to connect to many through the speeches he gave prior to sending his men into combat. According to one junior officer in the $95^{\text {th }}$ Infantry Division, Patton "talked the language of the troops. Furthermore, he talked common sense. I made a mental note of the fact that much of the guidance he gave us wiped out a lot of the Mickey Mouse stuff that we had been forced to digest on maneuvers in the U.S. Here was a leader of men worth following into battle." Another junior officer reminisced, "That old son of a bitch makes you feel like you can do anything and nothing can stop you." 167 When describing the fever pitch amongst the troops during one of Patton's famous "blood and guts" speeches, Jess Larson, an artillery officer with the $45^{\text {th }}$ Infantry Division, stated that the initial silence of the crowd turned into a cacophony, with every man present on his feet "or standing on a bench cheering his damned head off. They were ready to invade Hell, then. I personally,

\footnotetext{
${ }^{166}$ Codman, 270-74.

${ }^{167}$ Lande, 116-17.
} 
had never been so moved in my life." ${ }^{168}$ Prior to leaving England, Peter Joseph, a military policeman on duty at Peover Hall, where Patton kept his headquarters while awaiting his turn to fight the Germans in mainland Europe, remembered a speech filled with all the terrible language he was famous for, in which Patton told the crowd that if you see a coward, you shoot the coward so that they don't go home and breed more cowards. "But I had to admire the man, because he was what the people said about him a real warrior." ${ }^{\prime 169}$

For many who fought with Patton in World War II, these speeches were the only contact they had with their commanding general. Some, however, had the opportunity to meet him personally and nearly every one of these individuals knew well who he was before meeting him. Walter Unrath, a veteran who served in the Third Army, wrote, "In England...rumors were strong that our battalion would be part of the newly formed Army, which would serve under the legendary George S. Patton Jr., the one of Africa and Sicily fame. 'Old Blood and Guts' certainly did have an amazing reputation, and the GIs loved him.” Sergeant Davis, who was awarded the Silver Star Medal in Brittany during the early stages of Third Army's activation in 1944, commented: "I see Patton in my mind as clear as the first time I saw him at St. Lo.... He stood so straight - the picture of the perfect soldier. It was inspiring to us. We thought, here's a leader - up here with us and he's not afraid. If he can do it, I can do it."” Even before the ETO opened, Patton made an indelible impression on his soldiers. At Fort Benning, Georgia in 1941, a soldier in the $2 \mathrm{~d}$ Armored Division recalled that even though Patton was strict and demanding,

\footnotetext{
168 Ayer, 149.

169 Lande, 104.
} 
"He trained us hard in order to prepare us for what was waiting in our future - and was well liked by all the troops." 170

John E. Olson, a First Lieutenant in the $4^{\text {th }}$ Armored Division, remembered seeing Patton for the first time. "The first time I saw General Patton in person was when the $4^{\text {th }}$ Armored Division was going across on pontoon bridges that the $5^{\text {th }}$ Infantry [Division] built.... Even though I was some distance away, I could tell him easily by the ivoryhandled pistols as he stood in his vehicle. I don't know, maybe the Germans could tell it was him too." Olson was proud to have served under Patton. "I told the folks back home and they were impressed. When I got back home, it was kind of a distinction to have served under Patton.” Horace Woodring, Patton's driver when Patton was mortally injured in an automobile accident, remembered his initial encounter with Patton. "I was taking General Gerow to a meeting with Ike. Suddenly, here comes Patton - the horns were blowing and everything. Seeing him for the first time brought chill-bumps. We all knew what he had accomplished...."171

After the war and even later in life, veterans recalled the memories they had of the late General Patton and the stories they lived to tell were spoken with awe, tears, pride, and sometimes even joy and laughter. Patton touched the lives of many people throughout his life, such as the daughter of a restaurant owner in Chiriaco Summit, California, who recalled that her "father remembers him as a gentleman and a person who greatly respected the rights of others." While preparing for desert warfare at the Desert Training Center in 1941, Patton frequented the establishment and allowed his soldiers to do the same. Sergeant Davis visited Patton's grave in Luxembourg after the war.

\footnotetext{
${ }^{170}$ Ibid., 106, 8, and 13.

${ }^{171}$ Ibid., 251, 53, 70 .
} 
"Seeing the grave made me think of him in life. I could see Patton in my mind as clear as the first time I saw him at St. Lo. He was in his command car, a Dodge car with the top off, standing on the front seat and holding on to that windshield. His two pistols on his hips. He stood so straight - the picture of the perfect soldier. It was inspiring to us." Even though there were many soldiers and officers who had reason to dislike Patton, almost all of them remained loyal to him even after his death. "I had known a number of men who hated Patton," remembered W. King Pound of the $4^{\text {th }}$ Armored Division, "like one of the guys in our tank platoon who swears he would have killed him on sight. So I said to him, 'Well, you either hated Patton or you loved him. I loved him." ${ }^{172}$ Captain Abraham Baum is an example of one who had reason to despise Patton. Near the end of the war in Europe, Patton sent a small task force commanded by Baum to liberate a prisoner of war camp in which the Germans reportedly held Patton's son-in-law, Lieutenant Colonel John Waters. Fanatical German defenders nearly wiped out the task force and wounded and captured Baum during the raid. Patton later wrote in his journal that the only mistake he made throughout the campaign in Europe was to not send a larger force to Hammelburg during the raid. At the time, in March 1945, Patton "was the most popular and admired field commander since Ulysses S. Grant." Baum described Patton as far from being simply a selfish and cruel man; rather, his endurance, stamina, and uncomplaining nature along with his willingness to do more than was ordered endeared him to his soldiers. Patton, Baum argued, never tired of proving his courage to himself or his troops. Baum admired Patton and felt he was of no comparison to other Army commanders. He understood, like Eisenhower, that the war effort required

${ }^{172}$ Ibid., 295. 
Patton's service, even as the end of the war was nigh. During an exchange with Patton when finally rescued, Baum could tell the general was worried and he understood that Patton could get into serious trouble for approving the raid. Even though wounded and captured and with the majority of his troops killed, wounded, and/or captured, Baum wanted the general to understand that despite the raid's failure, Patton could trust his loyalty. ${ }^{173}$

From time to time, Patton was known to administer harsh verbal rebukes for indiscretions on the battlefield. Harry Semmes, who served under Patton during both World Wars, wrote in Portrait of Patton that it was "noteworthy that...the soldiers and the officers who served under Patton always bragged about the 'bawlings out' that they had received from him. They took pride in having been [bawled] out so wholeheartedly with such enthusiasm and energy. Instead of resentment, there were many tales about how tough the reprimand was [for] the storyteller." ${ }^{174}$ Patton once stopped his jeep to yell at a couple of soldiers moving prisoners. Directed at Al Neuharth of the $86^{\text {th }}$ Infantry Division, one of the two guards, Patton screamed, "'Get those fucking Krauts on their feet and moving, or I'll put you behind the same barbed wire they're headed for!'” Neuharth believed Patton was a master at staging temper tantrums, however. While his partner grumbled about what a son-of-a-bitch Patton was, Neuharth laughed and later recalled, "Of course, he was a borderline S.O.B. But he was a winner. He knew how to move 'em and win wars. I would have followed him nonstop all the way to Berlin on foot.... He's still a hero of mine. I've seen the movie Patton 11 times."175

\footnotetext{
${ }^{173}$ Richard Baron, Abe Baum, and Richard Goldhurst, Raid!: The Untold Story of Patton's Secret Mission (New York: Putnam, 1981), 11, 264.

${ }^{174}$ Semmes.

${ }^{175}$ Lande, 256.
} 
Perhaps the most notable example of one of these outbursts was when Patton berated and slapped two soldiers after the campaign in Sicily in 1943. Although Patton loathed seeing his troops badly wounded, he forced himself to visit them in the field hospitals and award Purple Heart Medals when possible. The task saddened him tremendously and he was prone to break down in tears, something he fought hard against in public, yet which came easily for the mercurial Patton. During the post-slappings apology tour, Major Ted Conway of the $9^{\text {th }}$ Infantry Division assembled with his unit in an olive orchard to hear General Patton speak and make amends. Mounting a platform in front of over 3,000 troops, Patton told the men to take their seats. "Patton started to give what we knew would be his apology. But he never got past the first word, which was 'Men!' At that point, the whole regiment erupted. It sounded like a football game in which a touchdown had been scored, because the helmets started flying through the air, coming down all over, raining steel helmets and the men just shouted 'Georgie, Georgie' - a name he detested." The bugler had to sound the call to attention, but that did not work. Finally, Patton "was standing there and he was shaking his head and you could see big tears streaming down his face and he said, or words to this effect, 'The hell with it,' and he walked off the platform." Everyone in the regiment stood at attention and saluted as General Patton mounted his command car, standing up in it and saluted back with tears still streaming down his face. "He was our hero. We were on his side. We knew the problem. We knew what he had done and why he had done it." Others echoed the sentiment, such as Leon Luttrell of the $2 \mathrm{~d}$ Armored Division who was in a field hospital recovering from wounds, the same hospital in which Patton slapped the first soldier. When Patton slapped the soldier and branded him a coward, Luttrell, speaking for 
himself and others present, recalled, "I can only say none of us felt sorry for the soldier.... I never heard anyone say that he [Patton] was not the great[est] leader, and best general in the Army.... I am proud to have served [under] General George S. Patton." 176 The troops rarely referred to Patton by his nickname "Georgie," a moniker used mostly by civilians or those outside his command. It is also notable that most of his troops also did not refer to him as "Old Blood and Guts," a term only used widely by the press. Some of his staff referred to him as "the General" in public, and "Georgie" in private. The fact that Patton's staff, those who worked most closely with him, referred to him by this familiar and affectionate nickname tells volumes about Patton and his caliber as a leader, particularly in view of his supposed underlying aloofness and truculence. ${ }^{177}$

Patton's strongest supporters were often the men who served under him, the soldiers who Patton was accused of bullying and abusing. After the slapping incidents, those who served with him in Africa and Sicily could not understand what all the fuss was about. One infantryman wrote home, stating, "'You can tell the folks back home that as far as I'm concerned Patton can slap the whole damn regiment, one by one, see? You know why? Because he knows how to fight, that's why. And we like guys who know how to fight." ${ }^{\prime 178}$ There were some detractors, however, particularly in the $4^{\text {th }}$ Armored Division who had profound loyalty to their division commander, Major General John Wood. Eugene W. Luciano recalled that his Commanding General spoke in front of troops to another general serving as an umpire during the pre-war maneuvers and who gave the division bad marks on their tactics. The umpire stated the tactics used were not

\footnotetext{
${ }^{176}$ Ibid., 90-91.

177 Allen, 26.

${ }^{178}$ Pearl, 106-7.
} 
doctrine. "General Wood never took a back seat to anyone, not even General Patton" and Wood "endeared himself to his troops for standing up for them." According to Luciano, this boldness on Wood's part probably got him dismissed in December 1944 by Patton, who reportedly said Wood needed a rest after a similar confrontation between the two. In contrast, Luciano asserted that Patton was reckless with the lives of his troops, which cost the $4^{\text {th }}$ Armored in terms of casualties. ${ }^{179}$

An infantryman in the $5^{\text {th }}$ Infantry Division recalled the bloody battle for Metz in autumn of 1944. In his recollection, military strategy and superior officers encouraged Patton to not attack Metz (although Bradley and Eisenhower ordered the operation). From this foot soldier's perspective, Metz should have been flanked, encircled, or bypassed, but Patton could not pass up such a tempting target. Fortress Metz had not been conquered by assault since 451 A.D. and this soldier held that Patton was determined to add to his historic drive by taking it down, even if it cost him every man in the Third Army. With 43 forts in two defensive rings around the city, there was more than enough firepower and manpower to put up a solid defense. Patton displayed callousness in this instance by ordering the officers of one company to keep moving and disregard the casualties: Patton would get them replacements. "The cold-hearted bastard actually said this in front of all of us!" While Patton was not entirely pleased with the performance of the $5^{\text {th }}$ Infantry Division at Metz, the feeling was reciprocal: many in the $5^{\text {th }}$ Infantry Division were a little less sanguine with Patton's performance during the offensive. Indeed, the men of this unit were further embittered as the division that relived them, the $95^{\text {th }}$ Infantry Division, were later dubbed the "Iron Men of Metz" even though

\footnotetext{
${ }^{179}$ Eugene W. Luciano, Our Blood and His Guts!: Memoirs of One of General Patton's Combat Soldiers (Chapel Hill, NC: Professional Press, 1995), 32-33, 69.
} 
they lost much of the ground gained earlier by the $5^{\text {th }}$ Infantry Division. ${ }^{180}$ This soldier's perspective was representative of the dissatisfaction of a lower-ranking soldier who did not have a clear overall picture, but what many men did not realize is that Patton's operational methods resulted in fewer casualties than any other Army in the ETO. Yet, others under Patton's command understood what he did and why. The $8^{\text {th }}$ Tank Battalion Commander, Albin Irzyk, recalled an encounter when Patton came to see the unit and described the positive impact the visit had on his troops. Having little to say to Irzyk, Patton stood in the passenger side of a jeep as it sped to where Irzyk stood before the driver slammed the vehicle to a screeching halt. "This was vintage Pattonthe showman, the headline grabber, the press favorite, the flamboyant Army General but also the Army Commander esteemed and held in awe by his men as we would very soon see." Patton talked to each of the men present, asked a personal question of them, and offered a word of encouragement, appreciation, compliment, wisecrack, or goodnatured ribbing, thereby establishing instant rapport with Irzyk's soldiers. They "were literally eating it up. It was a master at work."181 Irzyk went on to say

I was amazed at the tremendous impact that one man could have on a body of men. After his visit, troopers of the $8^{\text {th }}$, already a tired group, worked furiously all day, as with renewed energy. The men, as they would and as expected, talked about nothing else all day. The visit was a great morale booster. There was no question that the Army Commander knew who they were, what they were doing and what they had achieved. He had indicated his appreciation and approval of their efforts. There is almost nothing in the world like recognition and pride and we were handed a big dose of both this day. I was amazed and will always remain amazed at the Patton who visited us. ${ }^{182}$

Just hearing about the visit sent waves of excitement through the $8^{\text {th }}$ Armored Battalion and the word spread like wildfire, "faster than a hot rumor. The visit of old 'Blood and

\footnotetext{
${ }^{180}$ Bilder and Bilder, 152, 58, 73.

${ }^{181}$ Albin F. Irzyk, Patton's Juggernaut: The Rolling 8-Ball (Oakland, Oregon: Elderberry Press, Inc., 2017), 227-28.

${ }^{182}$ Ibid., 228. See also interview by Nathan C. Jones, 2018, Oral History.
} 
Guts' to THEIR battalion became the exclusive topic of conversation at each of the mess trucks that evening." 183

Despite some grousing among some soldiers in the rank and file, many more felt having been under Patton's command was a point of pride. Chester Smith, an artillery officer in the $94^{\text {th }}$ Infantry Division, recalled letters written in the field that he reviewed as a censor: "Sometimes people that'd write those letters saying how wonderful Patton is would go outside and bitch about him to each other. Didn't like him. They'd say, 'He's not looking out for us. He's giving us too much risk.' But when they'd write home, they'd brag, brag, brag. They'd say, 'I'm a Patton man!'” Smith was clearly enamored by Patton, as many were. "He was what all the books say about him. He was arrogant, demanding, magnificent. Everybody adored him, even though sometimes they couldn't stand him." 184 These men were proud of their connection to their general. They seemed to want to be a warrior like him, or at least thought of as such.

One wounded soldier going through physical rehabilitation in New York had but one ambition: "to get back and to be again under [Patton's] command." While much was made about Patton's discipline, "it was one of the greatest things for the morale of the men. They all felt themselves a little bit better" than other troops and swore by Patton as a leader and as a man. ${ }^{185}$ Perhaps Jan Curtis, a Red Cross hostess assigned to Third Army, put it as succinctly as one could when she remembered, "you'd hear a lot of the

\footnotetext{
${ }^{183}$ Albin F. Irzyk, A Warrior's Quilt of Personal Military History (Raleigh, NC: Ivy House Publishing Group, 2011), 230.

${ }^{184}$ Lande, 6-7.

${ }^{185}$ Letter, Everett L. Crawford to General Patton, in The George S. Patton, Jr. Papers (Library of Congress, November 13, 1944).
} 
GIs say, 'His guts and our blood.' Some resented it, but I think they were proud to be part of it all."186

Often, when soldiers wrote home telling loved ones about their attitudes towards Patton, those back home wrote Patton directly to tell him. Rose Barton, the fiancée of an artilleryman in Patton's Third Army, felt compelled to tell Patton that she "never heard him brag about anyone but he certainly thinks the world of you and your strategy in military affairs" and that she was "proud that my boyfriend is serving under you and will march behind you when walking thru [sic] Berlin."187

The results of Patton's demanding and dominating personality go beyond rational explanation. He attempted to shape in his image the soldiers who served under him and infuse in them his aggressiveness, sense of destiny, and pride. Even those critical of Patton were not too proud to capitalize on his name and fame. One book written by the son of a common infantry soldier using memoirs and interviews as evidence, detailed a common critical view of Patton. Patton only appeared in this particular narrative sporadically and there is not much commentary on Patton himself outside of some criticism regarding the operation to take Metz. Yet, the book was titled A Foot Soldier for Patton: The Story of a "Red Diamond" Infantryman with the US Third Army. Included in the pages was the image of a memorandum of commendation from Patton to the $5^{\text {th }}$ Infantry Division as well as scathing criticisms on several of Patton's decisions. While many accounts of Patton were hypercritical, paradoxically they also made it a point of pride to have a connection to him.

\footnotetext{
186 Lande, 176.

${ }^{187}$ Letter, Rose La Barton to GSP, in The George S. Patton Papers (Library of Congress, January 7, 1945).
} 
Many other memoirs, however, illustrated a favorable opinion of Patton and although the authors said less about Patton than their own war experiences, his name still made it in the title. For example, Frank W. Martin's Patton's Lucky Scout recounts his time on special assignment to Patton's Third Army headquarters, his daily duties, and some anecdotal stories that add color to the narrative. While it is apparent that Martin and Patton had frequent, if not daily, interactions as a superior and subordinate, theirs was a cordial relationship. Martin volunteered for the duty, looking to learn about war from the greatest warrior he knew. ${ }^{188}$ Similarly, Thomas W. Clarke chronicled his experience as a machine gunner in the Third Army under the command of Patton in George S. Patton's Typical Soldier, a book dedicated to "all those who served under General Patton in the Third Army and to his granddaughter, Helen Patton-Plusczyk," who wrote that Patton "would have loved the title!" According to Clarke, General Patton was a powerful figure and decisive commanded - the soldiers under his command were constantly aware of his presence, both physical and psychological. Clarke asserted Patton was personally brave and he admired courage and bravery from those whom he commanded. His soldiers trusted him and were inspired by the fact that he was always in the thick of battle - Patton was never reluctant to get his hands dirty and get down in the mud when the occasion demanded it. For many soldiers like Clarke, Patton was indeed an inspirational and empathetic leader who led his troops into battle, and he made sure his troops saw him do it. ${ }^{189}$

\footnotetext{
${ }^{188}$ Frank Wayne Martin, Patton's Lucky Scout (Milwaukee, WI: Crickhollow Books, 2009), 1.

189 Thomas W. Clarke, George S. Patton's Typical Soldier: A Memoir of Thomas W. (Wally) Clarke, Company D, 101st Infantry, 26th Division, Third Army (Lancaster, PA: American Historical Pub., 2009), xix.
} 
Robert Orbach, a field artillery officer in World War II, wrote his memoir titled Not All Hell: Two Hundred Sixty-five Days in General George Patton's Third Army. In it, Orbach recounted the one time he met Patton at a river crossing where Patton barked orders to break up a traffic jam. Asked if he had anything to do with the debacle, Orbach told Patton no. "And that, gentle readers... is how I met the famous General George S. Patton." ${ }^{190}$ For those who only met or saw Patton once, no matter for how short a time or from what distance, that vivid memory remained embedded in their minds. Nat Frankel told of one such instance, an encounter that lasted ten seconds, but "the memory of those ten seconds continues to haunt my life as if it had been a thousand years. I could have been married to the goddamn guy, that's how forceful the encounter was and that's how persistent its memory." Stalled in an intersection on the way to Bastogne during the Battle of the Bulge to relieve the surrounded $101^{\text {st }}$ Airborne Division, Frankel was forced to deal with Patton's rage. "'Goddamn! This is not time to get stuck! Get this goddamn thing rolling!"” was Patton's directive to the terrified tanker. Frankel went on to describe his intuitive impressions of Patton:

When I think of George Patton, I think of a huge rock cut and angled in numerous directions. You can't tell its real shape.... Patton's greatness was not something we figured out in 1946. We knew it before Bastogne, and everyone in the Third Army knew it. And yet we had mixed feelings about him.... We took Patton's grandstanding with a grain of salt. In fact, there was an expression floating around the Third Army whenever Patton's nickname, Old Blood and Guts, was mentioned. We'd say, 'Yeah, our blood and his guts.' Yet what is so telling is the fact that we knew that he was playing up to an image, yet we respected both him and the image at the same time. It was, after all, a stunning image, and there must have been something real underneath it that enabled him to play it so well... It may be that there was enough of the actual stuff in him, the real blood and guts, to override evidence of his normal humanity. But I think it was also because we needed to be led by a George Patton. We needed to believe so badly that the fact that he was at all times playing some sort of a game with himself and with us didn't ultimately matter... We were inspired by him; inspired in the old sense that there was a noble general astride a white horse.... We knew he was a bastard, but we were moved by the grandeur, not to mention the fear, his presence generated - and we respected the extraordinary lengths to which he was willing to go to maintain and promulgate his own image. ${ }^{191}$

\footnotetext{
${ }^{190}$ Orbach, 104.

${ }^{191}$ Frankel and Smith, 39-43.
} 
Ask any World War II veteran what he did during the war and it is likely he will tell you something about his branch of service, unit, or theater, maybe a battle or two unless he served in North Africa, Sicily, or the U.S. Third Army. Then you are likely to hear a terse "I was with Patton." Why did these men identify themselves with General Patton so personally? Because Patton demanded that all under his command knew who he was and wanted each of them to be shaped in his image. ${ }^{192}$ Patton's nephew recalled, In my own experience, if I asked a soldier what was his outfit he would almost invariably answer by [r]egiment or at most, by [d]ivision. He scarcely ever answered by [a]rmy, except in the case of the Third. Then the almost invariable reply was, 'I'm with Patton.' My first encounter with this form of pride had been over coffee at the snowbound Stephensville Airport in Newfoundland. The sergeant seated next to me wore the blue " $\mathrm{A}$ " shoulder patch of the Third and a splendid shiner. I asked him what had happened. 'Very simple, sir. Some ignorant bastard of a soldier told me Patton was no damned good. You ought to see what's left of his face.' Since that day to this, it has been my experience across this country, in talking to lawyers and bank presidents, stevedores and bartenders, to have them reply with prideful memory of loyalty: 'I was with Patton. ${ }^{193}$

John McCloy, the Assistant Secretary of War, visited the ETO in the fall of 1944 and remarked to Patton, "Whenever we stopped in the territories of the other army commanders and asked the men to identify their units, they invariably referred to their battalions or regiments. Most of them didn't even mention the divisions to which they belonged. But the moment we entered your territory, George, the men spoke of themselves as members of the Third Army - and you should have seen the look in their eyes whenever they said it."194 Secretary of War Robert Patterson visited hospitals in the United Kingdom and found it easy to immediately identify members of the Third Army. In asking patients about their units, those of other armies gave their division or regiment and very few even knew what army they belonged to, much less the name of its commanding general. But almost without fail, a Third Army man always replied, "I was

\footnotetext{
192 Lande, 6.

193 Ayer, 161.

194 Rosevich.
} 
with Third Army," and he not only knew who commanded it, but usually had a personal anecdote about Patton. ${ }^{195}$ Both during and after the war, these soldiers not only took pride in their personal battlefield accomplishments and those of their army and commander, but also wanted others to know that they fought with Patton, in their view, a proven winner. They relished the idea of being a winner and being associated with a winner. Because of Operation Fortitude, the deception plan that kept Hitler confused as to where the main body of Allied troops was to land during the invasion of mainland Europe, many soldiers in Normandy still did not have on shoulder patches that identified their division affiliation. Private W. King Pound of the $4^{\text {th }}$ Armored Division recalled a time when his unit rolled past some "doggies" [infantrymen] and asked who they were. “Georgie's Boys," came the reply. ${ }^{196}$

The braggadocios Patton, with all his apparent flare, fiery and motivational speeches, and commanding presence on the battlefield, were not enough by themselves to create such a distinct and closely tied identity between Patton and his troops. Patton not only made them feel like winners, he actually led them to many victories, which bolstered their confidence. While it was easy for some to see why Patton's enlisted men loved him and some of his officers occasionally hated him, all were loyal. Patton was a winner. ${ }^{197}$ First Lieutenant Nathan A. Allen, a supply officer for the $109^{\text {th }}$ Ordnance Company of II Corps, relayed the impact Patton had on events when he took command after the disastrous Battle of Kasserine Pass in February 1943, a fight that ultimately saw the Germans rout American troops in an embarrassing defeat. Sent to take command of the

\footnotetext{
${ }^{195}$ Allen, 32.

${ }^{196}$ Lande, 121.

${ }^{197}$ Ayer, 227.
} 
defeated and demoralized corps, Patton's presence there, in part, resulted in a complete change in attitude amongst the troops. They suffered no more setbacks and obtained considerably more equipment. His soldiers began to believe that Patton's word and reputation carried weight - that he said what he meant and meant what he said and achieved the results he promised. ${ }^{198}$ Ernie Mrazz recalled hearing other veterans talk about Patton in glowing terms while listening to their stories about Patton and his brand of discipline, but "the fellows who served under him thought a lot about him. I always admired the way he got things done." 199

Others, such as Fred Hose, a warrant officer on Patton's staff, stated of Patton: "This man, his thinking was prolific. Like any really intelligent man, he was two steps ahead of everyone else's thinking. I've often thought that if it wasn't for the slapping incident, Patton would have to have been given charge of the Twelfth Army [Group] instead of Bradley." ${ }^{200}$ Even though they later downplayed Patton's role in the Allied success, during the war General Bradley rated Patton as the best army commander in combat in the ETO and General Eisenhower considered Patton the most valuable of the seven Allied army commanders. ${ }^{201}$

Aside from his ability on the battlefield, Patton, contrary to popular conception, attempted to view situations through the eyes of others and knew that units were living things with a spirit, which further endeared him to his troops. According to Vince Gish of the $6^{\text {th }}$ Armored Division, Patton understood the relationship camaraderie had with unit

\footnotetext{
${ }^{198}$ Lande, 45.

${ }^{199}$ Letter, Ernie Mrazz to Milton F. Perry, in Patton Archives (General George Patton Museum, September 23, 1954). See also Artifact File CCN 45980.

${ }^{200}$ Lande, 207.

${ }^{201}$ Rickard, 322-23.
} 
morale. Patton arranged that any man wounded who returned to combat would do so by returning to his original unit, a gesture not lost on his men. Bill Jennings, a military police (MP) officer with the $819^{\text {th }}$ MP Company in XX Corps "admired his total disregard for danger of the incoming shells and for his bearing and genuine helpfulness to do a job, regardless of who I was." Alvin H. Kruse mused, "The legend about Patton's policy of being with his men on the front lines are not exaggerated." Once when visiting the $94^{\text {th }}$ Infantry Division's front lines, a German machine gunner "put about 12 rounds of fire through the door" that Patton just entered, missing Patton by no more than a foot. Patton's tankers and infantrymen noticed that he shared hardships and dangers with his troops, something rare for a general officer of such high rank. ${ }^{202}$

Many soldiers understood that the Patton persona was a fabrication. Rather than being the hard-driving, crass, and carelessly aloof elitist who treated his subordinates as marionettes that Patton's detractors wanted others to believe, the mass majority of those who served under Patton experienced something else. Sergeant Phillip Robbins of the $80^{\text {th }}$ Infantry Division described Patton as "solicitous, rather friendly, and ate the C rations we offered him and his companions." Another veteran, Emil J. Schmidt of the $26^{\text {th }}$ Infantry Division, understood that the Patton image was "showmanship on his part." When talking to Patton, he did not come across as the same man who cursed and cajoled on stage when he spoke with ordinary soldiers. As far as the famous speeches go, soldiers, long known throughout history for colorful language, were not offended in the least. Schmidt, like many others, knew that Patton used that form of speech to impress his men and stoke their enthusiasm for combat. Patton was a great showman and the men

${ }^{202}$ Lande, 138, 86, 241. 
liked him, explained John Houk, an Army Air Corps radio operator who was taken to meet Patton after Germans shot down his B-17 bomber over France, and described Patton as "very reserved, almost shy." Jack Spratt, the ball-turret gunner on the same airplane, recalled Patton was "just like an old country gentleman, a grandfatherly type you could easily converse with.... He was the kind of leader that people just wanted to follow." L.G. Spillman, the tail gunner, described Patton as an impressive individual who made the crew feel at ease when they met. Carl Ulsaker of the $95^{\text {th }}$ Infantry Division asserted, "For all the publicity about Patton's posturing and bragging, I found him to be a practical leader who understood what motivated soldiers and who put it to them in terms they could understand...." During one of Patton's speeches, Ulsaker recalled how as the word passed up and down the columns of men, the posture and expression of every soldier changed dramatically as their confidence renewed. "We had them licked, by God. That pistol-packin', swaggerin', Hun-killin' son of a bitch had just said so in unmistakable terms!" George Godding, a battalion commander in the $90^{\text {th }}$ Infantry Division, remembered casually speaking with Patton on the battlefield. There was none of the ranting and raving that a lot of people attribute to him. There was nothing antagonistic. No intimidation or trying to impose his four stars on me. He talked man to man. General Patton had an ability to talk with people on the ground and always bring you back to the basics of infantry.... He ended up sounding a lot like a teacher talking to his students.... Of course we listened closely. There was intense interest by all present, because he had proven himself. This man's leadership was why we were where we were. We had a lot of confidence in him. ${ }^{203}$

Patton was by no means universally loved, yet even those who disliked him took a certain pride in being able to state that they had served in the Third Army. As previously noted, the moniker "I was with Patton" was a common reply when asked what outfit Third Army veterans served in during the war. Whether the tales of those who served

${ }^{203}$ Ibid., 145, 56-7, 71-73, 232, 36. 
under Patton will endure beyond the lifespan of the last World War II veteran is uncertain. But in the immediate aftermath of the conflict, more than one unsuspecting solider or civilian paid the price of a black eye or broken nose for having insulted Patton or those who served in the Third Army. Men who ranged from bank presidents and corporate lawyers to truck drivers and car salesmen shared a common bond of having been Patton men. Although most agreed that Patton was not perfect, the personal flaws of the man did not change the unique sway he held over his soldiers. ${ }^{204}$

Other than Patton's family, those who knew him best were those who worked closely with him on a daily basis, namely his staff. Beginning in 1947, seven different former staff officers wrote at least nine books about Patton, the Third Army, and their war experiences, attesting to Patton's popularity with these men and the respect they had for him. Although mostly containing obsequiously glowing reviews of their commander's performance and personality, these works were not completely without criticism. For example, Robert S. Allen, who served in a key role in the G-2 (intelligence) section of Third Army headquarters, wrote Lucky Forward as the first of such books. In Allen's war memoirs, he complained how Patton let Hugh Gaffey and Hobart Gay, the Third Army Chief of Staff and Assistant Chief of Staff respectively, run Patton's staff with little interference, which, in Allen's view, led to unfairness as those two, according to Allen, were petty and played favorites. Allen also contended that Patton needlessly withheld his promotion to Colonel. ${ }^{205}$ Regardless, Allen wrote Lucky Forward as an operational history, of sorts, of the Third Army in the ETO during World War II. The book contained obvious overtones of a Patton admirer's attempt to place the

\footnotetext{
${ }^{204} \mathrm{D}^{\prime}$ Este, $812-14$.

${ }^{205}$ Allen and Rickard, 78, 169.
} 
general in a first-person context. As a self-proclaimed "true narrative," Allen's book did much to illustrate the ways in which the Third Army took on the persona of its dynamic commander.

Lucky Forward began in England prior to the June 6, 1944 invasion of Northern France with a brief prelude regarding Patton's background and personality. Throughout the book, Allen explained how Patton's seemingly erratic behavior was for show, an attempt to be easily recognizable to his troops. Allen claimed that the Supreme Headquarters Allied Expeditionary Forces (SHAEF) had a consorted aim to extinguish the Patton legend, a futile and unnecessary effort built on envy. Clearly the author was a Patton acolyte. Allen claimed it was SHAEF, not the German enemy, who presented the largest challenge to Third Army's success. While Allen pointed out the shocking level of incompetence of the headquarters staff above Third Army, he was not shy about claiming excellence among Patton's loyal crew. An obviously partisan work, this book regaled readers with tales of glory while placing blame for the Third Army's shortcomings squarely upon higher headquarters. ${ }^{206}$

Harry Semmes was a Patton protégé and personal friend of his since World War I and wrote $A$ Portrait of Patton, published in 1955 . Semmes served as a company commander in Patton's tank battalion during the Great War, and even spent time next to Patton in a field hospital after being wounded in the Battle of the Meuse-Argonne in September 1918. Semmes served under Patton again during World War II, and included in his book vivid, nostalgic anecdotes that illustrated Patton as a flamboyant individualist, feared by the men he battled and idolized by the men he commanded. Semmes spoke to

\footnotetext{
${ }^{206}$ Allen.
} 
the admiration Patton's soldiers had for him and how most loved serving under him, hinting towards the attitude followers had of the general and how they identified personally with their commander.

Semmes asserted that what many people viewed as arrogance was really Patton trying to put the United States in higher standing, particularly during the Tunisia and Sicily campaigns. This attempt to gain prestige for the United States was misinterpreted as a rivalry between Patton and British Field Marshall Bernard L. Montgomery, who Semmes claimed, was merely a symbol of England in Patton's estimation. Furthermore, Semmes veered from the norm by asserting that Patton's formula for success on the battlefield was not just discipline (although he does state Patton was a strict disciplinarian) and tactical genius - Americans wanted to have a leader willing to be at the front. Semmes made a point to reveal unknown aspects of Patton as a military man as well - his empathy as a leader, sympathy for wounded soldiers, and his penchant for allowing subordinates to take the spotlight. Like most early Patton biographies, there were glaring omissions. For example, Semmes said almost nothing about the slapping incidents, nor did he mention that John Waters - his son-in-law - was actually shot by Americans attempting an ill-fated rescue mission (the Hammelburg raid) designed by Patton himself. There are some falsehoods as well, such as the declaration that the Cadillac Patton rode in during the crash that caused his fatal injuries was driven away, which are seemingly innocent when taken singularly, but added fuel to conspiracy theories.

Other books written by former staffers lent to the understanding of Patton in the context of identity, memory, nostalgia, legend, and myth and indicate the resiliency of the 
Patton legend as they spanned the course of 48 years. Charles Codman wrote Drive (1957); Paul Harkins, Third Army Deputy Chief of Staff, wrote When the Third Cracked Europe (1969); Charles Odom, Patton's physician, wrote General George S. Patton and Eisenhower (1985); Richard Stillman of the G-3 (Operations) section wrote General Patton's Timeless Leadership Principles (1988), General Patton's Best Friend (2001), and General Patton's Secret Missions (2005); C. Cabanné Smith of the Engineer Section wrote My War Years: Service in General Patton's $3^{\text {rd }}$ Army Staff (1989); and Oscar Koch, Patton's Chief of Intelligence wrote G-2: Intelligence for Patton (1999). Each one of these works was similar to the next in that they portrayed Patton in a positive light while attempting to remain objective by bringing out some of his flaws. None of the books, however, were overtly negative towards Patton and given the nature of the authors' status while serving under him these books allowed readers to understand the interpersonal dynamics of Patton's headquarters, leaving the impression that Patton was demanding but fair and a winner whom nearly all believed would lead America to victory.

As the saying goes, a first impression is a lasting impression. Almost every individual who served on Patton's staff who later wrote their recollections of first meeting Patton described profound experiences. Describing Patton's appearance upon first impression, for example, Stillman recalled how Patton's immaculately tailored uniform was a sight to behold. "His Cavalry background was apparent - gleaming leather boots, pink riding breeches, Eisenhower-type jacket with brass buttons, shiny helmet liner, necktie and swagger stick." Stillman described Patton's pistol with leather belt and brass buckle, military decorations, overseas stripes, and the eighteen stars that 
adorned his uniform and accessories. "With his tall, trim figure, this man appeared bigger than life to me. The general was about to tell us what to expect under his command. Believe me, he got our immediate attention." 207 Smith recalled in his memoirs the time he first heard Patton speak to his staff at Knutsford, England.

According to Smith, Patton

called the staff together and made a speech. This was our introduction to our new general. He was a tall, fine physical specimen...but he had a high squeaky voice. Perhaps because of this he cursed a great deal. In his talk he said that every man likes to fight and [every] man reached his greatest heights on the battlefield and that 'we will hit the godamned Germans with a sock full of shit and when we wiped them out we will go over there and get the purple-pissing Japs.' Why they pissed purple no one knows. The language went on for quite a while. It made an extremely bad impression on me, and, as we walked away, the officers I talked with all thought we had gotten the bottom of the barrel with this general. I want to say here that his first adverse impression did not last long, and I ended up having great admiration for him. By the time we were in combat, I would rather have served under him than any other general. He built up an esprit-decorps in the Third Army that was far superior to that of any other army. ${ }^{208}$

Patton was not just a favorite among many staff officers, but also the press corps for more reasons than one. Those who worked around Patton understood why he garnered as much media attention as he did and grew accustomed to having war correspondents around Lucky Forward on a regular basis. Patton filled gaps in the news cycle with positive stories when good news was necessary for the morale of the troops and Americans back home. Wherever Patton was, things happened. Correspondents knew it and followed Patton when and where they could. ${ }^{209}$

Patton insisted that his staff officers visit the front lines daily and held himself to that same standard. Codman recalled, "It was not easy being the General's aide, nor safe, either, because the General was always up front during combat and was exhilarated when

${ }^{207}$ Richard Joseph Stillman, George S. Patton's Timeless Leadership Principles (New Orleans, LA: Richard Stillman Co., 1998), 8-9.

${ }^{208}$ C. Cabanne Smith, My War Years: 1940-1946. Service on Gen. Patton's Third Army Staff (Houston, TX: Rosenlaui Publishing Services, Inc., 1989), 33-34.

${ }^{209}$ Oscar W. Koch and Robert G. Hays, G-2: Intelligence for Patton (Atglen, PA: Schiffer Military History, 1999), 153. 
exposed to fire." Patton understood that a good leader must get the feel of the troops to lead them, to know how much farther they can carry on, something that could only be done by looking at their faces. ${ }^{210}$ In doing so, Patton exposed himself to more danger than most general officers. Any increase in the size of his successive commands and the added weight of his responsibilities did not lead to a proportional increase of prudence. Codman revealed that

In France he has been, on the whole, content with the ordinary occupational risks incidental to daily visits to the front line by peep [jeep], i.e. road accident, sniping, strafing, bombing, and return flights to Army Headquarters - often at twilight, sometimes after dark - in small unarmed liaison planes, his theory being that the Commander should always be seen going to the front, never coming away from it. What with the relatively infrequent gamble for gambling's sake such as the jaunt into no man's land...I believe this type of chance-taking springs from a need, a compulsion on the General's part to compensate for the almost unbearable sense of frustration induced by enforced inaction and passivity. ${ }^{211}$

Lending to Patton's adamancy of being recognized amongst the troops on the front line through his brand and showmanship was also a set of canned speeches for specific instances, which he numbered. After one such speech, a staff officer asked Patton where the unit he referred to in the speech came from, "the one from the part of the country that produces fighters." Patton replied that he did not have the slightest idea; it "was just Speech Thirty-three." ${ }^{12}$ Although there is only one known recording of one of Patton's speeches, a few soldiers who heard the other more famous ones firsthand later transcribed them. They were all similar in most aspects. Filled with expletives, Patton intended to speak the soldiers' language even though he hailed from a wealthy family and was himself soft-spoken, well read, and classically educated. Noted for the shock value they provided, those who remembered the speeches later recalled the immediate and

\footnotetext{
${ }^{210}$ Codman, xii, xvii.

211 Ibid., 187.

${ }^{212}$ Ibid., 94.
} 
lasting impression the talks had upon them. The speeches, however, were not the only instances that Patton used crass language to stun audiences. At a dinner party in England while waiting to be activated to fight in Europe, Patton surprised and entranced his female host when she asked about the ideals for which he fought with a terse, "I, dear lady, have been fighting all my life and hope to continue indefinitely to do so for the simple reason that I love fighting." 213

Patton became a celebrity who achieved international prominence as a military leader during World War II, and as such, entertainers such as Bob Hope, Marlene Dietrich, Bing Crosby, Dinah Shore, and Doris Duke who came to perform for his troops always wanted to spend time with him. ${ }^{214}$ Patton's staff officers noticed how these theater people seemed to have a lingering effect on the General, inciting him, unconsciously, to outperform them. Leaving a dinner party still weak from laughter, one visitor remarked, "That guy in there, all by himself, without benefit of high-priced writers, music, or scenery - that guy is EIGHT-EIGHTY ENTERTAINMENT."215

Most historians and biographers inaccurately explain Patton's behavior by attributing to him a sense of insecurity as a result of an alleged case of dyslexia. Citing poor spelling throughout his life and the fact that Patton failed algebra his first year at the U.S. Military Academy, this assertion is pure conjecture, one initiated by some of the earliest Patton biographers and perpetuated by subsequent writers. The word dyslexia was first used two years after Patton was born and children with language difficulties were not diagnosed as dyslexic until the mid-twentieth century. ${ }^{216}$ These historians made

\footnotetext{
213 Ibid., 141.

214 Stillman, 124-25.

${ }^{215}$ Codman, 182-83.

216 "History of Dyslexia," http://www.dyslexia-aware.com/dawn/history-of-dyslexia.
} 
the unfortunate mistake of psychoanalyzing an historical figure based on an assumption and they did not explain why Patton received exemplary marks in mathematics a semester after failing the course. His failing was likely due to the fact he took French and algebra classes the same semester, two subjects he was not particularly strong in, and while he received a high grade in French the semester he failed algebra, the following semester when he passed algebra, Patton nearly failed French. Poor study habits or time management were more probable culprits. Additionally, Patton was never tested for or diagnosed with the disorder. However, Patton did have some insecurities, namely that of his high-pitched voice and weak jaw line, which he considered to be effeminate. Speaking to his aide-de-camp, Patton exclaimed, "I wish to hell I had a real fighting face.... You are either born with a fighting face or you are not.... Having practiced for hours in front of the mirror, I can work up a fairly ferocious expression, but I have not got, and never will have, a natural-born fighting face." And there lay the general's unresolved problem - how to reconcile the fighting soldier and the gentleman. ${ }^{217}$

The effects of Patton's showmanship were not lost on those closest to him. Patton "made Seventh Army personnel different from other boys and in the end they were proud of the difference," wrote one staff officer. ${ }^{218}$ Patton's tendency to be dominating, yet not domineering, explained, as told by another officer close to Patton, why some staffers called him "Georgie" in private. Although he was typically reserved and aloof but in combat violent and ruthless, "hundreds of thousands of men served under him with boastful pride and truculent devotion." This obsequious staff officer described Patton as

${ }^{217}$ Codman, 275.

${ }^{218}$ Ibid., xiii. 
"quite a man," "superb," and exclaimed how he had never seen nor ever would witness an equal. ${ }^{219}$

It did not hurt that Patton was likeable, at least reported by those who best understood him. And he was a winner, something every soldier was happy to be associated with. As such, most accepted the uncomfortably disciplined approach Patton brought to soldiering. "They did not like it [wearing wool uniforms with sleeves rolled down], but I did not speak to a single soldier who had a thing to say against the General. He had projected himself everywhere and he had created morale, which, as they used to say back in Plattsburg [an officer training location], was a main essential of leadership." ${ }^{220}$ Apparently there were many hardships that soldiers were willing to endure so long as they believed their commander would lead them to victory.

Those who worked closely with Patton during World War II had another reason to like him. Seeing a different side of Patton's humanity, these men recognized the façade Patton put on to cover his true nature and understood its importance for the war effort. "Beneath the rugged exterior which he worked hard to preserve even in this period of inactivity [in Palermo after the slapping incidents], there was beneath the surface, a passionate gentle man who was a delight to listen to as he poured out his innermost feelings," wrote Patton's personal physician. ${ }^{221}$ Contrary to popular conception, Patton "was partly a realist and partly a sentimentalist, and anything he put into personal terms was only to illustrate his explanations of the principles of combat. In fact, he did not give me the slightest impression of personal vanity." Rather, Patton was at times kindly and

\footnotetext{
${ }^{219}$ Allen, 12, 25, 95, 98, 148.

${ }^{220}$ Codman, xiii.

${ }^{221}$ Charles B. Odom, General George S. Patton and Eisenhower (New Orleans, Louisiana: World Picture Productions, 1985), 17.
} 
considerate. ${ }^{222}$ Others who merely saw glimpses of the true Patton during visits quickly recognized the Patton paradox as well. Bob Hope and Frances Langford visited Patton's headquarters on one occasion, and a staff officer noted that Langford's screenwriter was fascinated with Patton. Hope commented that Patton "was not the Old Blood and Guts I've heard about"' when Patton showed his sentimentality as he spoke of his soldiers and their suffering and was modest about the role he played in the successful campaign in Sicily. Patton was indeed mercurial in more ways than one. Sentimental and romantic, serious and professorial, braggadocios and self-deprecating, audacious and calculated, Patton also had "that amazing capacity for instant rightness and lucid anger. It's a rare and invaluable quality.... You can't fake it. You either have it or you haven't." The inestimable virtue of making others fighting mad was at times necessary to get soldiers to undertake the unnatural task of killing other human beings. ${ }^{223}$

The soldiers and officers who served under Patton were not the only ones in the ETO who respected Patton. Time magazine ran an in-depth story about Patton and his image appeared on the cover with a caption that read: "Third Army's Patton. The enemy has reason to fear him."224 One captured German general described Patton as "the most modern, and the only, master of the offensive" in the Allied armies. "Patton is the most dangerous general on all fronts. The tactics of other generals are well known and countermeasures can be affected against them. Patton's tactics are daring and unpredictable. He fights not only troops opposing him, but the Reich." 225 No person on

\footnotetext{
${ }^{222}$ Codman, xvii, 192.

${ }^{223}$ Ibid., 115, 24-25.

224 "Untitled," TIME April 9, 1945.

${ }^{225}$ Allen, 31.
} 
Patton's staff understood the effect his actions had upon the enemy better than his intelligence chief, who recalled

Patton commanded great respect, from friend and foe alike. Enemy commanders would surrender only to General Patton in person. To be taken by a great field commander apparently added a certain dignity to an otherwise ignominious situation. His presence in theaters would be regarded by the enemy as a foreboding of things to come. Where Patton was and what he was doing was of constant interest to the enemy high command. ${ }^{226}$

All of the thespianism Patton exhibited throughout the war was for naught if he was unable to produce positive results on the battlefield. Patton's superiors put up with his antics because he was successful. General Eisenhower knew that the services Patton provided were indispensable to the war effort, as evidenced by his reluctance and unwillingness to send Patton back to the states after the slapping incidences in Sicily and his Knutsford media gaffe. "The General knows exactly what he is doing, and if at times the higher staffs turn green around the gills when across their astonished situation maps flash the prongs of seemingly unprotected spearheads launched deep into enemy territory, it is only because they have yet properly to gauge the man's resourcefulness." As for his subordinates, they learned that he rarely, if ever, let them down. In adversity, Patton was always able to find a solution and the men saw him up front to ensure that subordinate commanders applied his solution. ${ }^{227}$ Patton's skill, courage, and loyalty were the qualities that made him a hero to his men and enabled him and his soldiers to achieve the glory Patton sought. ${ }^{228}$

Because his successes on the battlefield were undeniable, even considering critiques made by some historians who noted that the enemy Patton faced was not as capable as in other areas of operation, those under Patton's command were willing to

\footnotetext{
${ }^{226}$ Koch and Hays, 155.

${ }^{227}$ Codman, 159-60.

${ }^{228}$ Allen, 32.
} 
endure the methods he imposed to achieve those results. Major Frank Pajerski in the intelligence section recalled, "He [Patton] always appealed to me - liked his idea of spit and polish. If you're going to soldier, you get up and soldier. None of this sloppy business." Like many others, Pajerski knew he was with a winner. ${ }^{229}$ For Patton, ironclad discipline was the cornerstone to an effective military unit, and while uncomfortable for the troops under his command, his methods worked. "Patton seemed to be everywhere as Third Army units were fighting in four directions.... Whenever possible, he would walk to front line units and talk with the soldiers. His positive attitude and physical fitness were an inspiration to everyone. ${ }^{.230}$

Very few of Patton's superiors actually liked him, and in fact many seemed envious as evidenced in the war memoirs of Eisenhower and Bradley. But, they were grateful for his services and respected his ability, making it easy for them to deal with his peculiarities. Patton seemingly fought two wars while in Europe in World War II: "one against the enemy and one against higher authorities for the opportunity to fight the enemy. His brilliant victories in both fields did not endear him to most of his superiors. ${ }^{.231}$ Eisenhower and Bradley spent time after the war downplaying Patton's contributions to the war effort and trumpeting their own, and yet it was Patton "whom the Allies called upon to take command when the situation was bleak and uninviting.... His accomplishments in moving men and supplies as the Third Army rolled across Europe would become one of the legends of World War II." ${ }^{, 32}$ Even staff officers from higher headquarters knew that Patton was the media darling. "Patton's stature has increased

\footnotetext{
${ }^{229}$ Lande, 103.

${ }^{230}$ Stillman, 24.

${ }^{231}$ Allen, 28.

${ }^{232}$ Koch and Hays, 147.
} 
immeasurably in this campaign and everyone has a far higher regard for him than they did in Sicily," recalled Colonel Chester Hansen, a staff officer for General Omar Bradley's $12^{\text {th }}$ Army Group. ${ }^{233}$

General officers amongst the Allies understood the immense popularity Patton enjoyed in spite of internal politics and wounded egos. General L. L. Lemnitzer, British Field Marshal Harold Alexander's Deputy Chief of Staff at the Headquarters of Allied Armies in Italy, wrote after Patton made the media gaffe in Knutsford, England regarding who was going to "rule the world" after the war, that his "remarks seem harmless enough to me and I dare say, if any other General had made them, they would have gone completely unnoticed." In Lemnitzer's estimation, the press seemed to be "gunning for George, which, in my opinion, is nothing short of criminal." Lemnitzer and Alexander agreed that the success of the Sicilian campaign was in large part due to Patton's unrelenting drive, ability, and personal leadership. That such a valuable general should be sacrificed for a minor incident was beyond comprehension for those who knew him and saw him in battle. For better or for worse, Patton was what the war effort required. "What is needed now is good leadership, and he [Patton] has a lot of it."234

It can be difficult for people, particularly those with a high level of military authority, to reciprocate admiration with their subordinates. Yet Patton's romanticized view of the martial arts led him to do just that, and his troops fit nicely into his archaic, chivalric notions of warfare. Patton was known to deliver rousing speeches to his soldiers and put his wounded troops on top of his sentimental pedestal. Decorating one

\footnotetext{
${ }^{233}$ Lande, 189.

${ }^{234}$ L. L. Lemitzer, "Exerpt of a Letter from Brig. Gen. L. L. Lemnitzer," in George Patton Papers (Library of Congress, May 21, 1944).
} 
unconscious soldier with a mortal wound as he lay on a cot and wearing an oxygen mask, for example, Patton "pulled one of those quick switches of his - took off his helmet, knelt down, pinned the medal on the pillow, whispered in the guy's ear - stood up at attention. Elementary if you like, but I swear there wasn't a dry eye in the house, and - as you know - hospital doctors, nurses, and interns are not the most impressionable people in the world." In another instance, Patton gave a short speech that elicited a prolonged ovation. His opening line as he stepped up to the microphone was, "'there are certain moments and this is one of them - when I think that possibly I've not been such a sonuvabitch [sic] as I thought I was."” Patton delivered four minutes of electrifying homage to the American doughboy and ended with, "'the American enlisted man in this campaign has accomplished the impossible against the unspeakable."” Afterwards he admitted, "I hadn't the slightest idea what I was going to say....as a matter of fact, what did I say?" Codman told Patton what he said during the speech and that anything prepared beforehand would not have been nearly as genuine. Codman knew better than anyone Patton's truest feelings towards his men and his staff, his generosity and the doting upon his subordinates, and the vitriol with which he lashed out when he felt his men did not receive the credit he believed they deserved. Humbleness or humility were quite possibly never adjectives used to describe members of the U.S. Third Army, and Patton once exclaimed that his soldiers were not cocky enough. "Let the world know what you are doing, otherwise the American soldier will not be appreciated at his full value."235

On June 7, 1945 Patton made a triumphant return to the United States, first landing in Boston for the first of three public appearance that were part of a bond drive

\footnotetext{
${ }^{235}$ Codman, 111, 17, 264.
} 
tour to raise money for the war effort. While being greeted by a roaring crowd, an honor guard, and a seventeen-gun salute, Patton embraced his family while cameramen captured the emotional details. Flags fluttered in tribute along the twenty-mile trek as young women threw flowers at Patton who stood in an open car and waved at a crowd estimated at one million cheering people. Driven through a shower of confetti thrown from downtown Boston high-rises, the car delivered the returning hero to the Hatch Shell outdoor concert venue in the Charles River Esplanade where he addressed another crowd of over fifty thousand. The following day he flew to Denver where he delivered another speech and then on to Los Angeles and Pasadena. There he was again shuttled through massive crowds, an estimated million and a half people lining the streets, along with a vast military victory parade of war vehicles and marching troops, veterans groups, and bands. One hundred thousand spectators crowded into the Coliseum to see Patton and General Jimmy Doolittle and hear their addresses, which were for many disappointingly short. ${ }^{236}$ Detractors found reason to criticize Patton, as he was apt to say things that were easily taken out of context, misunderstood, or blatantly misrepresented. Regardless, the public showing at these events illustrated the immense popularity Patton enjoyed amongst the American people writ large near the war's end, a sentiment that grew to immense proportions since the beginning of the war. ${ }^{237}$

As demonstrated, General Patton was popular amongst his soldiers, staff, and war correspondents and it was these individuals who helped spread the legend and Patton's popularity. They eventually went back to the United States and carried with them

\footnotetext{
${ }^{236}$ D'Este, 746-48.

${ }^{237}$ Quoted from The New York Times, June 8, 1945 page 6 and The New York Times, June 10, 1945 page 20 in Linenthal, 43.
} 
sanguine and propitious attitudes of their former commander and spread those convictions into the public. The legend did not need to be started from scratch as Patton's celebrity preceded those men and women. The dramatic sweeping maneuvers of the armies Patton led across North Africa, Sicily, and France drew banner headlines day after day on the American, English, and French home fronts. The name George S. Patton, Jr. became as familiar to American schoolchildren as the name George Washington. Patton was one of the most well-known American heroes of the war, and even the unfortunate publicity he received in Sicily was mostly forgotten or forgiven. ${ }^{238}$ A few oral histories demonstrate this popularity, but the colossal amount of fan mail Patton received best illustrates how the public generally felt about this colorful and audacious figure.

Charles Codman tallied and classified incoming mail as letters of protest and letters of support made their way to Patton's headquarters. Even after eliminating communications from personal friends of the General, the results were overwhelmingly positive for Patton: 89 percent were supportive of Patton's effort while only 11 percent were negative reactions to a handful of bad press releases. Codman argued that the "voltage" of his personality, in particular, endeared Patton to many Americans and "was potent enough to galvanize hundreds of mothers, fathers, grandparents, wives, sisters into pouring their hearts out on paper," referring to "the voluminous mail which flooded our headquarters at Palermo after the two soldier-slapping incidents." The publicized version of Patton was very different from his true character and was, to be sure, skewing the data dramatically, but that belies the point: for their part, the public genuinely respected,

${ }^{238}$ Pearl, 123. 
adored, and appreciated him. There was very little middle ground. Codman recalled,

"Every letter was either for the General or against him." As he explained,

The letters of protest in many cases both obscene and anonymous confined themselves to ringing the charges on 'You are a cowardly so-and-so for striking an enlisted man.' The pro-General letters, mostly from relatives of servicemen, also bore a close resemblance one to another. 'I want you to know we are proud our son is serving in your Army,' a typical letter ran. 'From the newspaper accounts we are not clear as to exactly what you did and why, but we want you to know we are for you. Keep going and God bless you. ${ }^{239}$

Codman referred to a Gallup poll taken immediately after news broke about the slapping incidents in Sicily that indicated slightly less favorability towards Patton, but those numbers later balanced out with Codman's calculations. Taken as a whole, it formed quite an illuminating documentation of the swings of public opinion towards an officer who had "the rare quality of making people want to fight."240 Patton enjoyed seeing himself in newspaper headlines, but what he enjoyed most was the knowledge that service members under his command, past and present, felt the way they did towards him as told by their loved ones. ${ }^{241}$

Many soldiers who served with Patton during the First World War followed Patton's exploits with a great deal of interest, such as H.M Hutchinson whose only wish was "that I was with you as I was in 1918."242 Tom Bush, a self-described "great admirer" of Patton, the only general he followed, lamented that he attempted to enlist and fight under Patton, but the "big shots" denied him because of his age. ${ }^{243}$ Many of the messages from former doughboys were event driven, such as a Christmas card sent to Patton from World War I veterans of the $829^{\text {th }}$ Aero Squadron. On the card, they drew a

\footnotetext{
${ }^{239}$ Codman, 270-74.

${ }^{240}$ Ibid., 134-35.

${ }^{241}$ Letter, Patton to Charles H. Thomas, in The George S. Patton Papers (Library of Congress, undated).

${ }^{242}$ Letter, H. M. Hutchinson to Patton, ibid. (March 31, 1943).

${ }^{243}$ Letter, Tom Bush to Patton, ibid. (undated).
} 
picture of Patton and two doughboys having a conversation, with one saying he "sure would have liked to have served under Patton!" but then admitted while he was too old to fight he was "on the cheering section of the side lines." More than just a quick note, these men thought enough of Patton to take time to personalize their message. Like all such correspondence, Patton kept it for posterity. ${ }^{244}$ One of Patton's former sergeants, Alfred Crease, kept a scrapbook highlighting Patton's successes in World War II and included fond memories from the Great War and sent his wishes for the best of luck in his letter of encouragement. Clearly, the positive impact Patton had upon these men lasted for years and their connection to and memories of their former commander remained strong over the interwar years. ${ }^{245}$

Similarly, many service members sought assignment to fight under Patton, such as Captain Paul McConihe of the Marine Corps who wanted to be part of the "accomplishment and magnificent spirit of your command...."246 Nonmilitary-aged gentlemen on the home front who had no connection to Patton or the military at all wished they could take part in Patton's well-publicized operations. Fifty-seven-year-old J. E. Powers of Portland, Oregon, lamented, "Oh, how I wish I could be with you," but he was too old for military service. "Hit them and hit them hard...I am glad to have that kind of man to direct our forces.... Go at it he-man."247

Obviously, former World War I doughboys were not the only fans of Patton, and most never had any personal connection to him at all. A group of teenaged boys in a Sunday school class told Patton, "We admire your fighting spirit" and knew that his

\footnotetext{
${ }^{244}$ Christmas Card, C.J. Hammond to Patton, ibid.

${ }^{245}$ Letter, Alfred Crease to Patton, ibid. (January 22, 1945).

${ }^{246}$ Letter, Captain Paul McConihe to Patton, ibid. (May 9, 1943).

${ }^{247}$ Letter, J.E. Powers to Patton, ibid. (March 15, 1943).
} 
knowledge of tank warfare would lead the United States to victory. Often, as in this case, the writers solicited some sort of memento from Patton such as a signature or photograph. ${ }^{248}$ John. H. Mulkeen, a thirteen year old student in Brooklyn, New York, asked not only for "a keep sake" because he admired Patton as he "read in the newspaper how you won all the battles," but also wanted Patton to "make Hitler dance to the tune of your six guns when you get a hold of him."249

School-age children chose to memorialize or commemorate Patton in unique ways, such as the seventh graders at Public School 161 in Brooklyn who named themselves the General Patton class with the slogan "Pattern your life after Patton." They followed Patton's exploits and participated in bond drives to help the war effort. ${ }^{250}$ A fifth grade teacher, upon being asked by her students, allowed them to pass around a letter, each student writing a short note to Patton for Christmas. The teacher added her wishes to the children's notes, stating, "General Patton, you are a very great hero to these $5^{\text {th }}$ grade children.... They are very proud of you and of the record you are making as are we all." ${ }^{251}$ Jack Brown gave a speech at a church in Kansas at Thanksgiving about Patton, his hero. In the audience was the mother of two soldiers under Patton's command who sent a copy of the speech to Patton along with Jack's picture. Ever the teacher, Patton wrote to Jack directly, and commended him on his masterful use of the English language and thanked him for his interest. Patton was never too busy to reply to his fans:

\footnotetext{
${ }^{248}$ Letter, Capital View Methodist Church Sunday School Class to Patton, ibid. (March 21, 1943).

${ }^{249}$ Letter, John H. Mulkeen to Patton, ibid. (May 26, 1944).

${ }^{250}$ Letter, Harriet Nelson to Patton, ibid. (December 1, 1944).

${ }^{251}$ Letter, Room 3 Class to Patton, ibid. (undated).
} 
this particular correspondence occurred during the waning days of the Battle of the Bulge. $^{252}$

Other teachers used Patton as an example in the classroom. James Bowman, a seventh-grade teacher at Benjamin Franklin Junior High School in New Castle, Pennsylvania, taught "boys and girls who are of the 'hero-worshipping' age," who were "inspired by the leaders in all walks of life, [but] never being able to come in contact with them." He found a "visual means of framing this necessary educational contact, which inspires the best in the lives of pupils" by exhibiting the autographs of the great people in all fields of endeavor. These young baby boomers were thoroughly inundated with Patton lore, which they undoubtedly carried with them into the next American generation. $^{253}$

Many children took it upon themselves to write to their hero. Ralph Pitts, a 15 year old from Rockford, Michigan wrote to Patton that he heard how the Americans were "fighting the Jerries right in their own back yard" and how they must have "spirit and REAL leadership to make a show like that!" Inspired by Patton, Pitts said that he wanted to join the Army when he was old enough, wanted to fight for Patton, and donated blood so "possibly one of your men may live." 254 Patton responded that Ralph "will probably get a chance for this war, at least by the time we have to destroy the Japanese, and I shall certainly be glad to have you with me, because it is a fine thing for a young boy to want to be a soldier." 255

\footnotetext{
${ }^{252}$ Letter, Patton to Jack Brown, ibid. (February 7, 1945); Jack Brown to Patton, ibid. (January 9, 1945).

${ }^{253}$ Letter, James A. Bowman to Patton, ibid. (August 20, 1943).

${ }^{254}$ Letter, Ralph Pitts to Patton, ibid. (March 26, 1943).

${ }^{255}$ Letter, Patton to Ralph Pitts, ibid. (May 10, 1943).
} 
Ten-year-old Billy Richardson of Upland California met his hero at the Desert Training Center while Patton was there preparing units for desert warfare and "was so proud to know you then. Now after your great victories in Africa and now in Sicily, I am so happy.... I hope to see you some day after you win the war." Patton responded on August $10^{\text {th }}$ that he "can assure you that I remember you in the desert last year" and "shall try to live up to your idea of me." ${ }^{256}$ Besides habitually answering every letter he received, Patton often obliged those who asked for autographs, particularly requests from children. One 14-year-old boy from Charleston, South Carolina wrote to ask for an autograph "if you are not too busy winning the war" and received an autographed picture of the general. ${ }^{257}$

Some children sent presents to the general. One young boy, ten-year-old Robert Patton Makielski wrote, "I know how great you are and collect your pictures as they come in the newspapers \& know all your nicknames." Included with the letter were several pictures he drew, one a picture of Patton as a soldier carrying a rifle with bayonet chasing Hitler and "Shooting Hitler in the seat of his pants." A testament to the popularity of his moniker, the letter was addressed simply to "Blood and Guts, Somewhere in Italy." The letter found Patton who replied to thank Makielski for the "beautifully illustrated" letter: "I can see that your Patton ancestry is coming to the front." Patton signed his response as "Your affectionate Cousin."."258 Of course, the two were not related.

${ }^{256}$ Letter, Patton to Richardson, ibid. (August 10, 1943); Billy Richardson to Patton Letter, ibid. (July 15, 1943).

${ }^{257}$ Letter, William R. Cheek to Patton, ibid. (August 19, 1943); Patton to Cheek, ibid. (September 24, 1943).

${ }^{258}$ Letter, Robert Patton Makielski to Patton, ibid. (October 15, 1942); Patton to Robert Patton Makielski, ibid. (November 1, 1943). 
Patton was very gracious in his replies, especially to praise from children. Patton was twelve-year-old Sonny Hill's "favorite general" because the army commander was "tough." If all generals were like Patton, "the war wouldn't last but a few days. I think you'll live up to your nickname Blood and Guts. [General Mark] Clark is having all the glory now but if you were there you would have twice as much." Patton replied with thanks for the kind remarks "about my fighting ability which, when I next go to battle, will serve as an inspiration to me."${ }^{, 259}$

Idolization of Patton was not exclusive to school-aged boys. Young girls such as Betty Drake wrote to Patton, who was "proud of a General like you" and wanted Patton to write back "so I can tell all my friends that Gen. Patton is my friend," and signed her note "Your Best Friend." Patton wrote back saying that he appreciated her kind thoughts and that letters from home "are always a source of pleasure and inspiration."260 The mother of a two-year-old girl wrote, "For a long time [her daughter] recognized your picture in magazines and newspapers. She has never chosen another name except 'Patton' for her dolls. She is expecting a doll for Christmas this year and says its name will be 'Patton.' When we ask her where Patton, as she calls you, is, she answers, 'He's in Sicily."” Wishing Patton a Merry Christmas from their entire family, they assured Patton, "we're all for you 100\%."261

Adults in the United States also wrote and sent letters of encouragement and support to Patton. Theodore Stillwell of Ephrata, Pennsylvania wrote to Patton as "an average American citizen, who having read a great deal about you and your military

\footnotetext{
${ }^{259}$ Letter, Sonny Hill to Patton, ibid. (December 19, 1943); Patton to Sonny Hill, ibid. (December 10, 1943).

${ }^{260}$ Letter, Betty Drake to Patton, ibid. (October 6, 1943); Patton to Betty Drake, ibid. (November 1, 1943).

${ }^{261}$ Letter, Mr. and Mrs. Lee Fry to Patton, ibid. (December 7, 1943).
} 
career, feel sure that we here at home can depend upon you to do a great deal in the job you are now doing" and wanted Patton to know that "we here at home will try and back you up 100\%." ${ }^{262}$ Because of his constant appearance in the news, many American citizens felt that they began to know Patton personally. Miss Mary June Krieger of Harrisburg, Pennsylvania believed "that we folks back home in these States do not consider your men strangers. Maybe we have never seen you, perhaps we shall never have the opportunity to see you even upon the return to this country, but it is this way: we read so much about you that sometimes I guess we are practically forced to think we know you." ${ }^{263}$ Some individuals like E. Garland Brown came to Patton's defense and took it personally when "some infernal damnable draft-dodging, glamour sissie tried to reflect" on Patton poorly. "However, I think a vast majority of the American people have forgotten your defects and short-comings, and to-day you are American's most beloved and worshipped soldier." ${ }^{264}$

Some of Patton's greatest supporters were the parents of troops under his command. One such mother of a soldier who was "only one hundred and fifty pounds, but it is all fighting Irish," wanted Patton to know "he won't fail you, any more than you did America." Parents such as this one were proud their sons served under him and must have been ecstatic when Patton wrote back. To Mrs. Elizabeth Maguire, Patton wrote back that her son was in "one of the finest Regiments of the finest Division of the finest

\footnotetext{
${ }^{262}$ Letter, Theodore R. Stillwell to Patton, ibid. (March 20, 1943).

${ }^{263}$ Letter, Mary June Krieger to Patton, ibid. (May 25, 1944).

${ }^{264}$ Letter, E. Garland Brown to Patton, ibid. (April 27, 1945).
} 
Army in the world and that I am sure he is doing a good job. You should be proud to be the mother of such a boy."265

More than one child born during the war in the United States bore the name of their parents' military hero. One soon-to-be father wrote Patton to ask for "the great honor" for permission to name his son "George Patton Myers." He wanted "to name him after some great living person that would inspire him to live up to the greatness of the man whose name he bears." Patton, in turn, was clearly flattered by the sentiment. ${ }^{266}$ One mother named her son after Patton and sent him a photograph of her child. Patton reciprocated and sent an autographed photo of himself, which she placed over her son's bed. "Nothing is valued more in my home than the photo of my number one hero. Little Patton, I'm sure, will treasure your photograph in years to come, as I treasure it now."267

One bereaved mother wrote how her son who was killed in action while with the 2d Armored Division in North Africa "loved you and his buddies...very much and enjoyed working under you.... And my prayers to God daily is that he will guide and protect you...in carrying on where my precious boy had to leave off.” Patton was touched by the woman's sincerity and wrote back, "Please accept renewed expressions of my sorrow of the death of your son.... It is a fine thing to realize that men whom one has trained are so fond of one, and to think that the mother of such a man, who made the supreme sacrifice, has taken the trouble to write his old commander."268

\footnotetext{
${ }^{265}$ Letter, Patton to Elizabeth Maguire, ibid. (April 14, 1943); Mrs. Elizabeth Maguire, ibid. (March 10, 1943).

${ }^{266}$ Letter, Mr. and Mrs. Donald Myers to Patton, ibid. (December 7, 1944).

${ }^{267}$ Letter, Patton to Fincher, ibid. (January 29, 1944); Lucille Fincher to Patton, ibid. (February 26, 1944).

${ }^{268}$ Letter, Patton to Mrs. Apple, ibid. (September 10, 1944); Mrs. S. M. Apple to Patton, ibid. (August 12, 1944).
} 
Another mother wrote a heart-wrenching letter telling Patton she "admired the wonderful inspiration you have been to our boys and even before my son went into the Service I had hoped some time he would be under your leadership..." Her son was overseas for only three months when killed in action. Tragically, he never received her letters even though she wrote every day, but he never complained and loved the Army "as long as it lasted," and was confident in officers "like yourself who give the boys confidence in themselves." She went on to say, "we heartbroken mothers all admire" Patton. Empathetically, Patton wrote back, "I cannot tell you how deeply your letter moved me. It was so human and yet so heroic. America will always be successful when it has such mothers as you." 269

As part of his romanticized vision of war and warfare, Patton had a penchant for understanding the soul of a combat unit. He made a policy of releasing information to newspaper columnists about units involved in combat operations (an uncommon act during the war) with the idea that soldiers liked to see credit being given to their organizations. Patton argued that Axis forces already knew whom they fought as soon as they saw unit insignia on American uniforms. A father of one of Patton's soldiers in the $95^{\text {th }}$ Infantry Division expressed his appreciation to Patton for publishing the "names of divisions and units under your command" in the newspapers, which allowed parents to follow the location of their sons. "Your thoughtful policy in this regard...make parents proud that you are the commander of their sons in action in the Third Army.",270

Although a steady stream of letters poured into Patton's headquarters from U.S. citizens throughout World War II, when Patton's name was in newspaper headlines

\footnotetext{
${ }^{269}$ Letter, Patton to Rubretz, ibid. (May 8, 1945); Mrs. George E. Rubretz to Patton, ibid. (April 20, 1945.).

${ }^{270}$ Letter, Leo Stalnaker to Patton, ibid. (December 6, 1944).
} 
admirers flooded the military mail system with messages of support. While there were some letters of admonishment from concerned citizens after the slapping incidents, the Knutsford gaffe, and after Eisenhower fired Patton as Commander of the Third Army when he ignored the postwar denazification program, at the same time there remained a majority of positive correspondence. For example, after the slapping incidents in Sicily, Mrs. Henry Godfrey, who had a son in Patton's command and "was a great admirer" of Patton, wrote that she knew he was "a good Christian and that is why I am so grateful that my boy is under your leadership." ${ }^{271}$ The mother of an infantryman in the $378^{\text {th }}$ Infantry Regiment wrote to thank Patton "for guiding the $95^{\text {th }}$ Division so well while they were part of your famous Third Army."272

"You're still our general in spite of hell and high water," wrote Colonel D.B. Sanger of the Army War College in Washington, D.C. after the slapping incidents. ${ }^{273}$ Paul F. Ferreira sent a Christmas card, writing in it, "If your critics turned on themselves the same guns they 'fire' at you, none could survive. You are a mighty soldier. Time contains many surprise packages. ${ }^{274}$ Others offered their words of encouragement during times of crises as well. Mrs. Frank Unger of Honolulu, Hawaii sent a poem she cut out from a newspaper "written especially for you" and dedicated to General Patton. "We all need 'morale boosting" from time to time. The poem included in the letter had a stanza reading "We mothers who have placed our sons in your lead and care, Feel you will not let them down...carry on, is the prayer of a mother."275

\footnotetext{
${ }^{271}$ Letter, Mrs. Henry Godfrey to Patton, ibid. (November 8, 1943).

${ }^{272}$ Letter, Mrs. Charles H. Thomas to Patton, ibid. (April 7, 1944).

${ }^{273}$ Christmas Card, Col D.B. Sanger to Patton, ibid. (undated).

${ }^{274}$ Christmas Card, Paul F. Ferreira to Patton, ibid. (1944).

${ }^{275}$ Letter, Mrs. Frank J. Unger to Patton, ibid. (December 29, 1943).
} 
Mrs. Henry McLain of Alameda, California wrote to Patton that it must be difficult to be "handicapped by the willful stupidity of the people that could use a wellplaced slap to open their eyes to reality. If it were in my power I would see that you were made President of these United States.... This has not been a pretty world and it takes a man that has been through the worst of it to see and know what is wrong and what to do about it." For many people, Patton's faux pas were trivial and there should not be "so much time and effort wasted on things of so little importance."276 Elias Van Slyke agreed. "I think you got one of the lousiest deals in the history of the country or the Army" and found it difficult to believe that someone jealous of his success wanted to reap the glory. Van Slyke was certain Patton would be revered the same as Lincoln and Grant and "I believe in you and so do a hundred million others."277

After the slapping incidents, media coverage of Patton eventually became nonexistent as public sentiment cooled. One concerned citizen who had not heard any news about Patton "decided to write you and find out for myself." She was "an admirer of yours for a very long time. You're a symbol of courage and a soldier who won't be forgotten. I have spoken to many soldiers who have served under you and they say you're the best." Needing the encouragement and ever glad for reassurance, Patton wrote back, stating he was "interested to hear what the soldiers think of me, and I am so glad when you write that all of my men, whom you have met, like me."278

Probably the most unique and heartfelt letter Patton received after the slapping incidents came from Thomas Sharkey who "was like that soldier you slapped. I wish to

\footnotetext{
${ }^{276}$ Letter, Mrs. Henry McLain to Patton, ibid. (April 29, 1944).

${ }^{277}$ Letter, Elias Van Slyke to Patton, ibid. (undated).

${ }^{278}$ Letter, Ruth Irene Daspit to Patton, ibid. (April 7, 1944); Patton to Daspit, ibid. (May 4, 1944).
} 
God you had of slapped me. Maybe I wouldn't be home now in my shame." Sharkey found a way to get out of the war by citing shellshock and described his own actions as "cowardly," but insisted that he was not the same pusillanimous soldier any longer. "I've been ashamed ever since my release in 1943" and begged Patton to find a way to get him back into the Army and under his command. ${ }^{279}$

After Patton's previously discussed gaffe regarding the power makeup of the post-war world made at Knutsford, England, General Eisenhower nearly fired Patton once again. Although he retained his command, frankly because even Eisenhower knew the war in Western Europe could not be won without him, Congress denied Patton's promotion to the permanent rank of Major General for a time. During World War II, the U.S. Army found it necessary to promote individuals beyond their current rank, thus creating a dual promotion system that consisted of permanent and temporary rank. Prior to the D-Day landings on the beaches of Normandy, although he wore the three stars of a Lieutenant General, in the official military record Patton was a Brigadier General. Many citizens found this to be an injustice.

One concerned citizen wrote his U.S. Senator, Robert R. Reynolds of Texas, urging him to confirm Patton's appointment to the permanent rank of Major General after the Knutsford incident. For E. Garland Brown, "self-appointed military experts" were wrong to hold up the promotion. If Britain, the U.S., and Russia were not going to rule the post-war world, "what is this war about? Are we Americans going to sacrifice everything and then permit Hitler, Mussolini, or Tojo to rule the world?" Brown expressed "the sentiment of a great majority of those that are really, actually sacrificing

${ }^{279}$ Letter, Thomas Sharkey to Patton, ibid. (May 31, 1945). 
to win this war" when he said, "Patton is the real soldier of this war. And the sneering, jealous, would-be great cannot dim his brilliant leadership by their jealous outbursts." Brown implored Reynolds to "come to [Patton's] defense and permit him to go on and win the war, regardless of the jealousies of the 'mugwumps' that Hitler loves." 280

An excited voter who was mistakenly certain Congress was going to have a Republican majority after the next election wrote to his U.S. Senator, asking what was the matter with those "stuffed tomatoes you hob nob with that they don't give him a little promotion." Patton was popular with his soldiers who were "for him, lock, stock, and demi-john." As the "only Republican constituent that you have I want you to shake a leg and get Patton his rights. When we have a real go getting scrapper like him we should do right by him. Out the winder [sic] with the old sodbusters.... You know the [W]est was won by two-gun toters." Republicans did not win a majority in Congress in November 1944, but if his Congressman didn't "stiffen up," he was "thinking of promoting Patton for Senator. Hot Patutie, wouldn't he rock em?"281

Others blamed the press for the unfavorable treatment Patton received. "We have a lot of faith in your ability, and think you were very unjustly treated by some of the press in the country which you are doubtless big, and strong enough to over-look, and not let it trouble you." Yet there were plenty of publications that were pro-Patton, such as the opinions of the Pony Express Courier, a San Francisco publication, which explained the paper was on Patton's "gallant side, and pulling for your continued, and glorious success." The newspaper editors asserted, "We are not defending General Patton because

\footnotetext{
${ }^{280}$ Letter, E. Garland Brown to Senator Robert R. Reynolds, ibid. (May 8, 1944).

${ }^{281}$ Letter, E Garland Brown to Senator Carl Hayden, ibid. (August 10, 1944).
} 
he needs no defense." His record "is sufficient to overcome any detail, right or wrong...."282

Patton's presence in England in early 1944 was part of a successful operation intended to deceive the Germans of the nature and location of the impending invasion of mainland Europe. Codenamed Operation Fortitude, Patton's part was to play the role of an Army Group Commander, replete with fictitious units and inflatable tanks and trucks. Prior to his arrival in England, Patton went on a site-seeing tour of the Mediterranean, causing confusion for German intelligence officers who were concerned of the location of whom they considered the Allies' most formidable army commander. During the tour, news reports suddenly ceased. For some, the lack of news regarding Patton during Operation Fortitude was unbearable. The public scoured the papers "for a few lines that might give a hint as to where" Patton was located, but "when success was rampant in Brittany silence could endure no longer."283

Generally, Patton received fan mail steadily but at times of great success or after one of his mistakes it came in waves. For example, millions of Americans were glued to the papers, latching onto any piece of news of Patton and his Third Army as they raced across France after the breakout from the hedgerows of Normandy. Walter Anderson and his wife backed Patton " $100 \%$ " and had the upmost faith in his leadership abilities. ${ }^{284}$ Mrs. Louis Stricker wrote Patton to assure him "that your admirers are in great numbers" and was grateful for his accomplishments. She "used to listen to that unspeakable

\footnotetext{
${ }^{282}$ Letter, Therese S. Jose to Patton, ibid. (April 23, 1944); Therese S. Jose, "Editorial," Pony Express Courier December 1943.

${ }^{283}$ Letter, Grace Maud Mason to Patton, in The George S. Patton Papers (Library of Congress, August 19, 1944).

${ }^{284}$ Letter, Walter Anderson to Patton, ibid. (August 20, 1944).
} 
Pearson person [who leaked the news about the slapping incidents] but after his crucifixion of you I have ceased to do so.” Mrs. Stricker wished Patton would give Pearson "a poke in the nose.... If I were a man, I would have done it myself." Patton's response, in his usual dry wit, was better than the one that caused the stir with Pearson in the first place when he replied, "I agree with you in some of the wishes expressed, but I fear that the restrictions of military service will not permit me to carry out the operation. ${ }^{285}$

For better or for worse, Patton did enjoy seeing himself in the headlines. This was understandable as most headlines were flattering. And he had many fans that reminded him of his successes. Citizens sent him newspaper clippings along with their congratulations and adulations. To one such individual, Patton replied that he shared "the pleasure in seeing other people eat crow," the ones who thought him detrimental to the war effort. ${ }^{286}$ Indeed Patton's detractors had much crow to eat during the Allies' darkest hour - the German offensive in the Ardennes Forest in December 1944 - as Eisenhower called upon Patton who turned the Third Army 90 degrees to the north after disengaging with the enemy in order to attack the left flank of the German Army during the Battle of the Bulge. Soldiers of the encircled $101^{\text {st }}$ Airborne Division in Bastogne, Belgium and their families back home were particularly thankful Patton was still in the fight. One brother of a soldier who helped stop the German onslaught while in Bastogne wrote Patton thanking him for rescuing his younger brother. ${ }^{287}$

\footnotetext{
${ }^{285}$ Letter, Patton to Stricker, ibid. (September 1, 1944); Mrs. Louis J. Stricker to Patton, ibid. (August 15, 1944 ).

${ }^{286}$ Letter, Patton to Mr. Walter B. Stewart, ibid. (September 5, 1944).

${ }^{287}$ Letter, Theodore Macejko to Patton, ibid. (Library of Congress, January 31, 1945).
} 
Like many school-aged children, adults also chose to commemorate Patton in unique ways, such as D.V. Irvin who followed Patton's troop movements and activities with great interest. Irvin kept a scrapbook filled with pictures of Patton. ${ }^{288}$ As did Mrs. Fraser Henry's mother, who saved clippings from the papers and who knew "that with men like you, [the war] just can't last too long." ${ }^{289}$ Ira Jackson sent a poem about Patton that the New York Dispatch published and Clifford Mayfield of Jacksonville, FL, a twelve-year-old in the seventh grade, wrote a song about Patton and the U.S. $7^{\text {th }}$ Army. ${ }^{290}$ Fred Jackson of New Britain, Connecticut composed “General Patton's March: Hoist the Colors!" and dedicated the song to his hero. ${ }^{291}$ In addition to the purely patriotic, these creative types showed their support for Patton in unique ways. Often, concerned citizens appealed to a higher power on Patton's behalf, such as Mrs. Logan. "Personally, GEN Patton," she wrote, "I want to thank you for your marvelous sacrificial leadership. You are bearing a terrific responsibility and to be sure there is a self-effacement in it all. We all do thank you and praise God for such a leader. I pray for your physical and mental stability as well as for the wisdom from on high that is merciful in these terrible days. And so remember someone is remembering you at the throne of grace." ${ }^{292}$

Patton was not just an American phenomenon: he had his devotees in Europe as well. Although of no relation, Grahane A. Patton of Wellingborough, England was wellversed in Patton lore - he knew about Patton's world record in the Stockholm Olympics target shooting qualifying event, his "narrow escapes at Casablanca and now much more

\footnotetext{
${ }^{288}$ Letter, D.V. Irvin to Patton, ibid. (Library of Congress, July 14, 1943).

${ }^{289}$ Letter, Mrs. Fraser Henry to Patton, ibid. (July 13, 1943).

${ }^{290}$ Letter, Ira Jackson to Patton, ibid. (July 22, 1943); Clifford Mayfield to Patton, ibid. (undated).

${ }^{291}$ Letter, Fred Jackson to Patton, ibid. (September 6, 1944).

${ }^{292}$ Letter, Mrs. John Logan to Patton, ibid. (July 27, 1943).
} 
recently" in Sicily, and considered General Patton a "namesake inspiration" to the writer. "Now, West Pointer, the Axis has, thanks to your leadership, felt the Patton punch!"293 Miss E. F. Ginoulhiac of Grantbourne Chobham, Surrey, England wrote, “when there's a war raging such as there is now, there is always someone outstanding in whom one takes special interest, and in all their doings. When I first read about you and saw your picture I immediately cut it out and said that is one of the worthwhile people of the world. And all along you have proved it." 294

Upon learning of the presence of Patton in England, R.D. Brown offered his home as a place for Patton to come and escape from the trappings of the Army, as their house was less than ten miles from his headquarters. Brown invited Patton to "rest and relax at our fireside...." He and his wife "would be very happy indeed, and in fact would be highly honored, if you would regard our home as your own and use it as such, while you are in this district." 295 The swaggering American general indelibly impressed many individuals with whom he came into contact. "The villagers of Over Peover are thrilled and proud that 'their' American General and his army have in so short a time changed the whole face of the war by spectacular and resounding victories, and are more than ever proud of the Flag you presented to their Church as a souvenir of your stay - now at last exhibited for all to see." 296

Many British civilians remembered Patton from personal encounters. And Patton seemed never to forget a person who did things for him while in the United Kingdom.

\footnotetext{
${ }^{293}$ Letter, Grahane A. Patton to General George S. Patton, ibid. (August 15, 1943).

${ }^{294}$ Letter, E.F. Ginoulhiac to Patton, ibid. (August 27, 1943).

${ }^{295}$ Letter, R.D. Brown to Patton, ibid. (February 1, 1944).

${ }^{296}$ Letter, Reverand G. Cyril Green to Patton, ibid. (August 16, 1944). Over Peover, or Peover Hall, was the name of the estate near Knutsford, England where Patton kept his Third Army headquarters prior to landing on mainland Europe in July 1944. The flag Patton presented to the chapel remains for public viewing to this day along with a small plaque commemorating his time there.
} 
For example, the tailor from whom Patton purchased riding breeches in the early years of his military career wrote Patton during the war inquiring if he were the same man "for whom we made breeches, etc. for many years at Fort Myer, VA. We are extremely proud to read of your exploits in this tremendous war. We have been cutting from papers from time to time from England, Scotland, and also local Belfast papers." Even though Savage did not want a reply "for we know your hands will be pretty full," Patton took the time to write back. ${ }^{297}$ Patton so enamored some individuals that they desired to honor him in peculiar ways. Claire Brown of Knutsford, England, who was familiar with Patton's staff from her time working around them at Peover Hall, the pre-D-Day headquarters of Third Army, wrote to Patton on his birthday asking him to be the godfather of Sarah, her second child. ${ }^{298}$

Englishmen were not the only Europeans who thought highly of Patton. He was particularly apt to remember those whom he met decades previously, such as one Frenchman who apparently fled his native country and was living in Los Angeles. He and Patton met during the First World War and one of his daughters wanted him to run for president while his youngest daughter wanted to be either Patton's mother or wife. The father wished that he had been able to have "been ahead of you in France to tell my countrymen about you and your coming but I know that they are giving you and your men a warm welcome...."299

Like their American counterparts, French children also sent to "Old Blood and Guts" letters full of thanks and well wishes. A 15-year-old Parisian girl mailed Patton a

\footnotetext{
${ }^{297}$ Letter, Patton to Stricker, ibid. (September 1, 1944); J.C. Savage to Patton, ibid. (August 16, 1944).

${ }^{298}$ Letter, Claire Brown to Patton, ibid. (November 11, 1944).

${ }^{299}$ Letter, Charles Chomette to Patton, ibid. (August 13, 1944).
} 
beautifully self-illustrated card with a peace dove, Statue of Liberty, and the French and American flags as a "modest token of my gratitude" as Patton's troops were "completing the liberation of France and carrying the war into enemy territory." ${ }^{300}$ Another young girl from Lorraine who followed "with enthusiasm your prodigious and victorious offensive" through France sent "her warmest felicitations." Her brother was a prisoner in Leipzig, and she hoped for his liberation by Patton as well. ${ }^{301}$

A man of Patton's fame and intrigue could not go without having several lady admirers and on at least one occasion a certain self-deprecating woman solicited Patton. Miss Mary Pope, who ensured that she stressed 'miss,' did not have "a best beau in the service" and so made Patton her "pin-up General." She went on to say, "You may be somewhat surprised to find a female interested in you...but somehow you have been my favorite fighting man since I first read about you in this war" and she believed she had "darn good reasons for idolizing him." She included a photograph of herself, and admitted she was "no movie star, nor a celebrity, merely a plain Jane type" and if the "photo repulses you, kindly give it to anyone you feel might deserve severe punishment." She admonished the censors whom she feared would not get her letter to Patton as it may not be in good taste, but she was sure that "Lt. Generals appreciate fan mail...." If the censors failed to deliver her message or ran into trouble doing so, she would "gladly bring [them] cigarettes and soup while serving [their] time." ${ }^{302}$

Another young woman wrote Patton while recuperating from a major surgery and explained her anesthetic dream in which she crossed the Rhine River with Patton. This

\footnotetext{
300 Thank You Card, Yvette Charpertier to Patton, ibid. (January 18, 1945).

${ }^{301}$ Letter, Andree Blacfriar to Patton, ibid. (April 1, 1945).

${ }^{302}$ Letter, Mary Pope to Patton, ibid. (August 1944).
} 
girl, a great admirer of Patton's, also kept a detailed scrapbook of him but thought more of him as a father figure. "I hope you don't think me too forward for writing you. But you remind me a lot of my Dad. He was something like you." Like Patton, her father was strict, but "that's why I think so much of you, you and he are right, in what you think should be done. I know if he were alive today you would be a man he would think a lot of." Since she had no father, she asked to adopt Patton "as my Lt. General, but of course I think you should be a five star General, and I don't care who knows it."’303

The George S. Patton Papers held by the Library of Congress contains hundreds more letters, cards, and notes such as these. What is remarkable about Patton's fan mail collection is that he personally answered nearly every letter written to him until May 1945 when the fan mail really began to flow in, at which point Patton dictated his reply letters to his aide-de-camp. Upon review of the collection, it appears that Codman's calculations were correct: the overwhelming majority of correspondence Patton received throughout World War II were positive messages of encouragement and support. It is also important to note that Patton kept each letter, even those with a more negative bent, so it is unlikely that he trashed all the admonishing notes. Admirers sent drawings, sketches, poems, mementos, and trinkets along with their messages, and many were from countries other than the United States, attesting to the international appeal of the media darling. When someone asked for an autograph, picture, or keepsake from Patton, they typically received it. The preponderance of evidence, illustrated in this chapter with a few examples, demonstrates just how pervasive the Patton mythology and legend was during his lifetime and how successful newspapermen were, for their part, in driving a

${ }^{303}$ Letter, Mary Eva Honn to Patton, ibid. (April 17, 1945). 
narrative about Patton that increased his popularity with the public he served. It is difficult to argue that Patton was not one of, if not the most, popular soldiers in World War II. He truly became a household name.

It is true that Patton "prompted intense devotion as well as instant dislike." While the majority of his men, as well as the correspondents who worked with him throughout the war, would follow him to the ends of the world, some "judged him hardly representative of the best in America," calling him the "Huey Long of the armed forces, a swaggering, boastful blowhard, and thought it was tragic that his vulgarity and exhibitionism robbed his undoubted military genius of luster." But those detractors were people who did not work closely with him, who did not understand him at all, and could not appreciate him for who and what he really was. ${ }^{304}$ And they were definitely in the minority. What is clear is that during World War II, Patton's soldiers and former soldiers, headquarters staff, and the public at large had great admiration for the colorful war hero. And it was these people who helped form the collective memory in its earliest stages.

\footnotetext{
${ }^{304}$ Patton and Blumenson, 5.
} 


\section{CHAPTER IV}

\section{A COLLECTIVE MEMORY}

It is foolish and wrong to mourn the men who died. Rather we should thank God that such men lived. General George S. Patton, Jr.

On December 9, 1945, General Patton and his Chief of Staff, Brigadier General Hap Gay, left Bad Nauheim, the location of the $15^{\text {th }}$ Army headquarters, in a model 1938 Cadillac Series 75 limousine driven by Private Horace Woodring, Patton's personal driver. Following the staff car was a jeep driven by Sergeant Joe Spruce that carried the generals' shotguns and hunting dog. Patton decided that morning to take Gay pheasant hunting at a location he used prior, a trip that took the party along the Kassel-FrankfortMannheim autobahn. Along the way, the entourage detoured near Bad Homburg to the ruins of an ancient Roman outpost, indulging Patton's passion for visiting historic sites. By 11:30 that same morning the hunting party was on National Route 38, but became further delayed in the northern outskirts of Mannheim after the site-seeing detour due to two stops to solve vehicle problems and a military checkpoint. Riding up front in order to dry his wet boots under the dashboard vents until they reached the checkpoint, Patton later transferred to the back seat with Gay to make room for the dog, which took Patton's place in the front seat near the heater vent so it would not freeze to death in the jeep.

After stopping at a railroad crossing in Kafertal (a northern Mannheim suburb) to let a train pass, Woodring accelerated the Cadillac to around thirty miles per hour and the jeep driven by Spruce passed Patton's staff car to lead the way to the hunting fields. 
Coming from the opposite direction was a "deuce-and-a-half," a two-and-a-half ton Army truck, driven by Sergeant Robert Thompson. Thompson made a sudden left turn without signaling into a quartermaster depot and cut off the direction of travel for the Cadillac. Woodring was only able to slam on the brakes and veer to the left before colliding into the truck at a ninety-degree angle, smashing the Cadillac's front right fender, radiator, and grill.

For Gay, Woodring, and the dog, the crash merely caused minor scratches and bruises. Patton was far less fortunate, however. Thrown forward from his seat, Patton's head struck either the clock on the divider that separated the front and back seats or the light on the car's ceiling. A Y-shaped laceration on his forehead exposed Patton's skull and he bled profusely. He knew immediately that his injuries were serious. After enquiring if the other two men were okay, Patton asked Gay to work his fingers for him but felt nothing. Patton suspected correctly that he was paralyzed.

First on the scene was Lieutenant Peter Babalas, the same officer who later conducted the investigation of the accident. Babalas summoned the help of some nearby medical personnel and called for an ambulance, which arrived fifteen minutes later. Due to the seriousness of Patton's injuries, the ambulance bypassed the nearest military hospital in Mannheim and took him directly to the $130^{\text {th }}$ U.S. Army Station hospital in Heidelberg, which, although twenty-five miles away, was better equipped to deal with injuries such as this one.

The official prognosis from the swarm of doctors, neurosurgeons, attending physicians, and nurses was bleak. Patton's neck was broken and dislocated and he was paralyzed from the neck down, although he sporadically showed signs of improvement. 
Even though medical personnel gave individuals like General Keyes, one of Patton's best friends and commander of the area encompassing Heidelberg, a false sense of hope, Patton's time was limited.

Hundreds of letters and Christmas cards with get-well wishes flooded the military mail system, attesting to the incredibly positive public sentiment Patton once again enjoyed after the car accident. Mrs. M. J. Morse, "an old lady who has followed you through all your battles and admired you for the Red Blood that is in you" let Patton know through a message penned in a Christmas card that she prayed for a speedy recovery and that "God will bless you and spare you to your family."305 A multitude of other people who were admirers of Patton and who followed his exploits the entirety of the war were distraught by the news of Patton's injuries. For example, Miss Bessie Lee Porter of Louisville, Kentucky sent her message of prayers to one of "the greatest heroes America every knew, yes, the world ever knew!’306

Often, dozens of people signed a single card that made its way to Patton's bedside. Individual citizens, young and old, sent telegrams and Christmas cards that expressed not only their holiday wishes but their desires to see Patton speedily recover from his injuries. Others sent get well cards. Many recounted Patton's successes and heaped praise on him along with other sentiments. They offered their condolences and prayers to Patton, Beatrice, and the Patton family. Beatrice read the letters to Patton, a fact revealed to readers stateside, which encouraged people to write many more. Some wrote directly to Beatrice. Every message offered greetings and solace from a distraught nation.

\footnotetext{
${ }^{305}$ Letter, Mrs. M. J. Morse to Patton, in The George S. Patton Papers (Library of Congress, 1945).

${ }^{306}$ Letter, Bessie Lee Porter to Patton, ibid. (December 16, 1945).
} 
Americans followed daily reports on his condition in the papers. A political cartoon titled "Keeping an eye on the bulletin board" in the Indianapolis News portrayed Uncle Sam as "All America” holding a Christmas list in one hand, shouldering a stack of papers labeled as "our everyday problems and worries." He stared at a "Bulletin on the Condition of General Patton.” It was the only thing on the board legible and covered all other messages. Some believed the false sense of hope offered by misinformed journalists about a recovery that never materialized or by seeing optimistic political cartoons like one from the New York Journal that depicted the grim reaper being thrown out of Patton's hospital room. ${ }^{307}$

Messages came by the hundreds from all over the country, from far-flung places in North Dakota, Louisiana, California, and New York. Some contained religious medallions and tokens. Other admirers sent Patton sweet treats. Many were the parents and siblings of soldiers who fought under Patton and felt he was the greatest general in the war. Children also sent messages and drew pictures included in the letters to cheer up Patton, who cherished these messages above all others, such as the one written by Larry Kip Sleeth of North Liberty, Indiana who was "pulling for you. We know some soldiers from Trivoli, Illinois who were in your army, were proud of them, you too... You just have to get OK." At the bottom of the note one of Patton's aides scribbled, "Keep this." 308

307 "Untitled," New York Journal December 11, 1945. See political cartoons "Untitled," Indianapolis News December 1945; "Untitled," New York Journal December 1945. In The George S. Patton Papers, Library of Congress, Get Well Box Folders 1-7.

${ }^{308}$ Letter, Larry Kip Sleeth to Patton, in The George S. Patton Papers (Library of Congress, December 1945). 
Citizens, politicians, and military personnel of other countries sent messages of hope and encouragement as well. Mexicans, Frenchmen, Englishmen, and even Germans wrote of their hope for a full recovery. The mayors of Epernay and Rennes, France, two cities that made Patton an honorary citizen, expressed their best wishes. ${ }^{309}$ A French general wrote, "I sincerely hope that you will soon be well again. Every Frenchmen who will never forget what you have done for our liberation wishes you a very prompt recovery." ${ }^{\not 10}$ Some were from prominent officials such as Charles de Gaulle. Others were notable for their status as a former enemy, such as one former member of Rommel's Africa Corps. ${ }^{311}$

Although sometimes described as an anti-Semite and racist by revisionists, Patton received positive notes from the very populations who, if the allegations were true, may have rejoiced at Patton's misfortune. Instead, Jewish war veteran groups and their auxiliaries for ladies expressed their best wishes. A "British Jewess" who owned property in Bad Neumen, Germany, where Patton's Fifteenth Army Headquarters was located, offered her home for his use. A public call for prayer offerings at the Rabbi Soloman Metz of Ades Israel Congregation allowed concerned citizens to meet there and appeal to a higher power for Patton's health. ${ }^{312}$ A telegraph from Ira Lewis, president of the Pennsylvania based Pittsburgh Courier "feels that it expressed the hope and prayers of every Negro GI who served in the war and 15,000,000 Negroes throughout the nation

\footnotetext{
${ }^{309}$ Letter, Mayor of Rennes to Patton, ibid. (December 20, 1945); Mayor of Epernay to Patton, ibid.

${ }^{310}$ Letter, General Koenig to Patton, ibid. (December 1945).

${ }^{311}$ Letter, Alfred-Carl Gaedertz to Patton, ibid. (Wiesbaden, Germany).

${ }^{312}$ See Letter, Mrs. Margeurite Therels to Patton and Newspaper Clippings, ibid. (November 30, 1945). Located in Get Well Box 37-39, Folders 1-7 in The George S. Patton Papers, Library of Congress.
} 
in wishing you our heartfelt desire for complete recovery. America and the world need men who practice the democracy they preach."”313

Former staff officers from Third Army and subordinate commanders, such as Generals Manton Eddy, I.D. White (the commandant of the U.S. Cavalry School and, ironically, the general who used Patton's Cadillac after its restoration during his time as commander of the U.S. Constabulary), and other notable officers like Jimmy Doolittle sent their sincerest sympathies as well. Others were notes from veterans, sometimes private soldiers, "to one man we worship." 314 In a touching story, a woman wrote of her encounter with a wounded soldier who lost a leg, but who insisted

Don't feel sorry for me now - don't feel sorry for me ever. I was with Patton's Army. I can't run, nor jump, nor dance, nor swim, nor play ball, but I was with Patton's Army. I was with him when he straightened out the Belgian Bulge. I was with Patton's Army when he swam across the river in the midst of cakes of ice, and swimming back said 'come on boys we can make it' - don't you know we would have followed him to hell? When I die I want nothing on my monument except 'he was with Patton's Army.'315

Miss Wheeler was not alone in sending reminders to Patton that he held the deep and profound admiration and respect of his soldiers on the eve of Christmas while he lie in what was to be his death bed.

In times of crises, Americans pull together in unity and evidently there were many who viewed Patton's injury as such an event, as evidenced by editorials in newspapers across the country, such as one titled "Pulling for Patton" in the December 11, 1945 issue of Times-Picayune of New Orleans, Louisiana. School groups offered their prayers. Adult church and prayer groups of friends formed and met to pray. People wrote about similar experiences and injuries they sustained and the positive outcomes of their

\footnotetext{
${ }^{313}$ Telegraph, Ira Lewis to Patton, in The George S. Patton Papers (Library of Congress, December 1945).

${ }^{314}$ Christmas Card, Roy G. Mill and Clyde E. Rhymer to Patton, in The George S. Patton Papers (Library of Congress, December 1945).

${ }^{315}$ Letter, Miss Annie Wheeler to Patton, ibid. (December 12, 1945).
} 
treatment and how they pulled through, offering Patton hope. A physical therapist even offered his services to Patton for free. ${ }^{316}$

These messages let Patton know he was loved and adored by the public. Patton's "unique and heart-warming dash" won for him the general affection not merely of his troops but his countrymen back in the states. His indiscreet remarks "did not detract from his attractiveness...while he knew it or not, he has endeared himself to his country, and his country wants earnestly to see him get well.."317 Knowing his place in history was secure, his destiny fulfilled, that there were no other wars for him left to fight, and that the best he could hope for was semi-invalidism, Patton was at peace with dying. He begged the question, "Why won't they just let me die?" to a nurse on December 20 as he wondered what all the fuss was about as medical personnel strained to keep him alive. ${ }^{318}$

As soon as Beatrice received word of the accident, she prepared to leave Boston to be by her husband's side. Flying along with Colonel Roy Glen Spurling of Louisville, Kentucky, the best neurosurgeon the Army had to offer, Beatrice arrived in Heidelberg on December 11. For twelve days Patton survived in the hospital. However, on December 21, 1945, minutes after his wife went across the street to eat dinner, Patton expired from a pulmonary embolism and congestive heart failure.

Today, many Americans do not know how Patton died, possibly because the movie Patton, from which most common knowledge about the man comes, ends before portraying the vehicle accident. The manner in which he died, however, and the public response to his death steered a narrative of the man from that time hence. If Patton died

\footnotetext{
316 "Pulling for Patton," Times-Picayune (December 11, 1945).

317 "Good Wishes for Patton," Unknown December 12, 1945. In The George S. Patton Papers, Library of Congress, Get Well Box 37-39, Folders 1-7.

${ }^{318}$ Ladislas Farago, The Last Days of Patton (New York: McGraw-Hill, 1981), 271.
} 
of old age, it is improbable he would have been publicly remembered similarly, given precedent, such as the case of General Douglas MacArthur whose popularity faded after his career ended and he grew to old age.

A public outpouring of condolences, mourning, and nostalgic reminiscences flooded news sources. During Patton's time in the hospital, many journalists left the Nuremburg trials in which Nazi war criminals were being tried and sentenced to cover Patton's accident and time in the hospital: several of them even tried to sneak into the recovery room disguised as hospital workers. Clearly, the Patton story held a unique grip on the public's imagination at a time when more serious happenstances occurred that held longer-lasting implications for the future of Europe and United States foreign relations.

Responses were exclusively positive. In a letter to medical colleagues after Patton's death, Major General Albert Kenner, the chief surgeon for Service Forces in the ETO, wrote, "The service lost its best field commander and I lost a damn good friend." Colonel J. B. Coates, Jr., a doctor in the medical section of the U.S. Third Army, lamented that he was "sorry we had to lose General Patton but, at best, had he pulled through he would have been paralyzed from the waist down, and he was too grand an old soldier for that sort of life."”19

Patton's body laid for public viewing on December 22, 1945 in the Villa Reiner, a stately home in Heidelberg on a hill overlooking the Neckar River near Seventh Army Headquarters. A seemingly endless procession of soldiers paid their last respects to a commander, whom in life they respected but in death moved further into legend and lore. General Joseph McNarney, General Eisenhower's successor as the ETO commander,

\footnotetext{
${ }^{319}$ Lande, 278.
} 
began receiving a flood of dispatches containing sympathy and condolences. British Field Marshall Viscount Alexander cabled such a message, describing himself as "an old comrade and admirer of George." General S. Kopanski, head of the Polish Military Mission stationed in London, described Patton as "One of the greatest army leaders in history; his memory will live forever.” Even Field Marshall Bernard Montgomery seemed to lay aside any animosity he had for his rival and signaled from his headquarters in Germany that Patton was "a great soldier and a warm-hearted friend." 320 Montgomery wasn't alone in temporarily relieving himself of old resentments: death, it seemed, cured all ill will. For those who owed Patton a great deal of gratitude, the gestures were genuine, such as the French National Assembly which sent a message of condolence to the President of the United States, lamenting the death of "one of the liberators of France." 321

Lieutenant General Lucian Truscott, the commander who took over Third Army from Patton upon his relief from that post, issued a general order to be read to every member of his command. The general order was more a memorialization effort on the part of Truscott who described Patton as an "inspiring leader" and that the members of Third Army "lost a great friend; the country a great citizen and soldier," but that "his name will be writ large in the annals of military history in the forefront of the unceasing fight for freedom and Democracy." 322 The War Department also issued General Order Number 121, signed by Eisenhower on December 22, 1945, that reminded the nation of Patton's crucial role in defeating the Axis powers with his "sound tactical knowledge,

\footnotetext{
${ }^{320}$ Farago, The Last Days of Patton, 281.

${ }^{321}$ Quoted from New York Times article, December 22, 1945 in D'Este, 799.

322 Brigadier General H.G. Maddox, "In Memoriam - General George S. Patton Jr," (US Army Eastern Military Disctrict December 22, 1945).
} 
skillful, farsighted judgment, and masterful generalship," and echoed the idea that Patton would be remembered in perpetuity. ${ }^{323}$

The next day, pallbearers, accompanied by an honor guard of troopers and scout cars from the $15^{\text {th }}$ Cavalry Regiment, a unit which a younger Patton once commanded, took Patton's body past throngs of onlookers to the Christ Church in Old Town, Heidelberg as young children raced after the procession. Thousands lined the streets and crowded the rooftops in the dismal December German weather to catch a glimpse of Patton's casket as it passed by in a flatbed Army halftrack. Two U.S. Army chaplains conducted a short Episcopalian funeral service and a consolidated army band comprised of members from several divisions played when the casket arrived and left the church. A chorus of soldiers sang during the service. After the funeral, the same procession took the casket from the church to the train station where it left for Luxembourg. During the trip and along the railroad tracks, a series of spontaneous and touching ceremonies from soldiers caused the train to stop. Despite the darkness, rain, and cold, honor guards and bands turned out to pay respects to Patton and render one last salute as French officers placed wreaths of flowers on the train. ${ }^{324}$

Patton was fittingly buried at Hamm, Luxembourg on Christmas Eve Day, 1945 in a U.S. military cemetery in which most of the fallen buried there died during Patton's most famous victory, the Battle of the Bulge. Escorted to the cemetery from the train station by French and U.S. cavalry troops, Patton was interred by a group of pallbearers led by his trusted aide and longtime confidant, Master Sergeant Meeks, as several

\footnotetext{
${ }^{323}$ Edward F. Witsell, "General Orders No. 121," ed. War Department (Washington, D.C. December 22, 1945).

${ }^{324}$ D'Este, 801-02.
} 
dignitaries watched. Amongst the group of those present, along with family and friends, were several important persons such as General McNarney, two princes from Luxembourg, diplomats and representatives from France, Great Britain, Belgium, the Netherlands, Italy, Yugoslavia, the Soviet Union, Czechoslovakia, and a spattering of general officers from each nation. ${ }^{325}$ French, Belgian, American, and Luxembourgian troops lined the route for over three miles. During the 25 -minute ceremony and over the cracking rifles of a 12-man firing squad, the drone of an aircraft was heard. In it was a grieving General Walton Walker, one of Patton's former corps commanders who flew at his own expense from Texas but was unable to land due to the poor weather. Instead, the plane flew circles overhead so Walker could be close to his idol one last time. ${ }^{326}$

Although there were no eulogies given at Patton's funeral service, several statements made by politicians, military officers, and newspapermen regarding Patton after his burial framed nostalgia, collective memory, and public memory in the aftermath of World War II. It seemed as though all Patton's flaws were forgiven in the outpouring of tributes. Perhaps the New York Times best captured how most Americans thought of the late war hero in an article that waxed poetic and appeared the day after his death.

Long before the war ended, Patton was a legend. Spectacular, swaggering, pistol-packing, deeply religious and violently profane, easily moved to anger because he was first of all a fighting man, easily moved to tears, because he was a strange combination of fire and ice. Hot in battle and ruthless too, he was icy in his inflexibility of purpose. He was no mere hell-for-leather tank commander but a profound and thoughtful military student.... He was not a man of peace. Perhaps he would have preferred to die at the height of his fame, when his men, whom he loved, were following him with devotion. His nation will accord his memory a full measure of that devotion. ${ }^{327}$

\footnotetext{
${ }^{325}$ Captain WIlliam A. McKaney, "Funeral Escort Order," (Luxembourg City December 23, 1945) in Patton Archives (The General George Patton Museum).

${ }^{326}$ D'Este, 803.

${ }^{327}$ Article quoted in ibid., 803-04.
} 
Perhaps if Patton died immediately after his fatal car accident or during it, his return to grace might not have been as lasting as the forgiveness Americans gave him while they had time to reflect on the meaning of his story as he lay dying in the hospital. The suspense and oscillation between hope and despair added to the drama. For most of his career Patton alternated between scapegoat and hero. In large part, however, the timing of his death determined the hero status accorded him. Had he died immediately, the upsurge of positive emotion may have dissipated. Instead, he lingered in the hospital fighting for his life, and sympathy for him swelled as people had time to take pause and reflect on his accomplishments and reconsider his importance to the war. Americans came to believe that Patton was poorly utilized during the conflict by his superiors and when he died there was sudden and sincere grief from all over the world. Along with it came characterizations of his greatness, as America's most gallant soldier, the greatest general America ever knew, or the greatest general of all time. For many he was essential to the nation, and so unique that there could never be another like him. ${ }^{328}$

In the aftermath of his untimely death, there were memorial services for Patton all over the world, including in his home town of San Gabriel, California in the Church of Our Savior; in St. John's Church in Beverly Farms, Massachusetts; in the Cathedral Church of St. Peter and St. Paul at Mount Alban, Washington, D.C.; and the American Legion Tank Corps Post Number 19. Tributes did not immediately wane but lasted well after his death. Bills made their way to Congress to posthumously award him the Medal of Honor, promote him to five-star general, and erect a Patton National Monument. State legislatures also attempted measures to authorize memorials. Innumerable avenues,

${ }^{328}$ Patton and Blumenson, 836-37. 
public squares, and buildings were immediately named after him all over the world.

Poems were written, plaques placed, and statues erected. ${ }^{329}$ Clearly, Patton made his way into the collective conscious of the nation in a profound way.

Amongst the several memorial services held in the United States for those who could not make the trip overseas to attend the funeral, the largest took place on January 20, 1946 in the Washington Cathedral with twelve hundred attendees that included Henry Stimson, the former Secretary of War, and Eisenhower. Harry Semmes delivered a moving eulogy at the behest of Beatrice. A eulogy is a mode of public address designed not simply to memorialize an individual but to pass on cultural ethics by describing exemplary lives and deaths for others to emulate. It is a form of public memory influenced and developed by those who wish to predetermine and stabilize what are inherently fluid and transitory memories. Only rarely is the text preserved, but when it is, that record ensures that a new memory will last. Public memory is not dependent solely on stone or brick infrastructure. It can be done in oratory or in newsprint, reaching thousands of people. ${ }^{330}$ In Patton's case, it was preserved in the public record by several sources including Congress and General Eisenhower's general order, attesting to how strongly the public wanted to remember Patton and what narrative about him they wanted to preserve.

Patton strove to craft his public memory while he was still alive through his speeches, manner of dress, and crafted persona. Many leaders are concerned with their legacy and consequently are eager to secure their place in history, and there is little doubt that Patton was such a person. These individuals can be prone to conditioning memories

\footnotetext{
${ }^{329}$ Ibid., 838-39.

${ }^{330}$ Phillips, 9, 18.
} 
of themselves in things such as farewell addresses, like the one Patton gave to the Third Army staff when Eisenhower relieved him of that command. The construction of public memory requires additional rhetorical efforts that aim at mythologizing a person in the nation's collective memory. In the past, stakeholders used eulogies as political tools and had objectives embedded in the intersection between character and ideology and between the temporal and the mythic. As epideictic speech, funeral orations are performative, as they rely on noble acts and thoughts. Their ritual function is to create a sense of community and belonging among its participants, a key function of memory. Several essential aspects present in the rhetoric of memorializing include the marking of time, the dialectic between past and future, praising the dead, and lamenting their departure. Eulogies function beyond merely commemorating the deeds of the deceased. The emotional state of loss and the memories of the deceased can be harnessed to rhetorically instruct, educate, guide, and motivate: Aristotle understood the role of oration and its use as a means of telling the story of lived virtue. By valorizing heroes who are emblematic of a society's best qualities, encomia provide concrete guidance on how to live in harmony with noble ideas. In Patton's case, they served as a reminder of American exceptionalism: those who used epideictic speech to eulogize Patton advanced political objectives without necessarily resorting to overt partisan advocacy. ${ }^{331}$

Patton's reputation continued to grow. He became a myth, entering American folklore as a symbol of American greatness. He was half real, half god and an entire subculture arose around him, which perpetuated and spread fictional and exaggerated tales of his fabulous acts and incomparable courage. Patton "conformed to the most

${ }^{331}$ Ibid., 249-52. 
persistent traits of American national character, and identification with the man of the West." He was "a throwback to the cowboy folk hero" and personified the caricature of heroes in Western movies. ${ }^{332}$ Patton's granddaughter, Ruth Ellen Totten, summed up Patton's life and death in a lecture to the Topsfield Historical Society in 1974: "All his life he summoned unto himself a company of heroes, alive and dead, and in his death he lies among heroes to whom he was a hero. As a man thinketh, so is he." 333

Throughout World War II, newspaper columnists often managed to publish something damaging about Patton while censoring other potentially embarrassing stories. All of this changed on the day Patton died as they swept aside past controversy in a rush to depict Patton as a great general, perhaps the greatest of the war. The American people, by and large, sincerely mourned for him, and even those who previously called for his resignation after the slapping incidents, the Knutsford speech, and the denazification comments quickly changed their tune. During the immediate aftermath of hostilities in Europe, a popular image of Patton as a heroically simple and direct man of action appealed to those who wrote about him. As one historian noted, Patton "was not only removed from life and all the controversies life engenders, even his mortal remains...were buried in a place remote from the people of his country. Dead heroes make the best heroes, because, for them, time has stopped and there is no more of the messy business of life to interfere with the collective cultural projection that is myth. Upon his death, Patton was enshrined in the American mythic imagination." While

\footnotetext{
332 Patton and Blumenson, 840.

${ }^{333}$ Quoted in D'Este, 817.
} 
discussions of Patton still elicit controversy, the name of Patton never lost its grip on the public. $^{334}$

Praised and admonished in public discourse throughout the war, his funeral interned his body but not his memory, which immediately took a turn for the better. As one populist biographer wrote, Patton "was kind and friendly. He was a true Army man, a disciplinarian, though not too harsh or rigorous. He was held in high esteem and regard by all men whom he commanded, led or fought with...General Patton, to me, and to every enlisted man that served under his command, goes in my book as the greatest general of World War II." 335 This sentiment was by and large the most common one amongst those who wrote about Patton in the decades following World War II.

Stakeholders of the memory of Patton surfaced soon after his death, especially those with political motives. Hints of the Cold War were already recognizable in December 1945, and war hawks readily used Patton's advocacy for combating Russian aggression, leaning on his outspoken criticism of the Soviet Union and communism.

And yet, there was some pushback on the overwhelmingly positive legacy, particularly by those who had something to gain politically after the war, most notably Generals Eisenhower and Bradley. The jealousy of others towards Patton's collective memory was immediately visible: even as representatives from all the major commands plus delegations from Britain, France, Luxembourg, Belgium, Sweden, and the Soviet Union attended Patton's funeral service in Heidelberg, Eisenhower, Bradley, and Montgomery could not find time to attend. While forces were already moving to define

\footnotetext{
334 Alan Axelrod, Patton: A Biography (New York: Palgrave Macmillan, 2006), 174.

${ }^{335}$ Pearl, 138-39.
} 
Patton in history, some, like Bradley, felt relief that Patton was dead. ${ }^{336}$ But detractors failed to quell the trajectory of the legend. Patton was a hero to teenagers. Girls pinned his picture to their bedroom walls at home and at school, and boys viewed him as the embodiment of virility and other masculine virtues. He was, and remains, a hero to many Americans who admired his exploits. He was a heroic adversary even to the professional German officers who respected him as the general they most feared in battle. ${ }^{337}$

Historians and biographers also began to echo wartime journalists. Patton's preeminent biographer described him as a violent figure, one of America's greatest and most flamboyantly colorful generals. He was the man most responsible for the Allied victory and captured the imagination of people everywhere by his spirit and skill. "Hate him or admire him, it is impossible to ignore him," became a common theme. Patton's posturing and braggadocios swaggering, things that he did to enhance his public image, were efficacious in combat but the press portrayed him as a two-dimensional cartoon of a swashbuckling, sulfur-breathing, superman who lived up to the moniker "Old Blood and Guts." Living up to the legend, which was in full effect during his lifetime, forced him into an image antithetical to his actual disposition, a façade that became second nature, and one that often camouflaged his professional competence. It was an image that captivated the public, to be sure, and it was unlikely that the true nature of the man would have facilitated the same level of fame. The public became familiar with "the dominating figure with the high-pitched voice who used profane language unmatched anywhere in the army. This blood-and-guts figure was presented to the world with tongue in cheek, while he tried to conceal the military scholar, philosopher, and poet." It was difficult to

\footnotetext{
${ }^{336}$ Morningstar, 243.

${ }^{337}$ Patton and Blumenson, 4.
} 
know whether a certain statement was an act for effect or if it was genuine. Truly, he was individualistic and became a hero figure, but it came at the cost of obscuring reality. ${ }^{338}$

To understand the legend of General George S. Patton, one must first get close to understanding who he really was as an individual. He was a lonely man, in the sense that not many people truly knew and understood him. Patton lived rambunctiously in his selfmade world, with arbitrary conventions of his own design, groping desperately all the time to be revered. But he was seized by a strange inner panic and ran or shied away when he found understanding and love. For all his apparent physical and mental strength and his display of super-abundant energy, he was acutely afraid that he had some fatal weakness within himself - some brittleness or friability that could ruin his image, weaknesses of which he habitually attempted to rid and dissuade himself. ${ }^{339}$ Sadly, although he saw evidence of the public's adoration for his achievements, he never realized before he died how secure his place was in history. He never came to know that his destiny truly was fulfilled, the one thing for which he most stridently strove. Although he appeared impetuous, loud, inconsistent, expeditious, and opportunistic, in reality he was a highly unorthodox military thinker and progressive in his appreciation of the art and science of war, unwilling to accept pure dogma, and distrustful of established patterns. ${ }^{340}$ Patton considered war a sacred event and the warrior a sacred person and had a sense of religiosity about it. The Patton paradox, as it were, was "a baffling contrast between Patton's boisterous outward behavior and the sober rationale of his inner

\footnotetext{
${ }^{338}$ Ibid., 841-47.

${ }^{339}$ Farago, Patton: Ordeal and Triumph, 28.

${ }^{340}$ Ibid., 130.
} 
thoughts. He behaved as he did because he thought it would be a sign of weakness and surrender if he conceded defeat or showed his despondency." 341

Those who did know him intimately " 'knew the gentleness, the true courtesy, the almost puritanical uprightness and devotion to his religious convictions that were the real George Patton. Many of his friends had evidence of these traits. Underneath the seemingly rough and tough exterior was the thoughtful, sympathetic, almost boyish man.",342 But even this explanation was not enough. The real Patton morphed out of a childhood of hero worship that fed a belief in his personal destiny to achieve greatness, a lifetime dedication to be a learned and effective combat leader, an overcompensation for the fear he might develop the weakness of cowardice, and an insatiable drive to succeed. He was a walking paradox. Religious and profane, sensitive and aloof, compassionate and ruthless, cerebral and audacious, thoughtful and mercurial, aristocratic and relatable, Patton was one of, if not the, last great romantic warrior poets and one of the most widely misunderstood famous figures in U.S. history.

As if the real man did not make good enough a story in its own right, the Patton legend grew to disparate proportions. Patton wanted the recognition and honors that he believed he deserved. He wanted applause and adulation, the awards and decorations he was due. Most of all, he wanted the adoration of the public and, more importantly, of his soldiers and fellow officers. And he received all of it, although he never knew to what extent. Patton's great moments, the landings at Casablanca, the aftermath of Kasserine Pass in Tunisia, the invasion of Sicily and the capture of Palermo and Messina, the breakthrough after D-Day, his relentless pursuit of the German army, and the brilliant

\footnotetext{
${ }^{341}$ Ibid., 639.

${ }^{342}$ Quoted from a letter from Mrs. Harry Flint to Beatrice Patton in Semmes.
} 
relief of Bastogne and the salvaging of the Allied front during the Battle of the Bulge would not have been possible without the force of Patton the man and his inner being. This is the part of the Patton legend grounded in truth. ${ }^{343}$

It is a rarity for an individual to achieve legendary status while still alive, but Patton was one such person. And as demonstrated, that legend grew after his death. ${ }^{344}$ The Patton legend rests solidly upon his achievements in organizing, training, commanding, and leading into battle the first American tank force during World War I and upon his exploits during World War II. Widely recognized in military circles as one of the pioneers of twentieth-century mobile warfare and combined-arms actions, Patton's triumphs during World War II are solidly etched in the history of the United States Army, a legend of a conquering hero and the greatest combat general of modern times. Since World War II, his name became synonymous with fast, armored warfare and he is deservedly known as the master of American blitzkrieg. ${ }^{345}$

Many of Patton's contemporaries learned of his alleged greatness, as projected by journalists and biographers, through comparisons to other wartime leaders they were familiar with, such as fellow cavalry commanders Generals Nathan Bedford Forrest, Jeb Stuart, and George Custer. He was advertised to be a soul lost in his own time, the last of the romantic warriors, and the final nineteenth-century heroic figure in military history. In the coming of the nuclear age, the Cold War, Vietnam, and global terrorism, Patton was and is seen by many to be the "last heroic gasp in the proud myth of American

\footnotetext{
343 Patton and Blumenson, 856-59.

344 Lande, 280.

345 John Nelson Rickard, Patton at Bay: The Lorraine Campaign, September to December, 1944 (Westport, Connecticut: Praeger, 1999), xi-xvi.
} 
invincibility. ${ }^{״ 346}$ Clearly, General Patton earned a place in the pantheon of authentic American heroes. Arguably, as one preeminent Patton biographer asserted, during the expanse of U.S. history there has never been (and may never again be) another American quite like the George S. Patton, Jr. ${ }^{347}$

Few military figures in American history captured the public imagination more relentlessly than George S. Patton, Jr. and fewer still solidified themselves in public, much less collective, memory to the same extent. For generations after his exploits in World War II, his name still evokes the dash and bravado of a cavalry charge amongst those who are at least vaguely familiar with his story. Patton was certainly the one most feared by the Germans, who paid him the greatest compliment before Normandy of massing defenses against a nonexistent Army Group Patton and dedicated an entire spy network to figuring out his movements during Operation Fortitude. President Franklin D. Roosevelt assessed him as "our greatest fighting general" and the New York Times declared, "History has reached out and embraced General George Patton. His place is secure." Patton's legend certainly "transcends his military conquests" and is "complex and contradictory, larger than life and yet all too human...." He was a warlord fighting in the name of democracy who was unrepentantly aristocratic and had an uncommon devotion to the common soldier, two of which he slapped in the face. "He exuded confidence and relentless certitude" but in reality he was insecure, well read, fluent in French, and simultaneously crass, crude, and often foolish. He was a mystic and a devout Episcopalian. He delighted in slaughtering Germans but was reluctant to adhere to Eisenhower's denazification program. He was often a pain to his superiors who knew the

\footnotetext{
${ }^{346}$ Quoted from S.K. Oberbeck, "Total Warrior," Newsweek, October 7, 1974, p. 98 in Linenthal, 31-32.

${ }^{347}$ D'Este, 2, 5.
} 
war effort could not do without him so kept him in the fight. His men revered him, one saying, "here was a man for whom you would go to hell and back."348

To put it mildly, Patton was an authentic character, a successful and flamboyant military commander whose entire life was spent in preparation for a fleeting opportunity to become one of the greatest leaders in history. He delivered victories and led some of the greatest military campaigns in U.S. military history, the stories of which every American could read and hear about in newspapers and radio programs during World War II and multiple other mediums since. Opinions of him ranged from oversimplified admiration to outright condemnation, but what is indisputable is that George Smith Patton, Jr. was, in terms of collective memory, one of the unique Americans of this or any other century. Otherwise, the public memory would surely have waned. He represented the desires many Americans had for themselves: individuality and passion for life. ${ }^{349}$ Although Patton made mistakes on the battlefield, such as his decision to send a small task force rather than a combat command on the disastrous Hammelburg raid, and the meat-grinding battle of attrition at Metz, Patton mattered a great deal in the conduct of the war, contrary to what some of his detractors asserted. ${ }^{350}$ Take, for instance, the examples of Kasserine Pass and the Battle of the Bulge, in which Eisenhower turned to Patton to salvage two impossible situations. Aside from specific battles, on the strategic and operational levels the Allied effort struggled without Patton. Eisenhower failed to beat the Germans in Tunisia and suffered disaster at Kasserine without the best field commander he had. The Allies slogged into Tunis, only to win due to the Axis' failure to

\footnotetext{
348 Patton, Harkins, and Patton, xi-xiii.

${ }^{349}$ D'Este, 810-11.

${ }^{350}$ See Charles Whiting, Patton's Last Battle (New York: Jove Books, 1990). Whiting asserted that the legend faded quickly after the war and that he was not the folk hero American wanted or needed.
} 
bolster their depleted Afrika Korps. British General Bernard Montgomery got stuck in Sicily, saved only by the release valve actuated by Patton's race to Palermo and Medina. U.S. General Mark Clark faltered in Italy without the Patton imagination and audacity. General Bradley and Montgomery stalled in Normandy, only to move once Patton burst through German defenses and raced across France. Montgomery failed in Operation Market Garden even though consuming the majority of logistics at the expense of Patton's Third Army. Bradley could only wage bloody attrition warfare at Aachen and in the Hurtgen Forest and was caught catastrophically flat-footed by the German attack in the Bulge, only to be rescued by one of Patton's brilliant moves that remains to this day a part of U.S. Army lore. As General Albert Wedemeyer said upon hearing Eisenhower once criticizing Patton, “'Hell, get on to yourself, Ike; you didn’t make him, he made you. "’351

Patton became a larger-than-life figure, in popular conception, whose unique understanding of mechanized and combined arms warfare, his use of close air support, and his relentless drive to pursue the enemy made him one of the great commanders of World War II from a purely objective standpoint. It is difficult to deny that he played a large part of the overall Allied success, at least on the Western Front. Combined with his colorful brand, "swaggering self-confidence, insufferable brashness, a penchant for profanity, an explosive temperament, eccentricities, and a talent for exasperating his superiors - and you have a legend." ${ }^{352}$ It was a legend, as previously demonstrated, that news outlets and former subordinate soldiers and officers perpetuated and the public eagerly consumed.

\footnotetext{
351 Morningstar, 17.

${ }^{352}$ Lande, 7.
} 
Even though the picture of a "kindly father figure" emerged in the letters sent to Patton and his wife from soldiers and civilians during and immediately after the war, as well as some published biographical attempts to shed light on the real man, that was not what became the collective memory of him. These letters and books revealed an image of Patton that was a far cry from the "fire-eating, fire-spewing general" familiar to millions of people from the efforts of newsmen covering World War II. While he was alive and immediately after his death, the public pictured him sympathetically. But the papers reported that his personal character complimented his military image, that of a moody, temperamental, savagely profane commander who was easily moved to tears. War correspondents wrote about the peculiar instability in his personality and it made for good headlines. Yet perhaps Patton was, as one biographer noted, "courteous, urbane, and charming" and "carried within himself seeds of his later appearance, and these had blossomed by World War II and turned him into an exaggeration, a caricature of himself." The transformation into the image he wanted to portray was cultivated and self-willed and Patton had accomplices to allow him to be remembered the way he wanted to be, not the way he actually was. His was a conscious attempt to alter his image, stemming from a belief that men must be "compelled to conquer their natural instincts of self-preservation in order to perform deeds of valor in combat." By sheer force of will and against his natural instincts and inner disposition, Patton created himself in the image to which he aspired, the picture of virile masculinity that just so happened to coincide with his idea of a soldier, one that could inspire his troops to be the same. ${ }^{353}$

${ }^{353}$ Patton and Blumenson, 6-7. 
The way Patton wanted to be remembered, which belied his true self, in fact became the collective memory of General George S. Patton, Jr.

Before the dust could settle from combat operations in Europe after the German surrender, a fight over the legacy of the war began at the highest levels of the chain of command, stemming from the fear that blunders and missed opportunities would inevitably come to light. On May 10, 1945 General Eisenhower called a meeting with his four Army Commanders, Generals William Simpson, Courtney Hodges, Alexander Patch, and Patton. General Bradley was on leave and unable to attend. Why Eisenhower called the meeting without Bradley's presence is unclear, but the reasons for the confidential meeting were apparent to Patton. It was the beginning of an attempted cover up and did little to quell Patton's suspicion that Eisenhower was going to shape the legacy of the war in his favor. In his diary, Patton wrote that he

\begin{abstract}
Lunched with the Supreme Commander and four Army commanders and their air officers. After lunch General Eisenhower talked to us very confidentially on the necessity for solidarity in the event that any of us are called before a Congressional Committee. He outlined what he thought was the proper form of organization [for the occupation]. While none of us exactly agreed with it, it was not sufficiently contrary to our views to prevent our supporting it in general. He then made a speech, which had to me the symptoms of political aspirations, on cooperation with the British, Russians, and the Chinese, but particularly with the British. It is my opinion that this talking cooperation is for the purpose of covering up probable criticism of strategic blunders, which he unquestionably committed during the campaign. Whether or not these were his own or due to too much cooperation with the British, I don't know. I am inclined to think that he overcooperated. ${ }^{354}$
\end{abstract}

There was a distinct contradiction between Patton's wartime achievements and his critics' perceptions of him, which only proved to help make him a fixture in public imagination. Those contradictions caused many people to distrust his distractors - they saw what he did with their own eyes or read about his successes in the newspapers, so the naysayers lost credibility. Patch, Simpson, and Hodges were Patton's peers but these

${ }^{354}$ Ibid., 702. 
men are now generally forgotten except by military historians, yet numerous books and websites count Patton among a pantheon of great American field commanders that includes George Washington, William Tecumseh Sherman, Robert E. Lee, and Douglas MacArthur. Unlike his contemporary peers, Patton had a History Channel television series. One historian conducted a simple Google search that returned over 28 million hits on George S. Patton, Jr. compared to almost 18 million for Bradley. A similar search of the Amazon.com website showed hundreds more book titles on Patton as compared to his peers, none of which broke one hundred. This interest is all the more remarkable considering Patton's lesser position to Eisenhower and Bradley, "his extensive time spent idle, his early death, and the harsh postwar critiques."355 Although others grew to outrank him, none ever reached legendary status quite like Patton. His situational and adaptive leadership style gave him the ability to make soldiers follow him anywhere.

Within a few short years after the war, presses published a flurry of wartime memoirs of the generals, all of whom vied for a piece of positive public memory. A struggle for the war's legacy ensued. Arguably, Bradley, who had the most to lose from the momentum of Patton's legend, was the most critical of him. For Bradley, Patton was not his first choice for Army command. Bradley had reservations about how Patton would work under him due to his being older and more senior and his "impetuous habits." But Bradley soon relented that his were "uncharitable reservations" and admitted that few generals surpassed Patton as a field commander. However, Patton had one enemy he could not vanquish and that was his own tongue. ${ }^{356}$ Patton also reflected on his performance after the war and claimed that

\footnotetext{
355 Morningstar, 12-13.

${ }^{356}$ Omar Nelson Bradley and Herman Finkelstein, A Soldier's Story (New York: Holt, 1951), 231, 355.
} 
I can say this, that throughout the campaign in Europe I know of no error I made except that of failing to send a Combat Command to take Hammelburg. Otherwise, my operations were, to me, strictly satisfactory. In every case, practically throughout the campaign, I was under wraps from the Higher Command. This may have been a good thing, as perhaps I am too impetuous. However, I do not believe I was, and feel that had I been permitted to go all out, the war would have ended sooner and more lives would have been saved. Particularly I think this statement applies to the time when, in the early days of September, we were halted, owing to the desire, or necessity, on the part of General Eisenhower in backing Montgomery's move to the north. At that time there was no question of doubt but that we could have gone through and on across the Rhine within ten days. This would have saved many thousands of men. ${ }^{357}$

Bradley's religious piousness and modesty disallowed him to fully appreciate Patton's methods for relating to the troops. Bradley was not able to accustom himself to the vulgarity with which Patton berated offenders for seemingly minor infractions of discipline. Patton believed that profanity was the most effective medium of communication with his troops and his expletives lent immediacy to the situation. But while some chuckled over the famed cursing Patton employed with startling originality and creativity, the majority, it seemed to Bradley, were more often shocked and offended. "At times I felt that Patton, however successful he was as a corps commander, had not yet learned to command himself." 358 Bradley, who was unworthily caricatured as the "GI General" by the wartime correspondent Ernie Pyle, was preoccupied with Patton's personality, or rather stagecraft, and could not see past his own bias to see the effects, much less appreciate it for what it was. Patton's flamboyant public persona and Bradley's homespun image were diametrically opposed. The irony is that neither characterization fit the true personalities of these men.

For his part, Bradley admitted he was "startled by the suddenness of von Rundstedt's offensive" during the Battle of the Bulge. He had an infantryman's narrow view of why commanders attack (to gain terrain or destroy the enemy) and blamed Major

\footnotetext{
357 Patton, Harkins, and Patton, 331.
}

358 Bradley and Finkelstein, 52. 
General Troy Middleton, the division commander whose troops bore the brunt of the assault, for telling him he could defend through a delaying action. Bradley also blamed Eisenhower for approving Middleton's plan. In his memoirs, Bradley took no responsibility for the debacle, other than saying he "underrated the enemy's intentions," and justified his actions because he believed the German counteroffensive was a spoiling attack to relive pressure on the German lines from Patton's success south of where von Rundstedt's attack launched. The words Bradley chose in his war memoir are telling. Any success his army group had were his, but any failures were shared responsibilities or the fault of others. For example, he claimed "Although we had erred in evaluating the enemy's intentions, " [emphasis added] the estimation of their capabilities were correct. ${ }^{359}$

Much to the chagrin and dismay of Bradley, Patton won the admiration and affections of his troops and subordinate commanders in the ETO, but Bradley claimed the obverse was true in the Mediterranean Theater. "Canny as a showman though George was, he failed to grasp the psychology of the combat soldier. For a man who lives each day with death tagging him at the elbow lives in a world of dread and fear. He becomes reproachful of those who enjoy rear-echelon security and safety.... George irritated them by flaunting the pageantry of his command," which "did not awe the troops as perhaps Patton believed.... In Sicily Patton, the man, bore little resemblance to Patton, the legend." ${ }^{360}$ All evidence points to the contrary of what Bradley posited. Perhaps blinded by his bias, Bradley did not appreciate how well received Patton was and all of his critiques of Patton were strictly personal, not professional. As a religious man, Bradley despised Patton's crass language, extreme confidence, and flamboyant appearance.

${ }^{359}$ Ibid., 455, 59 .

${ }^{360}$ Ibid., $159-60$. 
Bradley's memoirs illuminated his vanity as he attacked Patton's fame, yet he was unable to deny the legend of Patton's greatness as a battlefield commander.

In the battle of the generals over the legacy of the war, Eisenhower also got into the act. Already reeling from the humiliation he felt after the publishing of My Three Years with Eisenhower in which his alleged former mistress and wartime lover depicted him rather unfavorably, Eisenhower sought ways to bolster his post-war image. Once, while Eisenhower passed the statue of Patton at the U.S. Military Academy with a reporter, the reporter remarked, "General Patton was quite a legend. Eisenhower replied, yes, mostly a legend!’361 In 1946, Eisenhower received a copy of a book titled Patton and His Third Army and wrote to the author that the book gave too much credit to Patton and should be revised to give most of the credit to Bradley instead. Patton, Eisenhower wrote, "was the most brilliant commander of an army in the open field that our or any other service produced. But his army was part of a whole organization and his operations part of a great campaign. Consequently in those instances where Patton obeyed orders, the story only hurts itself by assuming that Patton conceived, planned and directed operations in which he was in fact - the brilliant executor." ${ }^{362}$ In Eisenhower's attempt to bolster his pal's postwar image, he asserted that it was Bradley, not Patton, who facilitated the overall success. Over the next few decades, many historians disagreed with Eisenhower's favoritism of Bradley and attempted to recapture credit for Patton.

To add insult to injury, the $82 \mathrm{~d}$ Congress introduced two resolutions in 1951, both by representatives from Massachusetts, the location of Patton's final home named Green Meadows, to promote Patton posthumously to the rank of five-star general. This would

\footnotetext{
${ }^{361}$ Stanley P. Hirshson, General Patton: A Soldier's Life (New York: Harper Collins, 2002), 682, 85.

${ }^{362}$ Merle Miller, Ike the Soldier: As They Knew Him (New York: Putnam's Sons, 1987), 658.
} 
have placed him on equal standing with Eisenhower, Bradley, and Montgomery. Neither resolution passed and the Pentagon opposed both measures on the grounds that it was against policy ever to promote officers to that rank again. In 1950, Bradley became the last officer to wear five stars and as the ranking officer in the Department of Defense and first ever Chairman of the Joint Chiefs of Staff, he approved the policy. ${ }^{363}$

Patton's wartime diary played a role in the Republican primaries and convention of 1952 in which Eisenhower campaigned against Senator Robert Taft for the party's nomination. Eisenhower feared that Beatrice would allow the publication of parts of the diary that were damaging to his reputation, specifically the wartime blunders he committed and subsequently tried to cover up, downplay, or blame away. Rumors spread though the convention about the potential bombshell. Later, a conservative Chicago book publisher sought the diary as a political weapon against Eisenhower as he sought reelection after his first term. Ladislas Farago, a Patton biographer, lent a copy of the diary to William Randolph Hearst, who published excerpts that contained unfavorable material on Eisenhower. ${ }^{364}$

Of course, there were other naysayers who argued the Patton legend was overblown, although they were far outweighed by those who championed it. One such British author, Charles Whitting, asserted that over the years America turned to other matters and slowly forgot the Patton legend. Whether true or not, World War II receded into the past, overshadowed by new heroes. Those who remembered Patton were "portly, middle-aged gentlemen, who when they drunk too much drink at their local Legion post,

\footnotetext{
${ }^{363}$ See "House Joint Resolution 72," ed. U.S. House of Representatives (Washington, D.C. 1951); "House Resolution 174," ed. U.S. House of Representatives (Washington, D.C. 1951). Found in microfilm, Reel 2, George S. Patton Papers at the Library of Congress.

${ }^{364}$ Hirshson, 686-88.
} 
boasted they had 'fought with Patton." In Whitting's view, the legend faded into the history books and into "boring lectures at West Point, irrelevant stories in the nuclear age." Whitting misunderstood that authors and newspapermen created and perpetuated the legend in the 1940s and instead argued that reporters tried to resurrect the legend during the late 1950s to the early1970s until Ladislas Farago wrote the first serious book on the topic of Patton. This argument ignored the multitude of books published without end, not to mention the wartime correspondents' reports, beginning while Patton was still alive. According to Whitting, Ladislas Farago's book Ordeal and Triumph

revived the Patton legend once more, picking him out of obscurity into which all his fellow commanders had now disappeared.... The legend of Patton was rapidly becoming an 'American fodder.' But there was something else yet needed before that took place. After all, there were many millions of Americans who would never read Farago's book. The legend needed to be simplified and visualized so that Patton's life could be depicted to those who never opened a book. The time had come for Patton's wartime years - his ordeal and triumph - to be filmed. There was going to be a movie. ${ }^{365}$

It was the movie, Whitting argued, that "turned Patton the legend finally into Patton the folk hero.” Ernie Pyle, the famous World War II correspondent, dubbed Bradley the "GI General" at the general's insistence that the commentator must do something to bolster the retiring commander's public image. Later, Bradley married a 44-year-old screenwriter and started socializing with famous movie stars. ${ }^{366}$ Then, as an advisor to the movie Patton, Bradley ensured the movie perpetuated his plainspoken "GI General" moniker. Indeed, the movie did as much to solidify a skewed image of Bradley as it did for Patton.

Whitting, an embittered British fiction writer-turned populist historian asked, "But was - is - Patton the kind of folk hero America needs? He was an autocrat, and his

\footnotetext{
${ }^{365}$ Charles Whitting, Patton's Last Battle (Havertown, Pennsylvania: Casemate, 2002), 258, 65.
}

${ }^{366}$ Ibid., 267, 69. 
arrogance bordered on real contempt." Whitting was favorable to Montgomery and attempted to supplant the Patton legend by glorifying Montgomery and painting Patton as a warmonger who had little concern for the lives of his troops. Authors like him did not understand the depths of Patton and his immense popularity on both sides of the Atlantic and his book offered only a one-sided and narrow view of events. Whitting did not appreciate how Patton's death changed the narrative and did not grasp the trajectory the Patton legend took well before he died. "American folk hero?" he asked, "I think not. Patton was too complex, too eccentric, too peculiar to fit into that mold." ${ }^{367}$ Perhaps, but maybe that is what Americans wanted in their folk heroes.

Another explanation for why the legend persisted is the human attachment to ancient stories we tell to make sense of the world and transmit wisdom from person to person and generation to generation. Patton was viewed as a tragic hero, a noble warrior with a fundamental flaw and definitely had a peculiar relationship with the people of his country. He was esteemed as a protector and savior by many Americans and Europeans, a warrior knowledgeable in the mysteries of war. But he also became obsolete, at least in the military sense, beginning in the nuclear age when total wars with total victories seemed to pass, at least in perception. But his utility as a symbol endured. Immensely popular after the war, he came to represent romantic notions of American greatness. Remarkably, the persistence of that image lasted into the middle 1970s and beyond.

As detailed at length previously, the Patton legend was partly a self-created product. His consciously constructed and easily recognizable costume of polished helmet, riding breeches, and ivory-handled pistols was a means of motivating a

\footnotetext{
${ }^{367}$ Ibid., 269, 74.
} 
generation of young men reared on dime-store novels and comic books. Even the chief Patton detractor, General Omar Bradley, understood that everything Patton did was designed to create a dramatic effect. ${ }^{368}$ Staged outbursts of anger, scripted in the language of the troops, ironically made him relatable for the most part. Patton wrote that the "greatest gift a general can have is a bad temper (under control). A bad temper gives you a sort of divine wrath, and it is only by the use of a divine wrath that you can drive men beyond their physical ability in order to save their lives. ${ }^{" 369}$ Yet, over time, the carefully crafted image eclipsed the man. And, as demonstrated, the legend was first implanted in popular memory by news outlets in a deliberate act to generate hope and enthusiasm on the home front. The personal connections made by soldiers who served with him reinforced that narrative as they wrote home then later brought their attitudes back to the states, attitudes commonly shared by most civilians and sentiments that solidified due to the nature of Patton's death. Typically, soldiers tend to be "skeptical of commanders in general, and flashy commanders in particular, but they are loyal to leaders who accomplish their mission without putting undue hardship on their men. Soldiers were loyal to Patton." ${ }^{370}$ And Americans loved winners.

Since 1946, at least 300 published biographies and histories featured Patton as the prime subject. Almost all of them were sympathetic to Patton and his legend. Whether or not the legend is true is of little consequence to understanding public memory. Empirically and objectively speaking, taking this body of work as a whole along with the plethora of other mediums, it may be induced that Patton was the kind of folk hero

\footnotetext{
${ }^{368}$ Ayer, viii.

${ }^{369}$ Letter, George S. Patton to Walter Dillingham, in The George S. Patton Papers (Library of Congress, March 4, 1944).

${ }^{370}$ Morningstar, 8-10.
} 
Americans wanted and needed. Otherwise, the legend would not have endured the postWorld War II battle over legacies and would have faded into obscurity. What little the public knew of Patton's true character was only what he permitted them to know. Patton's legend was skewed by the façade he created and the public effortlessly accepted. That legend can be summarized thusly: General George S. Paton, Jr. was a swashbuckling, brash, profane, impetuous military officer who wore two ivory-handled revolvers and loved war so much he was nicknamed "Old Blood and Guts." image became part of the collective memory, the idea that he was America's greatest fighting commander during World War II. In the end his brand, self-invented personality, and victories overshadowed his moments of indiscretion that nearly destroyed him and distorted his place in history. That same legend unfortunately overshadowed the lasting legacy he left for the U.S. Army. The swarm of populist biographies that Americans read for generations helped make sure of it. But is Patton still the hero Americans want and need? This is a question for later chapters. What is known, however, is how several forces began to shape the narrative of General George S. Patton, Jr. after wartime journalists had their say.

${ }^{371}$ D'Este, 4. 


\section{CHAPTER V \\ SHAPING THE NARRATIVE}

The only way of learning the science of war is to read and reread the campaigns of the great captains. Napoleon, quoted by Patton in his reading notes.

Patton's brand, printed news source projections, and public sentiment stirred by his tragic death helped create the legend of Patton and all attest to the immense popularity of the war hero. Yet perhaps the most prolific driver of the Patton collective memory, at least until the movie Patton hit the box office, was the flurry of populist biographies and histories that fully entrenched the legend narrative in American consciousness. From 1946 until now, publishers released an average of two books each year with Patton as the main subject, the first being written while Patton was still alive. While other projections of public memory promulgated the legend narrative, wrapping him in time and place, these books, like the headlines he created during World War II, transcended the span of time and location. These early biographies about General George S. Patton, Jr., which included some compelling arguments about who he really was as a man but feebly attempted to dispel the Patton legend, set the stage for the hero narrative trajectory beyond the work newspapermen did during World War II. Aptly elucidating the Patton paradox (such as his bravado and simultaneous insecurity), most of the earliest works faintly described similar, although sometimes differing, interpretations of the legend. Those published within the first twenty years after Patton's death, before American 
involvement in Vietnam, influenced all those to come afterward and warrant deeper consideration.

William Bancroft Mellor began writing Patton: Fighting Man in 1945 during the time of the living legend, and provided readers with an obvious and predicable hero's tale, purposefully doing nothing to dim the luster on the Patton collective memory. Hastily written, Mellor's story of Patton ends before the fatal car accident on December 9, 1945, finishing instead at the point Patton lost command of the U.S. Third Army. The book concluded without the telling of that vital part of the story, giving evidence that the manuscript went to the publisher before Patton's death. Not intended to be a comprehensive history of the general, the book highlighted the career of World War II's most colorful American commander.

Beginning with an introduction that included one of Patton's infamous speeches, Mellor introduced the mechanism of rough soldiers' vernacular, warning that 'tough words from a softy never stiffened anybody's spine." With loose and flowery language, Mellor trumpeted his hero, seemingly willing readers to bask in the glory of "Old Blood and Guts." Mellor claimed that his "book is the result of an honest and painstaking search for the things which went into the making of that soldier" and explained that this work "is not intended to be an apology, nor as an encomium. Patton needs no apology." ${ }^{372}$

Mellor used first-hand accounts to build his narrative after speaking with Patton himself; Beatrice; his daughter, Ruth-Ellen Totten; his son, George Smith Patton, IV; and finally Patton's sister, Anne. Mellor's hyperbolic and populist account of the general's

${ }^{372}$ William Bancroft Mellor, Patton, Fighting Man (New York: G. P. Putnam's sons, 1946), 1, 6-7. 
life illuminated Patton's weaknesses but mostly glorified his strengths. Mellor was the first to capitalize on the Patton name and boldly commented that Patton "has become a legend in his own time" through his showmanship that he believed inspired confidence amongst his troops. Mellor borrowed a narrative from his journalistic peers, stating that

It is Patton the actor that the public sees - "Two-Gun" Patton of the ivory-handled pistols and the sinister little French hand sword; "Old Blood and Guts," riding across France at the head of his troops in a star-spangled jeep upholstered in red leather, and sporting multi-toned French horn and a machine gun mounted on the back seat; the blasphemous, hell-for-leather old cavalryman who drives his men like a Simon Legree, and who drives himself just a little bit harder; the hard-bitten martinet who slaps a solder for being scared - and who, a few minutes later, is weeping openly for his comrades who fell on the field of battle.

Patton's sense of theater was superb, and if some of his exhibitions of heroics were strongly interlaced with "corn," they still induced applause and laughter. ${ }^{373}$ Reinforcing the picture of Patton that emerged during the war, Mellor did little to state that the persona was in fact a façade that masked some of Patton's insecurities and gave his troops what he thought they wanted. Rather, he insinuated that Patton's showmanship was his true self that he simply amped up in public.

Mellor began his tale in earnest with Patton's childhood, using many nuanced insights that could only be gained through the most intimate oral history with the Patton family. By spelling out Patton's difficulties with school and college, his costume parties, and his doubts and fears, Mellor attempted to place a sense of humanity on Patton. However, any attempt to reconcile the man and the legend failed with his own touting of Patton's exploits. Despite Mellor's best attempt to argue that he was not an apologist, apologize he did, particularly when dealing with Patton's slapping incidences in Sicily in 1943. Giving the excuses that Patton "had been living on his nerves alone, stopping seldom for food or rest" and that he witnessed unspeakable horrors on the battlefield,

${ }^{373}$ Ibid., 16-18. 
Mellor claimed that Patton merely gesticulated wildly, accidentally striking the youth's head with his gloves. In fact, as Mellor explained, whether the blow "was intentional or an accident, even he probably does not know.” Furthermore, Mellor cited a Gallup poll that indicated seventy percent of respondents wanted Patton left in command of the U.S. Seventh Army. Surely Mellor believed his work to be on the side of popular opinion and reflected the general attitudes of Americans despite the few dissenting journalists' best efforts to the contrary. ${ }^{374}$

Patton, who was a hero and a legend before the end of World War II, did have an Achilles' heel, according to Mellor. Unable to tame his own tongue, the more Patton talked, "the deeper he got in hot water." ${ }^{375}$ Yet even Patton's missteps while the military governor of Bavaria could not undo his fame. Mellor, ending the book in melodrama with the scene of Patton's farewell speech to the Third Army, left readers with a sense of nostalgia and sadness for the general. That emptiness only exacerbated after Patton's tragic and unfulfilling death. The jacket cover exclaimed that fame spotlights a hero and people wanted a biography to tell them how he got that way. If that were so, Mellor gave readers what they wanted with a lavish amount of embellishment and a sheer aggrandizement of the Patton legend with this grandiloquent narrative of Patton's life and career.

The first compendium of military heroes after the war, Famous American Generals, described Patton as a twin, pearl-handled pistol toting commander who "swore with unbelievable ferocity, but he prayed with the same intensity" and "could deliver to officer or enlisted many an impartially and unmerciful tongue-lashing that would never

\footnotetext{
${ }^{374}$ Ibid., 191-92, 96.

${ }^{375}$ Ibid., 232.
} 
be forgotten," but could also become tearfully sentimental. This book introduced Patton to readers as "Hard as tempered steel, magnificent and unconquerable on the battlefield, he could - far from the sound of guns - be confused, inept and even childlike in his political and personal relationships." As many Americans already knew during the war, there was little indifference of attitude towards the man. ${ }^{376}$

For a public that purported to be leery of militarization and large standing armies during times of peace, it was difficult to accept George Patton for what he really was: a man of war specialized in his violent profession and a misfit during peacetime and in the realms of politics and civil affairs. But after his burial, impassioned tributes that mirrored the fan mail he received poured forth in print. Men and women who had never seen him in person became at once suffocated by grief. He was widely and finally accepted by his detractors, as this work asserted, who welcomed him without further reservation to the nation's pantheon of heroes. The public, who already elevated him onto a pedestal, perhaps even understood him to some degree. ${ }^{377}$

In the first book written by a former staff officer who served under Patton, Brenton G. Wallace, who served as Third Army Assistant Chief of Staff G-3, Liaison, wrote Patton and His Third Army, an account that did little to diminish the Patton legend and mystique. Also published in 1946 and dedicated to Patton and the men of the Third Army, Wallace wrote this book as an emotionally charged, populist, first-hand account that also placed Patton in a glorified status within a very general historical narrative of battlefield operations while providing some nuance through vignettes and life-as-a-

\footnotetext{
${ }^{376}$ Robert Hilles Shoemaker and Leonard Allen Paris, Famous American Generals (New York: Thomas Y. Crowell Company, 1946), 68-69.

${ }^{377}$ Ibid., 75-76.
} 
soldier stories. Wallace built his narrative beginning with the buildup in England prior to the invasion of Normandy and took readers across the English Channel, through the breakout from the Normandy hedgerows during Operation Cobra, the subsequent race across France, and to the Falaise Pocket. He then told the story of the Third Army being stopped due to logistical shortages, the fight for Metz and the Saar Valley, the Battle of the Bulge and the race into Germany, Czechoslovakia, and Austria. However, Wallace unsurprisingly stopped short of Patton's time as military governor of Bavaria and jumped forward to an emotional epitaph that detailed the inner workings of Patton as witnessed by a staff officer working in Patton's headquarters. Wallace conveniently left out the Sicily slapping incidents, which of course did not occur while Patton commanded the Third Army, but he inexcusably omitted the Knutsford incident, the ill-fated Hammelburg Raid, as well as Patton's gaffes to the media in Bavaria which ultimately cost him command of the Third Army. In fact, Wallace offered nothing in the way of criticism at all. Capitalizing on Patton's fame and the national mourning of his untimely death, Wallace crafted this populist book as an overt tribute to his hero. ${ }^{378}$

James Wellard was a war correspondent attached to the Third Army during World War II and his sweeping prose in The Man in a Helmet: The Life of General Patton (1947) (which was a republishing of the previous title Man Under Mars, 1946), illustrated the attention-grabbing style of writing employed by journalists that swept the Patton legend into the collective memory of many readers during the war. Wellard argued that Patton typified a phase of military history, what the author dubbed the "gunpowder wars," and asserted that Patton had a new label slapped on him with

${ }^{378}$ Brenton Greene Wallace, Patton and his Third Army (Washington, D.C.: Military Service Publishing Company, 1946). 
everything he did, with each new moniker representing the roller-coaster effect of the media on his actions. He also attempted to differentiate himself and his book from other newspaper writers and wartime articles, which were "haughty and hasty attempts to justify a successful general to a dubious public. ${ }^{\prime 379}$ Even so, his work was really a continuation of the same legend narrative and a recapitulation of wartime news coverage: there was hardly a "dubious public" that needed to be sold on "Old Blood and Guts."

Wellard posited that Patton became a symbol of World War II and all traditional and romantic wars, if there ever was such a thing. Patton's language, his message, and even his delivery method were part of the show. Yet there was a dichotomy in Patton's nature, which Wellard illustrated with Patton's poetry as evidence of his internal conflict. Furthermore, Patton's philosophies were incomprehensible to the public. War was beautiful and he loved it, albeit for reasons that not many others understood. Patton did not like the carnage; rather it was in the "profound quietness" of the soldiers, the gracefulness of their movements, the gravity and spirituality of the situation, and in the rare smiles that he found beauty. ${ }^{380}$

As with all those written during the decade after Patton's death, the book was dotted with embellishments and inaccuracies. Written before the luxury of archival material, Wellard relied on first-hand accounts and periodical narratives, which is perhaps why all of the earliest Patton biographies offered more of the same hero narratives written in the newspapers during the war. While Patton captured the public's imagination with his tank battles and his unique uniform designs, newspapers later told

\footnotetext{
379 James Howard Wellard, The Man in a Helmet: The Life of General Patton (London: Eyre \& Spottiswoode, 1947), ix.

${ }^{380}$ Ibid., 1-2, 14-15.
} 
stories that gave a soft impression of a father figure to his troops, an assertion that this author disputed. But, Patton was an astonishing figure in appearance and a "quiet man, even with well-controlled signs of nervousness." ${ }^{381}$

The book offered a much grittier account of the fighting than those in other books of its time and also offered a hypercritical account of the Sicilian campaign. True to Patton's contemporary detractors, Wellard emphasized the slapping incidences while downplaying the strategic value of Operation Husky. Yet, while he did give more weight to the slappings, he was surprisingly lenient on Patton, essentially explaining away the gaffes with a justification for Patton's bellicose behavior. Wellard intuitively pointed out the reciprocal, even symbiotic, relationship between the newspapers and colorful personalities that made readers want to read more - a reason why Patton received so much press. ${ }^{382}$ As the soldiers' "personal loyalty to Patton was astonishing, and even extended to a jealous regard for the man's personal fame," there can be little wonder why many civilians felt the same way. In Patton's own words, Americans love a winner. However, Wellard was wrong in his last calculation of the book. Patton did not disappear "from the front pages of the newspapers to the footnotes of the history books." 383 Patton's memory remained alive in the collective and public memories of Americans and Europeans, albeit to different degrees.

Colonel Robert S. Allen, a controversial figure in his own right, was the second staff officer to write about his former commander. ${ }^{384}$ His book Lucky Forward, written

\footnotetext{
${ }^{381}$ Ibid., 124.

382 Ibid., 120.

${ }^{383}$ Ibid., 236.

${ }^{384}$ Allen was wounded and captured in April 1945 and had an arm partially amputated in a German hospital before being liberated shortly thereafter. Before serving on Patton's staff in WWII, he served in France during WWI, was a syndicated columnist, and Bureau Chief for the Christian Science Monitor. During that period he was a paid informant for the KGB.
} 
as an operational history (of sorts) of the Third Army in the ETO during World War II, had clear overtones of a Patton admirer's attempt to keep the general in the foreground of public consciousness. However, even as a falsely exclaimed "true narrative," Allen's book did much to illustrate the ways in which the Third Army took on the persona of its dynamic leader.

Allen began his narrative in England prior to the June 6, 1944 invasion of Northern France, with a brief prelude regarding Patton's background and personality. Throughout the book, Allen explained to readers that Patton's behavior was for show, an attempt to make himself visible to his men. Throughout, Allen claimed SHAEF had a consorted aim to extinguish the Patton legend, a futile and unnecessary effort on their part as the creation of the legend had a specific purpose and design that served the overall strategy well. Allen correctly understood the media needed a star they could present to the American people and they found one in Patton. Yet, according to the author, it was SHAEF, not the German enemy, who presented the largest challenge to Third Army's success. While Allen asserted there was a shocking level of incompetence of headquarters staff above Third Army, he was not shy about claiming excellence among Patton's staff, of which Allen was a part. He gave an insider's look into the inner workings of an Army staff but it was clearly a partisan work that regaled readers with tales of glory while placing blame for the Third Army's shortcomings squarely upon higher headquarters. Meanwhile, as the tale unfolded, snippets of a picture of Patton emerged. ${ }^{385}$

${ }^{385}$ Allen. 
The Patton family finally got a say in the legend narrative with the publication of Patton's war memoirs, War As I Knew It, first released in 1947. While serving as the commander of the U.S. Fifteenth Army in late 1945, Patton wrote about his experience during World War II and a series of articles dealing with subjects closest to his heart; leadership, tactics, combat, and horsemanship, which became the final two chapters in the book. This memoir was easily one of the most important pieces of the Patton legacy for the Army. However, it was purged of nearly all of Patton's outrageous language by Patton's wife Beatrice and his former Deputy Chief of Staff, Paul D. Harkins. It became a best seller, but because it was also stripped of Patton's candid remarks regarding the blunders of his superiors and peers, the book was politically correct and only mildly controversial. Unfortunately, Patton never finished what his friend General Geoffrey Keyes called, "what could have been the greatest book to come out of World War II." However, it did serve Beatrice's aim of keeping the memory of her late husband alive. It remains in print today and is widely read by those curious about Patton. ${ }^{386}$

In another early populist biography written by a non-historian and non-veteran (Mellor was the first), Alden Hatch produced a short, easy-to-read book that covered mainly the World War II years of Patton's career. General in Spurs was intended for and marketed to teenage boys and young men. Without veiling his intent, the book jacket stated that Hatch "tells how one of America's great generals became a legend in his own lifetime." Patton, Hatch claimed, steered himself in one direction - "to be a great general." Ascribing meaning to the collective memory of Patton, Hatch described him as "the symbol of victory to Americans, everywhere, and of terror to the Nazis." Although

${ }^{386}$ D'Este, 779, 806, 18. 
the author had several glaring omissions (for example, there is no mention of Patton's performance as military governor of Bavaria), the worth of the book lie elsewhere, in the realm of memory. Hatch did raise some valid questions, such as Patton's utility as a great strategist or merely that of a suburb tactician and what matter of man he was: a "hardboiled brute or a warmhearted old curmudgeon?"”387 Hatch's work also revealed some untold - not retold - stories and details about Patton, probably as a result of his direct communication with Patton's wife and daughter, who both read the manuscript for accuracy. As evidence of the Patton legend trajectory after 1945, Hatch, like other authors, admitted the controversies that surrounded Patton during his life but also those that arose after his death. According to Hatch, it was these controversies, along with Patton's stellar combat record, that perpetuated the myths and legend of Patton, not the news projections.

Harry Semmes wrote Portrait of Patton, another volume that fits into the genre of early Patton biographies written by former staff officers. Semmes served as commander of A Company in Patton's tank battalion in World War I and also laid next to Patton in a field hospital after being wounded in the Battle of the Meuse-Argonne in 1918. Interestingly, Semmes recounted a tale of how he and Patton left the field hospital early to rejoin their unit during the battle and is perhaps one of the earliest, if not the first, written evidence of this story. Of course, the story is unverifiable. In fact, it is contradictory to archival evidence, and this book should be approached with heightened skepticism. Unfortunately, later biographers did not and recounted the story, blindly accepting Semmes' tale.

\footnotetext{
${ }^{387}$ Hatch, George Patton, General in Spurs, 175.
} 
Like others before him, Semmes claimed his book to be a "straight narrative" with "vivid, nostalgic anecdotes" and described Patton as a "flamboyant individualist who was feared by the men he battled, and idolized by the men he commanded." In it, Semmes traced the Patton story from childhood (although only touching lightly on this time of Patton's life - the book began in earnest with Patton's time at West Point) through his education, marriage, and early career, with the most time spent on World War II. Semmes wanted to "show what made Patton tick" in this intimate picture written by a friend. ${ }^{388}$

Like Patton, Semmes was an early proponent of tanks and spent parts of his book advocating for the Army's armor branch. Rather than simply projecting his own views on Patton, Semmes spoke to the admiration his soldiers had for Patton and how most loved serving under him. Semmes hinted towards the attitude followers had of the general and how they identified with their commander. In a feint of objectivity, Semmes called Patton moody, hot-tempered, and reacted sometimes like a spoiled child. However, he craftily stated these assertions in a way that seemed like a compliment rather than a critique. In an honest attempt to depict the human side of Patton, Semmes listed incidents that told a different side of the man, such as his chivalry (he once gave $\$ 800$ to an unmarried Red Cross girl he did not know who needed money to have a baby she conceived with a soldier), ended each chapter with a poem written by Patton, and incorporated letters to and from Beatrice and reflections from others who knew Patton.

It was Semmes who fed conspiracy theorists with the false assertion that the Cadillac Patton rode in during his fatal crash was driven away. The final pages consisted

\footnotetext{
${ }^{388}$ Semmes. See dustcover.
} 
of a chapter about the conclusion of the war and statements regarding Patton's views of the Soviet Union as "100 percent true, and very undiplomatic from the point of view of the leaders in political control at the time." 389 According to Semmes, Patton believed the Cold War was preventable if world leaders listened to him. Overall, Portrait of Patton added a great deal to understanding the origins of the Patton legend and the history of collective and public memories. While Semmes did not particularly uncover Patton the man himself, in the context of identity, memory, nostalgia, legend, and myth, the book was important for Patton historiography as evidenced in the preponderance of citations in the works of later biographers.

Patton and His Pistols (1957) was a quick history of Patton using the famous pistols as the catalyst for discussion. Although the book mostly detailed Patton's side arms, it built upon the legend and reinforced the image of Patton as an iconic war hero by utilizing recognizable objects, symbols which readers gravitated towards. ${ }^{390}$ The same year, Drive, by Patton's aide-de-camp Charles Codman, provided insights into what one of Patton's closest confidants thought of him. Codman's book was very generous towards Patton yet illuminated many of Patton's eccentricities and his unique personality by opening a window into Patton's inner circle of confidants. Written as a series of edited letters the author wrote to his wife during the war, Drive was mostly about the war experience of Codman but because Patton was such a large part of his everyday life there was much commentary regarding the general. ${ }^{391}$

\footnotetext{
${ }^{389}$ Ibid., 284.

390 Perry and Parke.

${ }^{391}$ Codman.
} 
Not all publications about Patton were positive. Phil Hirsch's Fighting Generals (1960) included a chapter titled "The Combat Snafu of 'Blood and Guts' Patton," that related one story from Patton's life, that of the doomed Hammelburg raid and Task Force Baum. Not really about Patton at all, this story is more about the men who went on the expedition and the sensational story of that failure while placing the blame squarely on Patton. ${ }^{392}$ However, the trajectory of the Patton legend was undisturbed: the following year publishers released Blood and Guts Patton by Jack Pearl (1961). Written in the format of a dime store novel, which cost $\$ 0.35$ when published, this dramatic book for boys was full of conjecture. Using scant sources such as other early populist biographies and newspaper articles, the book included dialogue that obviously never could have been captured to add color to the story presented. Inaccuracies sprinkled amongst truths made it difficult to separate the two and lent to the perpetuation of myths surrounding Patton. ${ }^{393}$ Another populist history from the early 1960s, Famous Military Leaders of World War II by the Editors of the Army Times (1962), forwarded parts of the Patton legend as well. Intended for the laity, this book contained a short eight-page overview of Patton. However, it did contain some valuable insights - by 1962 authors began seriously addressing the complexity of the Patton story and his many paradoxes. This book addressed the irony of Patton bashers who forgave all in the end due to his untimely death. However, its importance was that it marked the final populist account before the first serious attempt at Patton scholarship emerged. ${ }^{394}$

\footnotetext{
${ }^{392}$ Phil Hirsch, ed. Fighting Generals (New York: Pyramid Books, 1960).

${ }^{393}$ Pearl.

${ }^{394}$ Famous American Military Leaders of World War II, (New York: Dodd, Mead \& Co., 1962).
} 
In his critique of earlier works, Ladislas Farago charged in Patton: Ordeal and Triumph that the efforts of previous studies were written too soon after the war before most important documents chronicling the conflict surfaced from a mountain of classified documents and therefore could not possibly cover the depth and complexity of Patton. "Amateurs whose chief qualification was their friendship or kinship with the late General," according to Farago, wrote the earliest populist biographies. ${ }^{395}$ In other words, they were just too close to give an objective account or were stakeholders in the collective memory. And yet, although Farago was correct, afterwards there were many more like those that came before him.

Farago examined the Patton legend with a critical and scrutinizing eye. The early crusaders of the collective memory created a convoluted picture of Patton, one that was not easily undone. Meanwhile, Farago had an ability to keep readers engaged through his polished prose and presented an alternative, and more accurate, depiction of "Old Blood and Guts" Patton: a profoundly misunderstood individual whose energy fueled an entire army around which grew a legend that celebrated his excesses. Farago drew upon a wealth of documents, first-hand accounts, oral histories, after action reports, and personal papers, claiming over 400 bound volumes consulted during his 12-year journey from start to finish. Farago's work was astoundingly colorful and rich, and included a personal narrative that read more like an historical novel. This was only possible because Farago's in-depth research included accounts from those who knew Patton professionally and on a personal level. The Third Army's confidential secretary to the Commanding General, Joseph Rosevich, to whom Patton dictated general orders, combat narratives,

\footnotetext{
${ }^{395}$ Farago, Patton: Ordeal and Triumph, 848.
} 
reports to Eisenhower, as well as comments on men and events, was Farago's “source supreme" who detailed major events in the war with a colorful and vivid lens towards Patton, a description never before realized. ${ }^{396}$ Codman, along with German officers who opposed Patton, veterans of World War II who served under Patton, and other subordinate commanders' color commentary enriched the narrative.

Strangely enough, Farago completed the first definitive work without the use of Patton's personal papers, instead mostly relying upon writings from the interwar years published in the Cavalry Journal, Patton's essays, and his autobiography, War As I Knew It. However, the Patton Papers, published in 1972 and edited by Martin Blumenson nine years after Ordeal and Triumph made it to the bookshelves, were hardly missed by Farago who, by all accounts, remarkably pieced together the most complete Patton story up to that time. In a writing style uncharacteristic of an historian (probably due to his lack of formal training and partly due to the extensive use of first-hand narratives and oral histories), Farago detailed the life of Patton by starting out his narrative in Morocco during Operation Torch, the Allied invasion of North Africa. The most bothersome aspect of this work was the conspicuous absences of citations of any sort, save for the bibliography, rendering what could have been the definitive work on Patton nearly unusable for later historians.

Additionally, Farago did not make a concise argument, per se, until the closing pages. In his acknowledgments, Farago stated that his purpose was in part to draft a complete, fitting, and overdue portrait of Patton. Moreover, the image of the "great captain of war...who slapped an enlisted man, then redeemed himself by leading a

\footnotetext{
${ }^{396}$ Ibid., 849-50.
} 
dashing and dramatic campaign at the head of a competent and romantic army" was an oversimplification worthy of correction. Fargo stated that Patton was more complex than what collective memory held. Patton "was not so evil as the man seemed to be who had struck a nerve-racked soldier. And he was not quite as good as the legend." Rather, Patton did not fit any personality profile, but was "Split in the ego - a confusing and confused man who pendulated [sic] between bravado and humility, between feelings of inferiority and superiority, in a subcutaneous $[$ sic $]$ torment that wrought havoc within the inner stability he so desperately sought." ${ }^{397}$ Additionally, Farago attempted to illustrate how Patton, "who was regarded merely as a tactical genius" by most historians and contemporaries, "was equally talented as a planner with fascinating strategic flair and vision," as evidenced through the narrative of Patton's role in Operation Overlord, "a role in which even today, he is still not recognized." 398 As Farago explained, Generals Eisenhower and Bradley failed to see strategic developments and opportunity. These commanders' inflexibly forced them to fight the Overlord plan, not the enemy - they did not make adjustments during the fight based on evolving situations or take advantage of emergent opportunities, rather they stuck to the plan at all costs. Meanwhile, Eisenhower relegated Patton to a subservient role in attacking though Brittany but it was Patton who made a breakout possible through initiative and insight.

At times, Farago was speculative. For example, he asserted that Patton was not particularly political or diplomatic, yet he was able to form a consensus in Morocco, albeit a shaky one. Creating peace with Muslims, Jews, and Vichy French in a colonial society would be a mountain of a chore for whoever attempted it, yet Patton somehow

\footnotetext{
${ }^{397}$ Ibid., 848.

${ }^{398}$ Ibid., 430.
} 
succeeded. For a man with supposedly very little political or diplomatic talents or training, Patton faired decently in North Africa.

Farago spent far less time on the early years of Patton, which only garnered nine chapters of 128 pages. He devoted the remainder of his book to a mere four to five years of Patton's life. However, it was during these years, World War II, where the Patton legend evolved and naturally where Farago chose to focus. Book one, "The Ordeal," led up through the slapping incidences and book two, "The Triumph," was a recollection of Patton's major battlefield successes and the solidification of Patton's place in the pantheon of great generals. Perhaps Farago chose the book names poorly. Patton had quite a number of ordeals after Operation Husky to be sure and was triumphant on at least three occasions prior to the D-Day landings. However, the second half of the work recalled Patton's involvement as the commander of the mythical First US Army Group (FUSAG) during Operation Overlord to his sudden and anticlimactic demise.

As far as demonstrating the complexity of Patton's character and the unpredictability of his personality, Ordeal and Triumph hit the mark. Farago had an uncanny ability to explain the inner workings of Patton's mind along with many of his antagonists and protagonists. However, because follow-on studies were largely unable to use the book for references other than a general list of sources in the bibliography and because the author did not utilize Patton's papers other than a few journal articles and autobiography manuscript, Farago's work cannot be taken alone as the definitive biography of Patton.

It would be thirty more years until publishers released what could be considered a quality historical analysis of Patton, in academic parlance. Meanwhile, populists 
continued to churn out books that helped keep the Patton legend alive and forwarded the collective memory. For all their faults and flaws, the first publications about Patton drove a narrative that persists even today with little deviation or variation. The influence that early biographies had on the Patton collective memory, and therefore on other topics like military strategy, cannot be overstated. But neither can Farago's deviation from the norm. Although they dominated it, no longer would populist hero worshipers monopolize the narrative, at least in print.

Patton's legend and legacy partly stemmed from the fact that his story was presented in a number of biographies that inevitably suffered from a variety of handicaps. Farago was correct: amateurs wrote the majority of them too soon after the war before the declassification of key documents. The result was a picture of Patton on the fringe some exclaimed him to be the very symbol of America, a swashbuckling cowboy "Blood and Guts" caricature. As such, the Patton that later emerged from the cacophony of second-hand evidence became a complex and justly controversial figure, as he was in life. In the popular mind, he survived as a great battlefield commander, as the mercurial troublemaker who redeemed himself by leading a dramatic campaign at the head of an effective army, the man who gave Americans hope. This collective memory, as it were, was an oversimplification promulgated by the early biographers. The deed was done: the Patton legend was firmly entrenched in collective memory.

Beyond the populist machinations that publishers rushed into the hands of readers, taking advantage of public sentiment after Patton's death and the collective memory that was in the forefront of public consciousness, the overall historiography on Patton is, of course, part of memory projection, both public and collective. Unfortunately, few later 
accounts of Patton gave attention to how his story became increasingly distorted in the first place, failed to move beyond innuendos about the legend, and only a couple hinted at what Patton's story means for the organization he loved the most - the United States Army.

The number of publications that spanned from the release of Farago's work exhibited a trend that warrants note. In the 53 years since Farago's Ordeal and Triumph, there were only seven years that did not have at least one book publication about Patton. Most salient is the upward trend. In the 1970s, there were on average 1.4 books published about Patton each year. In the 1980s it rose to two. In the 1990s, the number was 2.2 , the early 2000 's there were 2.9 , and since 2010 there have been 3.6 books published on average each year. Of course, this may be due to several factors, not the least being that there are many more publishing companies along with the proliferation of self-publishing tools. However, what is clear is that public fascination for the late general did not wane - the numbers indicate that he continued to increase in popularity. Before 1966, there were only 18 Patton books published, or about 1.1 books per year. Since that year, at a minimum over 250 books on the topic found the hands of readers.

While the collection of published works on Patton certainly contribute to the collective memory and the upward trajectory of publications is notable, as a matter of comparison, the overall historiography on Patton is surprisingly sparse for such a notable figure. Once can only speculate why there are not more given Patton's popularity. There are around 300 published books and articles on the topic, no small amount, but the overwhelming majority are populist accounts. A handful of reputable sources 
overshadowed the rest. ${ }^{399}$ These more scholarly approaches provided lengthy and detailed accounts of the life and career of Patton. Others offered succinct surveys of Patton's story by highlighting the more poignant points in his career. Yet, in their descriptions, these authors, save for one, merely hinted at the collective and institutional memory of Patton even as they contributed to it. The literature addressing the meaning behind the memory of Patton is scant, and secondary sources fall into nine categories; first-hand accounts written by those close to him, "I fought with Patton" narratives by soldiers under his command, biographies, analytical histories, comparative biographies, populist biographies, conspiracy theory narratives, children books, and coffee table books.

Publications from former staff officers who served on Patton's primary staff comprise the bulk of first-hand accounts and span a considerable amount of time, the latest being published in 2019. ${ }^{400}$ Family members, including Patton's daughter, nephew, and two grandsons wrote several others in an attempt to exonerate their famous relative. ${ }^{401}$ Even Patton's autobiography was highly edited by his wife, who left out portions of the original manuscript that were critical of several of Patton's contemporaries. ${ }^{402}$ Related are several books written by former soldiers who served under Patton. These provided some anecdotal evidence of his popularity with the

\footnotetext{
${ }^{399}$ When compared to other famous military leaders, Patton historiography is sparse. For example, some estimates put the number of books about Napoleon at around 300,000. See "Books Written About Napoleon Bonaparte History Essay," https://www.ukessays.com/essays/history/books-written-aboutnapoleon-bonaparte-history-essay.php.

400 Jon Mikolashek and Paul T. Mikolashek, Blood, Guts, and Grease: George S. Patton in World War I (Lexington, Kentucky: University Press of Kentucky, 2019); Benjamin Runkle, Generals in the Making: How Marshall, Eisenhower, Patton, and their Peers Became the Commanders Who Won World War II (Guilford, Connecticut: Stackpole Books, 2019).

${ }^{401}$ Ruth Ellen Patton Totten and James Patton Totten, The Button Box: A Daughter's Loving Memoir of Mrs. George S. Patton (Columbia: University of Missouri Press, 2005); Patton and Scruby; ibid.; Patton. ${ }^{402}$ Patton, Harkins, and Patton.
} 
common soldier. Because of their pro-Patton bias and their accessibility to the general public, these books serve as primary sources that are useful to uncover the beginnings of the Patton legend.

However, there are several biographies that are particularly useful for understanding how historians became actors in the perpetuation of collective memory. As noted earlier, Ladislas Farago, perhaps the first serious biographer of Patton, presented Patton: Ordeal and Triumph as a study of the life and career of Patton and does offer some insight into the beginnings of the Patton legend. ${ }^{403}$ Martin Blumenson's Patton: The Man Behind the Legend outlined the creation of the Patton brand and the thespianism that reinforced it. ${ }^{404}$ Blumenson, the same historian who edited The Patton Papers, wrote a narrative in which he sought to penetrate the legend and examine Patton's insecurities, motivations, influences, and leadership style. ${ }^{405}$ In it, he explained the timing and meaning of the Patton legend as he interpreted it:

Between Patton's accident and death, in the space of two weeks, the American people revised their judgment of him. Had he died at once, he would probably have vanished from the public consciousness. He might have been remembered as a peculiar, an eccentric, and unbelievable and exaggerated caricature. Instead, as he fought for his life, the news media had a chance to recall at length his triumphs and featured his successes. His swashbuckling and color, his flamboyance and profanity were no longer deemed extraneous to his accomplishments. They were a part of his image, and his image in large part was responsible for his victories. As an enthralled public followed his last struggle in the hospital with sympathy, they came to appreciate his impact on the war, to be grateful for his results, to admire what he had done.... Who else could have done all that? Only Patton, who had thereby shortened the war. The understanding and applause, together with the profound grief at his death, transformed him almost at once into a folk hero, a man who was already a legend [emphasis added]. ${ }^{406}$

\footnotetext{
403 Totten and Totten; Patton; Patton and Scruby; Ayer.

${ }^{404}$ Farago, Patton: Ordeal and Triumph.

405 Martin Blumenson, Patton: The Man Behind the Legend, 1885-1945 (New York: Morrow, 1985), 14; Patton and Blumenson.

406 Blumenson, Patton: The Man Behind the Legend, 1885-1945, 301-02.
} 
For Blumenson, Patton did not outlive his era; rather he died at just the right time, while his triumphs in the war remained fresh, before he could destroy his reputation by uncalculated rhetoric.

As the most recent definitive and comprehensive history, Carlo D'Este's Patton: A Genius for War chronicled the Patton story centered on the flawed argument that a childhood challenged by dyslexia shaped his character and asserted that his success was merely a result of the combination of tactical success and showmanship. ${ }^{407}$ Stanley Hirshson argued in General Patton: A Soldier's Life that all previous works on Patton were incomplete and therefore wrote his account as both a counter-narrative and supplement to the accepted Patton story. In doing so, he unknowingly illuminated the legend more clearly. "In a real sense General Patton lived after he died," Hirshson asserted. During the aftermath of his death the stories of friends and supposed friends who desired to use the general's words and renown for monetary and political gain dominated the field. "The end of the war saw a mad dash to exploit it heroes," and so these authors were among the earliest stakeholders in the Patton legend (the first being Patton himself, then the wartime correspondents). By any objective standard, Patton was an extraordinary tactical commander who possessed imagination and an ability to visualize the entire battlefield, but his popularity within the ranks stemmed from his empathy as a leader. Contrary to the opinions of his detractors, it was difficult to find a general who cared more for his soldiers than General Patton. He was always out in the

\footnotetext{
${ }^{407}$ Ibid.; D'Este. D'Este's work, although incredibly important for Patton historiography, was based on a flawed argument that Patton's outlandish public behavior stemmed from a learning disability that made him self-conscious and his flamboyance was an attempt to compensate for a self-perceived weakness.

However, there is no empirical evidence that Patton had dyslexia, a myth promulgated by early populist biographers.
} 
cold and rain with them, seeing that they had the best food and medical attention and listening to them and talking their language. But his ambition and fame was often threatening and created jealously or umbrage, especially, as we have seen, with his peers and superiors. $^{408}$

Farago, D'Este, and Hirshson provided in-depth analyses of the Patton story but all were markedly lengthy to an intimidating degree for a casual reader. As an alternative, Alan Axelrod offered a concise account humbly titled Patton: A Biography that attempted to address the question of why Patton polarized public opinion for generations and addressed for the first time the legacy Patton left with the Army institution. $^{409}$

Aside from this small collection of reliable biographies, other works require acknowledgment as rigorous attempts at explaining the meaning behind Patton and his story. A series of analytical histories contended with military operations, particularly the Battle of the Bulge, the Lorraine Campaign, and Patton's actions in WWI. ${ }^{410}$ A few notable works described Patton's idiosyncratic way of waging war and philosophies of warfare itself. $^{411}$ Additionally, a grouping of comparative studies juxtaposed Patton with one or more of his contemporaries, with Generals Montgomery, Eisenhower, Bradley,

\footnotetext{
${ }^{408}$ Hirshson, 681-82, 700-01.

409 Axelrod.

410 Three such operational histories are: Rickard, Patton at Bay: The Lorraine Campaign, September to December, 1944; Leo Barron, Patton's First Victory: How General George Patton Turned the Tide in North Africa and Defeated the Afrika Korps at El Guettar (Guilford, Connecticut: Stackpole Books, 2018); Patton at the Battle of the Bulge: How the General's Tanks Turned the Tide at Bastogne (New York, New York: NAL Caliber, 2014).

${ }^{411}$ Examples include, but are not limited to: Alan Axelrod, Patton's Drive: The Making of America's Greatest General (Guilford, CT: Lyons Press, 2009); George A. Higgins, "Operational Tenets of Generals Heinz Guderian and George S. Patton, Jr" (U.S. Army Command and General Staff College, 1985).
} 
and Rommel being the most common. ${ }^{412}$ One work of particular importance was Nicholas Sarantakes' Making Patton: A Classic War Film's Epic Journey to the Silver Screen. This book closely examined an important driver of the collective memory of Patton. ${ }^{413}$ Lastly, James Morningstar's Patton's Way detailed the impact Patton's legacy had on policy and doctrinal development in the US Army. ${ }^{414}$

Most academic historians agree that Patton was a misunderstood soul and addressed the paradox of the Patton legend in collective memory and reality. Martin Blumenson, one of the premier Patton biographers, succinctly stated that behind the legend was a man who was shy, withdrawn, emotional, insecure, and sensitive. ${ }^{415}$ In Patton: The Man Behind the Legend, Blumenson, like many other historians, sought to penetrate the mystery and myths that surround Patton and to explain the sources of his insecurity while describing who Patton really was at his core. And of course, Ladislas Farago exclaimed Patton was not illustrative of the extremes in which the populists placed him. ${ }^{416}$

Alexander Lovelace added to the conversation with his take on Patton's use of the media to create an image that ultimately became the Patton legend. While Patton saw the usefulness of getting press attention for his soldiers, he also discovered that he became trapped in the "Blood and Guts" persona, in both positive and negative contexts. For his part, Patton used brash behavior to shock people as a studied attempt to play upon on

\footnotetext{
${ }^{412}$ For examples, see: Michael Frank Reynolds, Monty and Patton: Two Paths to Victory (Barnsley, South Yorkshire: Pen \& Sword Military, 2010); Terry Brighton, Patton, Montgomery, Rommel: Masters of War (New York: Crown, 2009); Dennis E. Showalter, Patton and Rommel: Men of War in the Twentieth Century (New York: Berkley Caliber, 2005).

${ }^{413}$ Nicholas Evan Sarantakes, Making Patton: A Classic War Film's Epic Journey to the Silver Screen (Lawrence: University Press of Kansas, 2012).

${ }^{414}$ Morningstar.

${ }^{415}$ Martin Blumenson, Patton, The Man Behind the Legend, 1885-1945 (New York: Morrow, 1985), 14.

${ }^{416}$ Farago.
} 
youthful imaginations. The media, Lovelace argued, relayed to consumers Patton's performances, creating "a distorted image [of Patton] that persists to this day." ${ }^{\text {417 }}$ During the large combat maneuvers in the South in 1941, Patton rode into the public's imagination atop a red, white, blue, and yellow striped tank. He was the colorful military figure the media needed to garner support for the war effort. To be sure, "the media did not create the image of Patton that emerged," it only propagated it into folk hero status. ${ }^{418}$ Much to his dismay, Patton ultimately became the persona he acted out, believing that if he didn't live up to the hype his men would lose faith in him.

Conversely, historian Nicholas Sarantakes asserted that the legend began with the movie Patton (1970). For Sarantakes, when most people think of the general, "the image that immediately comes to mind involves George C. Scott, a forty-one-year old former Marine with a gravelly voice, rather than the sixty-year-old who spoke with a thin voice and a slight Southern accent." Admittedly, Patton's “success - which was legendary was no accident. ${ }^{» 19}$ For Sarantakes, Patton's legacy and legend were inseparable from the film. However, for most Patton historians, with Sarantakes as an outlier, the end of the war saw a mad dash to exploit its heroes. Among them, Patton was front and center. In addition to offering explanations of the legend and its sources, these historians also detailed evidence of Patton's fame. For example, most historians wrote that Patton's popularity was illustrated in the attitudes of troops under his command. Sarantakes claimed that the success of the movie Patton, nominated for 10 awards including best picture and best actor in the 1971 Oscars and considered by film critics as one of the best

\footnotetext{
${ }^{417}$ Lovelace, 108.

${ }^{418}$ Ibid., 109.

${ }^{419}$ Sarantakes, 8 .
} 
100 pictures ever made, not only served as a driver of the legend, but is the ultimate evidence of Patton's popularity. ${ }^{420}$ Lovelace took a different approach by looking at the media and public opinion. Throughout a barrage of criticism from news sources, the American public continued to support Patton as seen through a Gallup poll released in December 1943 which stated 70 percent of Americans believed Patton should retain command of his army after the slapping incidents in Sicily. Reporters ultimately wanted to follow Patton because of his colorfulness. ${ }^{421}$ D'Este showed that further evidence of Patton's fame could be seen from the twelve hundred attendees at his memorial service that included General Dwight Eisenhower and Secretary of War Henry Stimson. ${ }^{422}$

While detailing the meaning and cause of the Patton legend and providing indications of his popularity, these same historians also argued that the myth and legend were overblown. Farago stated that Patton "was no dreamer of vast human schemes" but was a leader whose "aspirations did not extend to the betterment of mankind.... If Patton never lived, the world would not have missed him." Yet, Farago continued, Patton was "a superb professional with a volcanic inner drive that pushed him on when others chose to halt" and was "a skilled, imaginative, and dynamic practitioner of his craft.... In this context, his enduring significance cannot be overstated. ${ }^{\$ 423}$ Historian Alan Axelrod countered that narrative by arguing Patton was not simply a masterful tactician - his tactics actually became strategy. One needs only to look at the operations in Iraq in 1991 and 2003, which both employed a "Pattonesque ground advance," to see the influence of

\footnotetext{
${ }^{420}$ Sarantakes, 8 .

${ }^{421}$ Lovealace, 114, 16.

${ }^{422}$ D'Este, 804.

${ }^{423}$ Farago, Patton: Ordeal and Triumph, 847.
} 
the general's tactics on current Army strategy. ${ }^{424}$ Lost in the legend were other aspects of Patton's success. For example, D'Este posited that Patton was a complete student of military history who should be remembered for his achievements as a trainer of troops and as an innovative tactician and prolific military writer. ${ }^{425}$ Axelrod agreed. "Patton's greatest value" was "as a trainer of soldiers rather than a combat leader." 426

These historians documented contemporary criticism leveled against Patton, which included his handling of the Vichy French in Morocco, the slapping incidents in Sicily, the Knutsford affair, and his reluctance to enforce Eisenhower's denazification program. However, they also agreed that all was forgiven at the point of his tragic death on December 21, 1945. The controversies ended the day Patton died, Axelrod added, which were "swept aside, if not forgotten, in a rush to depict Patton as a very great general, perhaps the greatest of World War II.... During the bewildering and anxious aftermath of World War II...the popular image of Patton as a heroically simple and direct man of action became most seductively appealing." ${ }^{427}$

Although they interpreted the meaning of the Patton legend, few historians touched on the issue of his legacy, or the lasting impact his career had on the U.S. Army as an institution. Axelrod devoted one chapter to the subject in perhaps the first serious attempt to go beyond the Patton legend and myth. Axelrod pointed to the conduct of military actions in Korea, Vietnam, and the Cold War (he differentiated the proxy wars from the Cold War), stating that these conflicts were in many ways the legacy of Patton. His tactical vision for maneuver warfare suffused the post-World War II U.S. Army,

\footnotetext{
${ }^{424}$ Alan Axelrod, Patton: A Biography (New York: Palgrave Macmillan, 2006), 176-77.

${ }^{425}$ D'Este, 811.

${ }^{426}$ Axelrod, 181.

${ }^{427}$ Ibid., 174.
} 
influencing combined-arms warfare and doctrine. The Army even named the first series of postwar tanks after Patton. Numerous posts dedicated Patton Halls, Patton barracks, and one post, Fort Knox, constructed a Patton Museum. Beyond all of this, his character exerted a magnetic pull on the officer corps, particularly in the armor and cavalry branches where Patton became lionized. Patton, Axelrod exclaimed, bequeathed to the Army a new definition of command presence, military professionalism, and leadership. Updated ideas on the uses of armored cavalry, combined arms approach, reduction of collateral damage, and realistic training were also part of the Patton legacy for the Army today. ${ }^{428}$

Finally, with James Kelley Morningstar's Patton's Way: A Radical Theory of War (2017), an honest attempt to address the contradiction between the historiographical criticism of Patton's methods and popular appreciation for his success and a thorough analysis of his legacy for the U.S. Army became available. Of all the academic works on Patton, Morningstar offered the only in-depth analysis on Patton's place in the military's institutional memory. The secret to Patton's success, he asserted, was a radical and purposefully crafted doctrine developed over multiple decades. His principles directly contradicted official Army doctrine at the time, a widely accepted model that rejected a focus on tactical battle and focused on the use of infantry, top-down command and control, detailed orders processes, and a small-scale intelligence gathering apparatus limited to supporting preconceived plans. Because Patton's methods did not conform to established policy, his peers rarely understood them, resulting in misinterpretations of his intent and actions. Although Patton's way of making war was systematically

${ }^{428}$ See the final chapter in Axelrod's Patton: A Biography, 174-182. 
deconstructed from Army operational doctrine, which reverted back to attrition-based warfare and overwhelming firepower tactics during Korea and Vietnam, the Army's Armor School allowed Patton's ideas to take root. Patton's way became the AirLand Battle doctrine of the 1980s which allowed for the quick annihilation of Iraqi forces in Desert Storm. ${ }^{429}$

The historiography on Patton, like the earliest biographies, also reveals an attempt to describe Patton's final place in history. If professional historians said the same types of things about Patton as did the populists, perhaps there was some truth to the story. For Blumenson, Patton ranked with the world's great army commanders and is the greatest and most inspiring combat general of modern times. ${ }^{430}$ D'Este claimed that although "opinions of his place in history have varied from outright condemnation to oversimplification and unadorned praise," Patton's place in history is merely as a soldier's general, who "will lie in the midst of men who died in what he regarded as a noble calling." ${ }^{431}$ Considering the Patton legacy first described by Axelrod and later detailed by Morningstar, Patton's place is not entirely in history at all - he continues to inspire current generations of military personnel. Historians agreed that Patton was widely known for his eccentric behavior and his battlefield victories, making him one of, if not the most, popular generals in U.S. military history.

The memory of Patton carried on through the myth and legend, and even though his life is over, the messiness of historical memory continues. Figures of myth largely represent the meaning we endow them with. While historians attempted to describe the

\footnotetext{
${ }^{429}$ Morningstar.

${ }^{430}$ Blumenson, Patton, The Man Behind the Legend, 1885-1945, 11 and 302.

${ }^{431}$ D'Este, 811.
} 
legend and its beginnings, they left out of their argument vast arrays of evidence and none attempted to describe the meaning embedded in the symbol Patton became. They did try to dispel some of the myth, but in doing so inaccurately claimed that Patton was merely a great tactician whose transgressions were forgiven upon his death. For these historians, Patton claimed an exalted place in history. Yet only Axelrod and Morningstar touched the Patton legacy, who admitted that Patton rightfully entered into American mythology, but the mythical Patton all too readily overshadowed the historical Patton. ${ }^{432}$ A particular form of narrative arose quickly after Patton's burial that had an outsized impact on collective memory and did much to keep him in the public eye: conspiracy theories. Immensely popular, these tales of nefarious deeds by envious contemporaries, left-wing communist ideologues, and worried politicians did as much to obscure history as they did to breed animus. Regardless, the memory stakeholders in these cases, much like the early biographers, stood much to gain in book deals and movie ticket sales.

Conspiracy theories are popular indeed, and those involving Patton's death are no different. Conspiracy theorists, for a variety of mostly ideological and political reasons, persist today and those who originated the ideas wasted no time in pushing them. They were plentiful and popular, especially in the context of the ending of World War II and the beginning of the Cold War. Farago wrote, "The death of George S. Patton, Jr. at Yuletide in 1945 has become second only to the assassination of John F. Kennedy and Martin Luther King, Jr., in controversy and obfuscation.” Beginning while he was in the hospital within hours of his death, rumors rounded Europe that Patton was the victim of

\footnotetext{
${ }^{432}$ See Axelrod and Morningstar.
} 
premeditated murder in a sinister plot to get him out of the way of senior military officers, Soviet officials, or Nazi diehards. ${ }^{433}$

Several factors opened the door for conspiracy theory narratives - stories that asserted Patton was assassinated in an elaborate plot in which, some implied, General Eisenhower played a part. ${ }^{434}$ First of all, the Military Police began but did not submit or close an official vehicle accident report because by the time they arrived on the scene, the officer in charge believed there was nothing to report and considered the accident a trivial matter. A point ignored by conspiracy theorists, it was Patton who told Lieutenant Babalas, the Military Police officer first on the scene of the accident and who served as the investigating officer who later visited Patton in the hospital, "I want to say that this here was a stupid accident - only an accident! Neither of the drivers was responsible for what happened!"435

It is true that Patton's accident was poorly documented at the time and remains so today. Conspiracy theorists keyed in on previously vague or unreported details and pushed their speculation as evidence, such as one argument published in After the Battle magazine in 1975, which included photographs of the scene. As with the death of other famous public figures, Patton's accident "spawned a myriad of myths, gossip, speculation, and outright fabrications by opportunists who would profit from such an event." ${ }^{436}$ The question is, who were these people who had a stake in the conspiracy theory version of public and collective memory?

\footnotetext{
${ }^{433}$ Farago, The Last Days of Patton, 1-2.

${ }^{434}$ Ibid., 786.

${ }^{435}$ Ibid., 9,11.

${ }^{436}$ D'Este, 786.
} 
Finding a motive for a conspiracy theory was not difficult. As the story went, Patton's superiors had several reasons to get rid of him, such as their belief that Patton became pro-German since the ending of the war. Indeed, he declared once that the Army should rearm the Germans and make them allies in the fight against the Soviets. He was intent on provoking a clash with the Soviet Union - as long as Patton was around, "the specter of World War III would haunt the world." ${ }^{237}$ Certainly, the Allies, particularly the communists who were unable to logistically support their own war against Nazi Germany without help from the Americans, had reason to avoid conflict. Postwar politics, particularly the fight over how to divide responsibilities in occupied Germany, was an easy grab. The battle over end-of-war legacies could also be a plausible basis for such a narrative. Or, alternatively, there was money to be had. Whatever the reasons for the conspiracy theories, one thing is certain: they sold books and movie deals.

Farago asserted that the belief in Patton's nefarious ending was invented by a group of former Nazi officers who had visions of a triumphal return to power. It was their "second-best prospect of one day snatching victory from the embarrassment of defeat." These individuals hoped to create the infamous redoubt in the Austrian Alps where Nazi party cadre, government personnel, and the SS, supported by a hoard of gold, would reconstitute the Third Reich. That plan failed, largely due to Patton and the Third Army whom Eisenhower sent to prohibit it. But Patton admired German discipline and industry. He appeared to the Germans as a potential ally because of his shared distrust and disdain for communists, and Nazi diehards learned of his attitudes by establishing themselves into Patton's entourage in the guise of Baron von Wangenheim, a former

${ }^{437}$ Farago, The Last Days of Patton, 2. 
German cavalry officer who became the groom of Patton's horse stable and his horse riding companion. According to this trope, communist sympathizers killed Patton in order to prevent the rearmament of Germany as allies in a war against the Soviet Union. ${ }^{438}$

Other stakeholders were book authors and movie producers who clearly had money and prestige to gain. In particular, two British writers gave one particular conspiracy theory traction and respectability, with Field Marshall Montgomery as the "spiritual source of the anti-Patton campaign." The British allegedly had an inferiority complex after the war and pushed the Nazi conspiracy theory that "blossomed into a British plot and eventually spread to millions throughout the world," leading to a book written by Christopher Leopold with the personally affronting title Blood and Guts is Going Nuts.

Leopold used real names for the Americans (Patton, Ike, Gay, Bedell Smith) and "spun his yarn around them, giving a semblance of authenticity to the figments of his imagination." This theory asserted that a Bavarian billionaire tried to get Patton to attack the Soviets and make a dash to Moscow. No Britons appeared among the principal characters while the Germans were cushioned from the author's sardonic bent and were given pseudonyms. When the book reached the United States, it was described as a "black comedy of politics and paranoia" and book reviewers at Doubleday Publishing, the largest American publishing company after World War II, advertised the book as "A bawdy, rollicking tale about the first few months of so-called peace in Europe." ${ }^{439}$

\footnotetext{
${ }^{438}$ Ibid., 3-4; Christopher Leopold, Blood and Guts is Going Nuts (London: Lemon Tree Press, 1976).

${ }^{439}$ Farago, The Last Days of Patton, 5.
} 
Leopold's book vanished shortly after publication but it paved the way for the motion picture Brass Target (1978), produced by Metro-Goldwyn-Mayer (MGM) and loosely based on the book Algonquin Project by Frederick Nolan. Nolan used pseudonyms for his characters and changed some dates. In the making of the movie, MGM created a dossier titled "Conspiracy Research Manual." The director, John Hough, an Englishman, wrote, "Patton's death is part of a conspiracy and I intend to leave very serious doubts in the minds of the audience about the General's death being merely an accident." MGM's exploitation of the conspiracy theory originated in its London-based international publicity directorate along with a dozen public relations personnel with the expressed goal of raising skepticism. "[T]he world believes that General George S.

Patton died following an automobile accident. But was it an accident? Conspiracies and cover-ups continue to fascinate the media. Brass Target offers both and we should take full advantage of this two-pronged opportunity to call attention to the film." Their main source of evidence was purely a speculative idea: there was no way a simple automobile accident could have caused that much damage to the Cadillac. ${ }^{440}$ Brass Target was a miserable failure at the box office but that did not spell the end for conspiracy theories.

The concept of Algonquin Project was that a group of Eisenhower's friends groomed him for the presidency but they feared Patton might do or say something that would jeopardize his chances. President Truman, General Eisenhower, and a Soviet NKVD (The People's Commissariat for Internal Affairs, precursor of the KGB) agent planned the successful assassination of Patton in order to stop World War III and set

\footnotetext{
${ }^{440}$ Ibid., 6-7; Frederick W. Nolan, The Algonquin Project (New York: Morrow, 1974). At the time of the accident, Patton's Cadillac traveled at 35 miles per hour. Images of the car after the crash show extensive damage to the front fenders and grill. In fact, the engine had to be replaced.
} 
Eisenhower up for a run at occupying the White House. The Americans hired an assassin through the aid of Mafia godfather Lucky Luciano while he was in prison. As this conspiracy theory went, at the moment a decoy truck crashed into the Cadillac, a sniper fired a rubber bullet that hit Patton's head and broke his neck. There was a subplot as well that suggested the theft of a huge hoard of German gold by high-ranking American officers was about to be discovered by Patton who took personal charge of the investigation. The gold belonged to the Russians, who held Patton responsible for the theft. $^{441}$

Who Killed Patton?, written by an imaginative individual prone to conspiracy theories, a medical doctor who served in Europe during World War II, served up another tale of nefariousness. Although advertised as fiction, "purely an amusement, not meant to indict, criticize, or raise new speculation," innuendo and outright assertions discredited the marketing scheme of the book. ${ }^{442}$ In this particular plot, a colonel on Patton's staff who had no prospects for employment after the war, used a clandestine unit to find a hoard of gold and tried to use it to raise an unauthorized army of former SS commandos with the intent of invading Russia. Patton was not aware of the scandal but wanted to turn in the gold to his superiors. An assassin in the colonel's unit shot Patton with a rubber bullet that made it appear he died from the car accident. In the last pages, the author offered his sources of speculation. Why was Patton assigned a new driver? Why was a 2.5-ton army truck out of its motor pool on a Sunday morning? Why did the driver of the truck vanish after he attempted suicide? Why was Patton the only person injured in such a moderate accident? Why did the military police report vanish? Why was no

${ }^{441}$ See The Algonquin Project and Brass Target.

${ }^{442}$ Ferdie Pacheco, Who Killed Patton? (Indianapolis, IN: AuthorHouse, 2004), vii. 
autopsy performed? Why was there no crime scene investigation? Of course, there are plausible answers to these questions, all of which the author conveniently ignored.

Similarly, in Target Patton, Robert Wilcox offered another conspiracy theory in which he argued that a Russian NKVD agent carried out the assassination plot in order to stop World War III, an eventuality if Patton were left alive. The assassin used a truck to kill Patton but botched the attempt. Later, another agent snuck into the hospital where Patton recovered and administered poison to him. Wilcox also claimed that William Donovan, the head of the Office of Strategic Services (OSS), the precursor to the Central Intelligence Agency, might have been involved. ${ }^{443}$

D'Este noted that in 1987 a former soldier named John Enigl asserted in an article titled "Death of Patton" in Military magazine that Enigl was the first on the scene of the accident. However, Enigl named the wrong location of the accident, claimed General Hobart Gay was not present, and that Eisenhower shook his hand after Patton's funeral, although Eisenhower was not at the funeral but left the ETO for the United States a month earlier. Another former soldier named Douglas Bazata claimed in the Baltimore newspaper Spotlight (January 4, 1993) that William Donovan hired him to assassinate Patton. However, someone else finished the job before him using a specially designed Czech weapon that fired a piece of metal making his injuries appear to have been the result of the car crash. When Patton did not die, the assassin allegedly slipped into the hospital and gave Patton cyanide. ${ }^{444}$ It is easy to see the connection between this conspiracy and that which Wilcox concocted.

\footnotetext{
${ }^{443}$ Robert K. Wilcox, Target: Patton: The Plot to Assassinate General George S. Patton (Washington, D.C.: Regnery Publising, 2010).

${ }^{444}$ D'Este, 787.
} 
The most recently published and most widely read version of a conspiracy theory was Killing Patton: The Strange Death of World War II's Most Audacious General by Bill O'Reilly and Martin Dugard. O'Reilly and Dugard boldly claimed that they were not conspiracy theorists and wrote from a factual point of view with no agenda. ${ }^{445}$ Actually, quite the opposite was true: the book was replete with untruths, misinformation, insinuations, and innuendos. For example, the authors claimed that Patton slept in "mansions, palaces, castles, and five-star hotels" because he was accustomed to luxury (he did make his headquarters in those places but chose to sleep in his converted smallarms repair truck) and that a man who was revered and feared such as he surely had many enemies. Patton did have competitors and many officers were envious of his position and abilities, but none despised him to the extent of extolling murder. For the most part, Patton was highly regarded: a man of lesser talent would not have been retained after his emotional outbursts and lack of tact. His superiors had several opportunities to rid themselves of the impetuous officer, but declined. They knew that the lack of Patton's presence on European battlefields could spell disaster. Yet, the authors claimed that Patton had "many high-ranking enemies in Moscow, Berlin, London, and even Washington D.C." ${ }^{446}$ The authors did not present any real evidence other than speculation supporting this assertion. Furthermore, they disregarded all plausible explanations for the lack of an autopsy and why the military police did not complete their report. These facts are documented, but that of course would discredit the story far too quickly. Several innuendos in the book bolstered their sensational story, such as a

\footnotetext{
${ }^{445}$ Bill O'Reilly and Martin Dugard, Killing Patton: The Strange Death of World War II's Most Audacious General (New York: Henry Holt and Company, 2014), 309.

${ }^{446}$ Ibid., 2.
} 
statement that the truck Patton's driver hit swerved inexplicitly as if intentionally trying to hit the Cadillac, an assertion that runs counter to all eyewitness accounts.

Structurally their narrative spun off in multiple directions, abandoning the crux of the story early and often with only periodic returns to Patton and no direct ties to his actual death. Somehow, Hitler, Stalin, Churchill, Roosevelt, and Truman join forces with an unlikely cast of characters that included an army private, a holocaust survivor, and William Donovan. The authors never made a true connection between any of these individuals save for a few loosely relevant instances in the story. There were no footnotes so outlandish claims cannot be referenced. As a method, the authors took advantage of an emotionally charged political and ideological climate along with the collective and public memory to tie together loose vagaries. To generate continued interest in the book, and perhaps to steer readers' attentions away from the fact that only about half of the book directly addressed the Patton story, the authors used outlier stories to suck readers further into the narrative. Hitler's uncontrollable flatulence along with the alleged extramarital affair between General Eisenhower and his driver Kay Summersby somehow came into account, as well as an alleged affair between Patton and his niece, Jean Gordon. Did they insinuate that Patton's wife, or Jean, had Patton killed? What do these assertions have in relation to Patton's death? In a word: nothing. Patton did controversial things and behaved in a way that irked his superiors. Others became annoyed with Patton, like General Marshall and many politicians in the States. Patton died suddenly and therefore all of those who were less than amused with Patton's antics and outlandishness were implicated in Patton's death in the book. The authors also attempted to foster dislike and distrust of England and Russia equally. 
Churchill and Stalin were named as possible antagonists in the conspiracy theory (along with President Roosevelt whom they tied to the CIA, Gestapo, and KGB), yet there was no explanation as to how they were involved. "Patton knows too much" and "he must be silenced" are speculations the authors used in the melodrama along with contemporary fears of a Patton political run. ${ }^{447}$ While the book pits Patton against Eisenhower in a contingent battle for the White House, Patton had no desire to enter politics, nor was it evident that Eisenhower did at that time.

Patton had many near misses in the war, for sure, but that does not mean there was a plot to kill him. Take, for instance, the tale of the Polish fighter pilot in a Spitfire who mistakenly fired on Patton's observation plane. According to O'Reilley and Dugard, it was "either a case of mistaken identity or a bold attempt at murder." 448 Yet, if it were an assassination plot, they did not argue effectively how the Polish fighter pilot even knew Patton was in the plane. Another claim in the book centered on a bizarre figure, Douglas Bazata, the same person cited by D'Este, who claimed later in life (1979) that he assassinated Patton in collaboration with OSS Director William Donovan.

In Killing Patton, the account of the actual accident was fraught with holes. For example, the authors claimed there was no motor pool near where the truck swerved, cutting off Patton's Cadillac, an argument based on the statement by Patton's driver, who said, "I don't know where the truck was going." ${ }^{449}$ They also falsely claimed that there was no attempt to speak to Patton in the hospital. The facts that there are photographs and video of the motor pool and that Lieutenant Babalas, the military police lieutenant in

\footnotetext{
${ }^{447}$ Ibid., 285 and 33, respectively.

${ }^{448}$ Ibid., 241.

${ }^{449}$ Ibid., 302.
} 
charge at the scene who later visited Patton in the hospital to ask for his version of the events (when Patton told Babalas to drop the investigation), did not factor into the narrative. Instead, O'Reilly and Dugard fabricated an elaborate, if disjointed, conspiracy theory, one that was the fifth best-selling printed book in 2014 and which sold well over one million copies. ${ }^{450}$

None of the conspiracy theorists provided even the slightest evidence of how an assassination plot was possible without knowing Patton's agenda for the day or ensuring a train would stop Patton's Cadillac. The perfunctory investigation by the Army and Mrs. Patton's refusal to allow an autopsy on her husband's body opened the door for such conspiracy theories. After Farago attempted to dispel the conspiracy theories, Lieutenant Babalas, the reporting officers who concluded that both drivers were careless, became a Virginia state senator and wrote the Pentagon looking for his report of the accident. No copy was available, all being forever lost. Certainly there remained questions as to the handling of the accident.

Undoubtedly, the immense popularity and pervasiveness of these conspiracies further illustrates the hold Patton continues to have on the public's imagination and are very much a part of the collective memory, first shaped by Patton himself, his subordinates, World War II journalists, then later populist biographers and historians. ${ }^{451}$ But with as much influence conspiracy theorists had on shaping the narrative and increasing Patton's popularity, they did not overshadow the preponderance of evidence left by memory workers as they created a public version of the Patton collective memory.

\footnotetext{
${ }^{450}$ Clare Swanson, "The Bestselling Books of 2014," https://www.publishersweekly.com/pw/bytopic/industry-news/bookselling/article/65171-the-fault-in-our-stars-tops-print-and-digital.html.

${ }^{451}$ D'Este, $786-87$.
} 


\section{CHAPTER VI}

\section{A PUBLIC MEMORY}

It is better to live in the limelight for a year than in the wings forever. General George S. Patton, Jr.

Newsprint and books contributed to the establishment and perpetuation of the collective memory of Patton within the public writ large. Immediately after Patton's death, however, several physical manifestations of that collective memory appeared in the forms of memorials, commemorations, ceremonies, exhibitions, and dedications that were visible publically and shared by specific populations. Additionally, the formation of societies dedicated to the memory of Patton indicated there were certain collectives that intended to preserve the Patton legend in its public form. There is nothing automatic about the past entering public record. Deliberate manifestations of memory work at the collective level that reside or take place in the public sphere, such as those listed above, provide a point of departure for discussing those aspects of the past that identifiable groups deemed important and meaningful. Wartime journalists wanted to give hope and sell newspapers and authors also capitalized on Patton's fame in terms of books sold. The motives of those who create physical memory markers, however, are often not as overt. Public memory defined here is the purposeful engagement of the past in a public setting, when and/or where communities engage with the past symbolically. The engagement partly consists of a shared sense of identity and is fraught with ideological 
implications that are often the fodder of political conflagration. ${ }^{452}$ Collective memory can be captured in a book, in films and documentaries, and in monuments and museums, but when acted upon publicly the collective memory takes on a more sociological function. Put another way, all public memory projects are representations of collective memory, but not all aspects of collective memory are public.

While related, the distinction between collective and public memory merits some further attention here. On the macro level, collective memory may reside within populations of people with countless personal or group identities but serves as one marker of an overarching shared identity, even if individuals have little to nothing in common with each other besides the shared memory. Public memory is typically constitutive of identities more easily defined, such as national, regional, or recognizable group identity. There is little in our life that is untouched by public memory even if we do not focus on it except during ceremonial occasions. Our individual and shared sense of public identity carries forward meaning found in fixated public memory sources, as in the example of monuments. This identity specifies what kind of citizens we are and our belongingness to a group and signals to others what the cultural values of that particular population are. ${ }^{453}$ There are two ways memory scholars frame the phrase "public memory." First, there is a shared memory held and maintained by a particular public, or what I refer to as collective memory. Then there is the "publicness" of memory, the framework of remembrance addressed in this chapter. The assumption inferred here is that there is such a thing as a public and those publics share memories, or at least the capacity for remembrance. Indeed, this is a defining characteristic of a public (or as I

\footnotetext{
452 Phillips, 90.
}

${ }^{453}$ Ibid., 37-38. 
will argue later, a collective). Public memories therefore are representations of collective memories that are visible to many. They have common characteristics with collective memory in that they both allow for inspiration and are open to future interpretations of meaning through an ongoing interchange of ideas, thoughts, opinions, and beliefs. But unlike collective memory, the concepts of place and action are paramount. Public memory typically occurs when people meet and interact. That particular place lends itself to remembrance and facilitates it. Sometimes it embodies the memory itself, such as memorials, battlefields, or other historic sites. Other times, it occurs in the digital sphere, such as social media platforms. Place is more than a matter of setting - rather, it is a question of an active inducement, its power of drawing out appropriate memories and responses in that particular location, whether that place be physical or otherwise. It is not for the sake of intimacy, but for the sake of a public presence that can only be accomplished when people congregate for a common purpose. When those people disperse, public memory reverts back to collective memory. Public memory requires an inter-human presence, a form of community, no matter how brief. ${ }^{454}$

Because public memory is typically the visible manifestation of collective memory, the physical evidence of public memory may serve to illustrate the extent to which there was and is a collective memory of Patton, what the political motivations of the memory workers were in the quest to perpetuate that memory, and allows for tracing the trajectory of the collective memory through time and location. Public memory needs a place to enact memory, a scene of instantiation that arises and lasts. Without a concrete (including digital - things posted on the Internet may be more permanent than a

${ }^{454}$ Ibid, 31-32. 
monument) emplacement, public memories would have no referent in reality. Public memory "takes aim to take place." 455

One such form of public memory is remembrance, the outward expressions of memories undertaken so they may not be forgotten entirely. Perhaps the most notable form of remembrance for Patton came in the form of his funeral and burial. Less nuanced or involved than other forms of public memory (like commemorations, addressed below), remembrances are nonetheless public performances intended to endow a specific memory with some level of permanence in the public sphere and often take place around sites of public memory like memorials. Remembrance, a capacity captured by Mnemosyne, the mother of all muses, demonstrates this ancient desire. ${ }^{456}$ Of course, within every society there are subsets of people who attempt to maintain or resist projections made by memory workers just as there are those with hegemonic tendencies who attempt to inscribe memories in stone and fix narratives of the past immutably in adherence to their own agendas. But, because publics tend to enact memory through repeated acts like remembrances, those performances ensure the future of a collective memory.

There are a plethora of different spaces, objects, and texts that make engagements with the past possible. The process of collective memory includes the prioritization and recognition of obligations, goals, and intended audiences. Even with a minimum of public discourse, the very presence of community involvement provides clues as to what is going on and what is important to a group, although who deems the past important and

\footnotetext{
455 Ibid., 38-39, 42.

${ }^{456}$ Mnemosyne was the ancient Greek goddess of memory. The etymology of the name has mnemonic as its source, the meaning of which is "remembrance." In one of the ancients' more compelling ideas was the notion that inspiration (the Muses) came from memories or remembrance.
} 
why is not always apparent. Likewise, the values of a group can be gleaned from the act of social forgetting - people learn to regard the past not as a constraint but as a condition of possibility for the present and future while forgetting those parts of the past that are not useful or are deemed not worthy of a place in collective memory. ${ }^{457}$ What has been included and excluded in the hierarchy of memory is of equal importance to understanding the collective memory of a culture, but it is important to remember that public manifestations of memory were created with the anticipation that the things purposefully remembered were in danger of being forgotten. ${ }^{458}$ It is rare to not encounter some physical markers that aid in the process of collective memory. The production of symbolic resources makes certain forms of engagement with the past possible but those forms of public memory do not predetermine the uses for which those resources are used. In fact, a great deal of the traces of memory lay dormant and unattended. However, while cherished mementos of trips we took in our personal past do not need to have our constant attention to know they are there, we nevertheless keep them around for comfort. Likewise, the memories attached to those mementos do not require constant attention just because we do not routinely engage with memory does not mean those memories do not exist for recall. Everyday social practices need not involve drawing from the storehouses of our memory, collective or personal, but when we do draw on them our sense of the past is activated. Memory then becomes remembrance. ${ }^{459}$

Almost all aspects of remembrance are open to dispute, both during construction of the collective memory and it subsequent uses, revisions, and dismantling. While there

\footnotetext{
${ }^{457}$ Phillips, 208.

${ }^{458}$ Irwin-Zarecka, 115.

${ }^{459}$ Ibid., 13-14.
} 
is often the presence of social and political control over memory, efforts to define the meaning of the past also claim the power to do so. Politically motivated memory work can risk remembrances that are embroiled in ideological battles too complex for the media to handle and for the public to make sense of, risking the potential to sanitize the records of the past for the sake of inspirational value. ${ }^{460}$ The collective memory of Patton he and others established during his life won the narrative battle at first and maintained over time but did devolve into variations in the public sphere that reflected the changing priorities of the public and the Army. Varying forms of public memory served as a means to preserve some of the original symbolic texture while looking at it from current perspectives. Securing remembrance means symbolically representing a perspective while calling upon the public to pay attention. Words and texts may not be sufficient, however. Often, museums and monuments are the chosen medium for remembrance. These places, by their very nature, are a type of symbolic shorthand, an abbreviation of what longer texts say, and demand careful deliberation on detail and location with the intent of drawing reflection from viewers. Like art, self-reflective representations of the past call for certain feelings and guide ways of remembering. ${ }^{461}$ Monuments and rituals, on the other hand, evoke emotional responses. On the continuum between knowing and acting, history is legitimized and guided by principles of scientific inquiry; at the other end is memory, secured by powers of performance. In between lies a vast area of storytelling that claims our attention by virtue of the quality and significance of the story itself. Those that acquire permanence in the public sphere are judged worthy of

\footnotetext{
${ }^{460}$ Ibid., 134.

${ }^{461}$ Hugh H. Genoways, ed. Museum Philosophy for the Twenty-first Century (Lanham, Maryland: AltaMira Press, 2006), 235-243.
} 
remembering and knowing about. ${ }^{462}$ Symbolism plays a heavy part in ritual and collective identity while mixing original and contemporary meanings, securing a new presence for the past and ensures the collective memory's survival. ${ }^{463}$

To illustrate the point, Ettlebruck, Luxembourg, which calls itself "Patton Town," held a Patton Remembrance Day ceremony every year from 1954 to 2004 and is evidence of the use of the Patton collective memory as a political and community-building tool. Archival evidence from events on July 8, 1956, June 22, 1959, June 10-12, 1961, July 3, 1963, June 27, 1965, and again on June 25-26, 1966 demonstrate that the U.S. military benefited from such commemorations, in addition to the local community. The events coincided with parades in which thousands of civilians and military personnel from all over Europe participated and watched. The ceremonies also included drill team demonstrations, military band performances from countries such as Canada and France, aircraft flyovers, static weapons displays, and air assault demonstrations, presumably all public demonstrations of NATO military power during the height of the Cold War. On May 16, 1954, Prince Felix of Luxembourg unveiled a Patton Monument in the city. Additionally, the city government of Ettlebruck placed bronze plaques and erected a 3.5 meter tall statue of Patton on June 28, 1970, as well as a Patton Day War Memorial plaque in Patton Square at which officials conducted wreath-laying ceremonies at each remembrance event. Even religious institutions got into the act: there was a catholic mass held at the local St. Sebastian Church during each ceremony. ${ }^{464}$ The General Patton

\footnotetext{
${ }^{462}$ Sharon Macdonald and Gordan Fyfe, eds. Theorizing Museums (Oxford, U.K.: Blackwell Publishing, 1999), 45-63; Irwin-Zarecka, 158.

${ }^{463}$ Emile Durkheim and Karen Fields. The Elementary Forms of Religious Life (New York: Free Press, 1995), 9; Irwin-Zarecka, 137-38.

${ }^{464}$ Photographs, U.S. Army Signal Corps, Patton Day Remembrance Events, Ettlebruck, Luxembourg, Photographs. See blue binder A-14 in the Patton Archives at the General George Patton Museum.
} 
Memorial Museum opened on July 7, 1995, which "pays tribute to General George S. Patton, Jr., whose $80^{\text {th }}$ Infantry Division liberated the town of Ettlebruck on 25 December 1944," and displays a Model 1913 "Patton saber" and Patton-related ephemera. ${ }^{465}$ The citizens of that small country still consider Patton their liberator from the scourge of Nazi Germany. ${ }^{466}$

As in Ettlebruck, public memory takes concrete form and demonstrates the importance of place. This type of public and collective memory regarding Patton manifested mainly in the United States and Europe. As one historian noted, Patton's "image as a protector and liberator persisted in Europe. The British named a Rhine bridge for him; the French planned a commemorative highway stretching along his battle route from Normandy to Metz; a street in Nancy, France, was named after him; and Luxembourg issued commemorative stamps with his image on them. In America, a memorial window was dedicated to him in the Church of Our Savior in San Gabriel, California" and there were proposals for a national monument from some prominent citizens and politicians. Several states erected memorial statues commemorating the memory of Patton as an invincible warrior, terrible in battle, yet an honorable fighting man. ${ }^{467}$

Others noted the preponderance of Patton imagery. "Statues, busts, and paintings of him are scattered from Boston to the Virginia Military Institute to the Veterans Center on Park Avenue [Worcester, MA].” The former Administration Center of the United States Army Cavalry School at Fort Riley, Kansas, which moved to Fort Benning,

\footnotetext{
465 "General Patton Memorial Museum," https://www.patton.lu.

${ }^{466}$ Lande, 279.

${ }^{467}$ Linenthal, 44.
} 
Georgia, still bears his name, as does a bridge near the bomb-shaken cathedral landmark of Cologne, Germany. Lafayette College in Easton, Pennsylvania established a library as a memorial to him, and although not buried there, Patton Drive lazily leads visitors through parts of Arlington National Cemetery. ${ }^{468}$

Many of the sources of Patton public memory within the United States deal with a sense of place, marking those locations were Patton's path crossed. At Fort Benning, Georgia, there was a plaque on the house where the Patton family lived while stationed there, noting that it was first occupied by then Major General George S. Patton, Jr. and his wife, Beatrice, from May 17, 1941 to April 15, 1942. ${ }^{469}$ Also located at Fort Benning are Patton's sleeping quarters and headquarters he utilized prior to U.S. involvement in World War II. The buildings were refurbished in a World War II-era barracks company street in which visitors can walk and experience life during that period. The U.S. Army Marksmanship Unit also dedicated a building known as the Patton Round House. Located next to a skeet range, the Army built the structure in 1938 as a hunting lodge and Officers Club annex. Patton spent a significant amount of time at the club and on the range. Interestingly, although other notable general officers such as Omar Bradley and Courtney Hodges frequented the lodge, the Army chose to name it after Patton. ${ }^{470}$

The Patton family house in which he lived until leaving for the Virginia Military Institute is also available for public viewing. Located at 1220 Patton Court just off Euston Road and Patton Way near the Huntington Library in San Marino, California, this

\footnotetext{
${ }^{468}$ Perry and Parke, vii.

${ }^{469}$ Photograph, U.S. Army Signal Corps, Patton Monuments: Image number P11-63, Photograph. At The General George Patton Museum.

${ }^{470}$ Unknown, "Historic House escapes demolition, rededication Friday,"

https://www.army.mil/article/50842/historic_house_escapes_demolition_rededication_friday.
} 
house is listed as a tourist spot, although it cannot be toured on the inside. ${ }^{471}$ Similarly, the Patton Homestead and Green Meadows Farm in Hamilton, Massachusetts is available for public viewing. Patton and Beatrice purchased the Essex County estate in 1928 to support their love of horses and fox hunting. Decorated with antiques and military artifacts collected during their wide travels, Green Meadows served as the Patton home until his death in 1945. Patton's son retired from the Army there in 1980 and started a pick-your-own blueberry business that evolved into an organic produce farm, the first of its kind in the area. After George Patton IV passed away in 2004, his wife Joanne established Green Meadows as an agricultural collective with fields named in honor of soldiers killed during the Vietnam War. Today, the farm cultivates medical cannabis that supports potential aid for chronic pain, depression, and PTSD symptoms endured by many American servicemen and women. Located at 656 Asbury Street, South Hamilton, MA 01982, 30 miles northeast of Boston, the homestead bills itself as continuing the Patton family legacy of supporting special-needs charities, the arts, the environment, schools, museums, and churches. In 2012, the Patton family gifted the homestead to the town of Hamilton. ${ }^{472}$

Other monuments marking the location of Patton's presence during his pre-World War II military service and are also visible to the public. A marker at Fort Meade, Maryland locates Patton's headquarters where he commanded the $304^{\text {th }}$ Tank Brigade from 1919-1920. At Fort Myer, Virginia, the Army renamed the Officer's Club as Patton Hall and repurposed it as an all-ranks club. Patton used the building as his headquarters

\footnotetext{
471 "Gen. Patton Pilgrimage Southern California," http://www.bargaintravelwest.com/California_Patton_Memorial_San_Gabriel.htm.

472 "Green Meadows Farm," www.gmfarm.com.
} 
from 1938 to 1940 . Hoping to make symbolic connections to the famous general, military officials on the post asserted, "Patton Hall symbolizes the changes, and the spirit of innovation, for which General Patton advocated during his career." ${ }^{473}$

The Church of Our Savior, an Episcopal church in San Gabriel, California, displays a stained-glass window that depicts Patton. Dedicated on October 13, 1946, the window pictures Patton in the lower right-hand corner mounted in a tank with an armored force patch on his left shoulder. The centerpiece of the window depicts Saint George on a horse, slaying a dragon whose scales carry Nazi swastikas. The insignia of the many divisions, corps, and the two armies he commanded also appear. A horse blanket depicts the insignia of the $4^{\text {th }}, 9^{\text {th }}, 11^{\text {th }}, 13^{\text {th }}, 14^{\text {th }}$, and $16^{\text {th }}$ Armored Divisions, all which served under Patton's command in Europe. Saint George's shield is emblazoned with the "A" of the Third Army shoulder sleeve insignia. In cloud formations below St. George appear the names of three major battles - Metz, Coblentz, and Bastogne. The cities of Rennes, Frankfort, Weimar, and Regensburg, which Patton's Third Army liberated, are shown being released from the clutch of the dragon's claw. Surrounding the window is a decorative border topped by the insignia of the four corps (the III, V, XII, and XX) under Patton's command during the final thrust into Germany. In the border are the insignia of the 12 divisions in his army. Bound together in a decorative treatment are the rivers that General Patton crossed in the German campaign: the Insi, Iser, Ems, Rhine, Somme, Danube, Saar, Kill, Sauer, Moselle, and the Meuse. Inscribed around the charger are the words from 2 Timothy 4-7: "I have fought the good fight. I have kept the faith. I have finished my course." The bottom bears the simple inscription: "In loving memory,

473 "Introducing Patton Hall," https://www.army.mil/article/174500/introducing_patton_hall. 
General George S. Patton, Jr. 1885-1945." window, which was adapted from needlepoint embroidery made by Patton's granddaughter. For a time, there was a non-profit organization called the George S. Patton, Jr. Memorial Center in San Gabriel. ${ }^{475}$

The War Assets Administration initiated a movement with the "friends, admirers, and associates of General Patton" to erect a monument to him "in recognition of his military achievements and his accomplishments as a man." A group of Patton's former staff officers created the George S. Patton, Jr. Memorial Association, chaired by Major General Robert M. Littlejohn, in order to raise funds. The association secured the services of J. E. Fraser, one of the most notable sculptors in the world at the time. The U.S. Military Academy granted permission to erect the monument there, which was finally dedicated on August 26, $1950 .{ }^{476}$ During the creation of the statue, while Fraser cast the hands, Beatrice threw in Patton's custom-made silver four-star rank insignia. The statue first stood outside the library, fifty yards away from a statue of General Eisenhower, and its reveal ceremony was well-attended with speeches made by Beatrice and noted historian Douglas Southall Freeman. Fittingly, the two statues face away from each other in an unwitting testament to the falling out the two long-time friends had at the end of World War II. ${ }^{477}$

\footnotetext{
${ }^{474}$ D'Este, 809.

${ }^{475}$ See printed folder: "General George S. Patton Jr. Memorial Center, San Gabriel, California," in Patton Archives (The General George Patton Museum, c1968). RBR Box A7-5, PATN 1986.32.05. Also see pamphlet, "The Stained Glass Windows of the Church of Our Savior," in Patton Archives (The General George Patton Museum).

${ }^{476}$ Letter, Littlejohn to Major General Harold W. Blakely, in Patton Archives (The General George Patton Museum, Jan 2, 1947).

${ }^{477}$ D'Este, 809.
} 
This was not the only statue cast and erected in the United States. In Boston stands a portrait statue of Patton, also designed by Fraser and installed in 1953 at the Charles River Esplanade along the Hatch Shell Circle - the location of Patton's speech during the bond drive tour in 1945. This eight-foot tall statue depicts a uniformed Patton raising a pair of binoculars to his eyes and rests on a four-foot pink granite base. There is another similar statue in Lacy Park in San Marino, California. Clearly, these two cities also wanted to link themselves to the famous war hero.

Since the early 1950's citizens of and visitors to Detroit, Michigan have been able to pass leisure time at the General George S. Patton Memorial Center, now called the George S. Patton Recreation Center. Situated in Patton Park, which contains Patton Pond, the 93-acre park in southwest Detroit once featured the first indoor-outdoor swimming pool in the United States. Queen Juliana of the Netherlands attended the opening ceremony as a gesture of thanks for the liberation of her country during World War II. ${ }^{478}$

There are many other places in the United States that bear the name Patton in honor of his service. These were further attempts to forever tie those places to the famous individual, whether or not there existed a direct link between the location and the man. In Patton Park at Hamilton, Massachusetts, there are concrete pillars gifted by the French government that originally marked the route Patton's Third Army took in its race across Europe in 1944 and 1945. At the Wisconsin Industrial School for Boys, a publically supported academy operated on a military-style organization, a group of students occupying one of the barracks decided to name their building after their hero and

\footnotetext{
478 "Patton Community Center," https://detroitmi.gov/departments/parks-recreation/community-recreationcenters/patton-community-center.
} 
placed metal plates bearing the name Patton on both entrances. ${ }^{479}$ Similarly, there is a George S. Patton Military Academy Junior Reserve Officer Training Corps (JROTC) program in Chicago.

At least five civilian schools and one school district bear the name Patton: The General George S. Patton School District in Riverdale, Illinois; the George S. Patton Elementary School in Garden Grove, California; the George S. Patton School in Riverdale, Illinois; Patton Junior High School at Fort Leavenworth, Kansas; General Patton Elementary School in Dýšina, Czech Republic; and The George S. Patton High School in Harbor City, California. School sports teams in Hamilton, Massachusetts have the mascot of "Generals" in honor of Patton. Motorists can drive on General Patton Avenue, General Patton Boulevard, Patton Court, Patton Street, Patton Lane, General George Patton Drive, George Patton Drive, George Patton Lane, General George Patton Road, General Patton Street, George Patton Street, Patton Way, or Patton Boulevard in at least 25 towns and cities across the United States. ${ }^{480}$ What is telling about the vast popularity of Patton is that he never set a foot in most of the places that now have roads named in his honor.

There are two museums in the United States (and two in Europe) named after Patton. Most notable is the U.S. Army’s General George Patton Museum at Fort Knox, Kentucky. A short drive away, visitors can purchase a General Patton hamburger at the

\footnotetext{
${ }^{479}$ Letter, T.R. Uthus Letter, October 12, 1944. The George S. Patton Papers (Library of Congress), Fan Mail Box 41, folder 1.

${ }^{480}$ This list of motorways may not be exhaustive. A map search shows these particular roads and highways in Shreveport, Louisiana; Mandeville, Louisiana; Murfreesboro, Tennessee; San Marino, California, Houston, Texas; Closter, New Jersey; Springfield, Illinois; Franklin and Nashville, Tennessee; Brentwood, Tennessee; Des Plaines and Chicago, Illinois; San Antonio and El Paso, Texas; Hammond, Lake Charles, and Morgan City, Louisiana; Jackson and Pascagoula, Mississippi; Orangeburg, South Carolina; San Marino, California; Wyndmoor, Pennsylvania, and Moses Lake, Washington.
} 
Back Street Café in nearby Muldraugh, Kentucky. Fort Knox’s Patton Museum opened in 1948 and immediately attracted as many as 1,200 visitors in a single day. ${ }^{481}$ Visitors to the General George S. Patton Memorial Museum, located at the site of the Desert Training Center in Chiriaco Summit, California, can view a ten-foot tall statue of Patton that is visible from Interstate 10. Patton is particularly popular in California. A Golden Palm Star was dedicated in 2016 in Patton's honor on the Walk of Stars in Palm Springs. Besides President Eisenhower, Patton was the only military figure to be recognized on the walk. ${ }^{482}$

Many military installations have features with Patton as a namesake. At Fort Shafter, Hawaii, there is a plaque memorializing "Patton Gate." There was a Patton Hall at Fort McPherson, Georgia until the current headquarters of Third Army, which carries the motto, "Patton's Own," moved into a new Patton Hall at Shaw Air Force Base, South Carolina in 2011. As noted previously, Patton Hall at Fort Riley, Kansas has a large plaque placed in the entryway. At the dedication, Major General ID White, Kansas Governor Andrew Schoeppel, General Jacob Devers (the Commander of Army Ground Forces), and Secretary of War Robert Patterson joined Beatrice in delivering speeches to the crowd. Children are able to attend the aforementioned Patton Junior High School at Fort Leavenworth, Kansas or play in Patton Park at Fort Hood, Texas. Every day, people drive on Patton Road to the Army's rocket and missile programs at Redstone Arsenal, Alabama or on Patton Drive on the way to the Patton Hall Officer's Club at Fort Myer, Virginia. One weekend a month, Army reservists drive to the General George S. Patton Army Reserve Center in Bell, California. Patton's influence within the Department of

\footnotetext{
${ }^{481}$ George S. Patton and Martin Blumenson, The Patton Papers (Boston: Houghton Mifflin, 1974), 4.
}

482 "Palm Springs Walk of Stars," www.palmsprings.com/walk-of-stars/. 
Defense extends beyond the Army. The 2005 class at the Air Force Academy named Patton their class exemplar, the only non-military aviator (although he did earn a private pilot license) to receive the honor.

Officials at Fort Benning, Georgia, where Patton spent several months with the $2 \mathrm{~d}$ Armored Division prior to World War II, named several post features after Patton. Soldiers fire machine guns on Patton Range, play golf at Patton Golf Course, and soldiers and their families live in the Patton Village residential area and play in nearby Patton Park. The $316^{\text {th }}$ Cavalry Brigade's General Instruction Building, Patton Hall, was "named after one of the U.S. military's most famous figures. The 15 million dollar building houses 48 classrooms and a 230 -seat auditorium where new lieutenants, captains, and senior sergeants are trained in the art of mounted maneuver warfare." In 2005, the Armor School moved from Fort Knox to Fort Benning. Wanting to maintain the branch's heritage, many of the buildings dedicated on the post "are named for the same heroes of Armor and Cavalry that we grew to love at Fort Knox. None of those buildings at Fort Knox [except for the Patton Museum], though, was named after the man who perhaps made the greatest impact on the modern Armor branch." ${ }^{" 43}$

Awards are yet another way in which Patton was memorialized. For example, Norwich University awards the Patton trophy, an engraved pistol, to the best cadet who elects to serve in the Armor branch in order to keep alive "the memory of one of the finest soldiers that America produced." ${ }^{484}$ In the Civilian Marksmanship Program National Trophy Pistol Match, the General Patton Trophy is awarded to the top pistol

\footnotetext{
483 "Heart of Armor School named for Army legend," https://www.army.mil/article/79550/heart_of_armor_school_named_for_army_legend.

${ }^{484}$ Letter, Major General E. N. Harmon to Lieutenant Colonel George S. Patton, November 3, 1964.
} 
shot. ${ }^{485}$ Additionally, at the end of every training cycle at the U.S. Army Command and General Staff Officer Course, the General George S. Patton, Jr. Award for the

Distinguished Master Tactician is awarded to the student most proficient in military tactics.

Americans memorialized and commemorated Patton widely in the United States in various forms of public memory. However, the extent to which Patton appears in monuments, ceremonies, and place names in the U.S. is rivaled by several countries in Europe, where Patton's fame is on par with that of his home country. The editor of Army magazine, John B. Spore, wrote that everywhere he went in Europe he followed the footsteps of Patton, public records that reminded Europeans daily of the travails of Patton and his Third Army during the liberation of several countries and hundreds of towns and villages. Spore recalled that he went to places where Patton had his headquarters, places where he slept, and so on, even in Germany, the country Patton helped conquer. For example, Spore recalled a Patton Hotel in Garmisch Germany. Patton, he wrote, was as much a legend today as Stonewall Jackson was in 1870 for Americans or Napoleon or Frederick the Great was for Europeans. ${ }^{486}$ As Patton's nephew wrote:

The luster in Europe of the Patton name is not a surprising thing, but it is something to think upon. I have often found it true that on meeting many people on the Continent, the General's memory is revered by allies and those whose lands he freed. He is spoken of with admiration even by former enemies whose troops he crushed. Sometimes it has seemed that he was more appreciated abroad than in his own country. All the way from Normandy and Cotentin peninsulas, southeast to Paris and on toward the west bank of the Rhine, are concrete mileage markers carrying the inscription 'Route de la glorieuse 3me Armee Americaine,' and it is called 'la route de la liberation' since that is what it was. And on the Patton grave at Hamm, the Luxembourgers, even in winter, still daily place fresh flowers. ${ }^{487}$

\footnotetext{
485 "Army defends Best in Nation title at National Trophy Pistol Matches," https://www.army.mil/article/152918/

${ }^{486}$ Patton and Blumenson, The Patton Papers, 3-4.

${ }^{487}$ Ayer, 225-26.
} 
As in the United States, evidence of a public memory of Patton in Europe is undeniably visible, even in locations where he never operated, such as an avenue named the Generaal Pattonlaan in Eindhoven, Netherlands. However, all public memory sites related to Patton are situated in places he touched, both physically and metaphysically. All along the route of Patton's World War II journey in Europe, markers and memorials remind Europeans and tourists of the impact Patton had not just on the war, but on European public and collective memory.

Peover Hall in Knutsford England was the location of Patton's Third Army headquarters where he prepared his troops for combat on the mainland. Since 1944, an American flag that Patton donated remains posted in the chapel where, visitors are told, "General Patton and his chief of Staff Officers attended morning service here regularly for about six months whilst Peover Hall was his Headquarters. It was the $3^{\text {rd }}$ Army by its 'right hook' compelled the Germans to draw into Flanders in 1944." A bronze plaque tells pilgrims to the estate, "This flag is placed here to commemorate the fact that the commanding general and his staff and members of the American $3^{\text {rd }}$ Army worshipped here during the Second World War 1944.” Although Peover Hall is a five-hour drive from major tourist sites in London, people from around the world, including New Zealand, Canada, England, France, and the U.S., visited the site. One family from Richmond, Virginia made the trip and wrote in the guest book "God Bless our world. Thank you General Patton and our friends in England." Others came from Utah, Massachusetts, Illinois, Oregon, Nebraska, California, and North Dakota. A nearby culde-sac is named Patton Close. A local public house named the Whipping Stocks Inn where Patton ate lunch daily memorialized the seat where he sat. Before leaving for 
battlefields in France, Patton paid for flowers to be placed on his table for an entire year after he left England, a tradition the inn still honors today. Above the table are pictures of him with captions explaining Patton's local connection. One caption reads, "Pistol packing Patton setting off to walk his dog in Knutsford. He was so named because of the pair of pearl [sic] handled pistols he invariably wore. Patton has become a household name in Knutsford since the film Patton collected many Oscars and was filmed in and around Knutsford." Another caption reminds those who enjoy the pub's libations,

General George Smith Patton, famous general and tank commander who was stationed at nearby Peover Hall for a while in the Second World War...made the Whipping Stocks his 'local' where he and his officers could relax. He made and enforced two rules, firstly all GIs were banned from his pub and secondly the table he always sat at had to have flowers on it. When Patton left for Normandy, what had become tradition carried on in his absence as he left a year's subscription with the local florist to decorate his table with flowers, the table you are now sitting at!!!

In an apple orchard near Nehou, France there is a Patton's Third Army Memorial Park with an obelisk that marks the location of Patton's first headquarters after arriving on the continent after the D-Day invasion. From there spreading across Europe are traces of Patton memorialization. ${ }^{488}$ Beginning at Utah Beach where Patton first stepped onto the continent during the Second World War are painted concrete road markers along the Voi de la Liberté (Liberty Road) that identify the route taken by Patton's Third Army from Normandy to Bastogne, Belgium. Since 1947 with the opening of Liberty Road, drivers using a dedicated souvenir map pass by these monuments every 1,000 meters through France, Luxembourg, and Belgium.

488 "Army defends Best in Nation title at National Trophy Pistol Matches"; "Memorial "Camp Patton" Nehou," https://www.tracesofwar.com/sights/20790/Memorial-Camp-Patton-Nehou.htm. The Living Flame Memorial Center in Nehou, Normandy marks the site from which Patton launched his advance across France in 1944. It is located in the apple orchard where he placed his headquarters when he first arrived on mainland Europe. 
Towns and cities that Patton and his Third Army liberated honored him in various ways. Avranches, France named a common area Patton Square that contains a Patton Memorial. At least ten communities have a Place du Général Patton, including Avranches, Thionville, Troyes, and Le Mans, towns affected by Patton's push out of the Normandy hedgerows. Next to the Avenue de la Grande Armée in Paris is a Place du Général Patton. Automobiles crossing France pass daily along Rue Patton in Seine-Port, Avenue du General Patton in Melun and Maxéville, Rue de l'Armeé Patton in Nancy, Rue du Général Patton in Lorraine and Châteaubriant, and Général-George-S-Patton [avenue] in Rennes. A plaque in the Hotel de Ville in Etain, France commemorates "General Patton, Liberator of the City." 489 On November 26, 1950 Mayor Jean Robert memorialized an avenue "in homage to the liberator of Saint-Avold." Avenue du General Patton leads to a U.S. military gravesite in the city. Patton, "the unforgettable name of its liberator," was a local hero and the city promised to "always mention in the pious workshop of its heroes who rest among us the memory of the one who led them to Victory and Immortality." ${ }^{490}$

A plaque recognized Patton as an honorary citizen and liberator of the city of Etain, France. The city center of Avranches, France was adorned with a Patton Memorial and bust statue. ${ }^{491}$ The Patton monument in Arlon, inaugurated in 1957, commemorated the spot on which he made a speech to his men as they advanced on Bastogne during the Battle of the Bulge in December 1944. ${ }^{492}$ Veterans of Foreign Wars Benjamin Franklin

\footnotetext{
${ }^{489}$ Photograph, "Patton Plaque," in The George S. Patton Papers (Library of Congress).

${ }^{490}$ See undated dedication manuscript and Letter, Jean Robert to Mrs. George Patton, May 4, 1951 in Patton Archives (The General George Patton Museum).

491 "A Bust of General Patton at the Patton Memorial, Avranches, Normandy, France,"

https://www.alamy.com/stock-photo-a-bust-of-general-patton-at-the-patton-memorial-avranchesnormandy-11849887.html.

492 "Monument to General Patton," https://aomda.org/en/content/monument-general-patton-arlon.
} 
Post in Paris, France commemorated the $25^{\text {th }}$ anniversary of the victory in Europe with a plaque that included Patton, the only American noted.

As in France, Belgium also has several markers of public memory that add to the collective memory of Patton. For example, both Ixelles and Brussels, Belgium have a Rue du Général Patton. A Patton memorial in Bastogne, Belgium, the town in which elements of Patton's Third Army relieved the surrounded and besieged $101^{\text {st }}$ Airborne Division during the Battle of the Bulge in December 1944, rests at the end of the Place du Général Patton. In a small museum in Bastogne, visitors view Patton artifacts, particularly one of his Brigadier General stars, his Arcturus sweater (Patton named his yacht the Arcturus and his entire family wore customized blue sweaters with the name of the yacht stitched to the front) and whistle he wore during his yacht trip from California to Hawaii in May 1935. Available for viewing is his riding crop, along with a series of his quotes. In gift shops all over the town, shoppers are able to purchase Patton souvenirs such as books, coffee mugs, and other collectables adorned with his image. Local dining establishments display his picture. It is difficult to go far in Bastogne without being reminded of Patton's importance to the community: clearly, he remains an asset to the tourism industry there.

Even in Germany, Patton memorialization abounds. Not exactly the autobahn, travelers motor (more slowly) along General-Patton-Straße in Bad Tölz, Germany. Pattonville near Ludwigsburg, a former U.S. military installation that is now a civilian neighborhood, bears his name. For decades there was a plaque in a Heidelberg hospital memorializing the place in which Patton "departed this life in this room on 21 December 1945" before the Army finally tore the structure down. The Heidelberg Health Center in 
Germany held an annual remembrance ceremony for General Patton from his death until shortly before the center closed in 2013. The final ceremony took place on November 9 , 2011. The commemorations purportedly served as a way to honor his life rather than his death, a remembrance ceremony rather than a memorial service. One soldier noted that, "the importance of the Patton ceremony is to remember our important leaders and what they accomplished. The progress we have made over the years is all due to these leaders. It is important to remember where, how, and the people who assisted the progression of the United States Army to where we are today." ${ }^{, 493}$

Echoes of Patton remain on other U.S. military installations in Germany as well, such as the Patton Fireside Lounge, Patton Gate, and Patton Barracks at Grafenwoehr, Germany. Additionally, in Heidelberg there is a Patton Barracks and Patton Fitness Center. On March 25, 2017 German and U.S. soldiers and dignitaries conducted a ceremony to memorialize the historic first Rhine River crossing of World War II by Patton's troops. "Although an action of war, this historic moment was memorialized as a symbol of the bonds of two nations, then enemies, now steadfast allies." The event brought together "the German and American communities and this crossing was really the beginning of democratic Germany, after the Nazi regime was defeated." In a grand gesture, the granddaughters of both Patton and Rommel attended the commemoration. ${ }^{494}$ Perhaps nowhere is there a larger concentration of public memory sites dedicated to Patton than in Luxembourg, the final resting place of General Patton. The impact of his burial site in the Luxembourg American Cemetery and Memorial at Hamm, three

\footnotetext{
493 "Health Center Holds Final Patton Remembrance Ceremony," (November 9, 2011), https://www.army.mil/article/69466/.

494 "Rhine Crossing Memorial Builds Metaphoric Bridge,"

https://www.army.mil/article/184917/rhine_crossing_memorial_builds_metaphoric_bridge.
} 
miles from Luxembourg City, cannot be overstated. As Richard Stillman, a former

Lieutenant Colonel and G-3 operations officer in Patton's headquarters put it:

Visitor traffic in the years 1946-47 was impressive. On one particular Sunday, our guides actually counted some-what more than 14,600 persons entering the grounds. As virtually every visitor wished to see General Patton's grave, it was impossible to maintain a lawn on the adjacent graves. By the end of a Sunday, visitors would have trod a rut six inches deep from the path to the grave, necessitating a re-sodding job in the morning. At our repeated urging, therefore, we were authorized to transfer the grave from a plot in the west end of the grounds to its present location. The transfer was affected on 19 March 1947. Prior to the transfer, the authorities had wanted the grave to be moved to the west end of Row 1, Plot B. An unknown grave was placed at the east end of the row to establish architectural equilibrium. We maintained that this was no solution, as large tourist groups insisted on being photographed around General Patton's cross, and the nearby graves would still be disturbed. The Plot B idea was thus abandoned, but this interim plan explains the presence of the unknown in Plot B, Row 1, Grave 2. ${ }^{495}$

Before his death in 1985, Stillman requested to be buried in Arlington National

Cemetery. He was fittingly buried along Patton Drive, overlooking the Pentagon. ${ }^{496}$

Patton's current resting place is at the head of the formation of white crosses and

Stars of David with a concrete sidewalk leading to it, alongside the graves of the men killed during Patton's greatest hour, the Battle of the Bulge. In the cemetery welcome center, a portrait of Patton and a short description of his career and manner of death greet visitors, describing him as "One of America's greatest WWII generals," a mild understatement. People from all over the world leave comments in a guest book, such as one New Zealander who simply wrote, "AMAZING - Patton - great," and an Englishman who succinctly noted, “Great General Patton.” A Texan added, "Dad was in Patton's $3^{\text {rd }}$ Army." A Chilean family offered the pellucid statement, "Honor and Glory to Patton." A Florida family came to "Honor G. Patton" and another offered the oft-heard personal connection, "My Dad served under Patton." A California native and U.S. Air Force veteran living in Sweden wrote, "Gen. Patton is a personal hero of mine." A family from

\footnotetext{
${ }^{495}$ Richard J. Stillman, General Patton's Secret Missions (New Orleans, Louisiana: R. J. Stillmlan Co., 2005), 98-99.

${ }^{496}$ Ibid., 115.
} 
England offered a heartfelt, "Thank you America. The Lord will watch over your grave General Patton! And your proud men. All rest in peace for now and forever. Enjoy your afterlife!"

Patton's grandson wrote: “"His burial at Hamm with hundreds of his men served to transcend the egotistical bluster that had distanced him from the common soldiers. It made him one of them. A casualty of war. Another dead American son....' George S. Patton's legacy is that he will lie for eternity in the midst of men who died in what he regarded as a noble calling. Were we able to ask him, Patton would undoubtedly proclaim: 'I'm damn glad to be here." ${ }^{\prime 497}$ Circling the cemetery is the Boulevard General George S. Patton and the Rue du Général Patton in nearby Luxembourg City, where pedestrians can read a plaque commemorating Patton and the expulsion of the German army from the city.

In the Czech Republic, a nation eternally grateful for Patton's attempt to liberate it not only from Nazi overlords but also from the inevitable takeover by Soviet communists immediately following World War II, evidence of a public memory is acutely visible, particularly in Pilsen. There is a General Patton Bridge over the river Mže located near the Patton Memorial Pilsen Museum, opened in 1990, and a General Patton Elementary School in Dýšina, which also boasts a statue of Patton in the same town, commemorating the $60^{\text {th }}$ anniversary of the liberation of Czechoslovakia. Similarly, in Sweden it is possible to stroll through Patton's Hage, a meadow in Uppsala. During Patton's visit to Sweden in 1945 he and Prince Gustav Adolf were guests during a military exercise in the area and afterwards gathered in the meadow now named after him. To further honor the

${ }^{497}$ D'Este, 804. 
American hero in Sweden, on Feb 23, 2017 the Union Internationale de Pentathlon Moderne Hall of Fame inducted Patton for his participation in the 1912 Olympiad in Stockholm. ${ }^{498}$

Several other public memory sites commemorate Patton's presence in Europe prior to World War II, illustrating the longevity of Patton's popularity there. In the small village of Bourg, France, one local citizen whose home is near the Rue du General Patton spelled "Patton" in their front yard with large white stones. The road named after Patton leads to the site where he trained his tankers for combat during World War I. On the outskirts of Bourg rests a Tank Corps and Patton Memorial. The original plan for the memorial included a playground and plaque to Patton and both exist there today. Dedicated in 1973 and initiated by 115 of Bourg's residents, these French citizens erected the monument to preserve the memory of Patton who "greatly contributed to the liberation of France during the last two wars and particularly in our region." Furthermore, "As a sign of recognition and of the faithfulness of an old friend of our country, it has been decided that on the $25^{\text {th }}$ anniversary of his death to erect a monument to him by public subscription. This monument will be placed on the former training ground of the tanks, 6 kilometers south of Langres bordering on the well-traveled, international route R.N.67." 499

A plaque at the Saumur French Cavalry School where Patton studied swordsmanship after the 1912 Olympic Games in Stockholm reminds French cavalrymen

\footnotetext{
498 "Patton Receives Union Internationale de Pentathlon Moderne HOF Induction," https://www.army.mil/article/185645/.

${ }^{499}$ Letter, Thomas McNulty, World Wars Tank Corps Association, in Patton Archives (The General George Patton Museum, October 20, 1972); Francois de Vaux Letter, Mayor of Langres, France, ibid. (September 6, 1972).
} 
daily that the famous American once trained there. If they needed further reminding, the school also has a Patton Hall at the campus's Saumur Armour Museum, a military hanger on loan from the French Armoured Corps and Cavalry School once used as a tank restoration building. It seems Patton's untimely death spurred many of these memorialization efforts soon after the end of World War II. Two of these particular plaques "on the school where he studied and on the hotel where he and Mrs. Patton stayed" were visible by the early 1950 s. $^{500}$

As noted earlier, the care to which countries and various communities construct and tend to memory markers, particularly in the form of memorials, monuments, and statues, demonstrates a shared recognition and commitment to giving links to the past, i.e. collective memory, a sense of permanency. Often, these sites reach a sacred status and allow for the enactment of rituals, commemorations, and remembrances that symbolize that commitment. These markers frame what and how people remember, often through the use of symbolism. Additionally, these forms of public memory stimulate historical memory (as opposed to biographical memory, those memories of personal experiences) and allow for the recreation of a collective interpretation of the past. Ceremonies assist in the recollection of great actors and events in history and help hold communities together. Collective memory both shapes and is strengthened by those events.

On April 4, 1946, Robert P. Patterson, U.S. Secretary of War, spoke at the dedication of Patton Hall at Fort Riley, Kansas. "No more fitting place for a memorial to General George S. Patton could be chosen than here at the Cavalry School at Fort Riley, Kansas. For George Patton, the soldier, was first and last a cavalryman, steeped in the

\footnotetext{
${ }^{500}$ Semmes, 26.
} 
traditions of the Cavalry. It is only right that his memory should be honored here. He himself would consider this dedication a worthy tribute to any man." The memorial attempted to enshrine the memory of Patton as one of the greatest American soldiers for generations to come. The lessons to be learned from him were an "unswerving will to master his profession, an unsparing devotion to duty, and unshakable trust in those who served with him.” Meant to inspire cavalrymen undergoing training at Fort Riley, Patton Hall reminded these young men of their heritage and made a direct connection between them and the famous general for decades. U.S. Congressmen Albert M. Cole and Frank Carlson attended the dedication as well as the Army Chief of Staff, Chief of Army Air Forces, Chief of Army Ground Forces, and Chief of Army Service Forces. Although unable to attend, the President of the United States and former Prime Minister Winston Churchill were formally invited, lending evidence to the high profile nature of the ceremony and the memory marker. The bronze plaque with a bas relief of Patton's face remains in the lobby to this day. ${ }^{501}$

The Fort Riley example of the enactment of public and collective memory was a commemoration, defined in this study as an active form of remembering together. Joint recollection does not require individual experiential knowledge in order for groups to commemorate a memory. It is the practice of representation through a type of ritual or rite and gives substance to the discourse of collective memory. ${ }^{502}$ As sociologist Maurice Halbwachs recognized, historical memory can only be stimulated in indirect ways through reading, listening, or participation in commemorations and festive occasions when people gather together to remember the deeds and accomplishments of long-

\footnotetext{
${ }^{501}$ See pamphlet, "Patton Hall Dedication," in Patton Archives (The General George Patton Museum). ${ }^{502}$ Gillis, 186.
} 
departed members of the group. In this case, the past was stored and interpreted by a particular institution. The present generation becomes conscious of itself by counterpoising its present to its own construction of the past. Through participation in commemorative meetings with group members of the current generation people recreate a past through their imagination that would otherwise slowly disappear with time. The void between periods of effervescence and ordinary life are filled by collective memory. Ceremonies help the recollection of great events of the past and hold the community together by serving as a focal point of a shared sense of identity. ${ }^{503}$

Several other commemorations of the type Halbwachs described took place in the United States after Patton's death. For example, setting aside his part in the battle over post-war legacies for a brief interlude, President Dwight Eisenhower wrote to Major General J. H. Collier, Commanding General of the Armored Center at Fort Knox on November 9, 1953, two days before Armistice Day (and Patton's birthday), to recognize the importance of Patton's military service. "On this Armistice Day, set aside by the Nation for reverent tribute to those who gave their lives in the American cause, it seems particularly fitting that the Armored Forces should honor the memory of General George S. Patton, Jr. He was a masterful battle leader; a leader characterized by the indispensable qualities of patriotic loyalty and soldierly courage. With you, I join in a salute to my friend of a lifetime and to the Forces he led during World War II." 504

Days later on November 11, 1953, a year before the renaming of Armistice Day as Veterans Day, there was a ceremony at Fort Knox that coincided with the release of a

\footnotetext{
${ }^{503}$ Halbwachs, 23-25.

${ }^{504}$ Letter, Dwight D. Eisenhower to MG J. H. Collier, in Patton Archives (The General George Patton Museum, November 9, 1953).
} 
commemorative stamp collection dedicated to the late hero of the U.S. Armored Forces. The U.S. Postal Service created a special postage stamp, which sold out that day at the Fort Knox Post Office. The ceremony included a speech by retired General Jacob Devers, a contemporary peer of Patton's and later the Commanding General of Army Ground Forces. The Fort Knox-based Inside the Turret newspaper issued a commemorative stamp paper that included several articles about Patton. ${ }^{505}$ The post office in Patton, Pennsylvania, the only town so called in the states, received thousands of envelopes with one of the stamps attached from people asking for a postmark. ${ }^{506}$

Some commemorations were seemingly picayune in the moment but later served to embed Patton's memory in perpetuity. Remarks by Delaware Senator J. Caleb Boggs at a Senate breakfast group on May 22, 1963 during the observance of Armed Forces Day solidified the Patton legend in the official Congressional Record. His remarks also serve as an example of the malleable nature of collective memory, as he used it to address current issues. "We are living in dangerous times of conflict and revolution and of exciting new adventure.... I thought we might find some encouragement in the spiritual experience of an unusual man best known as a hot war battle leader." Boggs referred to the famous Patton prayer and lines from Patton's poem "God of Battles," seemingly with the intent for the message to convey that they should look to God and religion as Patton did when dealing with contemporary issues, namely the burgeoning hot war in Vietnam and the Cold War writ large..$^{507}$

\footnotetext{
505 "Untitled," Inside the Turret November 11, 1953.

506 Patton and Blumenson, The Patton Papers, 841.

${ }^{507}$ United States Congress, "Official Congressional Record," ed. U.S. Congress (May 22, 1963).
} 
Like the unveiling of monuments and statues, commemorative events also spanned the course of time. On Memorial Day, 2014 people gathered for a commemoration ceremony and screening of the movie Patton in Charlottesville, North Carolina as a means to collectively and publicly remember the war hero. ${ }^{508}$ On February 23, 2017, after the Union Internationale de Pentathlon Moderne Hall of Fame inducted Patton (the lone American to compete in the inaugural Olympic Modern Pentathlon in 1912 in Stockholm, Sweden), the U.S. Army released a statement about the inauguration. The Army asserted that nearly 105 years after Patton's participation in the event, and "half a century after leading U.S. troops through World Wars I and II, one of the Army's greatest military leaders continues to inspire Soldiers." Patton "motivated many young officers to compete and train in pentathlon" in subsequent generations. As one 2012 participant described, Patton was "the first [American] athlete to compete in pentathlon in the Olympics and he was a Soldier in the Army. I was a Soldier in the Army, so that was a neat feeling and quite an honor to still be involved in the sport to see Gen. Patton get inducted to the hall of fame." Another stated, "it's such a cool legacy to follow. I hope I can have a footprint on history, too." Others made personal connections to Patton at the ceremony, including the officer who accepted the award on behalf of Patton, who stated, "It's also an honor for me to accept this award because General Patton was an armored cavalry officer, of which I am...." ${ }^{n 09}$ Commemorations such as this not only allowed for a collective and public remembrance but also allowed for the creation of personal connections to Patton.

\footnotetext{
${ }^{508}$ Ryan M. Kelly, "Memorial Day Commemoration, "Patton" Screening," http://www.dailyprogress.com/news/local/memorial-day-commemoration-pattonscreening/collection_2db32d6c-e44d-11e3-a430-001a4bcf6878.html.

${ }^{509}$ Tim Hipps, "Hall of Fame Inductee Patton Still Inspires Soldiers," http://www.army.mil/article/183681.
} 
Reminiscence is a primary prop of public memory as well. Individuals do reminisce when thinking nostalgically of the past, but when collective or public memories are discussed between individuals, those memories also likely become manifest as reminiscences. Remembering as an act, such as during visits to museums or memorials, comes with social and collective aspects. It typically occurs as social memory, those shared memories between people who already have a relation to one another. ${ }^{510}$ Yet collective memory need not reside within individuals who have some previous relation, although it often does, and could serve as the only relation between individuals. This idea is salient for the latter part of the study when the focus begins to narrow on a certain collective. Social memories are not necessarily public except when enacted in the public sphere for broader consumption. Conversely, collective memory is a process that is done neither individually in isolation from others nor in the company of others with whom one is acquainted, and is a form of remembering that has no base in overlapping historicity or shared places but is brought together by a conjoint remembrance of a certain event or person, no matter where those who remember are located or how unrelated they are to each other. Collective memory also does not have to occur at the same time. All that matters is commonality of content - that which is shared is collective memory. Whereas social memory derives from a basis in a shared experience, history or place, collective memory has no such basis but is distributed in the minds of a population, and illustrated in public memory settings such as memorials, monuments, and museums. As such, the aggregate of public memory places dedicated to Patton constitute part of his collective memory. Collective memory then is the sum of the

${ }^{510}$ Phillips, 21-22. 
parts of individual, social, and public memory projects. ${ }^{511}$ If memory is thought of as a concentric circle diagram, individual memory is the inner circle, social memory is the next circle, public memory the next, and collective memory is the outer ring. ${ }^{512}$

Temporary exhibitions also provided visitors opportunities for reminiscences of Patton and the victorious era he represented. One show opened as early as June 1947 at the First National Bank of Boston that included Patton's medals and citations, reminding viewers that "New England's great and gallant soldier will never be forgotten by the American people, whom he served so well, or by the freedom-loving people of other lands whom he helped to liberate from tyranny."513 Exhibits on Patton were not confined to the years immediately after his death. An exhibit titled "Forward Knight: George S. Patton, Jr., Boy Dreamer to Military Legend" purported that it "reveals another side of Patton." Opening in 2004 at the Wenham Museum in Massachusetts, the exhibit's curator, Tracey deJong, wanted the exhibit to "let Patton speak for himself as much as he can." Illustrating aspects of Patton's life hitherto not covered by many biographers and historians, the exhibit included toys Patton played with as a child, footlockers from World War II, the wedding dress worn by his wife, and home footage of a sailing trip to Hawaii. If the public needed prodding to see the exhibition, the curator asserted, "Anyone who doesn't know about him should.",514

Unlike books, memory projects in the public sphere are quite unique within the general area of production of collective memory. They are almost always collective

\footnotetext{
511 Ibid., 23.

512 Ibid., 25.

513 See exhibition pamphlet by the First National Bank of Boston, in Exhibitions Folder, "General George S. Patton's Medals and Citations," in Patton Archives (The General George Patton Museum, 1947). 514 "Exhibit Reveals Another Side of General," The Eagle Tribune April 24, 2004.
} 
endeavors, involving various types of intermediary work, such as marketing and distribution. There are opinion makers, critiques, and educators who offer interpretations, all before an intended audience "reads" it. Who wins the narrative battle, and why, is germane to memory studies. ${ }^{515}$ Public memory, like collective memory, is a system of beliefs and views produced from a political discussion that involves the fundamental issues relating to the entire existence of a society: its organization, structure of power, and the very meaning of its past and present. Rooted in the need to interpret reality and connect the past with the present, the ideas and symbols of public memory attempt to mediate the contradictions of a social system. This requires the use of symbols, beliefs, and stories that people can use to make connections. Beliefs and ideas about the past help a collective understand both its past, present, and future. ${ }^{516}$ Public memory also welcomes participation from ordinary people and not specifically on the private level. Public support is required, including funding and rules governing public discourse and public space. Individual work and initiative can carry a project in its initial stages, but not without some institutional backup, such as the Army or Federal Government. Otherwise it would be a small circle of those directly involved. Sponsorship brings an element of influence to the table. Initiators must justify their existence to supporters and the public. Political loyalties, commercial considerations, and desires to appeal to a wider audience results in effective self-censorship on the part of memory workers. ${ }^{517}$

\footnotetext{
515 Irwin-Zarecka, 176.

516 Gillis, 75-76.

${ }^{517}$ Irwin-Zarecka, 139.
} 
Remembrance cannot be taken for granted and to understand the rationales for it the testimony of memory workers' actions, or what they justified as the reasons for remembrance, is of paramount importance. The major focus of the cognitive and communicative process of public memory is not about the past, per se, but about matters in the present. For instance, the movie Patton was more about 1970 than it was about 1944. Like collective memory, public memory cannot be measured as ethical in terms of how true or authoritative they are, but rather on the quality of the social relationships established or sustained through their expression. ${ }^{518}$ This sheds light on the wider societal dynamics of remembrance. The message as intended may be received and internalized by an immediate constituency, but there may also be a multiplicity of interpretations. While the developments of public memory projects are best studied as they occurred in order to understand the framing process, unfortunately this is not possible for most forms of Patton's public memory already in existence. ${ }^{519}$ Records of what the initial motivations were hardly exist. However, that these public forms of memory remain is still important. Tracing the evolution of the changing messages is possible, however, as has been demonstrated so far and in subsequent chapters.

Public memory does have different priorities during different eras but follows the lines of collective memory. Public memories include those collective memories that take tangible form in the public sphere, and although the form may be static, such as a monument, the memory encapsulated in it is not. These are visible indications that humans care deeply about their past because human nature has a deep and profound desire for heroes with symbolic meaning that foster social solidarity. The struggles over

\footnotetext{
518 Phillips, 205.

${ }^{519}$ Irwin-Zarecka, 140-41.
} 
memory may be viewed as a reflection of current issues and priorities in which history serves as a convenient substitute or battleground for fighting contemporary ideological battles. Battles over the past are rarely about the past itself - current matters frame how much people care and what it is they care about. One only needs to look at contemporary debates over Confederate Civil War monuments to understand the social and political storm caused over public memory. There are two forces that impact the vicissitudes of remembrance; first that of allowing, supporting and encouraging the construction and maintenance of a morally purified narrative, and second when pressure places demands to engage in full moral accounting for the past. Politics and social concerns both carry with them the risk of sanitizing the record for the sake of expediency. There are parallels between particular and universal concerns, but at issue is the task of persuading the majority, and especially the socially powerful, that a restructuring of collective memory should take place. ${ }^{520}$ Nor does the past, no matter how long ago, become neutral over time. Caring about the past requires investment in memory - intellectually, emotionally, and pragmatically. If that collective memory is not attended to periodically, the public forms of that memory risk becoming hijacked by opposing political, ideological, individual, or other organizational forces. ${ }^{521}$

Who were the stakeholders in the various forms of public memory relating to Patton? The expressed intent of those keeping the memory of Patton alive was universally altruistic on the surface. Certainly there was a range of something to gain politically, economically, ideologically, or financially, although those reasons can only be speculated. Authors and publishers sold books, dark tourism sites such as battlefields and

\footnotetext{
${ }^{520}$ Ibid., 134-36.

${ }^{521}$ Ibid., 74-77, 83, 128-29.
} 
cemeteries (which are generally regarded as the most-visited tourism sites in the world) drew crowds of people who engaged in meaning-making processes, monuments and memorials served as civilizing centerpieces for communities, family members wanted their most famous member to remain relevant, and politicians hoped to gain attention and influence. D'Este claimed that Beatrice, who was “Patton's most articulate and passionate benefactor," traveled widely with the explicit intent "to perpetuate his memory." Beatrice certainly played a role in keeping her late husband's memory alive for a myriad of reasons, but most were personal.

Several non-profit organizations also attach the Patton name to projects designed to enhance the quality of life of patrons, serving as an example of good intentions, at least on the surface. For example, the Patton Veterans Project has a mission "to help veterans cope with posttraumatic stress, reduce social isolation, and strengthen family, community, and professional bonds" through filmmaking workshops that help them process their service experiences. ${ }^{522}$ Other programs are designed for educational purposes, such as the National Endowment for the Humanities (NEH), which used Patton's infamous "Blood and Guts" speech as a learning tool. In this program, students compared and contrasted one of Patton's and Civil War hero Colonel Joshua Chamberlains' speeches. The NEH also provided lesson plans made for teachers. ${ }^{523}$ Several societies and chapters of national organizations took on the Patton name as well. There is a General George S. Patton, Jr. Chapter of the Sons of the American Revolution, a paternal organization of male descendants of Revolutionary War soldiers,

\footnotetext{
522 "Patton Veterans Project," https://pattonveteransproject.org/mission-history/.

523 "EDSITEment!: The Best of the Humanities on the Web," https://edsitement.neh.gov/launchpad-speechthird-army-george-s-patton-jr.
} 
in Los Angeles, California. Similarly, there is a General George S. Patton Polish Legion of American Veterans Post \#11 in Detroit, Michigan. The General George S. Patton, Jr. Historical Society, "Founded in 1970 for the purpose of preserving the memory of General Patton and the men and units he commanded" also helps keep the memory of the late general alive. ${ }^{54}$ Ironically, other organizations make money from restricting the use of Patton's image, such as one company called CMG Worldwide that specializes in protecting clients' images and likenesses and perpetuates their remarkable legacies by developing licensing programs. Consultants are available to help navigate the process of using Patton's likeness. ${ }^{525}$ Conversely, a troop of re-enactors and impersonators, branding themselves as living historians, are "dedicated to the preservation of [Patton's] history and his command" while they "re-create and re-enact the period and bring history alive to audiences all over the world." 526

While remembrance and the advancement of desired cultural beliefs were certainly key motivations for constructing and dedicating Patton public memory sites, so too was monetary profit. Commodification, the act or process of changing something into a commodity that can be bought and sold, potentially leads to exploitation, particularly in terms of narrative consumption. ${ }^{527}$ For example, sightseeing tours are available for those who wish to see a handful of public memory sites dedicated to Patton in Europe. Stephen Ambrose Historical tours offers a carefully curated 12-day "In Patton's Footsteps" tour that includes a guide. For the fee of $\$ 4,300$ per person (flights

\footnotetext{
524 "The Patton Society," http://www.pattonhq.com/member.html.

525 "General Patton," www.GeneralPatton.com.

526 "Patton and His Third Army Living Historians," http://www.pattonthirdarmy.com/.

527 "Commodification," in Open Education Sociology Dictionary, accessed September 10, 2020, https://sociologydictionary.org/commodification/.
} 
not included), tourists visit sites and battlefields significant to Patton's Third Army, including Normandy, Brittany, Mont-St.-Michel, the Falaise Pocket, the German border, and the Battle of the Bulge. ${ }^{528}$

Some non-profit organizations also take advantage of the Patton name, not solely for remembrance purposes per se, but for other noble efforts. Spearheaded by Helen Ayer Patton, the general's granddaughter, "The Patton Alliance is an international network of five independent non-profit organizations, centered on the history and extraordinary leadership abilities of General George S. Patton Jr. and the Patton family's legacy." The Alliance purportedly supports a wide range of philanthropic and fundraising efforts around the world with the intent of fostering peace across national borders through shared cultural experiences, education, and the provision of assistance to veterans of war. This organization spans several countries in Europe, each with distinct, albeit somewhat related, missions. ${ }^{529}$

As the Patton ASBL (association without lucrative purpose) Luxembourg asserts, the story of General George S. Patton, Jr. is inextricably linked to the history of Luxembourg, and the non-profit organization dedicates itself to working with veterans and fostering remembrance for future generations. The organization's mission also focuses on thought leadership (especially among young people, although it is unclear what that entails), the arts and cross-cultural understanding, integration, and inclusion. Although connecting Patton to cross-cultural understanding, integration, and inclusion is

\footnotetext{
528 "Stephen Ambrose Historical Tours: In Patton's Footsteps," https://stephenambrosetours.com/tour/inpattons-footsteps-the-battle-of-normandy-tour/.

529 "The Patton Alliance: George S. Patton Jr. Legacy," www.pattonalliance.org.
} 
presumptive, this ASBL did successfully launch a free concert in Luxembourg to commemorate the 70th anniversary of its liberation and the Battle of the Bulge.

Similarly, the Germany-based Patton Stiftung (Trust) founded by Helen Patton in 2005 has a mission of fostering the peace that her grandfather helped establish in Europe in 1945. The stiftung focuses on supporting multicultural projects in various fields of interest, such as the visual and performing arts (concerts, theatrical performances, exhibitions, and film projects), sustainability (environmental protection and urban gardening projects across Europe), innovative workshops and seminars in the humanities, and support for veterans of different nationalities.

The Patton Stifteise in Sweden provides a peaceful sanctuary for military veterans and families to recuperate from the effects of active war zones. Located in the middle of a quiet forest in Backsjön, Sollefteå, the organization offers accommodations and various programs to meet their constituents' special needs. Poland's Patton Foundation, whose mission may more closely align with Patton's character, promotes peace by honoring the service and sacrifice of Polish \& U.S. Army Veterans, while educating the public and inspiring a new generation through the preservation of the memory and sacrifice of heroes from the major conflicts of the 20th and 21 st centuries. This organization meets its goals by helping veterans of the Polish armed forces and the closest members of their families; helping families and soldiers of the Second Conspiracy and the Anticommunist Uprising in Poland in the years 1944-1963; establishing contacts with veteran organizations of the U.S. and Polish armed forces; promoting the traditions and values presented by General Georg S. Patton in Poland and among Polish communities in the United States and around the world; developing scientific, historical, and economic 
cooperation with American organizations and the Polish diaspora in the United States and around the world; and working together with all Polish organizations having a national and global profile.

Aside from these efforts, Helen Patton also established a Patton Legacy Sports program and a publishing company. ${ }^{530}$ She remains passionate about telling the personal stories of World War II soldiers and promoting the philosophies of nation, war, and peace shared by her grandfather and the entire Patton family. Her publishing focus is on intimate writings from or about soldiers on the battlefield. Patton Legacy Sports reports to be "dedicated to preserving the legacy of General George Smith Patton, Jr. OLY (Olympian) and his commitment to athleticism, self-discipline, camaraderie, strategy, and courage." Using charitable and educational means to support athletes, competitions, and organizations that peacefully interact across borders, Patton Legacy Sports intends to foster mutual respect, remembrance, and appreciation and nurture better understanding of service members' sacrifices. ${ }^{531}$

One definition of culture suggests that values and beliefs are incorporated into or reflected by physical traces of the past, or material culture, which helps explain why we can learn so much from the artifacts and objects that played an important role in people's lives. ${ }^{532}$ Objects rarely have any one single, fixed, and unchanging meaning. Anthropologist Clotaire Rapaille suggested that culture could be thought of as a series of codes that we learn while we grow up and that shape our behavior in different areas. Rapaille's concept of cultural codes suggests that every artifact reflects certain national,

\footnotetext{
530 "Legacy Sports," http://helenpatton.com/legacysports/.

531 "Patton Legacy Sports: George S. Patton, Jr. OLY," www.pattonlegacysports.org.

${ }^{532}$ Arthur Asa Berger, What Objects Mean: An Introduction to Material Culture (Walnut Creek, CA: Left Coast Press, 2014), 17.
} 
cultural, or subcultural attitudes and values that have been imprinted on people within a given culture from an early age. Artifacts from that culture, then, serve as a means of discerning these hidden codes. ${ }^{533}$ Traces of the Patton collective memory are visible through cultural codes left by humans in the years since Patton's death, and if one seeks to uncover the popularity of Patton, artifacts from popular culture may provide clues.

The Patton legend, a lasting phenomenon or cultural code, reflected in leisure activities the same attitudes towards him as other forms of projection. Patton became well represented and commodified across various forms of popular culture including games, toys, comic books, trading cards, and movies. Board games centering on Patton and his combat exploits allowed for a unique way to learn about his battlefield travails. Patton action figures, trading cards, toys, and comic books are now sought-after, monetarily valuable collectibles that once introduced Patton to children. While not always enacted in the public, per se, they were certainly advertised in public venues and contributed to collective memory.

Although it may be viewed as a niche activity, the practice of collecting can be quite varied. Stamp and comic book collectors are just two variants of collecting. Others include people who are interested in military memorabilia or artifacts (which may involve the exchange of considerable amounts of money), action figures or toys, and games. Collectors form communities, of sorts, and within those communities reside traces of the Patton collective memory. Members of these communities express their sense of self through their possessions, the visible representations of their judgement and taste. Collections may symbolize collectors' occupation or heritage and demonstrate many

${ }^{533}$ Ibid., 103-04. 
"self-enhancing motives" such as "seeking power, knowledge, reminders of one's childhood, prestige, mastery, and control." Furthermore, the transformation of objects that are "mundane, ordinary, and common" into sacred icons, or those that are "extraordinary, special, and capable of generating reverence" may occur in the process of collecting. Objects associated with historic people or events increase in monetary value, particularly those commodified through auction houses, and the price-inflating provenance of an item increases the perceived "value" of that person or event. ${ }^{534}$

Patton-based popular culture was commodified and made available for consumption by collectors and non-collectors during Patton's lifetime. The comic book War Heroes, No. 5, July-September 1943 demonstrates the reach of Patton's popularity, which included people of all ages. ${ }^{535}$ Comic books such as these were part of the effort to boost morale on the home front during World War II. Later, through the process of commodification, they helped maintain Patton in the collective memory of Americans, especially amongst comic book collectors. Of course, Patton's death led to a surge of material culture that capitalized on other hobbies, such as stamp collecting. ${ }^{536}$ The Envoy of the Grand Duchy of Luxembourg issued a set of commemorative stamps in 1947, which recognized Patton's contribution to the liberation of Luxembourg during World War II. Luxembourg was not alone. The United States, Belgium, Guyana, the Marshall Islands, and Sierra Leone also issued Patton commemorative stamps. Patton appeared on several envelopes, postage stamps, and cancellation stamps in the United

\footnotetext{
${ }^{534}$ Russell W. Belk, et al., "Collectors and Collecting," Advances in Consumer Research 15 (1988): 550551. Accessed September 10, 2020. https://www3.nd.edu/ jsherry/pdf/1988/Collectors\%20and\%20Collecting.pdf ${ }^{535}$ War Heroes, vol. No. 5 ( July-September 1943). Comic book copy held at The General George Patton Museum.

536 "Luxembourg Commemorative Stamp Folder," in Patton Archives (The General George Patton Museum, 1947).
} 
States, most recently in 2013. First day covers (envelopes) marked the first day of issue of a commemorative stamp. Purchased at the post office, people placed their commemorative stamps on the envelopes and mailed them, typically to their own home. Many creative people mailed their covers from a unique place, such as Fort Knox, Kentucky or Patton, Pennsylvania, to get those particular postmasters' stamps on the envelopes. Similarly, in 1952, Topps Trading Card Company released a series of 135 "Look 'N See" cards that showcased famous historical figures, including one featuring Patton. Along with stories of the individual, there was a hidden message to "spy." To "spy" the question, collectors placed a piece of red cellophane included in the pack on the back of the card to uncover the answer. Collectors could purchase sets for $1 \varnothing$ or $5 \phi$ that included chewing gum. ${ }^{537}$

Intentionally coinciding with the release of the movie Patton (a key progenitor of commodification), the 1970s brought a flurry of games centering on Patton that capitalized on his popularity. These role-playing games allowed individuals to go a step further than other commodified artifacts of the Patton collective memory by permitting players to imagine themselves in Patton's role as a combat commander. After playing these games, participants likely understood Patton's predicaments, gained a greater appreciation for his achievements in World War II, and perhaps self-identified with the Patton legend to some degree. For example, Research Games, Inc. developed the "Major Battles and Campaigns of General George S. Patton" board game in 1974. It allowed players to assume the role of Patton in Sicily, the Normandy breakout, and the Battle of the Bulge. Since 1969, Strategy and Tactics magazine included a hex board game with

\footnotetext{
${ }^{537}$ Examples of Patton stamps, envelopes, comic books, games, and trading cards are held at The General George Patton Museum.
} 
every new issue. "COBRA: Patton's 1944 Summer Offensive in France” came with issue 65 (November/December 1977) and offered a scaled simulation of the Allied breakout from the Normandy peninsula in the summer of 1944 and culminated with the encirclement of German troops in the infamous Falaise Pocket.

The trend continued in the 1980s. "Patton's $3^{\text {rd }}$ Army: The Lorraine Campaign, 8 Nov.-1 Dec. '44," again by Strategy and Tactics in issue 78 (January/February 1980), allowed players to act out the Lorraine Campaign that took place from November to December 1944. "Patton's Best” board game by Avalon Hill Game Company, released in 1987, put players in the commander's seat of a Sherman tank in the $4^{\text {th }}$ Armored Division during World War II. Interest continued well into the 1990s with "Bastogne: Crossroads of Death," released in 1991 by the Pacific Rim Publishing Company, which, since 1987, produced portable war games such as this one that highlighted several of Patton's units from the Battle of the Bulge.

Even with the proliferation of video games, board games made a stand. "Patton in Flames: Breaching the Iron Curtain" by the Australian Design Group in 2000 was another hex board game that accommodated up to six players. In this version, players imagined the world after World War II in which Patton was still alive and led a war against the Soviet Union. In Strategy and Tactics Issue 233 (March/April 2006), players read about World War II in Europe in September 1944 and played "Dagger Thrusts: Montgomery \& Patton, September 1944," a game that decided what should have been given priority: General Patton's plan to cross the Rhine River or the doomed Operation Market Garden. "Patton's First Victory" board game by Decision Games was a simulation of Patton's Tunisian Campaign. Released in 2011, it included a computer version of the game. Most 
recently, "Bitter Woods: The Battle of the Bulge" board game, released in 2014 by Compass Games, allowed players to recreate Patton's famous relief of Bastogne. While gaming certainly changed over the years since Patton's death in 1945, the fact remains that he left an indelible mark on that community. Video games replaced board games to a large extent, which also took advantage of Patton's persistent popularity: Xbox 360 released a Patton game in 2012. ${ }^{538}$

The memory of Patton was on full display through widely recognized toys as well. Capitalizing on a sense of personal nostalgia, and as part of their G.I. Joe Classic Collection, Kenner released their General George S. Patton action figure in 1997, second in the Historical Commanders Edition. Included was Willie, Patton's beloved bull terrier who, for the public, became inseparable from Patton. General Dwight D. Eisenhower was first in the edition. Hasbro also created a General George S. Patton action figure as part of its G.I. Joe Classic Collection in 2000. Pre-ordering required two installments of \$24.99. "One of the greatest generals in history - captured in all his glory. 'Old Blood and Guts,' General George S. Patton was tough as nails," the packaging remarked. To commemorate G.I. Joe's $35^{\text {th }}$ anniversary, Hasbro portrayed Patton, complete with a swagger stick, sheepskin jacket, Willie with dog tags, helmet, pistols, I Armored Corps shoulder patch, and U.S. and Army flags, as the first issue in its G.I. Joe Classic Collection. The $21^{\text {st }}$ Century Toys Company also released an action figure of Patton in 2002, which depicted Patton during the Battle of the Bulge. Collectors purchased an action figure of Patton dressed for the Tunisian Campaign from the same company. Finally, Dragon Models, Ltd., in conjunction with The History Channel, developed

\footnotetext{
${ }^{538}$ For all toys, games, and action figures, see the artifact collection at The General George Patton Museum.
} 
another action figure in 2003 that depicted Patton while at the Desert Training Center in California in 1942 as I Armored Corps Commander.

More often than not, news media as a public forum shapes the creation of a collective memory. As an expression of collective memory, public memory, then, can also be understood as a technique used by memory workers to capture an event midstream or strategically freeze it at its potentially strongest moment of meaningful representation. ${ }^{539}$ Take, for instance, news coverage of Patton during the World War II years: when understood as a form of memory construction and framework, newspapers' roles in the creation of the Patton legend in the 1940s becomes clearer. Although television or social media outlets rarely frame their programing or output as a special time for remembrance, typically advertising them as things that are interesting and worth knowing about, they do offer the main sources of information people consume about many historical events. ${ }^{540}$ The framework used by Hollywood, television, and the Internet is at the most basic level of exposure, and the public often consumes that exposure in a public or shared setting. Today, both television and the Internet still plaster messaging about Patton, often with little variance from the picture projected by 1940s newspapermen. At the same time, older forms of storytelling provide clues regarding the construction of collective memory. Aside from newsprint journalism, popular media, documentary film, and oral tradition, public and collective memory borrows from the structure of narrative as seen in drama, literature, film, and photography. ${ }^{541}$

\footnotetext{
539 Phillips, 158.

${ }^{540}$ Irwin-Zarecka, 191.

${ }^{541}$ Ibid., 155-56.
} 
The Big Picture featured Patton during one of its famous soldier highlights. Aired in 1960 during the aftermath of geopolitical and military turmoil in Korea which fueled anxiety about the state of the U.S. military and the fighting prowess of American men, "The General Patton Story" brought to the television screen a tale that reminded American viewers of their World War II glory. From 1945 to 1975, victory culture - the spirit of triumphalism pervading American culture in the early post-World War II years, waned then virtually ended in America. ${ }^{542}$ Yet for twenty-eight minutes, viewers listened to the voice of Ronald Reagan during episode 468 and watched as he brought back to life one of their heroes. Previously, the same series highlighted Patton's “Famous Third Army" in episode 217, which aired in 1952. Although not about Patton specifically, he did make several appearances in that episode. From 1951 to 1964, the United States Army Signal Corps Pictorial Service produced the series of documentary television programs that aired on $\mathrm{CBS}, \mathrm{ABC}$, and DuMont networks for 828 episodes and reran in syndication on 366 local stations into the early 1970s. Showing weaponry, battles, and biographies of famous soldiers, the half-hour weekly program featured famous or beforethey-were-famous actors and actresses. Master Sergeant Stuart Queen, a World War II and Korean War combat broadcaster veteran, hosted and introduced the profiles. The Big Picture was the official television report by the Army to its members and the American public. Conceived as a way to use film footage accumulated by the Army and packaged in a way that was attractive to commercial television audiences, the series intended to

\footnotetext{
${ }^{542}$ For an examination of "victory culture," see Tom Engelhardt, The End of Victory Culture: Cold War America and the Disillusioning of a Generation (Amherst: University of Massachusetts Press, 2007), 61.
} 
foster a sense of patriotism and pride in the American armed forces and had an initially positive reception. ${ }^{543}$

Arguably the most prolific and important agent of the Patton legend was the movie Patton. No other narrative form did more to formulate opinions of Patton in the modern mind. But it is also the form of public memory that skewed the narrative more than any other and to greater depths. If imitation is the sincerest form of flattery, then the references to Patton in other films, television shows, and other media are a testimony to the quality of this film. ${ }^{544}$ The movie, aside from references and parodies in a multitude of shows and characters, ranging from The Simpsons to The Muppets, had tremendous success at the box office in its own right. ${ }^{545}$ The movie was nominated for ten awards and won seven including Best Picture and Best Actor during the 1971 Oscars, beating out a popular anti-war film, MASH. It grossed \$16 million dollars (over \$100 million in 2019 dollars when accounting for inflation) despite its release during an anti-war climate. The movie was incredible popular. Variety magazine reported the film earned $\$ 61.7$ million in domestic box office sales, which places it number four in the list of most successful pictures since it hit the big screen. ${ }^{546}$ The film currently rates eight out of ten stars on the Internet Movie Database that also places it at number seven of the greatest war films of all time, between Full Metal Jacket and Platoon. ${ }^{547}$ The American Film Institute also

\footnotetext{
543 "U.S. Army "The Big Picture" TV Show Operation Amigo 73742," https://archive.org/details/73742TheBigPictureOperationAmigo.

${ }^{544}$ Sarantakes, 175.

545"Bart the General/References," https://simpsons.fandom.com/wiki/Bart_the_General/References.; "Muppet Wiki," https://muppet.fandom.com/wiki/Patton.

${ }^{546}$ Sarantakes, 129.

547 "Top 25 Greatest War Movies of All Time (The Ultimate List)," https://www.imdb.com/list/ls055731784/.
} 
considered it one of the top 100 movies ever made. ${ }^{548}$ This was a testament to Patton's immense popularity, but the movie began driving the legend thereafter. Until the film's release, populist books were the harbingers of the legends and myths surrounding Patton. The movie had a much farther reach.

Hollywood generally consults with the military when making war movies and the different branches offer technical advice, help with storyline development, and even the use of equipment. The armed forces realized early on that movies aided recruitment and their efforts to inform the public and Congress of their activities, among other benefits. The service branches developed guidelines in which any cooperation must be to the military's benefit and must come at no cost to taxpayers. ${ }^{549}$ As an institution, the military shaped which movies were made and how events were depicted. Filmmakers queried about making a movie about Patton as early as 1950, when Columbia Pictures first expressed an interest. However, the Department of Defense wanted to get Beatrice to agree first, which she emphatically did not. Beatrice had a grudge against the press, and for good reason - she blamed the press for Patton's several media fallouts. TwentiethCentury Fox became interested in the project in 1951, knowing that war made for good drama. However, the Army was not overly eager to highlight the life and career of one of its more rebellious generals, as the post-World War II Bradley-led Army was want to view Patton, and wanted only those films that reflected well upon the military. Fox Studios approached Paul Harkins, author of Drive and former staff officer under Patton, to get his thoughts on the project. Harkins was under the impression that Patton was an

\footnotetext{
548 "AFI's 100 Years...100 Movies: The 100 Greatest American Movies of All Time," https://www.afi.com/100Years/movies.aspx.

${ }^{549}$ Lawrence H. Suid, Guts \& Glory: The Making of the American Military Image in Film (Lexington: The University Press of Kentucky, 2002), 12.
} 
American hero who belonged to the entire nation and whose story deserved representation on film. However, the Patton family still wanted nothing to do with the publicity that would inevitably come from a movie.

Fox purchased the movie rights to Blood and Guts Patton, Lucky Forward, and Ordeal and Triumph, the latter being the main source for the screenplay. ${ }^{550}$ Interestingly, General Omar Bradley emerged as a major hero of the film, a development that was no accident. The producer sent the screenwriter a copy of a New York Times Magazine article on Bradley with a note: "'It is a fact that Bradley originally conceived and ordered a number of the projects which Patton executed so brilliantly. Let's credit Gen. B. wherever + whenever we can in the interest of fairness and accuracy."' 551

There is no strong evidence of that assertion outside of Bradley's own memoirs, who was incredibly jealous of Patton. Bradley had the opportunity to ensure that his legacy heavily influenced production when given the job of advisor for the film, which did the memory of Patton no favors. And if there was spin on a memory, it was certainly on Bradley's. As historian S. L. A. Marshall, no admirer of Patton himself, put it, the soldiers of World War II were not impressed with Bradley in the least. They scarcely knew him. He was not flamboyant like Patton and did not get to the front much to visit troops. The idea that Bradley was "idolized by the average soldier is just rot." 552 Bradley was ambitious in his own right and wanted command all to himself, a point that he makes in his memoirs. He did not appreciate that Patton biographers picked up on his insecurities as it ran counter to the reputation he and the willing wartime correspondent

\footnotetext{
${ }^{550}$ Sarantakes, 34-38.

${ }^{551}$ Ibid., 53.

${ }^{552}$ Carlo D'Este, Eisenhower: A Soldier's Life (New York: Henry Holt and Company, 2002), 404.
} 
Ernie Pyle built, the portrayal of Bradley as the quaint "G.I. General." He pointedly downplayed any rivalry he had with his former boss. Bradley was a timid commander and his conservatism caused him to miss opportunities, ones that Patton presumably would have exploited given the chance, such as the oft-cited failure at Falaise Gap in which Bradley allowed an entire German field army to escape capture or destruction. ${ }^{553}$ Most important to the producers was the question of access - they wanted to get as much advantage as they could from Bradley since he had connections to men in the Pentagon whose agreement the film project required, and therefore promised to present Bradley "in only the most accurate - and therefore the most favorable - light.” Bradley insisted that his character get adequate screen time and that he wanted Fox to hire him as an advisor, which they did. In the end, Bradley sold his name. The conditions under which he did so "show more of the man's true nature than the legend he had acquired during the war." 554

Yet, even with a hostile insider to the Patton legacy on set and a screenplay that made Bradley look good at the expense of Patton, who was portrayed as a rebel against the system, the Patton legend emerged victorious. In the producer's own words, the movie's intent was to be "an inspirational film which will bring only credit to General Patton, the Army, and the United States." It was clearly a film intended to do exactly what it did: mobilize public opinion. According to the treatment writer, "George S. Patton, Jr. was not only a great fighting General of World War II, perhaps the greatest fighting General of that war, a fantastic and colorful man of larger-than-life size dimensions, he was also one of the most pitiful victims of World War II, a figure worthy

\footnotetext{
${ }^{553}$ Richard H. Rohmer, Patton's Gap: An Account of the Battle of Normandy, 1944 (New York: Beaufort Books, 1981).

${ }^{554}$ Sarantakes, 88-90, 93-97.
} 
of comparison to the mythic heroes of ancient Greek tragedy." The treatment prior to the screenplay established a strong, dramatic narrative, breathed life into Patton, and made him appear sympathetic. The treatment turned Patton into an appealing, dramatic, and exciting hero. It gave little heed to technical military matters or facts: instead the film focused on a good story. It was intended to be "emotionally accurate" or "poetically accurate" rather than factual and it was infused with human values, not technical impediments. ${ }^{555}$

In the film, George C. Scott played a better Patton than Patton did. Scott's portrayal was exactly how Patton wanted to be remembered, which mirrored the public image he so carefully branded. "The result was that the picture that most Americans have when they think of Patton is the one he created for the press, which was transferred to the movie." 556 The film was not without its critics, initially drawing some conflicting reviews. Most naysayers praised George C. Scott for his powerful portrayal of Patton yet believed Patton appeared as " "the last humanist warrior...in an age increasingly dominated by warfare-technocrats, computers, and...was an 'archetypal military maniac, a Genghis Khan of the Western front." 557 However, the preponderance of awards it received and the popularity the film had amongst moviegoers belied anything the critics doled out.

As is so often the case, Patton was less about Patton or even World War II than a social commentary on the times in which it appeared on screen. "The public often decides how to determine the meaning of the cultur[al] product it consumes." The same

\footnotetext{
${ }^{555}$ Ibid., 46, 49-50.

${ }^{556}$ Lovelace, 118.

${ }^{557}$ David Wilson, "Patton," Sight and Sound 39 (Summer 1970): 160.
} 
public can "imitate art in ways that often seem surreal." $" 558$ As a pre-screening, the movie showed at West Point in 1970 and "'many cadets were enamored with the Patton image and still believed that wars could be heroic conflicts between men of honor.",559 The film's release during the Vietnam conflict suggested a nostalgic desire to relive the triumphs of warriors who fought in wars where good and evil were clearly apparent, as were protagonists and antagonists, heroes and villains. The movie's popularity indicated the continued importance to the nation of the heroic warrior figure. Nostalgia is more than a wistful memory of past events or people; rather it is a desire to regain a period when the ritual of battle proceeded according to clearly recognized classic motifs. ${ }^{560}$

Reeling from the debacle of American involvement in Vietnam and the growing realization that the U.S. foreign policy of containing the spread of communism was failing in that region of the world, many Americans clamored for something, anything, which would remind themselves of the goodness and righteousness of the cause of democracy, when America fought good wars and won. As it were, the film opened a window into the mindset of American society in the earliest stages of the post-Vietnam War era. The film allowed Americans to see themselves as they were and how they wanted to be. Patton appealed to simple but strong national myths, perhaps better described as ideals, while exposing more complex truths about the use of power abroad. Released during an era of insecurity and distrust in U.S. institutions, "For many...Patton contained a powerful statement about the importance of self-reliance and the providential mission of the United States, and at the same time it stressed the importance of strong

\footnotetext{
558 Sarantakes, 185.

559 Joseph Ellis and Robert Moore, School for Soldiers: West Point and the Profession of Arms (Oxford University Press, 1974), 162.

${ }^{560}$ Linenthal, 44-45.
} 
leadership." ${ }^{561}$ It allowed people to see themselves as they wanted to be seen, in the same triumphant picture so common in the U.S. after World War II. Maybe moviegoers were nostalgic for a time when the U.S. military had winners in its ranks. For the nation at large, perhaps that is part of the legacy of Patton - or at least the legacy of Patton since the movie's release.

Regardless of the film's impact on the collective psyche of Americans, Patton certainly changed how many thought of its main character. When considering the Patton legend and legacy, it is impossible to separate the movie and the man. As one Patton historian noted, you can "Ask virtually any American born after World War II what immediately comes to mind when the name 'Patton' is mentioned, and chances are they will conjure an image of a large, empty stage dominated by an enormous, oversize American flag." The movie turned Patton the legend into a folk hero, just like the cowboy hero of the Old West. He entered into American mythology and became the symbol of an older, simplistic America untouched by the social change, political doubts, and uncertainties that came with the 1970s. And so, for the years since the release of the movie, the primary sources of the collective memory of Patton became "a popular film and the opinions of a general [Bradley] who detested him but who owed him a giant debt for his support during the final months of World War II." ${ }^{\text {562 }}$ Of course, it wasn't the film that made Patton famous - he already captured his fame during his lifetime. His success, which was legendary by itself, was no accident. It came from a lifetime of determined study and practice. But the legend was not merely about his success. The legend was manifest by his success, a legend that found its way onto the big screen. In a way, Patton

${ }^{561}$ Sarantakes, 5, 7.

${ }^{562}$ D'Este. A Genius for War, 1-2. 
became more real than Patton. And the film became one of the reasons Patton remained a major figure in the public's understanding of World War II.

The movie turned Patton into a popular culture icon and had an impact on other productions as well. Pop culture references show the long shelf life of Patton. Sesame Street Presents Follow That Bird (1985), The Tonight Show, Sanford and Son, Punky Brewster, The Simpsons, The Adventures of Brisco County, Dexter's Laboratory, Family Guy, Futurama, Sealab, Space Jam, Antz, Toy Story 2, Recess: School's Out, Daddy Day Camp, The New Guy, Jackass 2.5, Van Wilder: Freshman Year, The Nine Lives of Fritz the Cat, Royal Flash, Smokey and the Bandit, Superman III, Blades, The People vs. Harry Flint, Pleasantville, Small Soldiers, South Park: Bigger, Longer and Uncut, Spun, The Movie Hero, Stick It, Avatar, Pleasantville, News Radio, The West Wing, NCIS: Naval Criminal Investigative Service, The Gilmore Girls, Islands in the Stream, Batman, Master Science Theater 3000, The Critic, News Radio, Third Rock from the Sun, Just Shoot Me, Battlestar Galactica, The King of Kong, A Fistful of Quarters, Seinfeld, and Saturday Night Live all referenced or parodied the movie in some way. Even the Jim Henson Company satirized the movie in a 1999 calendar in which the Muppet characters mimicked various movies. In it, Rizzo the Rat shown in uniform as "Ratton," stood in front of a U.S. flag. ${ }^{563}$

In the made-for-television special The Last Days of Patton, Scott once again played the part of the controversial general in what he considered a more accurate portrayal. Frustrated with the projection of Patton as an egotistical warmonger, as some critics claimed, Scott was intent on demonstrating that Patton was an "admirably complex

\footnotetext{
563 Sarantakes, 166-72.
} 
man. Beneath his rough exterior, it seems, there lurked a patrician man of learning, warmth, and good humor." With a plot taking place in post-war Germany in 1945, the film portrayed Patton in his role as military governor of Bavaria and all his troubles with the denazification program, covering the last few months of his life. The film cajoled viewers to admire Patton regardless of his excesses. ${ }^{564}$ Yet, Scott's desire to soften Patton's image in this memory projection medium did not have the sweeping effect Patton had on the American public. Far fewer people watched it.

In 1995, A\&E Television Networks released a DVD documentary biography based on D'Este's book General George Patton: A Genius for War, which was part of a television series that ran on several different networks from the 1960s to 2012 and launched again in 2017. In 2007 Columbia River Entertainment released a two DVD set of videos called The Great Generals which highlighted the careers of notable Army generals including John Pershing, Dwight Eisenhower, Omar Bradley, Joseph Stilwell, Henry Arnold, Douglas MacArthur, George Marshall, and of course George Patton. From April 10 to June 26, 2009, The History Channel ran a weekly series titled Patton $360^{\circ}$, which featured a mixture of computer generated imagery, archival footage, recreations, and interviews with World War II veterans and historians. The same studio released the series as a DVD set.

Although these are not the totality of films, television shows, movies, and documentaries about Patton, they do illustrate the extent to which filmmakers capitalized on the Patton legend. They also demonstrate the longevity of the Patton story, much like the publications discussed previously. This form of medium can often be more accessible

\footnotetext{
564 John J. O'Connor, "TV Weekend; George C. Scott in 'Last Days of Patton'," The New York Times September 12, 1986.
} 
to the average person as well, and with more reach, albeit with less depth. Regardless, films do help make sense of how deeply embedded Patton is in the public's imagination.

Just as Patton showed up in museums, roads, parks, memorials, statues, and organization names, people developed a marked presence for him in the online world as well. Some are not as obvious, such as one website with a cartoon that uses a quote from Patton about destiny to tell a story about a man summoning the courage to speak to an attractive waitress at a diner. ${ }^{565}$ Others are more overt, such as one that named Patton "Bad Ass of the Week." 566 Internet users are able to take an online quiz to see how much they know about Patton. ${ }^{567}$ Websites such as these sell advertisement space, so the impetus for capitalizing on the Patton name and collective memory is obvious.

One of the fastest growing digital mediums for information transfer is podcasts. ${ }^{568}$ The Joko Podcast, hosted by retired Navy SEAL Joko Willink, uses its platform to discuss the importance of discipline and leadership and included two separate two-hour long episodes that centered on Patton. ${ }^{569}$ Currently, there are at least nine other episodes from other podcasts that focus on the famous general. Several electronic books are available as well for those who have a preference for that medium. ${ }^{570}$ Dozens of Patton

\footnotetext{
565 "George Patton: A Man Must Know His Destiny," http://zenpencils.com/comic/george-patton-a-manmust-know-his-destiny/.

566 "Badass of the Week," http://www.badassoftheweek.com/patton.html.

567 "Military Tactics: The George Patton Quiz," https://quizzes.howstuffworks.com/quiz/military-tacticsgeorge-patton-quiz.

568 "Podcast Insights," https://www.podcastinsights.com/podcast-statistics/.

569 "Jocko Podcast," https://jockopodcast.com/. See episodes 213 and 214.

${ }^{570}$ For examples of audio and digital books, see Fred Adams, George S. Patton: Everything You Need To Know, (Emereo Publishing, 2014); Stephen E. Ambrose, Fateful Friendship: Eisenhower and Patton, (New World City, Inc., 2014); James Bankes, WWII: General George Patton/The Dark Mind of a Military Genius, (Self Published, 2015); Major Lawrence Fr. Camacho, The Leadership Development of Dwight D. Eisenhower and George S. Patton Jr.; Patricia Probert Gott, General Patton Rescues the Horses, (Norway, Maine: PRGott Books, 2016); U.S. Government, General George S. Patton: Operational Art, Battle Command Lessons in the Second World War, (Progressive Management, 2014); Scot II Laney, In Case of Doubt: Attack!: General George S. Patton and Corporate Leadership, (Lulu.com, 2011); Christopher S.M. Lyon, A Holy Warrior in an Unholy Age, (Theodosian Walls Publications, 2014); Charles M. Province, ed.
} 
titles published in traditional book form along with several others only available in digital format are available as audio books. A quick search on YouTube yields hundreds, if not thousands, of videos. Certainly, Patton's footprint in the digital and online sphere is considerable, reaching a wide range of audiences, with each click adding to the collective memory of "Old Blood and Guts" in this unique aspect of public memory.

For years, memory workers strove to maintain the collective memory of Patton in the forefront of public memory and spur tourism through the creation of monuments, memorials, museums, and memorialization projects. They planned and conducted commemoration ceremonies, created societies, and built statues to honor the war hero to foster a sense of identity through the recollection of a shared past and to remind themselves and others of past American greatness lest it be forgotten. They also organized charities capitalizing on his collective memory to help the less fortunate. Writers wrote books, filmmakers produced movies and documentaries, and website designers built web addresses that generated considerable amounts of revenue. The Army named streets, schools, and government buildings after Patton to foster a sense of connection between current service members and the institution's illustrious past. Companies sold action figures, toys and games. In doing so, each of these memory workers turned the collective memory of Patton into a public memory, one that in turn helped keep the collective memory alive. Even with those whose enactment did not occur in public settings, they were at least advertised for public consumption and should not be dismissed. It is remarkable that Patton remains entrenched in collective memory

Military Essays and Articles by George S. Patton, Jr. 1885-1945 (San Diego, CA: The George S. Patton, Jr. Historical Society, 2002); B. Odom, I Was Patton's Doctor: The Reminiscences of Colonel B. Odom, M.D., (CMP Productions, 2011); James Wellard, Following Patton: War Correspondent James Wellard with General George Patton and the Third Army, (Uncommon Valor Press, 2015). 
to the degree he is considering he died 75 years ago. This preponderance of evidence suggests that for American society, at least in some circles, there remained a place for Patton. Whether it was for political gain, financial gain, altruism, or for nostalgia, the reasons are as numerous as there are instances. However, what is undeniable is the magnetism the man had with so many and continues to have today. 


\section{CHAPTER VII \\ THE PATTON LEGACY}

The influence one man can have on thousands is a never-ending source of wonder to me. General George S. Patton, Jr.

Chapters I-VI explained in detail how, why, and by whom the Patton legend came to a position of prominence in the collective and public memory of Americans and Europeans. Seen as a means to create support for the war effort in the early 1940s, newspapers capitalized on a colorful braggadocio who demonstrated a knack for winning on the battlefield. And Patton delivered headlines in droves. Throughout the war, news coming to the home front constantly reminded Americans that as long as the Army had men like Patton there was hope. Several moments of indiscretion did little to dissuade fans of his utility, cause celébrès that many of Patton's military contemporaries also saw fit to ignore. Many who served under Patton or followed his campaigns came to identify with him in very personal ways, especially those who served closely with him, evidenced in fan mail and populist biographies. The publicness of that memory, the Patton legend as it were, solidified in several concrete forms of public memory after his death, a tragedy seen by many as the impetus that forwarded the trajectory of the legend, especially through the bent of conspiracy theorists. Memorials, commemorations, schools, roads, toys, games, movies, and many other public forms of memory bear the late general's name, lending evidence to the pervasiveness of Patton in the public's collective memory. 
However, the staying power of the Patton legend is not manifested anywhere more deeply than in the institution to which he dedicated his entire life: the United States Army.

Patton was first and foremost a soldier. Within the confines of the Army subculture, Patton is conspicuous. One need to look no further than the numerous places on Army installations named after him, such as the aforementioned Patton Hall, Patton Barracks, and Patton Museum. Even in far-flung places like Qatar there is an Army dining facility on Camp As-Sayliyah called "Patton's Own Middle East Café" where a portrait of him greets those who enter. There is a "Patton's Grab \& Go" for quick carry out food and a shrine to the general with his portrait and a large mural painting of him. One room is decorated entirely with pictures of the icon. Patton, more closely approximating hero status than perhaps any other soldier in the modern era, can be seen as a symbol or icon of virtues that the Army wants to extoll. For many Army leaders, past and present, he is the avatar of the perfect commander. For generations, United States Military Academy cadets "dreamed and prayed that we might have the opportunity and courage to live up to his legacy" as did cavalry and armor officers. ${ }^{571}$ After he reached hero status, Patton left for the institution a legacy that influenced tactical and operational doctrine, military leadership theory and practice, armored unit organization, and a blueprint for training troops and units.

And a hero he did become. Patton became an icon or symbol of the dashing and daring warrior, the general whom embodied the romantic ethos of the chivalric cavalry commander. Indeed, dead heroes do make the best heroes - for them, time stopped at the height of their popularity, even if the collective memory of them did not. Alan Axelrod

${ }^{571}$ Axelrod, Patton: A Biography, viii. 
understood that "Figures of myth largely represent the meaning we endow them with. To the extent that he has entered into American mythology, this is true of Patton, and the mythic Patton all too readily overshadows the historical Patton, a soldier and a leader of soldiers, obscuring the important question that needs to be asked: What is Patton's legacy to the Army of today?"572

That legacy cannot be overstated. It found its way into many different arenas such as in the ordnance branch when the Army named its first postwar tank after Patton and later three others. ${ }^{573}$ Almost every Army garrison in the United States and abroad named something after the late general: at many an Army post there is a Patton Hall, a Patton Barracks, or a Patton Road. In the combat branches, the combined-arms approach, including the use of air power, Patton's hallmark, became standard war-fighting doctrine. Patton's tough, realistic training regimen, complete with his "train the trainer" model, became common practice. An entire generation of officers claimed to carry his torch. Case studies on Patton's battles and leadership style became canonized at the U.S. Army Armor School and are taught at the Command and General Staff College to this day. At West Point, cadets walk past the inspirational statue of Patton outside the university library, dreaming of the opportunity to live up to the Patton legacy. ${ }^{574}$

Of course, part of the Patton legacy is the pride in which those who served under him displayed, but the preponderance of evidence does not stop there. ${ }^{575}$ Perhaps the most phenomenal aspect of the traction the legend achieved was the fact it thwarted all

\footnotetext{
572 Ibid., 174-75.

573 The Army named the M46, M47, M48, and M60 series tanks after Patton. He is the only individual the Army chose to name more than one tank after and the only main battle tank namesake since 1947 until the M1 Abrams (named after Creighton Abrams, a Patton acolyte). The M1 Abrams is the Army's current main battle tank.

${ }^{574}$ Axelrod, Patton: A Biography, viii-ix.

${ }^{575}$ D'Este, 813-14.
} 
efforts to derail it, evidenced in the negative writings by Eisenhower and Bradley as each of these men vied to out-shadow Patton and solidify their own legacies at his expense. After Patton's death, the leading generals "refought the war in the pages of their memoirs. ${ }^{" 576}$ During World War II, Eisenhower considered Patton his most indispensable field commander, as evidenced by his reluctance to rid himself of the troublesome general on several occasions, but after the war described Patton as a limited field commander who was emotional and impetuous. ${ }^{577}$ Bradley followed three years later with his first memoir, A Soldier's Story, condemning Patton as indifferent to supply, lacking self-discipline, and whose success could only be attributed to luck. Bradley's revisionism certainly influenced events and he castigated other generals besides Patton in his second memoir. ${ }^{578}$ It certainly did not help the situation when sections of Patton's diary became public, copied by Sergeant Joe Rosevich, making their way into the New York Times. In those pages, Patton wrote his true feelings about Eisenhower and Bradley, who could not forget or forgive Patton and his candor. ${ }^{579}$

From the assertions of these former commanders emerged a distorted picture of Patton and his methods. ${ }^{580}$ A ranking of the "100 Most Influential Military Leaders of All Time" placed Patton at number ninety-five, seventy-nine slots behind George C. Marshall, seventy-seven behind Eisenhower, forty-nine behind Bradley, and thirty two behind Montgomery. However, this ranking, conducted in 1996, was made by historians who use the past in vastly different ways than the average citizen, soldier, or Army

\footnotetext{
${ }^{576}$ Morningstar, 7.

577 Dwight D. Eisenhower, Crusade in Europe (Garden City, N.Y.,: Garden City Books, 1952), 81, 281-86.

578 Omar Nelson Bradley, A Soldier's Story (Westport, Conn.: Greenwood Press, 1975), 51-52.

${ }_{579}$ Morningstar, 253.

${ }^{580}$ Ibid., 8.
} 
officer. When contrasted with the plethora of popular culture websites that say the contrary, there is a noticeable divide between the public and academia. ${ }^{581}$ Patton's naysayers' opinions clearly had an effect on the Patton legacy trajectory but were not enough to slow it down, much less stop it.

The attempts to revise history started early. Three days after the German surrender, General Eisenhower assembled his senior commanders and held a meeting, during which Patton reported that Eisenhower spoke to the group in confidence on the necessity for solidarity in case a Congressional Committee questioned them in regards to the conduct of the war. Patton believed that the purpose of such solidarity was to serve as a cover up for criticism of Eisenhower's strategic blunders and to place blame on the outcome of the war squarely on the Germans. It was here that Patton first stated that he believed Eisenhower was running for President. ${ }^{582}$ Fortunately for Eisenhower and Bradley, Patton died: he was no longer in their way as they shaped their own narratives. Eisenhower and Bradley, along with their proponents and disciples, became role models and mentors for future generations of officers. The Patton types became persona non grata, and those of the Ike and Bradley mold became made men. Even most of Patton's subordinates did not fare so well in the post-World War II Army. ${ }^{583}$ With General Marshall's retirement, so too departed from the Army the idea that officers could swiftly be relieved with the possibility of forgiveness and redemption. ${ }^{584}$ And, as historian Thomas Ricks suggested, if the model general in the eyes of Marshall, Eisenhower, and

\footnotetext{
${ }^{581}$ Michael Lee Lanning, The Military Top 100 (Secaucus, New Jersey: Citadel Press, 1996), 348.

${ }^{582}$ George S. Patton, "Patton Diary," in The George S. Patton Papers (Library of Congress, May 10, 1945); "Memorandum of the Joint Chiefs of Staff No. 1067 (revised)," ibid.; D'Este, 740.

${ }^{583}$ Morningstar, 244.

584 Thomas E. Ricks, The Generals: American Military Command from World War II to Today (New York: Penguin Press, 2012), 451.
} 
Bradley was an "optimistic team player with a small ego and great ability to work with others," Patton did not fit the mold perfectly, to say the least. For example, the relatively unknown General William Simpson "personified the ideal of generalship that Army leaders would pursue in the postwar years, and indeed for decades to follow. It was not a bad model, but it contained some hidden dangers." For one, officers like Simpson were hardly inspirational leaders...most people could not identify Simpson at all and many have never heard the name, even though he was also an army commander during World War II. Those dangers plagued the Army for generations, for without the skilled leadership of Marshall the system produced a bland, uninspired, risk-averse corps of generals, especially as the officer corps developed a heightened culture of careerism and no longer faced the prospect of being fired for failure, inaction, or incompetence. When Eisenhower replaced Marshall as the Chairman of the Joint Chiefs of Staff, he implemented Marshall's system of managing general officers. However, when the cautious Bradley succeeded Eisenhower, risk-aversion and corporatism became the Army norm as Bradley appreciated team players (those who would not "rock the boat") far more than his predecessors. ${ }^{585}$

Soon after the Army War College's 1970 Study on Military Professionalism, Patton came back on the stage with the brilliantly iconic portrayal by George C. Scott in the title role of the movie Patton, which packed theaters during the same year. Admonitions from "Old Blood and Guts" in the film gave American audiences a jolt at the same time the Army remained mired in Vietnam and the Cold War. And Patton's opinions about the Soviets, the source of overwhelming concern for Americans since the

${ }^{585}$ Ibid., 108. 
beginning of the Cold War, sounded prophetic. There were obvious inaccuracies in the film, despite the efforts of the producer, George C. Marshall's former executive officer Frank McCarthy, and many were attributable to Bradley who served as senior technical adviser. Take, for example, the omission of Eisenhower and Bradley's errors in Tunisia, Sicily, France, and the Ardennes. The movie also left out Patton's designs to close the Falaise gap, his daring race to Metz, the clearing of the Palatinate, and the Third Army's rush across the Rhine River. Not only was Eisenhower above criticism in the film, his character never even made an appearance. Meanwhile Bradley's role was exaggerated, especially in Patton's breakout from the Normandy hedgerows. Bradley appeared as an even handed and realistic professional who brought sense to chaos while Patton came across as a profane, hard-hitting soldier who fought his battles using intuition rather than military logic. While Patton appeared bloodthirsty and vainglorious, Bradley was portrayed as down-to-earth and decent. The movie's advisers attempted to tarnish Patton's legacy by explicating Patton's success merely as a result of his fiery temper, desire for glory, and sense of history, and the film left many future officers who were inspired by the film failing to gain an appreciation of his methods. ${ }^{586}$

However, even as the high command sought to discredit the Patton legend and promote their own, Patton's popularity amongst the junior officer corps increased over time. As General Wesley Clark later recalled, "Many of my mentors at West Point and later would work hard to produce a 'Patton-plus' mentality - hard charging in combat, yes, but also able to deal with the intricacies of strategy and statecraft. In view of the challenges we face in peacekeeping operations today, we've never needed the 'Patton-

${ }^{586}$ Morningstar, 259-60. 
plus' mindset more." Patton was a student of war, always adapting and learning how best to accomplish a mission - this mindset is in part the legacy Patton had for later generations of military leaders. "He was a winner, a morale-and team-builder who adapted quickly and sought to master every challenge. We need leaders like that today." 587

Early American military involvement and actions in Korea, Vietnam, and during the forty-year Cold War was in many ways the legacy not just of Patton's generation, but also of Patton himself. For a short time, his tactical vision for maneuver warfare suffused the early post-World War II U.S. Army as several of his disciples, such as General Walton Walker, led military efforts in Korea before his death there in a jeep crash. And it was his former subordinates and family who kept alive his reputation, principles, and spirit. ${ }^{588}$ Patton's greatest cheerleader, his wife Beatrice, traveled widely, with the aim of doing all she could to keep his memory flourishing. At a seemingly endless series of ceremonies to dedicate statues, buildings, streets, and parks named after him in both Europe and the United States, Beatrice extolled his accomplishments and accepted in his name honors and awards from grateful cities, towns, and organizations.

\section{A Legacy of Leadership}

Historian and Patton biographer Alan Axelrod was perhaps the first to address in any real sense, as modest as it was, the meaning of the Patton legacy. While many of today's military leaders continue to value the legacy of the controversial commander, recent attempts to define what that legacy is, exactly, are the first of their kind and rare indeed. Within the Army's ranks there remain detractors, those who cannot see past the

\footnotetext{
${ }^{587}$ Axelrod, Patton: A Biography, ix-x.

588 Ibid., vii-viii.
} 
blusterous behavior and showmanship and recognize, much less appreciate, Patton's intent to inspire. Granted, these officers are those of the Bradley or Eisenhower vein, as Ricks pointed out. Scores of paeans to George S. Patton Jr. are just as easy to find as the many indictments lodged against him. But what are difficult to find, at least historically speaking, are attitudes that lie in between. As has always been the case, few seem to have had a moderate, let alone objective, opinion of the general. Patton polarized opinion during his lifetime and continues to do so. ${ }^{589}$

It would be a misread of the Patton legacy to frame Patton's influence on the Army only in terms of armored warfare at the operational level or his personality, which later generations of officers tried to emulate. In addition to his exploits on the battlefield and his many successes, Patton imbued the United States Army with a commitment to victory through individual initiative and personal leadership, a tacit and counterintuitive idea for an organization supposedly built on teamwork. This aspect of his legacy is less tangible than his tactical and operational lessons, but, for combat commanders, it is even more urgently indispensable. While many admire Patton the battle captain, many more relish Patton the legend, but most are uneasy and unfamiliar with Patton the man. Axelrod sought to find a balanced appreciation of "a great and greatly flawed figure, whose contributions to modern military doctrine and modern world history are profound and whose greatness and failings alike reveal as much about America - who we were, who we are, and who we have imagined ourselves to be - as they do about George Smith Patton Jr." ${ }^{.590}$

\footnotetext{
${ }^{589}$ Ibid., 2.

${ }^{590}$ Ibid., 7.
} 
The keystone leadership manual for the United States Army, Field Manual (FM) 6-22, established leadership doctrine for officers, warrant officers, noncommissioned officers, and enlisted soldiers of all Army components (Active Duty, Army Reserve, and Army National Guard). It outlined the fundamental principles by which Army leaders accomplish their given missions and care for their soldiers and serves as the basis from which new leaders learn to lead. The manual defined leadership, leadership roles and requirements, and how to develop leadership within the Army. It outlined the different levels of leadership as direct, organizational, and strategic, and described how to lead successfully at each level. FM 6-22 further established and described an Army leader's core competencies, which facilitate feedback, education, training, and development across all levels and reiterated the Army Values of loyalty, duty, respect, selfless service, honor, integrity, and personal courage. The "Warrior Ethos," the belief system in which soldiers put their given mission before self, the refusal to accept defeat, a refusal to quit, and the promise to never leave a fallen comrade, was an integral part of how the Army defined leadership. The manual incorporated leadership qualities of self-awareness and adaptability and described their impact on acquiring additional knowledge, improving the core leader competencies, and operating in constantly changing environments.

FM 6-22 was part of an evolution of Army doctrine. It supported and was an expansion of principles outlined in two capstone publications, FM 1 The Army, and FM 3-0 Operations. The publication also supported keystone manuals such as $F M$ (now Army Doctrine Publication, or ADP) 5-0 The Operations Process, FM 6-0 Commander and Staff Organization and Operations, and FM 7-0 Train to Win in a Complex World. In $F M 1$, the Army outlined the concept of BE-KNOW-DO to concentrate on the key 
factors of leadership. This concept is one that argued leaders' actions emerge from who they are and what they know. FM 6-22 expanded upon those principles and described the three character attributes and three core competencies required of modern military leaders. Character is based on the attributes central to a leader's constitution and competence comes from how character combines with knowledge, skills, and behaviors to result in leadership. ${ }^{591}$ Grounded in the Army Values, the institution's codified set of cultural norms, beliefs, and assumptions, was the idea of loyalty, a component of a leader's character. The bonds of loyalty extend beyond the institution and the Constitution into every unit and organization. It is a two-way commitment between leaders and subordinates. FM 6-22 invoked Patton's maxim on loyalty to illustrate its mechanics: "There is a great deal of talk about loyalty from the bottom to the top. Loyalty from the top down is even more necessary and much less prevalent."

As defined by the Army in its doctrinal publication on the subject, leadership is the process of influencing people by providing purpose, direction, and motivation while operating to accomplish the mission and improving the organization. Patton certainly checked all of those boxes during his career, and while there are a plethora of examples of how he demonstrated Army leadership principles, the methods used by the Army to train its members today, which represents part of the legacy he left for and adopted by the institution, are the focus of this portion of the study. Patton appeared more than any other leader in FM 6-22, with a margin of 3:1 over the next most cited individual, General Eric Shinseki. One component of Army-style leadership is the precepts of the Code of

\footnotetext{
${ }^{591}$ Field Manual 6-22 Army Leadership: Competent, Confident, and Agile, ed. Department of the Army (Washtington, DC: 2006), v.

${ }^{592}$ Ibid., 4-4.
} 
Conduct, a reflection of a soldier's selfless commitment to the nation, mission, and fellow soldiers. Developed and sustained through discipline, commitment to a codified value system, and pride in the Army's heritage, the Soldier's Creed also defined these attitudes and beliefs. FM 6-22 used Patton to remind readers that although wars "may be fought with weapons," they "are won by men. It is the spirit of the men who follow and of the man who leads that gains victory." ${ }^{" 593}$

As with many of military history's most notable commanders, understanding that individual's legacy for the profession of arms is a matter of recounting strategic, tactical, and doctrinal contributions. In the case of Patton, however, perhaps his most important contribution was less quantifiable but even more important than any he made in these traditional areas. As Axelrod noted, "Patton bequeathed to the army the ideal of the warrior leader." Every bit the romantic soldier, Patton sought to inspire his army with his seemingly archaic beliefs in the ideal of the chivalric cavalry officer. The modern Army calls this aspect of leadership command presence, the ability of a leader to create a cohesive and highly motivated force in large part through the power of his or her personality. A leader with a charismatic presence is one who demonstrates military bearing, physical fitness, confidence, and resilience. Physical characteristics also help establish presence. ${ }^{594}$ An effective army identifies with his leader, even to the point of assuming the identity of the commander, such as the case with Patton. Leaders project presence most likely to create a victorious force, one built on confidence, competence, and posture. Any intangible element that increases the effectiveness or efficiency of a military organization is considered a "force multiplier." Patton demonstrated for the

\footnotetext{
${ }^{593}$ Ibid., 4-10, 11.

${ }^{594}$ Ibid., 5-1.
} 
Army that the persona of the commander could be among the greatest force multipliers of all. This does not imply that all of today's Army leaders need or should imitate Patton, although it is plausible that some do. It does mean, however, that each leader must find his or her own warrior soul and project that onto the force he or she commands. "This is a lesson not readily learned at the War College, but it is a lesson embodied in the example of Patton." 595

Historians noted that few, if any, military figures in American history came close to comparison with General Patton in respect to his uncanny gift for getting fighting men to do things which they did not believe they were capable of doing, those dangerous things which they did not want to do, which they did not do unless directly exposed to "the personality, the genius - call it what you will - of this unique soldier who not only knows his extraordinary job, but loves it." Even those close to Patton, such as Codman, recognized that "an entire army... is galvanized into actions by the dynamism of one man. Even his military superiors find themselves irresistibly, if reluctantly, drawn into his magnetic field...."596

Others who worked with Patton extensively, such as Semmes, claimed that Patton's presence had immediate positive effects on those he led. Patton "gave them [II Corps] discipline in a miraculously short time [in Tunisia], and they fought well thereafter. However, many of his friends among the troops contend that no disciplinary miracle occurred but that the bringing together of American troops and a real American leader, willing to be seen and felt at the very front, was the true story of the

\footnotetext{
595 Axelrod, Patton: A Biography, 175.

${ }^{596}$ Farago, Patton: Ordeal and Triumph, 484-5.
} 
transformation that accompanied the arrival of General Patton in Tunisia."597 Patton knew, Semmes asserted, that a leader must have a sacred trust in their men and to their country, and they "are lower that the lowest thing that lives if you are false to this trust. An officer, no matter what his rank, must always be willing and anxious to take the chances his men must take." 598 And Patton always gave credit where it was due: "It is characteristic of Patton that he gave full credit to his staff officers and men for his success. This is undoubtedly one reason why they were so willing to do the almost impossible for him." $" 599$ According to FM 6-22, one of the many responsibilities of an Army leader is to encourage initiative and acceptance of responsibility. As quoted in the manual, Patton reminded the Army that a leader should "Never tell people how to do things. Tell them what to do and they will surprise you with their ingenuity."

One of the three attributes an Army leader possesses is that of intelligence. Demonstrating competence is key: it does not take long for subordinates to become suspicious of a leader who acts confident but cannot demonstrate competence. Army Leadership recalled that General Patton made it clear that leading from the front and making plans with a clear understanding of the frontline situation were keys to success. In a General Order to the Third Army, Patton stipulated:

The Commanding General or his Chief of Staff (never both at once) and one member of each of the General Staff sections, the Signal, Medical, Ordnance, Engineer, and Quartermaster sections, should visit the front daily. To save duplication, the Chief of Staff will designate the sector each is to visit.

The function of these Staff officers is to observe, not to meddle. In addition to their own specialty, they must observe and report anything of military importance.... Remember, too, that your primary mission as a leader is to see with your own eyes and be seen by your troops while engaged in personal reconnaissance. ${ }^{601}$

\footnotetext{
597 Semmes, 145.

598 Ibid., 157-58.

599 Ibid., 228.

${ }^{600}$ Field Manual 6-22, 11-6.

601 Ibid., 7-14.
} 
Achieving results is another Army leader's core competencies. While the successful execution of a plan is often based on prior work and requires situational understanding, supervision, assessment, implementation, and adjustment, the Patton legacy offers leaders a suggestion that runs counter to prevailing adherence to a slow planning and execution process. Often, "a good plan violently executed now is better than a perfect plan next week." 602 Fear and stress in combat dampens a leader's ability to achieve results. The suddenness, intensity, and life-threatening nature of combat are ever present, but it is ultimately the job of soldiers to kill. Leaders must understand human dimensions and anticipate reactions to stress. Patton understood this all too well and, as quoted in the manual, "All men are frightened. The more intelligent they are, the more they are frightened. The courageous man is the man who forces himself, in spite of his fear, to carry on." 603

The Army's manual on leadership also defined within the leader competencies the concepts of developing others, creating a positive environment, and preparing oneself. Historian James Morningstar noted that Patton warned the institution that officers who do not correct errors and praise excellence are valueless in peace and dangerous in wartime. As noted previously, one of the imprints Bradley left for the Army was that of a reluctance to relieve officers and offer an opportunity for redemption. "Patton," it seemed, "was long dead." In a study commissioned in 1970 by the Army Chief of Staff, "leadership had incorporated structures of statistical measurements that substituted selfinterests and promotions in place of efforts to win a war." To the soldiers, this meant,

602 Ibid., 9-4.

${ }^{603}$ Ibid., 10-4. 
"nothing was too sacred to be sacrificed on the altar of numerology." ${ }^{\prime 64}$ Patton, conversely, "believed in giving an officer a fair chance to attain his stride." If Patton knew that a subordinate did his best he made allowance for poor performance and in this way those who worked with him on a regular basis did better than they knew how. "It was inspiring to have served under him, something that his subordinates will never forget," one former subordinate recounted. ${ }^{605}$

Historian Roger Nye detailed the way in which Patton developed himself over the course of his career as an Army officer. Nye argued that the sudden appearance of military greatness found in a few officers like Patton in such a short span of time in the early 1940s when conditions were not exactly propitious for the education and training of military men was due to their own volition: those who achieved greatness did so by studying their profession outside of established professional military schools. Patton, a celebrated, energized, and profane man of action, who was not commonly perceived of as a deep thinker, was actually one of the most cerebral, well-read, and studious professionals amongst his contemporaries. He became the Army's household scholar, of sorts. As evidence, Patton left behind perhaps the most complete record of exhaustive professional study of his peers or of any general in modern U.S. military history. Over the course of his life, Patton acquired and used a personal library of books for almost daily study and reference of the martial profession. He employed a system of marginal notes and file cards to organize his thinking about tactics, strategy, leadership, and military organization from which he generated a preponderance of lectures, staff papers, journal articles, letters of instruction, diaries, poetry, and of course the manuscript for his

${ }^{604}$ Morningstar, 259.

${ }^{605}$ Semmes, 186. 
book War As I Knew It. Not only did Patton use his collection of books to develop himself, his personal library is now located at the U.S. Military Academy at West Point, New York which remains available for cadets and officers there to use to develop themselves as Patton did. ${ }^{606}$

Patton's story also formed portions of the Army's official "canon" of readings on the profession of arms, if there is such a thing. Periodically, the Army Chief of Staff releases a professional reading list intended to aid in the development of Army leaders at all levels. For example, in General Odierno's 2012, 2013, and 2014 lists, Patton appears more than once. First, in Supplying War: Logistics from Wallenstein to Patton, the author pointed out the reasons why the study of logistics is so important. ${ }^{607}$ Most battlefield results would not have been possible without the careful organization and allocation of logistical recourses and leaders who fail to consider logistics in all of their plans and operations "do so at their peril." 19 Stars: A Study in Military Character and Leadership also made the list, a book which examined Patton among others as a means for new officers to better understand the fundamentals of leadership and preparation. ${ }^{608}$

The Army used Patton extensively to illustrate several key aspects of its leadership model as seen in its capstone manual on the topic. During the process of transforming civilians into warriors, the Army does not waste time in invoking this notable leader. In their military science studies, college students in the Reserve Officer Training Corps (ROTC) are given a homework assignment to write a short essay and deliver a presentation that analyzes the adaptive leadership qualities of a selected leader.

\footnotetext{
${ }^{606}$ Nye, ix-x.

${ }^{607}$ Martin Van Creveld, Supplying War: Logistics from Wallenstein to Patton (Cambridge, New York: Cambridge University Press, 2004).

${ }^{608}$ Edgar F. Puryear, Nineteen Stars (Washington, D.C.: Coiner Publications, 1971).
} 
One of the choices is General Patton, described in the student handout as a U.S.

commander during World War II who distinguished himself in Africa, Sicily, and the liberation of France, especially during the Battle of the Bulge. ${ }^{609}$

There can hardly be a better example. According to Axelrod, in the eyes of the institution and many of its members, "Patton stands high among all other commanders as an example of leadership." Patton was a master of motivation: he inspired his soldiers to perform beyond what they conceived as their utmost. He had the unique ability to enable his subordinates to create an image of victory and the capacity to impart on them the will and the mindset to realize that image. Patton had the most intangible aspect of leadership, charisma, "which can be admired, marveled at, and even, to an extent, conveyed, but it cannot be taught." He had the uncanny ability to think like an army and had a sense of what was possible on a battlefield. His contemporaries could not conceive his methods and Patton could not understand what it was like for them to lack the intuition "that was part of his very being." Even today, military leaders as well as those in business and civil government study Patton's speeches, maxims, and other pronouncements on leadership to learn something of his motivational technique. ${ }^{610}$

\section{Doctrinal Legacy}

Forty-six years after Patton's death, as coalition forces readied to attack Saddam Hussein's army during Operation Desert Storm, in the Allied headquarters staff officers attached a large sign on the wall emblazoned with the summation of the Patton method for waging war in a single sentence: "Hold 'em by the nose and kick 'em in the ass -

\footnotetext{
609 "MSL 201 Leadership and Decision Making Lesson 06: Adaptive Leaders in History ROTC Writing Program Homework Assignment: Written Essay and Briefing," ed. Army ROTC (March 31, 2018).

${ }^{610}$ Axelrod, Patton: A Biography, 181-82.
} 
General George S. Patton, Jr.” Many of the soldiers and officers who read those words knew how Patton taught himself this fundamental principle over the course of a fortyyear career. ${ }^{611}$ As every good commander must also be an able teacher, with Patton's gift for aphorism, he had a didactic influence on generations of soldiers, some of whom planned and led an attack on Iraqi military forces that invaded Kuwait. Such succinct bits of advice such as this one, or "a pint of sweat saves a gallon of blood," reminded service members that they still operated in an organization that remained under the partial shadow of Patton. ${ }^{612}$

The art of leadership was not the only domain in which Patton influenced the Army. He also affected doctrine, the Army's guide to action rather than a set of fixed rules. Doctrine is an expression of how military forces contribute to campaigns, major operations, battles, and engagements, and in each of these arenas Patton's presence was felt in subsequent generations, at times more so than in others. Regardless, the fingerprints he left are distinguishable.

According to at least one scholar, Patton was "a true military professional working amongst craftsmen." ${ }^{\prime 613}$ Whereas Eisenhower and Bradley operated within the norms and customs of their trades, Patton mastered his craft while remaining unrestrained by its doctrine. While he believed in the archaic notions of the romantic warrior, he was also paradoxically a modernist whose methods contradicted traditional philosophies and practices. His way of waging war left many conventional critics confounded. The postWorld War II conflict of personalities and the jockeying of generals to dictate narratives

\footnotetext{
${ }^{611}$ Nye, 161.

${ }^{612}$ Patton, Harkins, and Patton, xiv.

${ }^{613}$ Samuel P. Huntington, The Soldier and the State: The Theory and Politics of Civil-Military Relations (Cambridge, Mass.: Belknap Press, 1985), 8.
} 
about their contributions compounded a very real lack of understanding of Patton's unorthodox techniques. In the years after Patton's death, developers of Army doctrine embraced increasingly industrial models of established methods of attritional warfare built on well-planned and controlled operations, published and encoded within doctrinal manuals that advocated an aim for military operations to pursue and destroy enemy forces. Conversely, Patton sought to destroy the enemy's will, often times avoiding battle altogether. He developed a unique formula for war: fire to enable maneuver; maneuver to create shock; shock to frustrate enemy decision-making; frustrate decision makers to destroy enemy morale; and destroy morale to collapse the enemy's will. As a testament to his willingness to cast aside the status quo, he committed the ultimate taboo for the Army: Patton sought to break the Army's focus and reliance upon infantry forces. ${ }^{614}$

Yet, Patton's tactical vision for maneuver and combined-arms warfare suffused the post-World War II U.S. Army even as some generals attempted to diminish it. When the army built its first postwar tank, the M46, it was named for Patton. So were the next three main battle tanks, the M47, M48, and M60. No other individual's name was used to identify an Army tank more than once. The spirit of maneuver warfare and the use of combined arms as taught by Patton, including the use of airpower, became hallmarks of Army war-fighting doctrine. After Vietnam, Army leaders turned to the foundations laid by Patton at the Desert Training Center, and in an attempt to shake the "Vietnam Syndrome" resurrected the old training ground with a program intended to ensure another Vietnam would never happen again. ${ }^{615}$

\footnotetext{
${ }^{614}$ Morningstar, 3-4.

${ }^{615}$ Axelrod, Patton: A Biography, viii.
} 
Contrary to popular perception, Patton was an amazingly broad-minded commander to whom "no other branch of service was inferior, no new weapon was alien, no new doctrine repugnant. Emotionally rooted in the history of war and the anachronous chivalry of bygone centuries, he avidly adopted all the novel mechanical wonders that burst onto the battlefields straight from the pages of H.G. Wells." ${ }^{" 616}$ If no new weapon was alien, neither were old ones. Patton illustrated his proclivity for analyzing weapons and their use on a modern battlefield early in his career. He reminded the Army not to cling nostalgically to outmoded weapon systems, but to apply them to new modalities. ${ }^{617}$

The Army sent Lieutenant George Patton to compete in the first ever modern pentathlon during the 1912 Olympics in Stockholm, Sweden. The modern pentathlon was a version of the original Greek competition in which 43 soldier-athletes vied against each other in five events: a 300-meter swim, a 25-meter pistol shoot, a 4,000 meter foot race, fencing, and riding a 5,000-meter steeplechase. Forced to develop his own training program, Patton had only two months to prepare. He ate raw steak and salad and focused on his two weakest events, running and swimming. On the voyage by ship he ran two miles every morning around the deck, practiced pistol shooting off the stern, and swam in place with a rope tied around his waist in a 20 -foot long canvas pool.

Patton performed admirably in the international competition. He finished sixth in the swimming event, third in fencing, third in the steeplechase, third in the foot race, but a dismal $21^{\text {st }}$ in the pistol shoot due to a ten-point penalty for appearing to shoot fewer rounds than required - he arguably shot one bullet through an existing hole on the paper

${ }^{616}$ Farago, Patton: Ordeal and Triumph, 687.

${ }^{617}$ Axelrod, Patton: A Biography, 178. 
target. During practice, he scored 197 out of 200 points, a world record at the time, so the two bullets through one hole theory is entirely plausible. Even so, Patton finished fifth overall, narrowly missing the bronze medal.

During the fencing matches, Patton's "slashing, give-no-quarter," aggressive attacking style made him an instant favorite. Although never having been tutored by an expert like his competitors, he defeated 20 of his 29 opponents. Intent on perfecting his skills, Patton inquired as to whom the best fencing teacher was and after the games went to the French Cavalry School in Saumur in order to take a two-week crash course from France's best instructor, Adjutant M. Cléry. After this experience, he wrote a report on his findings that received the attention of the Army's highest-ranking officers and was published in the Army and Navy Journal. ${ }^{618}$

A year later, the Army allowed Patton to go back to Saumur to study for the entire summer but he had to fund the trip personally. While there, Patton not only became an expert swordsman but an effective teacher. He lobbied the Army to add a master swordsman instructor at the Mounted Service School (equivalent to today's Maneuver Captain's Career Course). After graduating from Saumur, Patton became the U.S. Army's first Master of the Sword and the only person in history to be so named. He was assigned to Fort Riley both as a student and an instructor, and in an odd twist was the only graduate ever to sign his diploma both as a student and an instructor.

Patton was busy at Fort Riley. Not only did he attend the required classes as a student and teach three classes each week in swordsmanship, he also designed a new cavalry saber for the Ordnance Department and had a prototype made based on those

${ }^{618}$ Lieutenant George S. Patton, "Report to The Adjutant General, U.S. Army," in The George S. Patton Papers (Library of Congress, September 19, 1912). 
used by French cavalry troopers. Actually not a saber at all, it had a straight, doubleedged blade of a sword. In Saumur, Patton perfected the technique of the thrust and realized that it allowed the attacker to pierce his opponent from a greater distance. The saber, by contrast with its curved blade, was used in a hacking motion like an axe. This gave his design a marked advantage. The Ordnance Department accepted the design. In doing so, Patton, merely a young second lieutenant, rethought and redesigned an existing weapon to be more effective and adapted its purpose in a way that saved the weapon from being expunged from the Army's weapon inventory, at least for a few more years. Patton also wrote the drill regulations for his new saber, designed a qualification course for its use, and created a swordsmanship badge that could be worn if the trooper scored expert. ${ }^{619}$ In 1916, Patton wrote an article defending the use of the saber, which the Cavalry Journal published. ${ }^{620}$ From 1913 to 1918 , the Springfield Armory manufactured over 35,000 "Patton Sabers" which the Ordnance Department issued to cavalry troopers. These model 1913 sabers were the last sabers ever issued to U.S. soldiers. Although never used in combat, many were cut into sections to make fighting knives for soldiers in World War II.

During World War I, after Patton became the commandant of the first U.S. Tank School at Langres, France and later as a tank battalion and brigade commander, he set himself to understanding as completely as he could the intricacies of the FT-17 Renault light tank. He spent several weeks at the French tank school at Chamlieu soaking up as much information as he could about maintenance and tactics. He learned to drive and fire

\footnotetext{
619 "Saber Exercise," ed. War Department (Washington, DC: Government Printing Office, 1914). ${ }^{620}$ George S. Patton, "The Present Saber: It's Form and the Use for Which It Was Designed," Cavalry Journal, April (1917).
} 
the tanks and spent much time in the maintenance shops to determine what logistical support the tanks required. Patton wrote a fifty-eight page report on the new weapon system that included incredibly specific details of the vehicle. ${ }^{621}$ Patton also searched for a solution to the communications problems with his tanks. He "began experiments by installing a fishing pole for an antenna. Then he teamed up with Colonel Ralph I. Sasse and developed a coaxial mount for the tank's cannon and machine gun to enable the gunners to train the two weapons on the same target." However the initiatives did not work - the tanks' hulls made communication reception impossible for the radios of the age and the Ordinance Branch in D.C. turned down his coaxial design. ${ }^{622}$ At least for a while. Tanks of future wars all featured coax machineguns and radio antennas, both original ideas of Patton. Similarly, Patton described his ideal tank in his diary titled "Desirable Features in Proposed Tank." In it, he envisioned a tank with an improved suspension, motor, hull, armament, and speed. ${ }^{623} \mathrm{~J}$. Walter Christie, an innovative engineer, created just that with the M1919 prototype, the "Christie" tank. Although neither the downsizing Army nor the public during the interwar years were initially interested in any new developments in tank warfare, all the features Patton called for were later instituted. Tanks, Patton cautioned, would become the dominant weapon in future wars, although his contemporaries were loath to admit it even on the eve of World War II. ${ }^{624}$

Although he transitioned back to the cavalry branch after returning home from World War I, Patton continued to follow and study military modernization and write

\footnotetext{
621 "Light Tanks," in Patton Archives (The General George Patton Museum, December 12, 1917).

${ }^{622}$ Farago, Patton: Ordeal and Triumph, 99.

${ }^{623}$ Patton, "Patton Diary." May 9, 1945, Box 3, in The George S. Patton Papers (Library of Congress).

624 "Tanks in Future Wars," Cavalry Journal (May 1920).
} 
about his theories, often published in the Cavalry Journal. In January 1924, the journal featured Patton's treatise on the use of armored cars in cavalry operations. ${ }^{625}$ Patton busied himself by writing new pistol regulations in 1928 while working in the Office of the Chief of Cavalry. ${ }^{626}$ In 1930, the Cavalry Journal published Patton's report on a cavalry division maneuver exercise held the year prior in which Patton discussed the effective use of armored cars, the $37 \mathrm{~mm}$ field gun, machine guns and rifles, airplanes, and artillery along with notes on tactics. In 1934 while at the Army War College, he wrote a paper titled "Some Notes on the Effect of Weapons and Means of Communication on Tactics" in which he traced the evolution on how weapons and communication played important roles in the development of new tactics from Frederick the Great, Napoleon, the American Civil War, the Austro-Prussian War of 1866, Boer Wars, Russo-Japanese War, and World War I. ${ }^{627}$

Patton bequeathed to the American military tradition a new definition of professionalism in the profession of arms, one that included a keen understanding of the actual use and utility of arms. Patton was not only a master of tank doctrine and tactics: he thoroughly understood everything about the weapons at his disposal and insisted that commanders also became masters of detail as he did his entire career. However, attaining that level of technical proficiency is increasingly difficult as technology on the battlefield becomes more complex..$^{628}$

\footnotetext{
625 "Armored Cars with Cavalry," Cavalry Journal (1924).

${ }^{626}$ Farago, Patton: Ordeal and Triumph, 109.

${ }^{627}$ George S. Patton, "Some Notes on the Effect of Weapons and Means of Communication," in Patton Archives (The General George Patton Museum, 1934).

${ }^{628}$ Axelrod, Patton: A Biography, 177.
} 
With Schwarzkopf's end run in Operation Desert Storm and the invasion of Iraq in 2003 returned much of Patton's "hold 'em by the nose and kick 'em in the ass" routine he developed with his combined arms technique in which he integrated armor, infantry, artillery, and air support in each of his major World War II operations. This combined arms approach to warfare came only after years of theorization, trial, and outright disregard of traditionalist doctrine. Although not adopted officially by the Army until well after his death, this approach became a large part of Patton's legacy for the Army. In effect, his doctrine and teachings spawned from an updating of the cavalry idea, much like his rethinking of weapon systems: instead of clinging nostalgically to an outmoded weapon system, he salvaged what was best from the system and applied it to a new modality.

Patton was more than just a tank proponent. He was an innovative exponent of combined-arms theory and may be the key contributor of a doctrine that is today considered common knowledge. His early advocacy of tank and infantry cooperation in World War I led to his embrace of rapid and accurate artillery fire, motorized logistical support, and air-ground liaison in order to provide tactical air support. ${ }^{629}$ Decades of contemplation, reflection, and practice produced a lethal combat formation tailor-made to conduct rapid, successive, and sustained shock on an enemy force. ${ }^{630}$

Beginning with his treatise "Light Tanks," Patton drafted a distinctive doctrine in which armored forces fought in two phases: first, with cooperation with infantry to break enemy lines and second, to assume a role traditionally held by cavalry, that of pursuit. ${ }^{631}$

\footnotetext{
${ }^{629}$ Higgins, 108-11.

${ }^{630}$ Morningstar, 55.

${ }^{631}$ George S. Patton, "Subject: Light Tanks," in George S. Patton, Jr. Papers (Library of Congress, December 12, 1917).
} 
In his "Brief Notes on the Tactical Employment of Tanks," Patton called for armor to lead infantry forces, rather than the other way around, and conduct pursuit after dislodging the enemy - an idea that he further fleshed out in a paper titled "Light Tanks in Exploitation." ${ }^{932}$ Meanwhile, traditionalists in the War Department thought of tanks as nothing more than a mobile machinegun firing position that supported infantry. Patton envisioned a much greater role, which he detailed in "Further Notes on the Use of Tanks in Various Operations Including Open Warfare.” In this he called for tanks to attack with simultaneous bursts of artillery fire as infantry followed tanks in echelons. ${ }^{633}$ Patton noted the difficulties of coordination between infantry, artillery, and armor and called for a change in organization that would enable the exploitation of opportunity. ${ }^{634}$ Patton's "Original Tank Report. The Basis of the U.S. Tank Corps" served as the foundation for subsequent tank development in the American Expeditionary Force (AEF), and at least one of his recommendations, a proposal that tanks be organized into platoons of five tanks, with three platoons to a company and three tank companies to a battalion, survived as part of American tank organization until the early 1980s. ${ }^{635}$

In an essay written in 1922, perhaps the first formal incarnation of Patton's combined arms doctrine, Patton rejected tactics based upon overwhelming artillery and the futility of trench warfare, promoting instead that dismounted firepower be used "as pivots of maneuver, that is, to use their fire to pin the enemy to the ground" while

\footnotetext{
632 "Brief Notes on the Tactical Employment of Tanks," in Patton Archives (General George Patton Museum); "Light Tanks in Exploitation," in Patton Archives (General George Patton Museum).

633 "Further Notes on the Use of Tanks in Various Operations Including Open Warfare," in Patton Archives (General George Patton Museum).

${ }^{634}$ Patton and Blumenson, The Patton Papers, 1, 604.

${ }^{635}$ Dale Wilson, Treat 'em Rough: The Birth of American Armor, 1917-20 (Novato, CA: Presidio, 1989), 17; Patton, "Subject: Light Tanks."
} 
mounted elements used their mobility to attack the flanks or rear of the enemy so held. ${ }^{636}$ However, although persuasive, it was no match for the pervasive influence of infantry traditionalists. After completing post-World War I reviews, the Army issued Field Service Regulations 1923, which ensured the centrality of the infantry and the relegation of all other arms to infantry support for the next sixteen years. ${ }^{637}$

As the Third Reich's blitzkrieg tore across Europe over a decade later, Patton watched with attentive eyes. He was privy to Military Intelligence Division bulletins that remarked on the effectiveness of the German's combined arms formations. He understood that the German method of combining tanks, mechanized or motorized infantry, and close air support kept with the German tradition of making war - that of seeking a decisive battle early in a campaign. However, Patton differed in one main respect: he disagreed with the German reliance upon tank-heavy spearheads and instead preferred a more balanced combination of arms with armored divisions distributed amongst corps in order to enable agility and flexibility. When France fell, Patton joined a select group of officers brought together in the basement of a high school in Alexandria, Louisiana during the pre-World War II maneuvers to draft recommendations for creating an American version of the German's panzer formation. The result was a call for the creation of combined arms tank divisions. ${ }^{638}$

Patton was perfectly poised to submit well-considered recommendations, many of his recent ideas being a result of his experiences in the pre-World War II maneuvers the Army conducted in the Southern states. The key point from the maneuvers was that

\footnotetext{
636 "What the War Did for Cavalry," Cavalry Journal (April 1922) in Province, Military Essays and Articles by George S. Patton, Jr. 1885-1945.

${ }^{637}$ Field Service Regulations, ed. War Department (1923), 11.

${ }^{638}$ Morningstar, 72-73.
} 
rather than abide by the rules laid out by umpires, Patton created a combined arms battle drill that was ultimately more effective against anti-tank guns, and it was the anti-tank field gun that infantry traditionalists preferred over the extensive use of armor advocated by proponents like Patton. By using artillery and close air support as well as dismounted troops to fix the enemy in place, bold flanking maneuvers by tanks became possible, as was pursuit. ${ }^{639}$ As a result of the pummeling Patton handed his opponents during the war games, in May 1941 the Army published FM 100-5 Operations in which "The armored division is organized primarily to perform missions that require great mobility and firepower. It is given decisive missions. ${ }^{, 640}$ However, it was a modest win for armor advocates. The infantry was again given primacy on the battlefield.

As Patton demonstrated its utility and effectiveness during combat, his combined arms theory began to take traction. Never one to take counsel of his fears, Patton was certainly unafraid to test new ideas, such as increasing the number of air liaison officers with ground troops three times the allowed number. Slowly, units across the Army began to adopt Patton's techniques. ${ }^{641}$ He wrote another paper detailing his doctrine of combined arms columns with the prescription to lead with armor, fix the enemy with infantry and artillery, and flank with armor after it pulled back from initial contact. ${ }^{642}$ In another, Patton published his thoughts on how armored divisions should be organized, a significant departure from established doctrine and one that included a complete rebalance of power based on his combined arms theory: each division had equal amounts

\footnotetext{
${ }^{639}$ Letter to General Lesley McNair from George S. Patton, in The George S. Patton Papers (Library of Congress, May 27, 1941).

${ }^{640}$ Field Manual 100-5 Operations (Washington, DC: War Department, 1941), 5.

${ }^{641}$ Morningstar, 83.

642 "Use of Armored Divisions" in volume II of Patton and Blumenson, The Patton Papers, 455.
} 
of infantry, artillery, and armor and none had primacy over the other. ${ }^{643}$ While Army doctrine recommended commanders lead with infantry, bring up armor as needed and use air support as a last resort, Patton did the exact opposite. He led with armor and used tactical air support as an integrated feature of his scheme. While doctrine and traditionalists recommended fighting set-piece battles against strongpoints in order to destroy enemy forces, Patton often avoided battle, exploited enemy weaknesses, and kept the enemy off balance throughout a campaign. Doctrine sought attrition in a battle. Patton sought shock during the campaign.

Speed was of paramount importance for Patton's tactics. Using strong, coordinated forces in a bold and violent offensive was effective against a conventional enemy, as in the first Gulf War and the 2003 invasion of Iraq. However, to traditionalists, the speed and flexibility of Patton's operations were worrisome signs of a lack of command and control. Standard doctrine in 1941 instructed commanders to "make circumstance bend to plans - to bring order out of chaos." Patton believed that execution of deliberate tactics was more important than deliberate plans: his maxim was to fight the fight, not to fight the plan. He issued simple, flexible instructions that relied on adjustments based on leaders' initiative. Patton's emphasis on subordinate judgments during execution was unfathomable to his peers who were schooled in contemporary infantry doctrine marked by an abundance of control measures (such as phase lines, boundaries, sectors and direction of fires, etc.) in battle. To them, Patton's methods of planning looked sloppy and lazy. Bradley called Patton's methods “impetuous," and bemoaned that "Patton did not give a damn about details," but when results contradicted

643 "Notes on Combat Armored Divisions" in Military Essays and Articles. 
these impressions, critics could only express bewilderment. ${ }^{644}$ Many who could not comprehend Patton's methods believed he had some sort of "inexplicable divine star guiding his operations" or that he had some sort of clairvoyance or intuition. None of these mystic beliefs were true, of course. Patton's lifetime of study provided him "with unique insights divergent from doctrine and therefore inscrutable to his peers and to many later historians." 645

Eisenhower and Bradley failed to see opportunities and their inflexibility caused them to execute plans without a focus on defeating the enemy. Although Patton was often relegated to subservient roles, his initiative and insight made gains and headlines. ${ }^{646}$ Arguably, nearly every one of Bradley's successes during the war was directly attributable to Patton but Bradley just could not seem to give credit where it was due. Take, for example, Operation Cobra, the plan to break out from the Normandy hedgerows after the D-Day invasion. Opus Number One, the first in a series of bold and brilliant, albeit relatively unknown, plans Patton devised during 1944 stands out as one of the great designs of World War II. It was never officially recognized or adopted and it could not stave off the disastrous battle in the Normandy hedgerows. But it did become the inspiration for Operation Cobra, for which Bradley gladly received all praise. This plan illustrated Patton in a role, that of strategic thinker, of which he is still not widely recognized. It showed that this complex general who was regarded merely as a tactical genius was equally talented as a planner with a fascinating strategic flair and vision. ${ }^{647}$

\footnotetext{
${ }^{644}$ Bradley and Finkelstein, 355; Omar N. Bradley and Clay Blair, A General's Life (New York: Simon and Schuster, 1983), 199.

${ }^{645}$ Morningstar, 6-7. See also Nye; "Whence Patton's Military Genius?," Parameters 21, no. 4 (December 1991).

${ }^{646}$ Farago, Patton: Ordeal and Triumph, 482-83.

${ }^{647}$ Ibid., 429-31.
} 
Even if Bradley or Eisenhower could not admit it, a few individuals at the time recognized that Patton "was no mere hell-for-leather tank commander but a profound and thoughtful military student. ${ }^{\text {"648 }}$ As Bradley put it after the war when, conveniently for him, Patton was unable to defend his own honor, "Without meaning to detract from his extraordinary achievements, Patton's great and dramatic gains, beginning in Sicily and continuing through Brittany and on across the Seine at Mantes, Melun and Troyes, had been against little or no opposition." Bradley, ever the traditionalist, never understood, or had the tools to comprehend, that this was by Patton's design and only made possible by his unique understanding of combined arms columns. ${ }^{649}$ The teetotaler general with the self-crafted "G.I. General" image (which was just as unrealistic as Patton's self-created brand) just could not get over the fact that the boisterous man he considered "indifferent to supply, lacking self-discipline, and essentially lucky" could become a legend. ${ }^{650}$ And so, Eisenhower, Montgomery, and Bradley, the three men remaining alive and whom carried out this "war of the generals" over who should get credit for essentially winning the war, actively discredited the Patton legend, distorting the picture of Patton and his methods. ${ }^{651}$

The way in which Patton's tactics played out on the operational level also provides useful examples for students of mobile warfare. As Historian John Rickard noted regarding the Battle of the Bulge, Patton's conduct remains relevant for senior commanders to study. Patton's command technique that encompassed the human factor offers timeless instruction and his operational technique can still serve the modern

\footnotetext{
${ }^{648}$ Quoted from a New York Times article in ibid., 831.

${ }^{649}$ Morningstar, 87.

${ }^{650}$ Bradley, 51-52.

${ }^{651}$ Morningstar, 8-9.
} 
practitioner of maneuver warfare. Patton updated his situational awareness and strove to disrupt German intentions using an estimation process combined with clear communication of his intent to his subordinates, shaping the conduct of operations and the ultimate outcome of the battle. Patton's overall effectiveness as an army commander during the Bulge was a major source of American success, which arguably could have otherwise ended in catastrophe. Furthermore, his command technique and proclivity to be seen at the front inspired those who followed him. ${ }^{652}$

Patton's tactics became his strategy, a fact lost on his contemporaries: they could not comprehend his operations, much less see how his methods affected the big picture. Yet, although the Army did not appreciate Patton's techniques immediately, by 1991 and again in 2003, the Army employed ground advances in the Middle East that had echoes of Patton's campaigns. Admittedly, Patton's tactics were better suited for vast battlefield spaces occupied by large conventional armies and are not applicable in asymmetrical warfare scenarios, which diminished Patton's doctrinal influence since 2003 and earlier during the Vietnam years with the realities of limited warfare. ${ }^{653}$ Doctrine changes, of course, but the Patton legacy eventually did have an effect.

As noted, postwar developments shrouded Patton's legacy. A cultural shift occurred from the championing of warrior generals to a want for diplomatic types such as Eisenhower, Bradley, and Joe Collins. With the number one champion of doctrinal change buried in Luxembourg, traditionalists took the opportunity to reinstate traditional infantry-artillery-based attrition doctrine in Korea and Vietnam and shunted aside Patton's theory of war. A series of unexpected events led to the resurrection of Patton's

${ }^{652}$ Rickard, Advance and Destroy: Patton as Commander in the Bulge, 303.

${ }^{653}$ Axelrod, Patton: A Biography, 176-77. 
methods encoded in “AirLand Battle" doctrine, in which Patton's ideas finally gained favor in U.S. Army doctrine. ${ }^{654}$

Patton's influence took root initially at Fort Knox, the traditional home of the U.S. Armor School. While there, Creighton Abrams, a Patton acolyte, sowed seeds that helped institutionalize many of Patton's tactical methods. But the war in Korea created difficulties for the Army with its existing doctrine. With the new corporate Army culture and its premium on agreeable officers, the practice of career attrition returned with General Mathew Ridgeway at the expense of maneuver and its offensive spirit, inverting Patton's achievement. Rather than using fire to achieve maneuver, the Army reaffirmed its dedication to using maneuver to enable fires. Armor once again had no operational or strategic role. Where once Patton used infantry to open holes for decisive combined arms drives, now, as before, tanks only supported infantry and all Patton disciples became marginalized. The stalemate in Korea may have been the result. During most of the Cold War, the doctrinal focus was on strategic defense, attrition through firepower, limited objectives, and restricted initiative - practices with limitations that came to light later in Southeast Asia during the Vietnam War. Limited objectives and defense rarely brings with it overwhelming successes, but did bring a stagnant front in Vietnam cultivated by detrimental doctrinal practices. The Army continued to value precise and detailed planning with a heavy emphasis on command and control - symbolized by commanders in helicopters directing units from above the battlefield. ${ }^{655}$

The corporate management attitude that infused the Army, in part due to Eisenhower's emphasis on team play and his postwar legacy of developing politically

\footnotetext{
${ }^{654}$ Morningstar, 18.

${ }^{655}$ Ibid., 251, 53, 56-57.
} 
attuned generals, was a trend taken to a higher level by Secretary of Defense Robert McNamara. During Vietnam, political aversion to casualties stifled any desire for maneuver and offense. The belief that higher casualties are a necessary byproduct of offensive operations is an illusion of the short term. Patton argued that maneuver reduced casualties and brought victory, an argument grounded on empirical evidence when controlling for units assigned to Patton's Third Army for the entirety of the war in mainland Europe, Patton took more ground, cities, and prisoners and killed more enemy troops and destroyed more equipment all while sustaining fewer casualties than any other army. ${ }^{656}$ It is both ironic and tragic that McNamara and the other "Whiz Kids" could not come to that conclusion before losing tens of thousands of American soldiers with a futile doctrine. McNamara and his crew could not see that "the link between morale and maneuver became clear in Vietnam," an aspect of warfare that Patton thoroughly understood. ${ }^{657}$

When General Creighton Abrams, who served as an armored battalion commander in the $4^{\text {th }}$ Armored Division under Patton in World War II, became elevated to the position of Chief of Staff of the Army in 1972, he faced the challenge of a doctrine that was still focused exclusively on infantry-centered combat and counterinsurgency efforts in Vietnam. FM 100-5 stressed defense and deterrence and asserted the purpose of U.S. military forces was to create an environment of order: there was no mention of grasping opportunity out of chaos; chaos was the enemy. In fact, the manual did not

\footnotetext{
656"G-1 Section 12th Army Group: Report on Operations (Final After Action Report) Volume 2," (National Archives and Records Administration II). Box 1314, Record Group 407.

${ }^{657}$ Morningstar, 257-258.
} 
mention victory at all. ${ }^{658}$ Tasked with fixing an Army in disarray after years of being sidetracked in Vietnam and with the Soviet Union's massive conventional forces looming, Abrams united all branch schools in 1973 with the creation of the U.S. Army Training and Doctrine Command (TRADOC). General William E. DePuy, a company commander who earned a Distinguished Service Cross while serving under Patton in World War II, became TRADOC's first Commanding General and carried with him Patton's ideas and legacy of tough and realistic training. As a division commander in Vietnam, DePuy had a dispute with the Army Chief of Staff, General Harold K. Johnson, over the development of officers as he set out to erase the corporate management culture in the officer corps and reinstall the principles of leadership, initiative, and offensive spirit. ${ }^{659}$ DePuy's tendency to replace poor performing officers (after given a chance to redeem themselves, of course) mirrored that of Patton during his time as $2 \mathrm{~d}$ Armored Division Commander and at the Desert Training Center in 1941. General Don Starry, the Armor Branch Chief at the time of the DePuy-Johnson disagreement, delivered 162 recommendations to Abrams and DePuy for reforming the Army, which included "transforming the U.S. Army into an organization that could fight and defeat modern, combined arms mechanized forces quickly anywhere in the world." ${ }^{960}$ This was clearly in conflict with existing infantry-centric doctrine.

DePuy preached that tanks were to get into enemy rear areas, echoing Patton's tactical emphasis. He also reiterated Patton's views on combined arms tactics,

\footnotetext{
${ }^{658}$ Field Manual 100-5 Operations of the Army Forces in the Field, (Washington, DC: Department of the Army, 1968), 1-6.

${ }^{659}$ Henry G. Gole, General William E. DePuy: Preparing the Army for Modern War (Lexington: University Press of Kentucky 2008), 189-97.

${ }^{660}$ Paul H. Herbert, Deciding What Has to Be Done: General William E. DePuy and the 1976 Edition of Field Manual 100-5 Operations (Fort Leavenworth, KS: U.S. Army Command and General Staff College, 1988), 30-32.
} 
coordinated close air support, an emphasis on intelligence gathering, simplicity in plans and orders, and subordinate initiative at the lowest levels of command. ${ }^{661} \mathrm{He}$ believed in avoiding enemy strengths and exploiting enemy weaknesses, which had much in common with Patton's ideals. ${ }^{62}$ With Abram's support, DePuy set out to do a total rewrite of Army doctrine, a feat he accomplished in eighteen months. He chose Starry and the Armor School to take the lead, ultimately using the armor branch to drag the infantry into the mechanized domain. ${ }^{663}$

During discussions between the Armor and Infantry Schools about the draft doctrine, disagreement arose, with the infantry arguing for static battlefield lines with reinforced antitank and missile positions in strongpoints, a throwback idea of the preWorld War II Army. The result was a compromise in the form of the 1976 version of FM 100-5 Operations. In it was a doctrine called Active Defense that carefully prescribed tactics on how to use terrain to canalize the enemy, the use of killing zones for massed fire, and described how to use combined arms, maximize battlefield intelligence collection, and suppress enemy fires. This version confronted the prime strategic problem the Army faced: how to fight an enemy force numerically superior on a predominantly tank battlefield. For Patton strategists, the new FM 100-5 "had too much explanation of how to hold the enemy by the nose with massed fires and had too little discussion on how to kick them in the ass with maneuver." Yet, the context within which thinkers conceived the doctrine was one of political currents that shaped tactics with

661 "Implications of the Middle East War" and "Infantry Fighting Positions" in Richard M. Swain, ed. Selected Papers of General William E. DePuy (Fort Leavenworth, KS: U.S. Army Command and General Staff College, 1973), 35, 86-87.

${ }^{662}$ Herbert, 35.

${ }^{663}$ Morningstar, 266; Swain, 86; Herbert, 35. 
strong defensive themes, such as the 1973 Yom Kippur War. It stressed firepower and a more modest maneuver doctrine. ${ }^{664}$ Unfortunately, the manual focused on tactics, not on operating campaigns. Strategic vision was by then a strictly national-level consideration that stressed maneuver predominantly in terms of moving combat capabilities to deliver firepower or to increase combat power. Using maneuver to strike at the enemy's will to fight was not even a consideration, which was fine as far as it went, but did not quite go far enough for prescribers of the Patton doctrine. ${ }^{665}$

The debate raged amongst doctrinal thinkers in the 1970s and 1980s. Criticism of the 1976 version of FM 100-5 led to another phase of doctrine reform when Starry replaced DePuy as commander of TRADOC. Chief among the critiques was that "Active Defense" overemphasized defense and firepower and marginalized maneuver. The debate centered around whether or not forces should or should not meet the enemy head on but be allowed to penetrate and engage infantry defenses while armor maneuvered to the enemy's rear, attacking supply, communication, and command and control elements. ${ }^{666}$ This would be more in tune with Patton's ideas that he implemented during the Battle of the Bulge, but still missed his use of maneuverability to create a series of shocks that paralyzed the enemy's ability to react and defeated his will to continue. ${ }^{667}$

By the late 1970s another evolution of thinking set in, prompted in part by the debate over Active Defense as well as new tactical concepts and concerns. The result was the 1982 FM 100-5 that introduced AirLand Battle doctrine, which called for using

\footnotetext{
${ }^{664}$ Susan Canedy John L. Romjue, and Anne W. Chapman, Prepare the Army for War: A Historical Overview of the Army Training and Doctrine Command 1973-1993 (Fort Monroe, VA: TRADOC, 1993), 53.

${ }^{665}$ Morningstar, 267-68.

${ }^{666}$ John L. Romjue, 54.

${ }^{667}$ Morningstar, 268.
} 
airpower to find and attack follow-on enemy echelons in order to disrupt enemy attacks in depth, throw off the enemy's timetable, and prevent defeat during initial battles. The new manual embraced a reliance on subordinate initiative, tactical and operational offensives as part of a strategic defense, surprise counterattacks aimed at weak spots, and the moral dimensions of war. It finally emphasized maneuver and the fundamentals of war, grounded on the intellectual patrimony of classic military theorists. ${ }^{668}$ Patton may not have been cited, per se, but his influence in the new doctrine was clear. Initiative, offense, attack weakness not strength, leadership, training, air-ground cooperation, and operational art: these were the tenets of Patton's way of war and became official Army Doctrine. Notable in this doctrinal development was the addressing of the morale dimension of war: Patton's attack on the enemy's spirit. ${ }^{669}$ This version of FM 100-5 was a repudiation of the attrition warfare that dominated warfare theorists in the U.S. Army for decades. Through Abrams and those he influenced, such as DePuy and Starry, Patton's aggressive spirit, with his use of an integrated combined arms team, including a tank-heavy armored force, became the key component of the intangible dimension of war described within the doctrine that eventually emerged ${ }^{670}$ With the new version, the continued movement to seize opportunities and destroy the enemy's coherence was a unique way in which the doctrine channeled Patton. DePuy, ever the Patton disciple, believed that General George S. Patton, Jr. would be pleased to know that maneuver doctrine finally took hold in the U.S. Army of the 1980 s. ${ }^{671}$

\footnotetext{
${ }^{668}$ John L. Romjue, 55-57.

${ }^{669}$ Heidi Toffler and Alvin Toffler, War and Antiwar: Making Sense of Today's Global Chaos (London: Warner Books, 1993), 66.

${ }^{670}$ Orr Kelly, King of the Killing Zone (New York: W.W. Norton, 1989), 240.

671 "Towards a Balanced Doctrine," in Swain, 315.
} 
However, there was one key difference between Patton's operational method and AirLand Battle: the use of tactical air support. Whereas AirLand Battle relied heavily on airpower to disrupt the enemy in depth and prevent his concentration at the decisive place and time on the battlefield, Patton, with General Otto Weyland's XIX Tactical Air Command, developed unprecedented air-ground cooperation for a different purpose. The new doctrine mirrored Eisenhower's use of airpower in Normandy to block possible German reinforcements. Patton used airpower to cover his flanks and the areas directly forward of his advancing columns. ${ }^{672}$

In 1986 the Army released an updated version of FM 100-5 that contained five references to Patton sprinkled throughout the volume. Under "Major Operations Planning" was a reference to Patton during the Battle of the Bulge. A section on "Deception" mentioned Patton's role in Operation Fortitude, the plan that deceived the Germans as to the true location of the Normandy landings. In "Lines of Operation," the manual discussed the failure to support Patton and exploit the Third Army's success for a decisive drive to the German border. And on page 122 the manual cited Patton's definition of the difference between haste and speed. Yet perhaps most striking was this passage:

\footnotetext{
Audacity has always been a feature of successful offenses. More attacks have been defeated because of a lack of audacity than for any other reason. To the overly cautious around him, General George S. Patton, Jr., warned 'Never take counsel of your fears. The enemy is more worried than you are. Numerical superiority, while useful, is not vital to successful offensive action. The fact that you are attacking induces the enemy to believe that you are stronger than he is.' In short, the key tenets of AirLand Battle doctrine - initiative, agility, depth, and synchronization - also apply to any successful attack. ${ }^{673}$
}

${ }^{672}$ Morningstar, 270.

${ }^{673}$ Field Manual 100-5 Operations, (Washington, DC: Department of the Army, 1986), 86. 
General Wesley Clark noted later the spirit of maneuver warfare, and the use of combined arms, including airpower as taught by Patton, ultimately became hallmarks of army war-fighting doctrine. ${ }^{674}$ The Army finally accepted many of the principles of Patton's way of war, but key tenets of his methods eluded doctrinal legitimacy. Besides the example given previously in regards to the use of tactical air support, the new doctrine placed a reliance on synchronization, which implied detailed, top-down planning and control, a requirement of decisive battle. Patton looked for flexibility and relied on subordinate leader initiative. Patton's G-3 Operations cell could not keep pace with changing conditions if attempting detailed, synchronized plans. With few exceptions, on any battlefield where Patton operated commanders who paused to plan ceded the initiative to the enemy: mechanized warfare was far too fluid. Patton wanted leaders to develop the situation and recognize and respond to fleeting opportunities using intelligence and malleable command and control. Patton sought to develop an Army that found opportunity in chaos rather than attempting to create order. Moreover, Patton sought to avoid battle, to shock the enemy with unexpected and threatening maneuver, and to repeat such shocks as to overwhelm the enemy's ability to react effectively and thus erode his morale and break his will. Although it was a step closer to Patton's way of making war, these aspects were not exactly verbatim in AirLand Battle doctrine. ${ }^{675}$

During Desert Storm, shades of Patton crept into battle plans. On February 24, 1991, the $1^{\text {st }}$ Marine Expeditionary Force, along with an Army tank brigade, was supposed to hold the enemy in place, a fixing operation according to military operational terms, while two Army corps conducted a deep, rapid envelopment maneuver referred to

\footnotetext{
${ }^{674}$ Axelrod, Patton: A Biography, viii.
}

${ }^{675}$ Morningstar, 271-72. 
as the "Hail Mary." On the operational level it was a "hold them by the nose and kick them in the ass" maneuver. The fixing operation encountered less resistance than anticipated and pushed on through Kuwait City. The bold flanking maneuver went well ahead of schedule. Miraculously, Coalition forces sustained just over 100 casualties as they destroyed Iraqi communication capabilities, took the initiative, struck deep, prevented the enemy's backup echelons from reinforcing, integrated air, land, and sea operations, avoided frontal attack against strong points, and knew what the enemy was doing, all while preventing Iraqi intelligence from knowing what was going on. This emphasis on frustrating enemy reactions by keeping them off balance like a boxer who keeps his opponent against the ropes reflected the core of Patton's doctrine. The influence of Patton on officers such as Abrams, DePuy, Starry, and even Generals Max Thurman and Colin Powell came to fruition on the battlefield if not in doctrinal manuals.

Even the Patton persona, that carefully crafted image, made something of a return in the style of General Norman Schwarzkopf, nicknamed "Stormin' Norman." But, mirroring the differences between Patton's principles and the latest version of FM 100-5, there were differences between AirLand Battle practiced in the Gulf War and Patton's way of war. For example, Patton would have likely taken issue with Schwarzkopf's intent to destroy enemy forces, not just attack, damage, or surround. Instead, based on knowledge of his actions during the race across France in World War II, Patton probably would have sought decisive maneuver to defeat the enemy - to crush his will to fight through a campaign to create series of sustained and repeated shocks. Schwarzkopf sought destruction by envelopment: his plan was in essence a recreation of World War II German operational maneuver to develop a decisive battle. Schwarzkopf's plan used 
maneuver to bring overwhelming firepower on the enemy. General Tommy Franks, the ground commander during Desert Storm, ordered his troops to halt, refuel, and reform to achieve mass. It was a noticeable pause, one that Patton undoubtedly would not have taken.

Despite these differences, the Gulf War marked a monumental shift from the dogmatic infantry-based doctrine of massed fires and attrition embraced in previous American wars. Abrams, DePuy, and Starry partly resurrected the Patton ideal, resulting in a new doctrine that was as close to pure Patton as these devotees could manage, and demonstrated in Desert Storm where a shift in mindset was the most obvious. The U.S. Army finally went on the offensive. And as historian James Morningstar noted in his seminal work Patton's Way, "There was Patton's spirit manifested." It was again the American way of war, and Patton would have been proud. ${ }^{676}$

Unfortunately for Patton's legacy, Patton's methods in AirLand Battle enjoyed only a brief renaissance. With the end of the Cold War and an overwhelming victory in Desert Storm, the Army became overconfident. New global threats and challenges eroded the impact Patton had on doctrine in many ways. During the years following the Gulf War in 1991, the Army began to move away from Patton's principles embedded in AirLand Battle doctrine and a new generation of Army leaders facing new challenges around the world and at home searched for new solutions. The focus switched, first to intervention and peacekeeping operations with minimal objectives and with smaller expeditionary forces in places like Somalia, Haiti, and Bosnia. Finally, with the rise of global terrorism, the Army's doctrinal emphasis was to counter terrorists and insurgents.

${ }^{676}$ Ibid., 274-76. 
The first departure began in June 1993 when the Army issued a new edition of FM 100-5 that stopped using the term AirLand Battle, although it did maintain certain aspects of that doctrine. The new manual emphasized joint operations, the integration of advanced technology, and "operations other than war." And to add insult to injury, the new manual mentioned Patton only once: as an example of failure to plan and arrange logistics. ${ }^{677}$

However, the 2003 invasion of Iraq had echoes of Patton's way of warfare. General Tommy Franks, who led the ground invasion, set out to break Iraqis' will to resist by attacking their morale, although there were problems. Shock and awe failed as concerns to avoid collateral damage stymied commanders' operations. Targets located in noncombatant population centers forced planners to shift their focus elsewhere. In order for shock to work, it must convey a real threat, which requires demonstrated lethality. Paradoxically, the more precise airpower is, the less effective it is on defeating the population's morale. The presence of rampaging armor columns in the enemy's rear area, on the other hand, proved effective in undermining the enemy's will to fight. ${ }^{678}$ But emerging technologies intended to enhance subordinate initiative, such as the blue force tracker, a tool that allowed commanders to view on a computer screen the location of all subordinate commands, had the unintended side effect of creating reliance upon those tools. Subordinate commanders' initiative was relegated to high-tech intelligence sources, which, although quicker than intelligence gathering mechanisms used in past wars, were still unable to keep up with the high rate of advance. The speed and continuity of the decision making process became compromised.

${ }^{677}$ Ibid., 276-78; Field Manual 100-5 Operations, (Washington, DC: Department of the Army, 1993), 6-8. ${ }^{678}$ Morningstar, 278-79. 
Additionally, Patton's movements were unpredictable to the Wehrmacht, yet the rapid advance in Iraq was linear and therefore predictable - its axis of advance allowed Iraqi leaders to simply sidestep the onslaught and change their strategy. Part of that strategy was to disappear rather than surrender. The resulting "de-Ba'athification" effort to removed $\mathrm{Ba}$ 'ath Party members from positions of influence after the war was eerily similar to the failed denazification program in post-World War II Germany. A chaotic patchwork of insurgents, guerrillas, criminals, and terrorists arose to carry on the resistance that the Iraqi military found futile. The answer the Army came up with was a return to Vietnam-era doctrinal tactics: search and destroy missions against elusive opponents who slipped in and out of civilian populations with ease, all within the context of a larger nation-building effort. Frustrations arose as did comparisons to the quagmire in Vietnam. Outdated doctrine reemerged as military leaders attempted to bring order out of chaos in the absence of better ideas. ${ }^{679}$ Then, in 2004 military historian Victor Davis Hanson presented a lecture entitled "What Would Patton Say About the Present War?" Hanson argued that Patton would recognize it as a war on Islamic fascists and would see the need for aid and reconstruction. Patton would attack the enemy's morale and will and would make certain that he defeated the terrorists and their supporters "in such damaging fashion that none in the Middle East might find such a repugnant cause at all romantic, bringing it as it did utter ruin as the wage of the wrath of the United States. ${ }^{\prime 680}$

But Patton was dead and his legacy nearly forgotten during the War on Terror. Nary had a commander heeded Hanson's harking to the past. After several years in the

\footnotetext{
${ }^{679}$ Morningstar, 279.

${ }^{680}$ Victor Davis Hanson, "What Would Patton Say About the Present War?," Imprimis 33, no. 10 (October 2004).
} 
wars in Afghanistan and Iraq, the Army adopted organizational changes that sacrificed flexibility in order to gain more units on the ground (but with fewer actual troops) for counterinsurgency operations. The Army shifted back to square divisions of four brigades that only fielded two maneuver battalions each. In recent years, the attempt to go back to triangle divisions (divisions with three brigades of three maneuver battalions) after a review of the reorganized brigades' shortcomings, have been incomplete and hampered by budget limitations. Doctrine reflected these organizational changes. General David Petraeus spearheaded an effort to produce the new FM 3-25 Counterinsurgency (COIN) in 2007, which codified a doctrine that espoused several elements of Patton's doctrinal legacy. COIN doctrine encouraged subordinate initiative, flexibility in approach, rapid decision-making, an emphasis on intelligence, and a focus on the enemy's will rather than his physical destruction. However, COIN took a more defensive posture, lacked an emphasis on maneuver, and had no discussion of advantageous positions. Where Patton emphasized tactical killing to enable decisive operational maneuver, the new COIN doctrine emphasized winning popular support rather than killing the enemy at the tactical level. Patton connected maneuver to shock, shock to frustrate enemy decision cycles, frustration to undermine morale, and undermined morale to defeat enemy will. The counterinsurgency doctrine focused on winning popular support to deny sustenance to insurgents. ${ }^{681}$ The two methods could hardly be more different.

The 2005 Base Realignment and Closure Commission took a major step in dismantling the Patton legacy as it pertained to an insular armor identity when it closed

${ }^{681}$ Field Manual 3-25 Counterinsurgency, (Washington, DC: Department of the Army, 2007). 
the Armor Center at Fort Knox, Kentucky, and moved the schoolhouse to Fort Benning, Georgia in 2011. Until then, the War Department deliberately kept separate the Chief of Cavalry at Fort Riley, Kansas (and later the Armor Chief at Fort Knox) from the Chief of Infantry at Fort Benning in order for the branches to develop independently and to realize armor's full potential. This deliberate action was completely undone with the recent move. Although some historians and members of the Armor Branch asserted that this separation was essential in both keeping Patton's doctrine alive after World War II and enabling the eventual development of the AirLand Battle doctrine, they misunderstood one of Patton's key concerns, that of combined arms operations. One of Patton's many misgivings about Army doctrine was the inability for tankers and infantry to cooperate on the battlefield, something that could only be accomplished through realistic training. "In an armored unit, as in an infantry division, attacks must be coordinated; and the infantry, and the tanks, and the [artillery] guns must work as a unit." ${ }^{982}$ Patton probably would have wanted the artillery school to relocate as well. Naysayers argued "the Army submerged the entire armor branch into a Maneuver Center of Excellence based at the home of the infantry.... Tankers understandably felt betrayed and saddened." $" 683$ However, this is a misread of Patton's doctrinal influence and his insistence upon combined-arms cooperation and training. After all, Patton never spent more than two days at Fort Knox but his meteoric rise began at Fort Benning in 1941 when he took command of an armor brigade and then the $2^{\text {nd }}$ Armored Division.

\footnotetext{
682 "Letter of Instruction No. 3," 20 May 1944 in Province, Military Essays and Articles by George S. Patton, Jr. 1885-1945.

${ }^{683}$ Morningstar, 281-82.
} 
In March 2012, Benjamin Patton, the grandson of the late general and author of Growing Up Patton, posted an editorial on the Huffington Post website titled, "What Would General Patton Do in Iraq and Afghanistan?" in which he concluded that the general would follow one of his own maxims: "Weapons change, but the man who uses them changes not at all. To win battles, you do not beat weapons, you beat the soul of the enemy." " 684 Michael Keene, author of Blood, Guts, and Prayer, indicated in another editorial with a title asking the same type question, "What Would Patton Do?," that rather than poring over the writings of T.E. Lawrence, General David Petraeus should "have been reading the war journal of America's greatest combat general, George S. Patton, Jr." If he had, Petraeus would have learned that Patton would not have disbanded the Iraqi army but rather used them to help maintain order much like he did in Morocco with the Vichy French legions he bested in November $1942 .{ }^{685}$

Patton tailored his way of war to the particular circumstances of conventional land warfare on a large scale, not counterinsurgency with limited objectives. His methods might apply against ISIS ground units, but such forces constantly change as they adapt to threats against them. With the defeat of their conventional forces, the enemy transformed into guerrilla forces using terrorist operations as evidenced in Iraq during the War on Terror. However, just because Patton's ideas might not apply to current operational environments does not mean the Army should return to the same infantry-centric attrition doctrine. The legacy Patton left for the Army in regards to doctrine was a revolutionary approach to conventional warfare. ${ }^{686}$ And with emerging threats from Russia, China,

\footnotetext{
${ }^{684}$ Ben Patton, "What Would General Patton Do in Iraq and Afghanistan?," www.huffingtonpost.com/benpatton/general-patton-iraq-afghanistan_b_1371117.html.

${ }^{685}$ Michael Keane, "What Would Patton Do?," www.theblaze.com/contributions/what-would-patton-do.

${ }^{686}$ Morningstar, 283.
} 
Iran, and North Korea, all with large conventional forces, the revivification of that legacy may be necessary yet again.

In a profession that is not particularly known for developing deep thinkers, much less appreciating cerebral types, Patton long served the Army as a kind of house intellectual. For him, the past provided avenues of approach to the future and his careful study of others' experiences offered invaluable guidance to latter-day problems. ${ }^{67}$ While he definitely had a lasting impact on doctrinal developments, his legacy did not immediately take hold nor did the Army adopt Patton's methods in toto. But there remain strains of his practice and thinking in the way the Army conducts war today. No mere tactician, Patton was a true professional: he was one of the few theoreticians and innovators of the "warrior poet" mold that the modern U.S. Army produced. And perhaps in a bit of irony, it was a friend of his and a former subordinate who greatly benefited from Patton's influence but who actively discredited the Patton legend. During the "war between the generals," Eisenhower and Bradley removed Patton acolytes or avatars from any position of influence. As a result, over time the Army produced generations of generals more steeped in politics than waging war as the World War II generation fought over who should receive blame and credit for combat operations. For decades, the Army found itself mired in conflict over both warfare doctrine and legacies. Patton figured prominently in both and continues to do so today ${ }^{688}$

In a fitting gesture that symbolized the passing of the torch to those who embraced the Patton legacy, Beatrice selected for War As I Knew It a dedication that included Patton's favorite quote, taken from John Bunyan's Pilgrim's Progress. It reads:

${ }^{687}$ Patton, Harkins, and Patton, xiii.

${ }^{688}$ Morningstar, 227. 
"My sword I give to him that shall succeed me in my pilgrimage, and my courage and skill to him that can get it. My works and scars I carry with me, to be a witness for me that I have fought His battles who now will be my rewarder. So he passed over and all the trumpets sounded for him on the other side. ${ }^{" 689}$ Although there were several doctrinal developments over the years in response to changing threats, fortunately for the Army, if the United States finds itself at war with a near-peer adversary in the future, there is evidence of remnants of the Patton collective memory within the Army's ranks. The lessons of the icon that personified mobile warfare in its finest American version may be of use again by those who choose to carry the torch. Hopefully, dusting off Patton's old playbook will be enough to help future generations of Army soldiers and officers win our nation's wars.

${ }^{689}$ D'Este, 820. 


\section{PART 2}

\section{USING THE LEGEND}

\section{CHAPTER VIII}

\section{THE ARMY COLLECTIVE AND SUBCULTURE}

The greatest privilege of citizenship is to be able to freely bear arms under one's country's flag. General George S. Patton, Jr.

I am a soldier. I fight where I am told and I win where I fight. General George S. Patton, Jr.

Thus far, the preceding chapters addressed the roles Patton, biographies, histories, monuments, landmarks, movies, museums, commemorations, magazine articles, and other forms of public memory played in the creation and perpetuation of the Patton legend, or the collective memory. Additionally, the previous chapter detailed a distinct legacy Patton left for the U.S. Army. The remainder of this study examines the relationship between that collective memory and legacy and an institution's obligation to remember. ${ }^{690}$ Although it is simple to take for granted the status of the Army as a unique subculture, the idea warrants further exploration. There is a requirement for certain collectives to be immersed in specific memories, to keep those memories alive in the context of a particular subculture, and to pass them on from generation to generation. Memories form part of collective's heritage, a term used to describe properties that descend to heirs. Those cultural markers that constitute a group's sense of identity are

\footnotetext{
${ }^{690}$ Irwin-Zarecka, 25.
} 
passed much like an inheritance and are bounded by tradition that requires structures that enable the passing of those markers. The collective, those who identify with others through communal bonds, common goals and objectives, and distinct visions of a shared past, are the topic of Part 2. The past offers a great deal of comfort, inspiration, and essential anchoring points for concepts of the self and the group. Identity in the collective is paramount for its capacity to remember its past. ${ }^{691}$ This particularly holds true for the institution from which Patton drew his primary identity: the United States Army.

Collectives remember and remembrance, in turn, helps form the collective. Take, for instance, World War II memorialization in places such as Washington, D.C. Many remaining veterans of that war take a pilgrimage to the capital's monument and while there not only do they recall the past but share their stories with current members of the military along with those who also served in the war. In times of crises there is an urgent need for national unification, and so is the case when we recall perilous times: Americans desire to be reminded of how much we can do when we work together rather than fight amongst ourselves. However, public memory is a double-edged sword: it can be a device used to foster unity and pride in a collective or can be used as a tool to create discord. It emerges from the intersection of official and vernacular cultural expressions. Official views originate in the concern of cultural leaders or authorities at all levels of society, especially in government and military bureaucracies. These leaders share a common interest in social unity, the continuity of existing institutions, and loyalty to the status quo, and they attempt to advance their concerns by promoting interpretations of past and

\footnotetext{
${ }^{691}$ Phillips, 2.
} 
present realities that reduce the power of competing interests that appear to threaten the attainment of their goals. Rather than using complex or ambiguous terms, they restate reality in terms of ideals, both in timelessness and sacredness. "Official" culture promotes a nationalistic, patriotic self-concept of the whole that mediates an assortment of interests. The memory of Patton is no stranger to this tactic, which was, as shown in the case of the movie Patton, caught up in a political attempt to drive patriotism and an individual's personal interest (Bradley) to garner recognition. In contrast, an array of specialized interests are characterized by motivations that are diverse and changing, reformulated from time to time by the creation of new social units. Defenders of subcultures are numerous and intent on protecting values and viewpoints of reality based on firsthand experiential knowledge, rather than in "imagined communities" like that of a large nation. Ironically, it is these expressions that convey what social reality feels like rather than what it should be like. ${ }^{692}$

How people attend to the past and how they make sense of it is initially very much grounded in experience. The transformational experience of soldiers as they suppress their civilian identity markers and take on those of their new subculture makes the presence of the past all but impossible for them to ignore. In fact, the past that is told and retold need not be real or true to offer the basis for communal solidarity. Active remembrance is all that is required, but it must be seen as communally shared and deemed important for the community's self-definition and identity. Rituals and the cyclic practice of them function very well to that end. ${ }^{693}$ Memories constitute societies and in daily actions, rituals, and exchanges, societies reaffirm these memories. Collectives,

${ }^{692}$ Gillis, 75 .

${ }^{693}$ Irwin-Zarecka, 57. 
therefore, are made by memories and make memories. But memories are open to contest, revision, and rejections. Memory is a highly rhetorical process. Those who maintain a sense of collectivity and togetherness are deeply implicated in persuasive activities and in the underlying assumptions and experiences upon which the collective builds meaning and reason. There should be a constant concern for how memories attain meaning and become public. ${ }^{694}$

The collective is a term often used casually, but without communal bonds and the sense of a shared past, it does not fit. Those attitudes within large populations, such as the whole of humanity, nationality, or even generations, are difficult to gauge. For students of local and regional identities and traditions, the concept of a collective is more applicable. For any group, it is easy to assume too much as to the relevance of both the past and meditations on it. At its very base, memories can serve as a nexus for a community: those who shared an experience and created a bond may eventually extend those ties to others who derive meaning from the experience even though they were not part of the original experience. Personal relevance of the memory, not personal witness, begins to define the community. The connection between experience and remembrance becomes severed then redrawn to capture the effects of that experience beyond individual memories, transcending time and often, space. But a wider population, as in the case with Patton, sometimes absorb communities of memory. It was nearly impossible to separate the public and military's collective memory of Patton in the early stages of this study. They both shared a similar trajectory and influenced each other. The memory work done by stakeholders of the Patton collective memory extended to the public at

${ }^{694}$ Phillips, 3. 
large, although it was and is more acute within the confines of the Army subculture. Without some form of common historical narrative to partner with all the patriotic symbolism it entails, the state cannot achieve legitimacy as a political entity any more than can military organizations. The Army's answer to cohere historical narratives into a usable story, and thereby establish its venerability, was the creation of a deliberate historical program to ensure the fostering of esprit de corps that forms a sense of a shared past reciprocated through remembrance rituals. ${ }^{695}$

Generations are not primary communities of remembrance, although they do pass on more than just the records of past experiences or monuments to their heroes. They also leave changes in the cultural landscape. But their size, internal diversity, and geographical spread may lead one to overestimate when addressing the collective memory of an entire generation, even within the confines of a nation. The past informs but does not define individual lives. ${ }^{696}$ However, there are instances in smaller groups where generations can become communities of memory, constituting a much more manageable sample. For example, veterans and the military community have an organizational framework for remembering Patton while the general public does not. Therefore, generations within the Army may provide a valid framework for future study when trying to understand the collective memory of Patton. Without the sharing of memories it is difficult, if not impossible, to conceive of social bonding or cohesion. In Western culture, "communities cohere around the formation of a civic domain, and their history unfolds according to its maintenance." ${ }^{967}$ When acted upon, collective memory

\footnotetext{
${ }^{695}$ Irwin-Zarecka, 47-53, 61.

${ }^{696}$ Ibid., $54-55$.

${ }^{697}$ Phillips, 191.
} 
becomes a socially constructed discourse that helps form a social group, or collective. As culturally specific beliefs about an historical event merge with individual memories and take on visible and legible form, such as with monuments or other types of concrete memory projects, collective memory emerges as a construct of the political, social, and economic structures that conditions, and perhaps determines, the production of those forms. ${ }^{698}$

The utilization of an amalgamation of sociological theories that provide a framework for the arguments presented and viewing the Army as a unique subcultural collective is helpful to understand how this phenomenon occurs. To start, ideas about identity are salient to the study of collective memory when thinking about the past as a galvanizing force for a collective. The root meaning of the word identity comes from the Latin idem, meaning sameness. In its adjectival form the word retains that meaning, which is "identical." For many sociologists, identity means an affinity or membership in a commonality or collective, such as class, gender, or nation. ${ }^{699}$ For the purposes of this study, both ideals are germane. For institutions such as the Army, a certain degree of sameness is a sought-after and valued commodity, especially in combat units that rely heavily upon a tight-knit social fabric. Sameness within a collective is important, at least when it pertains to the belief in and adherence to shared assumptions, beliefs, and cultural norms. As it relates to memory, the act of remembering bolsters a sense of belonging and a sense of sameness, and how people or events are remembered are shaped by an assumed identity. Of course, identity and memory change over time. They are not fixed representations or constructs of reality, nor are they objective phenomena. People

${ }^{698}$ Gillis, 186.

${ }^{699}$ Schofield, 205. 
constantly revise memories to suit current identities and both of these help them make sense of their place in the world. ${ }^{700}$ As a collective symbol, memory (or heritage) must be accepted by those inside the collective and may be inaccessible to outsiders. As opposed to history, whose data are scientific and whose premises are accepted by reasoning, memory can be social and subjective and often accepted on faith. Memory defies empirical analysis and is defined by mystery, fantasy, invention, and error. ${ }^{701}$ Identity has several characteristics that inform its importance to how collective memory works. First, it has criteria of being linguistic and cultural. ${ }^{702}$ For example, in a seminal study on the public use of history, researchers noted that American men who served during World War II are three times more likely than younger men to report a high level of importance on U.S. history than their personal or family pasts due to the shaping nature of that experience. ${ }^{703}$ The bonds created during their time in service held strong over time, especially given the grasp that the military subculture has on members, both present and past, coupled with such a traumatizing experience. In Western social theory, the attributes of cohesion, continuity, uniqueness, and homogeneity ascribed to persons transcribe to collectives. ${ }^{704}$ Heritage, or how collectives pass on their interpretation of the past, is the union of memory and tradition. That which we inherit is integral to our being. Heritage has the ability to distill the past into icons and symbols and embraces things and ideas that give a collective its identity. It reflects shared values and interests,

\footnotetext{
700 Gillis, 3.

701 Ibid., 49.

${ }^{702}$ Schofield, 206.

${ }^{703}$ Roy and David Thelen Rosenzweig, The Presence of the Past: Popular Uses of History in American Life (New York, NY: Columbia University Press, 1998), 131.

${ }^{704}$ Gillis, 33.
} 
forges identity, and buttresses self-esteem and social cohesion by inventing a distinctive legacy. ${ }^{705}$

Group identity in the military is characterized in part by exclusivity, particularly in the combat arms. Part of that exclusiveness is wrapped up in a heritage that differentiates the collective from others, a category of people who treasure most those characteristics that set them apart. Were a collective open to others it would forfeit the value of heritage as an emblem of solidarity. ${ }^{706}$ The exclusive nature of a collective's heritage and identity is part of its draw for aspiring members. Heritage has similar characteristics with memory, namely in that collectives value it over history. All that matters is that individuals in the group believe something to be true, that members share the same past, and pass on to other generations what their predecessors handed them. Members of the Army potentially identify more strongly with Patton than outgroup individuals - he is not only part of the institution's heritage, he shared the same heritage as current members. For many, Patton served as an avatar for the ideal soldier. Patton's sense of self was almost exclusively tied to his self-identity as a soldier. Although he was a larger-than-life figure around which exists an extant collective memory in the public, he was first and foremost a soldier himself and soldiers today can more closely identify with him through their similar experiences. Individuals, subgroups, and nations all demand identity as if it were a necessity of life itself. Identity and memory are highly selective processes, inscriptive rather than descriptive. They can be constructs that people tend not to think about but instead are thought with. The relationship between the two is historical, the record of which can be traced through commemorations or other

\footnotetext{
705 Ibid., 43, 46.

706 Ibid., 47-49.
} 
memory work, which are by definition social and political. They involve the coordination of individual and group memories. ${ }^{707}$ As sociologist Maurice Halbwachs asserted, identity drives memory and memory drives identity. Identity, like collective memory, is an ongoing process. It surfaces during commemorations and the like, but also like memory, identity need not be actively attended to in order to exist.

Simply put, individuals and collectives use the past in order to sustain current identities, which are deeply rooted in history, language, and culture. ${ }^{708}$ Much like the search for identity, collectives have a desire for immortality, particularly for members of military groups whose jobs come with the distinct possibility of death. These collectives take steps to ensure that their past would not die with them, but that they would live on in the memories of those who they touched in life and those who later become members of the collective. ${ }^{709}$ Research into the phenomenon of identity indicates that people use experiences to address questions of meaning and meet unique needs, such as the quest for immortality, that connect them to others throughout the ages. For example, military units connect individuals to the collective and protect them from the larger world, much like families, while blending cultural traditions. People use creative and diverse ways to recognize, use, and revisit where they come from and where they are heading, about who they are and how they will be remembered, especially later in life, or in the case of military collectives, upon their death or retirement. Collectives turn to the past to build relationships and a sense of community in order to feel at home in the present tense..$^{710}$

\footnotetext{
${ }^{707}$ Ibid., 4-5.

${ }^{708}$ Schofield, 204-05.

${ }^{709}$ Rosenzweig, 60.

${ }^{710}$ Ibid., 62-63.
} 
Heritage also serves as a rallying point around which individuals and collectives identify. It is their legacy as a distinct group. However, when lauding their own legacy and excluding or discrediting those of others, collectives can commit themselves to rivalry or even conflict. ${ }^{711}$ This is particularly true for collectives like the Army whose raison d'être is the creation of violence and conflict on a battlefield, with a mission to fight and win the nation's wars. Concepts like defense or deterrence are not possible without the capacity to deal death and destruction. For this collective, rivalry and competition is as valuable as heritage, legacy, and identity. It can create competition with both allies and adversaries, which increases lethality while promoting internal esprit de corps.

All of these ideas - collective memory, history, heritage, public memory, the past, remembrance, social solidarity, reminiscence, and legends - help form culture. A collective's subculture includes knowledge, belief, art, morals, law, custom, and any other norms, or what the cultural theorist Stuart Hall called the "lived practices that enable a society or class to experience, define, interpret, and make sense of its conditions of existence."712 Cultural identity, for many, becomes more powerful over time and it has a very practical purpose for the Army. Identity, social cohesion, esprit de corps, and group pride are force multipliers, or capabilities that, when added to and employed by a combat force, significantly increases the lethality of that force and thus enhances the probability of successful mission accomplishment. The Army's history, its heroes, and icons can serve in ways other than as documentation of Army operations and campaigns or as part of a lessons learned think tank. Group identity and social solidarity are as

\footnotetext{
711 Gillis, 42.

712 Schofield, 257; Terry Eagleton, The Idea of Culture (Malden, MA: Blackwell, 2000), 34.
} 
important to the Army as training and effectiveness on the battlefield - is in fact the former that allows the U.S. Army to remain an effective organization.

Emile Durkheim's theories on social solidarity and religion have much to say about societies at large but may also be applied to collectives. As he put it, the "study of solidarity lies within the domain of sociology" and cannot be merely explained with historical methods. Nor can solidarity be explained through a study of an individual, although individuals certainly come into play in his theory. ${ }^{713}$ A sociological theory, therefore, must be used as a framework to understand the phenomenon of solidarity: Durkheim's theory provides such a framework when distilled to smaller groups of people. While using Durkheim's theories of social solidarity and religious life to analyze a subgroup or subculture on a scale smaller than an entire society or the context of the nation-state, it is necessary to substitute "society" and other broad terms for cohesive groups with terms such as "organization," "institution," "collective," "subculture," "group," and the like. Although Durkheim concerned himself with much wider swaths of the population, this study utilizes the same theories to analyze a unique, albeit quite large (the Army has nearly one million members), organization. Equating religion and the military is erroneous, to be sure, and there are vast differences, but it is useful to apply broad theoretical concepts regarding one institution to another to gain insights into how collectives form.

For Durkheim, the collective conscious is a state of mind amongst a group, or what he called a "moral community." ${ }^{.714}$ Humans are by nature social beings. Durkheim

\footnotetext{
${ }^{713}$ Emile Durkheim and Steven Lukes, ed. Emile Durkheim: The Division of Labor in Society (New York: Free Press, 2014), 54.

${ }^{714}$ Emile Durkheim and Karen E. Fields, The Elementary Forms of Religious Life (New York: Free Press, 1995), xlvii.
} 
differed from other sociologists, such as Karl Marx who believed that as society progressed, humans became alienated from their means of production and each other. Rather, Durkheim asserted that with a highly specialized workforce and mode of production, society became less fragmented and saw an increase of organic social solidarity and cohesion as a consequence of capitalism. The concepts of the individual or individualism are not major concerns here, although Durkheim certainly attempted to reconcile how individuals kept their sense of individualism in a social system that maintained order through regulation and discipline. An integral question that Durkheim addressed was what held societies together, given that people become more unlike each other as specialization and the division of labor increases over time. How is it possible that individuals become more autonomous while simultaneously becoming more dependent upon and linked to society? His answer was that a new type of solidarity emerged out of simple societies as they progressed towards a more complex world. ${ }^{715}$ In his Preface to the Second Edition (1902) of The Division of Labor in Society, Durkheim addressed professional organizations. By illuminating the division of labor in the military, the Army touts the "Profession of Arms" - a legitimizing rhetorical tool designed to recognize the advanced state of the Army today. As Durkheim succinctly stated, thousands of individuals spend most of their time in an industrial and commercial environment. In the Army, soldiers and officers spend nearly all of their time in an immersive subculture. Furthermore, Durkheim asserted, "Society cannot exist without cohesion and regulation." ${ }^{, 716}$ Not only does the military place individuals in unique living conditions within close proximity to other members of the group, perhaps no other

\footnotetext{
${ }^{715}$ Durkheim and Lukes, xiv-xvi.
}

${ }^{716}$ Ibid., 10-11. 
professional organization can exemplify Durkheim's ideas quite like the military, which has deliberate mechanisms to socialize its members into a cohesive collective. And, as some literature on the topic suggests, task cohesion (a shared belief in an organization's mission) and social cohesiveness (the ability to get along) are often included as prime characteristics of effective organizations. ${ }^{717}$

If it is impossible, as Durkheim claimed, for people who to live together in such close proximity to not develop some sense of a shared identity, then military service provides a unique example for understanding this phenomenon. ${ }^{718}$ Members become attached to the organization, its interests become their interests, and members' behavior changes accordingly. This solidarity contributes to the strength of the group. When individuals in commonality have the same interests, they defend those interests and enjoy the company of one another. It is a sort of artificial kinship that members enter into readily and freely and has all the effects of natural kinship. ${ }^{719}$ The "band of brothers" ideal becomes a reality, not merely an imaginary existence. Durkheim expanded upon cohesive groups, asserting that it is common knowledge that people are drawn to things that resemble themselves and to people who think and feel similarly. Deep, complimentary friendships come from membership in these types of groups as people find qualities in others that they themselves lack.

\footnotetext{
${ }^{717}$ Alice H. Eagly, "When Passionate Advocates Meet Research on Diversity, Does the Honest Broker Stand a Chance?," Journal of Social Issues 72, no. 1 (2016); Robert J. and William M. Hix MacCoun, "Unit Cohesion and Military Performance," in Sexual Orientation and U.S. Military Personnel Policy: An Update of RAND's 1993 Study (Santa Monica, CA: RAND Corporation, 2010), 141; H. van Dijk, M.L. van Engen, and D. van Knippenberg, "Defying Conventional Wisdom: A Meta-Analytical Examination of the Differences Between Demographic and Job-related Diversity Relationships with Performance," Organizational Behavior and Human Decision Processes, 119 (2012).

${ }^{718}$ Durkheim and Lukes, 18.

${ }^{719}$ Ibid., 18-19.
} 
The basic argument that Durkheim made in regards to social solidarity (an effect of the division of labor) is that with a rise in specialization, members of an organization rely upon each other and must communicate in order to accomplish organizational goals. It has a moral, or social, character since these organizations require order, harmony, and cohesion. To measure social bonds, Durkheim used laws as visible symbols as evidence of the maintenance of relationships between close-knit members of a society. Because solidarity and cohesion are intangibles that are difficult to observe, to study these social outcomes one must find external manifestations of it. Law, he continued, represents the main forms of social solidarity by codifying norms that a group deems important enough to punish if violated.

Durkheim analyzed the different types of solidarity through different classifications of law. Societies force individuals to obey rules, which they see as indispensable in maintaining good order and adherence to social norms established by the community. These laws prescribe certain obligations, to be sure, but also regularize punishments based on violations as well. In true dialectical form, he stated that societies "do not condemn [violations of the law] because it is a crime, but it is a crime because [societies] condemn it." Those with legitimate authority enforce and codify rules and ensure respect for beliefs, traditions, and collective practices and defend the collective consciousness from all enemies, within and without. ${ }^{720}$ Coincidentally, there is an explicit example of this for members of the military, who are sworn to protect the Constitution of the United States against all enemies, foreign and domestic. Rules, regulations, and laws are the embodiment of the collective will and those with the ability

\footnotetext{
${ }^{720}$ Ibid., 45-46, 52-54, 64-66.
} 
to enforce them have that authority granted by the collective consciousness of individuals.

The United States Army has its own particular set of rules and regulations. Although Durkheim examined the collective consciousness of the nation-state, his theory of mechanical solidarity applies to sub-groups as well. Organizations of all types have bylaws, codified rules, and expectations for behavior. The Army is no different, perhaps even providing a unique example of how Durkheim's theory applies. While soldiers and officers must adhere to local, state, and federal laws like any other citizen of the United States, there are additional sets of laws, rules, and regulations that apply only to military personnel. The Uniform Code of Military Justice (UCMJ) is a set of rules of behavior based on established and accepted norms in the Army subculture and are enforceable much like laws. Furthermore, the Code of Conduct, Army Values, and a series of Army Regulations designed to regulate everything from dress and appearance, behavior between superiors and subordinates, and customs and courtesies provide evidence of how this subgroup exemplifies Durkheim's theory of social solidarity based on its manifestation through law. Punishment for violating the collective's rules can be severe, including a general discharge from the group based on a failure to adapt or align culturally with its norms and regulations - one may be expelled from the collective for not properly socializing into the subculture. Mechanical solidarity, the type of solidarity that penal law symbolizes, or rules that prescribe punishment, is the expression of the most essential social assimilations. Social solidarity arises from states of consciousness 
that are common to all members of the same collective - a shared sense of values represented by repressive law. ${ }^{721}$

Besides mechanical solidarity, organic solidarity also exemplifies the collective consciousness of groups. Unlike mechanical solidarity, which is evidenced through prescribed punishments due to violations of laws, regulations, or other codified forms of social norms, organic solidarity is more "charitable," as Durkheim argued. For individuals to guarantee the rights of one another, there must exist a mutual respect that makes them "cling to one another and to the single society of which they form a part.",722 In other words, organic solidarity is the willing dedication that individuals have for each other. While the Army enforces its collective consciousness through the UCMJ, it also relies upon mechanisms that promote organic solidarity. While individuals constitute the collective because they resemble one another (as the Army's regulation of behavior, dress, and appearance enforces), the Army, and particular subgroups within the larger organization, also recognizes differences between its members. Organic solidarity theory assumes this fact. Assimilating into the collective consciousness or dominant culture denotes mechanical solidarity, but Durkheim suggested an even stronger representation of solidarity when individual specialists work within a particular sphere and the collective recognizes parts of individual consciousness and the value those individuals bring to the group. Some sociologists concede that the division of labor attributes to an openness to innovative thinking and alternative perspectives, even if there is still resistance from "well-entrenched cultural assumptions linked to not questioning orders, plans and ideas,"

${ }^{721}$ Ibid., $81,84$.

722 Ibid., 95 . 
particularly from superior officers. ${ }^{723}$ The more extensive this "free area" where the appreciation of value-added characteristics resides, Durkheim stated, the stronger the cohesion that arises from organic solidarity. Society, or collectives like the Army, becomes more effective as it becomes increasingly specialized. ${ }^{724}$ In today's parlance, this may be understand as cognitive diversity.

The more "primitive" societies are, Durkheim argued, the more resemblances there are between individual members - a characteristic of mechanical solidarity. ${ }^{725}$ While it is true that in the example of the modern Army, where "beliefs and practices are clear-cut," leaving less room for individual divergences, there is a duality of solidarity in the collective. In many instances, the Army does not rely solely upon the "uniform mold" in which it casts its members, creating as near a perfect form of collective consciousness that can exist. ${ }^{726}$ Therefore, a paradox exists when using Durkheim's ideas on the division of labor to denote solidarity. The reality of the modern Army is one of solidarity built upon both mechanical solidarity and a division of labor as well, an organic solidarity brought out of the collection of smaller spheres of influence that rely upon and appreciate the roles of others in the subculture. ${ }^{727}$

At the same time, the beliefs and practices that symbolize the collective consciousness of the Army do not assume "less and less religious a character," nor does

\footnotetext{
${ }^{723}$ Remi M. Hajjar, "Emergent Postmodern U.S. Military Culture," Armed Forces and Society 40, no. 1 (2013): 131. See also Gregory Fontenot, "Seeing Red: Creating a Red-Team Capability for the Blue Force," Military Review (September 2005) and Remi M. Hajjar, "A New Angle on the U.S. Military's Emphasis on Developing Cross-Cultural Competence: Connecting In-Ranks' Cultural Diversity to CrossCultural Competence," Armed Forces and Society (January 2010).

${ }^{724}$ Durkheim and Lukes, 120.

${ }^{725}$ Ibid., 105.

${ }^{726}$ Ibid., 120.

${ }^{727}$ Whitney Pope and Barclay D. Johnson, "Inside Organic Solidarity," American Sociological Review 48, no. 5 (October 1983): 681.
} 
the institution tend to celebrate the individual over the collective. ${ }^{728}$ The links that result from similarity grow stronger, rather than weaker, in this particular example, opposed to Durkheim's assertion. Mechanical solidarity does not grow weaker and the Army certainly does not replace it with the gradual growth of organic solidarity. Quite the contrary, in fact, the Army exemplifies a strengthening of the collective consciousness through mechanical solidarity with its regulation of norms and practices as well as organic solidarity built upon the division of labor.

Although the application of Durkheim's theory of social solidarity to understanding the unique dynamics of the Army must recognize this paradox, it does not diminish the framework of how these two types of solidarity form. Understanding the Army as a subculture outside of mainstream society in which the normal rules of conduct do not and cannot apply due to its unique mission, to examine it as such requires looking through the lens of both aspects of Durkheim's theory of social solidarity. The division of labor has a profound effect on the Army and increases solidarity amongst its members while at the same time the Army relies heavily upon purposefully creating similarities amongst its members through various mechanisms relatable to Durkheim's observances of law. Meanwhile, Durkheim asserted that when the division of labor is forced, there arises a hierarchy and increasing levels of inequality, decrying this phenomenon as unnatural as societies progress. In regards to mechanical solidarity, this has little effect as "lower societies" assume this social reality - solidarity is not threatened. Hierarchies in organizations like the Army are the norm, a necessity even. Members of the group accept the hierarchy because "the whole of the inner life is bound up" with the group.

${ }^{728}$ Durkheim and Lukes, 134. 
Cohesion is sacred to them - it serves as the basis for the moral and religious order (or sociality, as Durkheim used the term). ${ }^{729}$ The organization becomes more important than the self.

Besides the UCMJ, the Code of Conduct, and Army Regulations, Durkheim's theory on religious life also provides clues regarding how the Army promotes organic and mechanical solidarity to increase cohesion. Durkheim explained that religion is a system of ideas through which people imagine their society and their relationship to it. ${ }^{730}$ By studying the "primitive" religions of Aboriginal Australians, Durkheim attempted to illustrate how religion was a fundamental and permanent feature of humanity founded by and symbolic of a particular society. Like most of his contemporaries, Durkheim was heavily influenced by Darwin's theory of evolution, which was recognizable in his handling of the earliest form of religion, totemism. For Durkheim, other religions of the world evolved to varying degrees and so he intended to apply his theory globally - other religions fulfilled the same needs, played the same role, and had the same origins, elucidating the nature of social life. ${ }^{731}$ Sociologists debated the merits and demerits of Durkheim's views vehemently. However, the religious nature of society and the use of symbols and icons that create the sense of solidarity and cohesion that religion brings are ideas about social organization that apply even in non-religious societies or organizations. Applying these concepts to the military potentially allows for a deeper understanding of this particular subculture.

\footnotetext{
${ }^{729}$ Durkheim and Lukes, 297.

${ }^{730}$ Durkheim and Fields, xix-xx.

731 Ibid., 3.
} 
Durkheim's general thesis in The Elementary Forms of Religious Life was that religion is an eminently social reality and was an exemplar he used to develop a more generalizable theory about social organization. Religious representations are expressions of collective realities; rites are enactments that assembled groups create to evoke or maintain a collective mental state. ${ }^{732}$ The combination of rites created what he termed "cults" which had two aspects: negative and positive. Negative cults were those that prohibited certain ways of acting and positive cults were those that drew people closer to the "sacred" world. ${ }^{733}$ Durkheim turned to visible features that allow for the recognition of religious phenomena, pointing to two categories; beliefs, or representations and opinions, and rites, or modes of action that define how humans interact with sacred objects. ${ }^{734}$ Groups share religious beliefs and practice corresponding rites that are accepted by and unify all members of the group. Members feel connected through common faith, a group of people that Durkheim called the "church." ${ }^{735}$ Like a church, subcultures such as the Army share connectivity through beliefs and rites and it is through these same features that the collectivity of Army members can be understood in the same terms as Durkheim's theory on religious life.

Durkheim's use of totemism, a derivative of animism and naturism, provides clues to understanding the emblematic nature of both religion and subcultures that use symbols to create solidarity. In Durkheim's case study, clans had a dominant place in collective life, which had two essential traits that characterized them: a name and a

\footnotetext{
732 Ibid., 9.

${ }^{733}$ Ibid., 303, 330.

${ }^{734}$ Ibid., 21.

${ }^{735}$ Ibid., 9, 21, 41.
} 
totem. ${ }^{736}$ As an example, the U.S. Marine Corps' sense of collectivity, pride, esprit de corps, and identity resides in its name and their symbol (totem) - the eagle, globe, and anchor emblem is widely recognizable. Members claim the status of "once a Marine, always a Marine" and each member wears the collective's symbol on their uniforms. The Army differs partly in that it is considerably larger. For the Army, the sense of collectivity is felt more within its subgroups (much like the clans that Durkheim described) although there have been recent attempts to mirror the Marine Corps with the Army's "Once a Soldier, Always a Soldier" slogan. These subgroups are typically smaller individual units that comprise the Army, such as the $101^{\text {st }}$ Airborne Division (the "Screaming Eagles"), the 82 ${ }^{\text {nd }}$ Airborne Division ("All-Americans"), and the like. Symbols are also important for these subgroups, much like the totem was for Durkheim's understanding of Aboriginal totemic religions. Admittedly, there is one major difference between the use of totems and military symbolism, that of the belief in the power of the religious totem and the representative symbol.

While the totem, like the Army's use of unit symbols, is first and foremost a name and emblem (Durkheim even listed military-type totems such as flags, coats of arms, and distinctive paintings of people and things) there is not a cognitive mystic belief of contagiousness in these symbols for Army personnel. Totemic images were real beings, in the view of believers, which were the object of rites, creatures of totemic species, and members of the clan. Military symbols are not particularly set apart as sacred, and are used in everyday life (the profane). Yet, like a totem, its symbols are worn as proof of identity with the group. For totemic religions, the totem had a religious character, and the

\footnotetext{
${ }^{736}$ Ibid., 100.
} 
sacred and profane were described in reference to the totem. Regardless, a similarity exists between totemic religions and the Army when groups use their symbols in certain rites. Respect and solemnity for the symbol is visible during the unfurling and uncasing of unit colors (flags), a "sacredness that stems from one cause: it is the material representation of the clan." Unlike religions, however, within representative symbols and the beliefs of Army subgroups there is no system of ideas that embrace the universality of the things or representations of the world as a whole, a distinctive characteristic of religion. ${ }^{737}$

Durkheim's treatment of totemic symbolism applies in part to subcultures. As he asserted, social life is only possible through vast symbolism. Sacredness is not an inherent quality in religious objects, nor is sacredness observable in a single human. ${ }^{738}$ They acquire their power when they are set apart by groups of people and only remain sacred while a collective believes there is power in them. ${ }^{739}$ As Durkheim stated, the student of sociology must know how to "reach beneath the symbol to grasp the reality it represents and that gives the symbol its true meaning." Even the most bizarre rites and myths translate some type of human need or other aspect of life. ${ }^{740}$ Often that need is a sense of connection to the past and to the group.

Perhaps Durkheim offered the best example of this phenomenon. Discussing flags as symbols, he described the feelings one has that are materialized in a connection to a concrete object. A symbol takes on emotions that are transferred to it, such as a flag. The symbol becomes the object of affinity. It is loved, feared, and respected...even

\footnotetext{
${ }^{737}$ Ibid., 108-11, 18, 24-27, 41.

${ }^{738}$ Ibid., xix, xiv.

${ }^{739}$ Ibid., xlvi.

740 Ibid., 2.
} 
something for which a member of a group is willing to sacrifice. "The soldier who dies for his flag dies for his country, but the idea of the flag is actually in the foreground of his consciousness." While a country cannot be lost due to the loss of a battle flag, soldiers in the past who forgot that the flag was merely a symbol with no inherent value died trying to recapture them for the reality it represented. "The flag itself is treated as if it was that reality." 741 Durkheim did not move far beyond his theory of contagious transference to describe how the flag actually gets its power and left underdeveloped his ideas regarding how a group's identification with its emblem occurs. However, it is notable that from time to time blood must be spilled in times of war for the flag to increase members' belief in its power to promote group solidarity. ${ }^{742}$

Durkheim was aware for the need for historical continuity and stressed the significance of periodic commemorations, communal feasts, and public festivals that assured continuity over time and cohesion across the ages. ${ }^{743}$ These acts, what Durkheim called rites and cults, are also staples of collectivity for groups smaller than the whole of society and even he understood it was possible to expand the ideas of religiosity: there were rites without gods and not all religious virtues emanated from divine personalities. Religion was "broader than the idea of gods or spirits and so cannot be defined exclusively in those terms." Religion had certain components, Durkheim argued, that promoted collectivity, such as feasts and sacrifices (positive rites and cults). Specifically, positive rites of initiation entice and introduce new members into religious life by using "ceremonies...to bring about the death [of individualism] and rebirth" of the individual

\footnotetext{
${ }^{741}$ Ibid., 221-22.

${ }^{742}$ Robert Shanafelt, "The Nature of Flag Power: How Flags Entail Dominance, Subordination, and Social Solidarity," Politics and the Life Sciences 27, no. 2 (2008): 14-15.

${ }^{743}$ Halbwachs, 26.
} 
into the collective. That person is "exhorted to retire completely from the profane in order to live an exclusively religious life." $" 744$ This very act is one that the Army uses extensively to transform civilians into soldiers, to socialize them into the Army's unique culture. Oftentimes, these rites center on occurrences from the past where an event took place, such as a battlefield. The link between these landscapes of memory, the places where rites intend to evoke memory, and history is not new. The semiotics of place remained largely unnoticed until Maurice Halbwachs, who, as a student of Emile Durkheim, examined its role in the formation of collective memory. While Halbwachs understood the timeless, stable quality of geographical sites and asserted that space endures time and has a power that can pull individuals together, Durkheim's ideas on social solidarity requires further explanation. Collective thought, according to Halbwachs, had the best chance of lasting when it concentrates on a place that molds its character with individuals in a collective, whose individuals can be reified in these settings. Halbwachs was especially drawn to Durkheim's thoughts on spiritual, celebratory, and commemorative landmarks that inspired visitors with idealism and pride. $^{745}$

As mentioned previously, Durkheim delineated cults, the combination of rites, into two categories in his theory: negative cults and positive cults. Negative cults were prohibitive prescriptions while positive cults are those that required certain actions. Furthermore, both were separations of the sacred (religious) from the profane (secular) and like totemic symbolism, positive and negative cults were representations of social and moral interests. For a negative cult, the member of the group subdued his personal

\footnotetext{
${ }^{744}$ Durkheim and Fields, 37.

${ }^{745}$ Gillis, 258-59.
} 
inclinations and symbolically aligned his interests with that of the group. ${ }^{746}$ The Army has a specific term for a type of this negative cult: the Army Value of selfless service. While selflessness is not something many attribute to contemporary American culture, it is in fact more probable than not. For example, Americans are the "least likely to defend the individual against national interests" as compared to citizens of other large Western industrialized nations, and Americans tend to display an intense loyalty to the nation, at least during times of national crises such as the 9/11 attacks. As one study suggested, at certain times voluntarism is a distinguishing characteristic of American culture, not individualism. $^{747}$

The importance of positive cults is that they set collectivity in motion with groups coming together to celebrate and acknowledge publicly the solidarity and consciousness of the group. Society, or subgroups within the Army, cannot revitalize their sense of community without assembling but cannot remain functional and be perpetually assembled, hence the need for regular and established times set aside for celebrations. ${ }^{748}$ Military balls, dining-in and dining-out events, promotion and award ceremonies, change-of-command and retirement ceremonies, and celebrations centered on historical events represent types of positive cults in which Army subgroups participate. These types of cults align themselves with Durkheim's description of representative or commemorative rites, those that "keep faith with the past and preserve the group's moral (collective conscious) identity, not because of the physical effects it can bring about." These celebrations, a kind of "ritual mentality," continue because a group's forbearers

\footnotetext{
${ }^{746}$ Durkheim and Fields, 320-21.

${ }^{747}$ Claude S. Fischer, "Paradoxes of American Individualism," Sociological Forum 23, no. 2 (2008): 36668.

${ }^{748}$ Durkheim and Fields, 352-53.
} 
also celebrated them and current members are attached to the past through tradition. What matters most in the positive cult is that individuals assemble periodically and that feelings in common are expressed through actions in common, affirming the group's collectivity and solidarity. ${ }^{749}$

Durkheim detailed the basic and essential elements of religious life through a distinction between the sacred and profane, ideals of soul, spirit, mythical personality, national and international divinity, negative cults, and positive cults of mimetic, commemorative, and piacular rites. Moreover, he stated that "there is something eternal in religion" and that there can be no society "that does not experience the need at regular intervals to maintain and strengthen the collective feelings and ideas that provide its coherence and its distinct individuality...through meetings, assemblies, and congregations...."750 Durkheim focused on the religions of smaller groups (clans) to explain the overall social effects of religion upon society. Nevertheless, these same principles apply to subcultures like the Army. Taken together with mechanical and organic solidarity that is systemic in the Army, the collective nature of religious symbols, rites, and cults add to the cohesiveness of this particular group of people. Durkheim's theories certainly provide a valuable framework for understanding how the Army and other military organizations achieve a unique state of social solidarity rarely realized in civil society.

The Army is a unique subculture: it has its own songs, symbols, clothing, and behavioral norms. Members speak a jargon not understood in mainstream society. The institution has its own set of codified laws, rules, hierarchies, and regulations as well as a

\footnotetext{
${ }^{749}$ Ibid., 375, 82, 90-91.

${ }^{750}$ Ibid., 418, 29.
} 
set of values, codes of conduct, creeds, and belief systems. It also has its own history and heritage, rites and rituals. Socialization into the subculture, the adoption of institutional normative behaviors, and adherence to rules and regulations are highly valued processes used by the Army and its members. The suspension of civilian sensibilities or desired social outcomes becomes necessary when understanding military culture. The Army, in particular, touts itself as an inclusive organization yet is very exclusive with who may become members. One can be too overweight, too short, have too much of a criminal past, or be a user of federally illegal substances - just a few examples or characteristics that make individuals ineligible for membership. The Army does value cognitive diversity and welcomes individuals from all backgrounds to join, assuming they meet certain requirements, but once one volunteers, they cease to be a volunteer. Legally and voluntarily removing oneself from membership is difficult, often impossible. And the Army values different perspectives and beliefs, so long as they do not conflict with the normative behaviors and belief systems of the Army. One may be discharged from the collective during a transformational process for "Failure to adapt to the military environment" or for not adapting "socially or emotionally to military life."751 Accepting the organization's belief systems over personal ones may be viewed as a necessity given the need for social solidarity and unity of purpose in endeavors that come with the risk of catastrophe, including death.

Patton the man became Patton the legend and is encapsulated variously in many aspects of Army social life. And for the Army, he became one of its most colorful and recognizable heroes, a hero who became an icon and part of the collective's heritage and

\footnotetext{
751 Army Regulation 635-200 Active Duty Enlisted Administrative Separations (Washington, D.C.:
} Department of the Army, 2016), 87. 
subcultural identity. In-group members found pride in being associated with Patton, found inspiration in his story, and he served as a galvanizing force for many. He became a symbol of the ideal warrior-scholar-leader who many came to identify with. And many members still do. It is to the idea of the hero-icon that I now turn. 


\section{CHAPTER IX}

\section{IN WANT OF A HERO}

We call our children and our lands by their names. Their names are wrought into the verbs of language.... The search after the great man is the dream of youth and the most serious occupation of manhood. We travel into foreign parts to find his works, [and] if possible, to get a glimpse of him. Ralph Waldo Emerson in "Uses of Great Men"752

Soldiers, all men in fact, are natural hero worshipers. General Patton in a letter to his son George, June 6, 1944

What is a hero and why do humans seem so fascinated by them? MerriamWebster defines a hero as a mythological or legendary figure, often of divine descent, endowed with great strength or ability; an illustrious warrior; a person admired for achievements and noble qualities; or one who shows great courage. ${ }^{753}$ On the individual level, who qualifies as a hero, what makes a hero, and who people consider heroes are subjective decisions. There is evidence to suggest that heroes often serve as role models or exemplars for abstract ideas, such as leadership, and for visible qualities such as skill, as will be demonstrated in the final chapter of this study. Pointing to basic human needs may answer why individuals fixate on heroes as people who inspire. Abraham Maslow pointed out that humans have needs beyond the physiological - psychological needs that include belongingness and esteem, as well as the self-fulfillment need of achieving one's full potential. Heroes, as will be discussed, help fulfill these needs. If humans do not

\footnotetext{
752 Ralph Waldo Emerson, Essays and Poems by Ralph Waldo Emerson (New York: Barnes \& Noble Classics, 2004), 280.

753 Merriam-Webster Online, s.v. "hero,” accessed July 19, 2019, http://www.merriamwebster.com/dictionary/hero.
} 
need heroes explicitly, there is at least a strong desire to have them and they do have utility at both the individual and collective levels of analysis.

Since the dawn of human consciousness, heroes took several forms in the human psyche and ever since philosophers and thinkers demonstrated the utility and consequence of heroes and their stories. The great Scottish philosopher Thomas Carlyle wrote that the importance of heroes was paramount, existential even, for humanity. According to Carlyle, the history of "Great Men," is the very foundation of the history of human accomplishment. These individuals were leaders who demonstrated greatness and were

modelers [sic], patterns, and in a wide sense creators, of whatsoever the general mass of men contrived to do or to attain; all things that we see standing accomplished in the world are properly the outer material result, the practical realization and embodiment, of thoughts that dwell in the Great Men sent into the world: the soul of the whole world's history, it may just be considered, were the history of these.

Carlyle believed these types of people were impossible to ignore and have personal utility for the admirer. One cannot look upon heroes, he argued, "without gaining something by them."754 Particularly, heroes serve as the realized ideal of every person who looks to them, the embodiment of that which they strive to become themselves. The heroes that people choose, then, illustrate what they cherish most about the human spirit. They are the mirrors into which people gaze and judge themselves. "We all love great men; love, venerate and bow down submissive before great men; nay can we honestly bow down to anything else?" 755

For thinkers like the American transcendentalist philosopher Ralph Waldo Emerson, heroes were not simply those who were heroic. Often they were those who

${ }^{754}$ Carlyle, 5 .

${ }^{755}$ Ibid., 13. 
demonstrated a higher sphere of thought, or evoked others to consider abstractions, but were still relatable on a personal level to their admirers. What good was a hero if (s)he was not ${ }^{756}$ A distinction between heroism and heroes needs to be drawn. Fittingly, this was one of Patton's favorite subjects on which he thought and wrote extensively. For example, Patton recognized that

The hero is of truth a rarity. The most striking proof of this is found in the fact that throughout myth, legend, song, and story he has invariably shared with that other rarity, beauty, the place preeminent. Much heroism exists, but few heroes [emphasis added]. It is rather disheartening to observe that man in his efforts to reduce danger has enhanced the requisites for courage necessary to withstand it. The death, noise, excitement, and bodily contact of the close encounter act as a sedative on the brain, the seat of fear. After the rush has started it takes less hardihood to charge than to sit stolidly in a ditch awaiting dissolution via the impersonal belch of a dropping shell.... The romantic literature of the war [WWI], now as always, centers on the exploits of heroes. Unthinking people imagine that in the future all machines will be operated by these rare individuals and that the phenomenal results attained by the few will be duplicated by the many. In sport we have Sande, Tilden, and Jones, whose exceptional capabilities we admit and admire. Yet, in war we fondly imagine whole armies of Sergeant Yorks and Guynemers. Popular antipathy to unhappy endings induced writers to have their heroes 'live happily ever after,' whereas, in fact, only too many citations for valor end, 'For this act he was awarded the Medal of Honor, posthumously. 757

Although the term hero is liberally cast about today, the heroic are rare indeed and

most go unnoticed. It must be forgiven, then, that those exceptional few who do become widely known as heroes are so captivating to so many. Yet while many heroes become thusly through acts of heroism, it is not always the case. Ironically, Patton, who desired to be killed by the last bullet in the last battle of the war, gained his hero status not through heroic deeds. Although Patton certainly demonstrated heroic actions during combat, particularly during the First World War, it was his actions as a leader and commander during World War II that elevated him to hero status.

Sociologist Max Weber explained this phenomenon with his discussion about charismatic figures, which he defined as self-appointed leaders who were followed by

\footnotetext{
${ }^{756}$ Emerson, Representative Men, 281-82.

${ }^{757}$ George S. Patton, "The Effects of Weapons on War," Cavalry Journal (November 1930): 41.
} 
people in distress because they believed the leader was uniquely and extraordinarily qualified. Weber placed great emphasis on the rise of charismatic leaders whom he viewed as revolutionary forces in history, those who were opposed to institutional routines, especially bureaucracy. Weber's conception of the charismatic leader is a continuation of the theories purported in Thomas Carlyle's Heroes and Hero Worship, which influenced a great deal of nineteenth-century historical writing, and emphasized the monumentalization [sic] of the individual. Likewise, noted Irish historian and political theorist W.E.H. Lecky broadened Carlyle's conceptualization of heroes by applying it to leaders of human conduct rather than looking at leaders who became symbols. For Lecky, the charismatic leader was a man of ideas as well as the ideal man, whose magnetism had a powerful pull on contemporaries. And yet, as these thinkers understood, enthusiasm builds and kindles, adherence follows, and then gives way into the "routinization" of incipient institutions or organizations. Weber's construction in particular was an attempt to answer a paradox of unintended consequences, that is, whereas charisma incites the followers of a warrior hero, the routinization of charisma turns into traditionalism or bureaucracy. This was not the intention of the charismatic leader. ${ }^{758}$

Max Weber focused on how great figures of history affected their institutions and illustrated how charismatic leaders tended to arise in times of crises. This idea is particularly germane for the Army, especially for leaders of the Patton ilk, which today are rare at the highest levels and only tend to come to the forefront of public discourse during periods of war. The bureaucratic state of the post-World War II Army pushed

\footnotetext{
${ }^{758}$ Max Weber, Hans Heinrich Gerth, and C. Wright Mills, From Max Weber: Essays in Sociology (New York: Oxford University Press, 1946), 51-55.
} 
these types away when they were no longer needed, a deliberate and calculated move by generals with a more corporate bent who directed the institution thereafter. ${ }^{759}$ As Weber posited, the "further we look back in history, the more we find" that natural leaders in times of distress "have been believed to be supernatural, not accessible to everybody." As this study already demonstrated, many people viewed Patton as something of a demigod or legend, but that attitude shifted as the needs of news and public memory consumers changed. Regardless, those who led by virtue of the gift of charisma, like Patton, carried a certain appeal for admirers. In contrast to bureaucracies and their tendency to morph into a state of stasis, the charismatic structure knows nothing of normalization. "Charisma knows only inner determination and inner restraint. The holder of charisma seizes the task that is adequate for him and demands obedience and a following by virtue of his mission." Simply put, rarely is the name of a bureaucrat remembered by members of a large institution: the charismatic leader on the other hand can become a legend. ${ }^{760}$

Pure charisma, as Weber put it, is the opposite of ordered systems - it is not institutional or permanent, standing outside of routine. It does not know any other legitimacy other than that which comes from personal strength and force of personality. "The charismatic hero does not deduce his authority from codes and statutes" as does the bureaucratic managers of systems. ${ }^{761}$ This is an interesting dichotomy for the military. There is ever present in leadership ranks a growing and continuous frustration with the

\footnotetext{
${ }^{759}$ For an examination of the corporate, bureaucratic nature of today's Army, see Thomas Ricks, The Generals: American Military Command from World War II to Today (New York: Penguin Press, 2012). ${ }^{760}$ Weber, Gerth, and Mills, 245-46.

${ }^{761}$ Ibid., 248.
} 
military bureaucracy, which is an underlying factor in Patton's popularity. ${ }^{762} \mathrm{He}$ represents what many military leaders wish the service could be, a symbol in their sense of nostalgia for a time long past when charismatic leaders led vast armies rather than the bureaucratic quagmire in which many view the service in its current form. Yet Weber was a determinist and argued that bureaucracy was an inevitable outcome of large social structures like the military. While this may be true, however, charismatic leaders or heroes arise from time to time during periods of crises but then are cast aside afterwards. Much was the case for Patton.

Patton, the charismatic hero, placed a premium on military discipline, a feature that Weber had a sociological explanation for as well. Discipline is not hostile to charisma. In fact, charismatic military leaders can use strict codes of discipline to maintain their status over subordinates. Habituation and training helps to secure blind obedience and submission to the disciplinary code. Likewise a charismatic hero may make use of discipline to expand his or her sphere of domination. Discipline can be rationally calculated as well. Weber explained the utility of discipline for the charismatic leader in the martial arts:

Enthusiasm and unreserved devotion may, of course, have a place in discipline; every modern conduct of war weighs, frequently above everything else, precisely on the 'moral' elements of a troop's endurance. Military leadership uses emotional means of all sorts - just as the most sophisticated techniques of religious discipline.... In combat, military leadership seeks to influence followers though 'inspiration...."763

Furthermore, the sociologically decisive points in discipline as they relate to unit effectiveness are two-fold: first, that "irrational emotional factors," which the military

\footnotetext{
${ }^{762}$ For an example of frustration with the military bureaucracy, see Neal Conon, "Top Military Officers Abandon Armed Forces," https://www.npr.org/2011/01/13/132904846/top-military-officers-abandonarmed-forces.

${ }^{763}$ Weber, Gerth, and Mills, 254.
} 
calls esprit de corps and morale, can be rationally calculated and instilled through inspiration; and second, devotion to a common cause is an objective character. This does not simply imply devotion to a person, no matter how much a fascinating, charismatic leader can inspire. The final part of Weber's conceptualization of the equation used by the charismatic leader, aside from devotion and inspiration, is integration. Integration "is a strong element in the efficacy of all discipline...." It is an element that remains in spite of the absence of the charismatic leader. ${ }^{764}$ Patton understood this concept as well as anyone and made it a part of the equation he used to build effective units. But as charisma remains a highly important element of the social structure it inevitably "recedes in the face of domination [of the bureaucracy], which hardens into lasting institutions, and becomes efficacious only in short-lived mass emotions of incalculable effects...."765 The Hero Archetype

There are residual effects of dead charismatic leaders of an institution's past and their memory and stories can and do still inspire members. The bureaucratic nature of those organizations almost certainly does not. So, then, if institutions use heritage to create a sense of belonging with its members in a transformational process, heroes are useful resources. And the reasons for which may be rooted in something far more entrenched than the sociological explanations offered by Weber, Carlyle, Lecky, Emerson, or other thinkers of that vein.

The depth of the importance of heroes may be encoded in our DNA. The theories of analytical psychologist Carl Jung are also germane to understanding how and why the Patton legend evolved, how he became an institutional icon, and why the memory of him

\footnotetext{
${ }^{764}$ Weber, Gerth, and Mills, 253-55.

765 Ibid., 262.
} 
persists inside the Army. On the individual level of analysis, Jung dealt with the concept of a collective unconscious, an idea that pertains to approaches to archetypical heroes. Fantasies of an impersonal character, as those seen in dreams or other states of reduced intensity of consciousness, that transcend space, time, populations, and cultures, and which cannot be explained as something individually acquired, as in the personal subconscious, have their closest analogues in mythological types and correspond to collective structural elements of the human psyche. The connections people have to archetypical hero stories, as Jung posited, constitute part of the collective unconscious. ${ }^{766}$ They are the deeply embedded and inherited stories that explain our existence and condition.

The art of storytelling is an important facet in the evolutionary biology of human beings. It is the way our ancestors transferred information, knowledge, and wisdom from person to person and generation to generation for hundreds of thousands, if not millions, of years. Anatomically modern Homo sapiens arrived on the scene roughly 150,000 to 250,000 years ago and yet human beings have only been transferring information via the written word for around 5,000 years in comparison, and when accounting for literacy rates that timeline becomes very condensed, far too short for any considerable evolutionary changes in the way humans learn. ${ }^{767}$ Archetypal content, the foundation upon which abstract ideas were understood, expresses itself in metaphors. As Jung posited, these metaphorical symbols are incredibly powerful: "we can never legitimately

\footnotetext{
${ }^{766}$ C. G. Jung, The Archetypes and the Collective Unconscious, trans. R. F. C. Hull (Princeton University Press, 1990), 155.

${ }^{767}$ Martin Porr, "Lives and Lines: Integrating Molecular Genetics, the 'Origins of Modern Humans' and Indigenous Knowledge," in Long History, Deep Time: Deepening Histories of Place, ed. Ann McGrath and Mary Anne Jebb (Canberra, Australia: Australian National University Press, 2015), 203-20.
} 
cut loose from our archetypal foundations unless we are prepared to pay the price of a neurosis, any more than we can rid ourselves of our body and its organs without committing suicide." At every new stage in the advancement of human consciousness, the task becomes finding a new and appropriate interpretation "in order to connect the life of the past that still exists in us with the life of the present," and if this does not occur, "a kind of rootless consciousness comes into being no longer oriented to the past...."768 Perhaps if there is no overwhelming evidence of the use of the Patton collective memory in younger generations of members of the Army there simply needs to be an updated interpretation of his story.

According to Jung, archetypes appear to be involuntary manifestations of unconscious processes whose existence and meaning can only be inferred. Meanwhile, the myths embodying those archetypes deal with traditions of incalculable age, harking to a prehistoric world when spiritual preconceptions existed amongst "primitives." These myths can be understood as original revelations of the preconscious human psyche, involuntary statements about unconscious happenings, and anything but allegories of physical processes. They are buried deep in the subconscious and have helped humans understand their world since well before the invention of the written word. These myths and the archetypical characters embedded in them are vital sources of meaning. ${ }^{769}$

Try as we may, at no time have humans been capable of entirely eradicating a peculiar reverence, admiration, loyalty to, and adoration for outstanding individuals of the past. The involuntary action is buried deep in our consciousness, put there through evolutionary processes. Hero worship is as old as the archetypal hero, which, as Jung

\footnotetext{
768 Jung, 155, 57.

769 Ibid., 153-54.
} 
argued, is as old as human consciousness. ${ }^{770}$ Emerson also understood that the phenomenon was naturally occurring: "It is natural to believe in great men. If the companions of our childhood should turn out to be heroes, and their condition regal, it would not surprise us. All mythology opens with demigods, and the circumstance is high and poetic; that is, their genius is paramount." Our heroes manifested themselves in many aspects of our culture, as was the case with Patton. As Emerson went on to describe, "We call our children and our lands by their names. Their names are wrought into the verbs of language, their works and effigies are in our houses, and every circumstance of the day recalls an anecdote of them." ${ }^{\text {771 }}$ This, of course, may be an overreach - it is unlikely that heroes are in the forefront of modern human consciousness in every daily circumstance, but that does not belie the overall point. Heroes play a major role in the making of meaning: personally, societally, and particularly, culturally.

Archetypal content takes form in the shape of symbols that are easily recognizable even if individuals have no explanation for why. The power of narrative is undeniable and critical to human understanding. Yet, cultural change within society is inevitable. This is not to suggest that the archetypes will ultimately become of little use, but rather that societies habitually retool those narratives to fulfill current understanding of the world. There is always a tendency in the human unconscious psyche to produce a symbol of the self alongside the archetypal symbols and place them within a larger context. Although Jung described the importance of archetypal symbols to the subconscious and their staying power, he also understood that these narratives had no simple formula in

\footnotetext{
${ }^{770}$ Carlyle, 13.

${ }^{771}$ Emerson, Representative Men, 280.
} 
their formation. These symbols of reality persisted though the ages but required reinterpretation so that modern people may continue to use them.

Archetypal heroes lend more to us than just stories to help us make sense of our world. They become symbols for abstractions, a stand in for an idea or an ideal. As already demonstrated, there is a preponderance of physical evidence of Patton's hero status, typically in the form of memorials. Historical memorialization greatly depends upon the interpretation of a signifier, a word or symbol that stands between the viewer and the event or person commemorated. When a powerful icon or symbol enters into the circulation of collective memory from the collective subconscious, its connotations are set in motion. ${ }^{772}$

The utility of icons, symbols, and the archetypes are widely varied according to traditions, customs, or cultures, but some may warrant note here. First, as a matter of introspection, heroes may serve as a mechanism against which we measure and orient ourselves. They have the potential to be "lenses through which we read our own minds. Each man seeks those of different quality from his own, and such are good of their kind; that is, he seeks other men, and the otherest [sic]." From one sociological perspective, people tend to surround themselves with persons who have qualities they lack. ${ }^{773}$ From another perspective, that of homophily, people are "inclined to mixing with each other who are similar to them than with randomly selected members of the same population." Personal networks "tend to be more homogenous than heterogeneous such that the communication between similar people occurs more frequently than with dissimilar

${ }^{772}$ Gillis, 260.

${ }^{773}$ Durkheim and Lukes, 46. 
people.”774 The same can be said for our heroes. Heroes tell us who we are not and who we hope to become like. They are a means for a society (especially collectives) to tell its members what are important qualities for a person to possess, a means to pass a system of values and morals to subsequent generations. They often remind us what is good in humanity.

Secondly, heroes represent ideals, those things that a population holds in high regard. To understand a culture, look to those who that population admires. In particular, there is a nearly universal human fascination with war and the types of warrior heroes it creates. ${ }^{775}$ For the warrior hero archetype, often revered for the power of their acts and the mysterious nature of the world within which they function, for the average citizen the warrior often becomes a symbol or icon that embodies ideals such as bravery, honor, or social responsibility. ${ }^{776}$

Another way of appreciating the value of heroes is to understand them as a means of checking personal ego: "Great men are thus a collyrium [eye wash] to clear our eyes from egotism and enable us to see other people and their works."777 Or perhaps the philosophers named previously were correct in saying that archetypes, heroes, icons, or symbols are a means of understanding the past and an individual's place in the present. For better or for worse, interpretations and narrative more so than facts shape "our understanding of the past, our orientation in the present, and our models for addressing the future. For most people, the facts of war are less evocative than the stories we tell,

\footnotetext{
${ }^{774}$ Kazi Zainab Khanam, Gautam Srivastava, and Vijay Mago, "The Homophily Principle in Social Network Analysis," Proc. ACM Meas. Anal. Comput. Syst. 37, no. 4 (May 2020), Article 111, 1.

${ }^{775}$ Linenthal, vii.

${ }^{776}$ Ibid., Xv.

${ }^{777}$ Emerson, Representative Men, 281-82, 91.
} 
the heroes we venerate, the martial liturgies we celebrate." 778 Those real warriors, such as Patton for instance, who become legends, icons, or heroes and embody the archetypal hero narrative are models of bravery and courage. They are the embodiment of what later generations of warriors hoped to become, that which they measured themselves against. This martial mythology is a complex of narratives and rituals that shape our collective memory of war and the warriors who fought them. Novels, films, plays, songs, martial icons, and all the elements of popular culture provide the vibrant symbols through which people interpret what war is and what war means. ${ }^{779}$

Philosophers and poets have been contemplating the importance of heroes for society for ages. Plato, for example, had plenty of thoughts on the importance of hero worship. ${ }^{780}$ In more modern times, Carlyle, Emerson, and Jung also recognized this phenomenon. All of the ancient wisdom passed on through the centuries through the stories our ancestors told, coupled with the ideas of more recent thinkers, should not be so cavalierly thrown aside to make way for new philosophies or worldviews, especially those that are problematic or controversial. It was Carlyle who insisted that the worship of a hero, or more realistically the admiration of great men [or women] was as important in his time as it ever was and was at the root of society and civilization itself. Durkheim would probably agree, as he understood religion as a social phenomenon. Assuming his logic and theory was sound, the worship of a hero or of a religious deity, the trademark of religion, is the base of human social activity. There has been no time in history in which a great person did not live, one whom the times needed. As Carlyle asserted, "In all

\footnotetext{
${ }^{778}$ Linenthal, viii.

779 Ibid.

${ }^{780}$ A. Hobbs, Plato and the Hero: Courage, Manliness and the Impersonal Good (Cambridge: Cambridge University Press, 2000).
} 
epochs of the world's history, we shall find the Great Man to have been the indispensable savior of his epoch." ${ }^{781}$ Indeed Patton may have been one of those persons, and there is evidence to support that notion. His efforts during World War II alone contributed immensely to the positive outcome of that great conflict. If the "history of the world...was the biography of Great Men," then there is little doubt why Patton's name maintains its staying power. ${ }^{782}$

During the 1990s a group of professional historians set out to understand how people on an individual level understand and use the past. Using the survey results from a nationwide probability sample conducted in the United States, these historians, with the help of some social scientists, discovered among other illuminating aspects of Americans' relationship with the past and history, that some respondents "found strength to change the course of their lives by looking to people who had successfully solved the same problems," particularly famous figures. ${ }^{783}$ For those respondents who selected national figures as models of behavior, they often treated them like family, viewing national figures as personally inspirational role models for "proper and moral behavior." Other respondents constructed and used narratives in which a national leader offered messages about making a difference in the world. People tend to use the lives of figures from the past as lessons about "good living and proper behavior." The argument that Americans still have a use for heroes is convincing. ${ }^{784}$ And this is not a recent phenomenon. As Emerson noted in another epoch, people "have in all ages attached themselves to a few persons who either by the quality of that idea they embodied or by

\footnotetext{
${ }^{781}$ Carlyle, 11-13.

${ }^{782}$ Ibid.

${ }^{783}$ Rosenzweig, 76.

${ }^{784}$ Ibid., 127-28.
} 
the largeness of their reception were entitled to the position of leaders and law-givers. They teach us the qualities of primary nature, and admit to us the constitution of things. ${ }^{7} 785$

The following chapter of this study illustrates that the ideas of thinkers like Weber, Jung, Emerson, and Carlyle were not off base. Another more recent tool, Affective Disposition Theory (ADT), first posited by Dolf Zillmann and Joanne Cantor in 1972, may also prove useful as a mechanism to analyze the extent to which hero narratives resonate with people and the importance heroes play sociologically as well as psychologically. ${ }^{786}$ Current research indicates that college-age audiences are among the most avid global consumers of sports and sports news, which may provide insights into the level of influence hero narratives have on this particular population. ADT asserts that media and entertainment users make moral judgments about characters in a narrative, which affects their enjoyment of that narrative. One way in which myth is offered to consumers is through the archetypical hero narrative Jung attended to, the story in which a hero goes through a sequence of humble beginnings, fantastic achievements, obstacles faced and overcome, a short-term failure, and a return to prominence. Audiences then invoke the hero narrative schema and develop expectations about how the narrative should unfold. That schema becomes a template representing a cognitive framework that helps consumers organize and interpret information. ${ }^{787}$ In conjunction with Jung's thoughts on the importance of archetypes for humans in the development of a worldview,

\footnotetext{
${ }^{785}$ Emerson, Essays and Poems by Ralph Waldo Emerson, 288.

${ }^{786}$ Dolf Zillman and Joanne Cantor, "Directionality of Transitory Dominance as a Communication Variable Affecting Humor Appreciation," Journal of Personality and Social Psychology 24, no. 2 (1972).

${ }^{787}$ Leah M Omilion-Hodges Sue Ellen Christian, "Emotional Reactions to Sports Heroes' Rise and Fall: Application of Affective Disposition Theory Via the Hero Narrative," Journal of Mass Communication \& Journalism 4, no. 6 (2014).
} 
ADT is useful for understanding the reasons why young people identify with and have emotional reactions to their heroes. The archetypical hero story is older than the written word and is a story told over and over again to great effect. Every generation rehashes the same tale. It is Homer's Iliad and the knight in shining armor that rescues the princess from the dragon. It is Jackie Robinson, Luke Skywalker, Jesus of Nazareth, and Bilbo Baggins. It is d'Artagnan, Joan of Arc, Hercules, Pinocchio, and Katniss Everdeen. The hero's journey offers an avenue for institutions such as the U.S. Army to keep iconic figures like Patton relevant to younger service members.

Sense-Making theory (SMT), introduced into organizational studies by Karl Weick in the 1970s, also provides a lens through which to look at the creation and use of heroes as symbols. ${ }^{788}$ The process of sense making generally refers to the means which people use to understand ambiguous, equivocal, or confusing events. One stream of SMT deals with narratives and stories, or creating metaphorical tools for meaning making. This particular thread of SMT addresses identity, a processes through which members of an organization construct and maintain individual, cultural, social, group, professional, or organizational identities, typically through the use of narrative or story. The stories that members of an organization tell each other and pass from one generation to another provides a sense of belonging and continuity over time: they are a crucial element of institutional memory, the understanding of how an organization operates and why. Individuals within an organization that uses a transformational process to socialize new

\footnotetext{
${ }^{788}$ Karl E. Weick, Sensemaking in Organizations (Thousand Oaks, CA: Sage Publications, Inc., 1995).
} 
members, such as the Army, rely heavily upon narrative and story to create an identity or sense of belonging within members of the institution. ${ }^{789}$

The transformational processes that organizations use on new members has also been studied. For instance, Victor Turner's ideas of liminality and communitas indicate that there is a lack of status of those individuals within the transformational process who have not yet gained entry into the organization but must pass through a series of rituals in order to become full members. As Turner explained, rites of passage such as the Army's transformational process, are periods of transition marked by three phases: separation, margin, and aggregation. Separation includes the exhibition of behaviors that signify detachment of individuals from previous states or status within the outside social structure. In the case of military initial training, as an example, trainees are purposefully stripped of individual identities in order to create a "blank page," so to speak, upon which a new primary identity, that of "soldier," may be imprinted. The intervening period, that of liminality or the margin, is marked by ambiguity as individuals pass through a cultural realm in which they have few or no attributes of their past status or those of the social organization of which they strive to gain membership. They are "neither here nor there; they are betwixt and between the positions assigned and arrayed by law, custom, convention, and ceremonial." ${ }^{\prime 790}$ Individuals within this stage of liminality are normally "passive and humble," as though "they are being reduced or ground down to a uniform condition to be fashioned anew....,791

\footnotetext{
${ }^{789}$ Ian Colville Andrew Brown, Annie Pye, "Making Sense of Sensemaking in Organizational Studies," Organizational Studies 36, no. 2 (2015).

${ }^{790}$ Victor W. Turner, The Ritual Process: Structure and Anti-structure, (New York: Aldine De Gruyter, 1969), 95.

${ }^{791}$ Ibid.
} 
During the liminality period, individuals undergoing the same process "tend to develop an intense comradeship and egalitarianism" in which "distinctions of rank and status disappear or are homogenized" within an unstructured community they develop amongst themselves. ${ }^{792}$ This phenomenon, which Turner described as communitas, is also characterized by the submission of individuals to the authority of full members. And it is understood by individuals within a state of liminality that full members of the organization have themselves undergone the same type of process: "he who is high must experience what it was like to be low." ${ }^{, 793}$ That passage is finally consummated during the final phase of aggregation, the status in which those individuals achieve a stable state as full members with obligations to maintain behaviors in accordance with customary norms. ${ }^{794}$ The normative behaviors inscribed upon and adopted by full members during their liminal experience are not cast aside after aggregation, although feelings of communitas may be short lived experiences that serve to bind individuals together during liminal experiences.

The relevance of this theory to ROTC cadets, the subject of study in the following chapter, who have only a loose connection to the Army and are undergoing the transformational process, is easy to see. ${ }^{795}$ The rituals and rites of passage Turner outlined are very much in line with Durkheim's arguments on mechanical and organic social solidarity and religious symbols, rites, and cults. Likewise, communitas, the dual concepts of homogeneity and comradeship, are important for understanding how aspiring

\footnotetext{
792 Ibid., 95-96.

793 Ibid., 97.

${ }^{794}$ Ibid., 95.

${ }^{795}$ For an example of how liminality relates to college-age individuals, see Alison Cook-Sather, "Newly Betwixt and Between: Revising Liminality in the Context of a Teacher Preparation Program," Anthropology and Education Quarterly 37 (2006).
} 
members practice and come to know the process of gaining social solidarity and further illustrates the Army as a unique subculture, into which membership is granted through a transformational process that includes a period of liminality. ${ }^{796}$

\section{A Challenge to Heroes}

While there are plenty of theories and studies on several different levels of analyses that indicate heroes still maintain an important place in the consciousness of many Americans and that those heroes play an important role in culture, it appears to some writers and thinkers that there are intellectual and populist forces that actively attempt to minimize, invalidate, or revise the meanings associated with these figures that many in the general population draw upon. Within every society there is some representation of hero worship, reverence given to great and wise individuals. Yet even Carlyle lamented in his time hero worship "professes to have gone out, and finally ceased. This...is an age that as it were denies the existence of great men; denies the desirableness of great men." 797

Of course, Carlyle died in 1881 but this statement could easily be said today and remain relevant. During the public outcry for justice in response to episodes of alleged police brutality in mid-2020, protestors initially began demanding the removal of statues of Confederate generals and leaders, slave traders, and slave owners. This is not to suggest that these were monuments to "great men," rather to illustrate that public memory, as it has always been, is concerned with the present. And as an ongoing phenomenon it is not clear where the line will be drawn. Every new generation critiques

\footnotetext{
${ }^{796}$ Victor W. Turner, The Ritual Process: Structure and Anti-structure, The Lewis Henry Morgan lectures, (Chicago,: Aldine Pub. Co., 1969).

${ }^{797}$ Carlyle, 12.
} 
those before it, but it appears to some factions in our society that critics of national heroes are doing more today to erase heroes of the past rather than expand space for more. This is a period in which English major students at Yale University make calls for erasing requirements to study the writings of Chaucer, Spenser, Milton, and Wordworth. ${ }^{798}$ Statues of individuals that presumably not many people would suspect were in danger were torn down, such as one of the abolitionist Frederick Douglas in Rochester, New York. ${ }^{799}$ Nor are our national military heroes immune from public critique any longer. Take, for instance, the actions of those who wish to erase from public memory likenesses of George Washington by claiming that the presence of memorials dedicated to him makes them feel "unsafe." ${ }^{" 800}$ Calls for the erasure of long-accepted heroes inevitably draws the ire of those who remain attached to them, particularly, as will be discussed in the following chapter, those whose sense of personal and social identity are tied to those narratives.

In response to the destruction and removal from public spaces monuments and statues by protestors in 2020, the President of the United States issued an executive order for the purpose of transmitting "our great national story to future generations through newly commissioned monuments to American heroes" through the creation of a National Garden of American Heroes. In the proposed garden would be statues of "historically

\footnotetext{
798 Victor Wang, "Student Petition Urges English Department to Diversify Curriculum," Yale News (May 26, 2016), https://yaledailynews.com/blog/2016/05/26/student-petition-urges-english-department-todiversify-curriculum/.

${ }^{799}$ DeNeen L. Brown, "Frederick Douglass Statue Torn Down in Rochester, N.Y., on Anniversary of his Famous Fourth of July Speech," accessed July 6, 2020, https://www.washingtonpost.com/history/2020/07/06/frederick-douglass-statue-rochester-attacked. ${ }^{800}$ Max Greenwood, "George Washington's Virginia Church Taking Down His Memorial," https://thehill.com/blogs/blog-briefing-room/news/357608-george-washingtons-virginia-church-takingdown-his-memorial. For a treatment on the pitfalls of using "safety" rhetoric outside the bounds of actual physical danger, see Greg Lukianoff and Jonathan Haidt, The Coddling of the American Mind: How Good Intentions and Bad Ideas are Setting Up a Generation for Failure (New York City: Penguin Books, 2018).
} 
significant Americans" who "made substantive contributions to America's public life or otherwise had a substantive effect on America's history." Of the thirty original proposed individuals to be included in the garden were four military figures - including George S. Patton, Jr. ${ }^{801}$ While it is too soon to understand the consequences of this executive order, viewing it as a political move, as undoubtedly many Americans did, Patton once again figured into the agenda-driven nature of public memory devices. Unfortunately, it may signal that Patton may also play some role in the ongoing "culture war." 802

From the perspective of some scholars outside academia (and a few within) there are several philosophies taught in colleges and universities that endanger the stories about ubiquitous figures while many vocal students (and some faculty) simultaneously decry the prominence and use of "dead white men" as archaic, not in keeping with modern sentimentality. It stands to reason why every generation or subculture has in internal struggle to remove or maintain cultural icons - collective memory is intrinsically tied to collective identity, and outside attacks on symbols brings the perception of assaults on the collective.

Critical theorists and postmodernist thinkers deride grand narratives (and the linguistic tools used to describe them) and the very notion of the mastery of facts as mere means to reinforce the hegemony of white Western men over other races, peoples, and women. ${ }^{803}$ Naysayers point out that famous white men are also easy targets for postcolonialism and Marxist philosophers, deconstructionists, third and fourth-wave

\footnotetext{
${ }^{801}$ Exec. Order, "Executive Order on Building and Rebuilding Monuments to American Heroes, July 3, 2020," https://www.whitehouse.gov/presidential-actions/executive-order-building-rebuilding-monumentsamerican-heroes/.

${ }^{802}$ For a definition and description of "culture war," see James D. Hunter, Culture Wars: The Struggle to Define America (New York: Basic Books, 1991).

${ }^{803}$ Joyce Appleby, Lynn Hunt, and Margaret C. Jacob, Telling the Truth About History (New York: Norton, 1994), 198-205.
} 
feminists, literary critics, and intersectionality theorists, all of which, according to these opponents, appear to downplay, ignore, decry, or deny the positive contributions made by figures of the past who many people consider heroes. Even within the history discipline, the era of centering historical analysis on key figures is seemingly over, not without good reason, and in its place came the rise of social history with an emphasis on ethnic and racial groups often left out of previous overarching narratives.

Clearly, heroes of the past are at the center of the ongoing "culture war" and have now entered into the realm of political discourse. For those who offer critique, it seems that there are several theories and philosophies actively mobilized to undermine the utility of stories about many national heroes and these ideas are widely taught in American universities, not as theory or matters of perspective, but as fact, particularly in what they dubbed the "grievance studies" departments. ${ }^{804}$ What is not clear is the matter of scale. How far downstream into the general population and our society have these ideas gone, how entrenched are they, and what is the logical conclusion of these ideologies? What are the limiting principles, if there are any? Do heroes like Patton still have a place in any aspect of our culture or within the Army subculture? Will there be room in our society for heroes at all, given that all humans are flawed? If not and the achievements and ideas of the heroes of the past become tossed asunder without considering the sociological and psychological ramifications of such acts may cause many to lament, as Carlyle did: "No sadder proof can be given by a man of his own

\footnotetext{
${ }^{804}$ Heather MacDonald, The Diversity Delusion: How Race and Gender Pandering Corrupt the University and Undermine Our Culture (New York: St. Martin's Press, 2018). For an introduction into the idea of "grievance studies," see "What the Grievance Study Hoax Means," https://www.chronicle.com/article/What-the-Grievance/244753.
} 
littleness than disbelief in great men." 805 However, history offers hope for Patton the hero-icon and those like him. The removal of some statues or stripping controversial figures of hero status may potentially make way for the veneration of new heroes that espouse values that better fit with the changing ideologies, values, and demographics of the nation. These acts could potentially signal a substitution or reinterpretation process in which collectives do with collective memory as they always do - use the past to make sense of the present. Collectives may take the opportunity to reimagine their heroes. Like the collective memory of him, the legacy Patton left for the Army is also traceable, and in that record it appears that the Army subculture remains willing, to some degree, to protect its pantheon of greats and reframe what they meant for the institution. What it chooses to do with the collective memory and legacy of this particular iconic symbol in the context of the ongoing "culture war" remains to be seen and is a matter for honest debate.

${ }^{805}$ Carlyle, 12. 


\section{CHAPTER X \\ HEROES AND TRANSFORMATIONAL PROCESSES}

The great things a man does appear to be great only after they are done. General George S. Patton, Jr.

One of the key stakeholders of the Patton collective memory, the U.S. Army, uses history and heritage in its transformational processes that turn civilians into soldiers and officers. As members undergoing such a process, ROTC cadets go through a rite of passage in order to become full members of the institution who are socialized into its unique subcultural norms and behaviors. Although the central theme of this text is the collective memory of Patton, that memory is scattered and disjointed within the minds of many people, and even within the ranks of the Army. This necessitated taking a broad approach to discover the sources of Patton's legend, how cadets receive the narrative, and its usefulness for meeting organizational ends, such as social cohesion and unity of purpose. Rather than attempt to locate individuals who consider Patton a hero and understand why and how he became so, I sought to discover what certain members thought of heroes and icons in general in order to deduce what that means for a particular subculture. What was unclear in extant literature was the manner in which this specific population, future generations of Army officers, approach narratives of institutional heroes and icons. This is not to say the history of the collective and public memory of General Patton has not had certain sociological impacts on members of this particular collective - his is a brand name, easily recognizable, and known to many. The Patton 
story that turned into a legend (the collective memory) detailed in Part 1 may be used purposefully by taking advantage of how individuals undergoing a transformational process think about and use hero stories, history, and heritage. If they so choose, it is incumbent upon organizations that wish to harness the power of hero stories to understand how constituents actually approach those narratives.

This chapter addresses the following questions in order to unpack how one subset of individuals who are undergoing a transformational process within the Army structure, in this case Army ROTC cadets, use narrative to make sense of themselves and their place in the institution: Who do cadets consider heroes (if they do at all) and what characteristics do cadets find inspirational in those heroes? How do cadets learn about the exploits of their heroes? How can the Army use heroes, including Patton, during its transformational process, considering the answers to the previous questions? Is there an existing collective memory of Patton amongst this generation of service members, and if so, how might that narrative be leveraged to meet the institution's goal of creating socialized members with a sense of unity and shared identity?

Several observations led to these research questions. While working at the Patton Museum, the existence of a collective memory of Patton became clear to me, as did the pervasiveness of Patton's popularity amongst older generations (and their proclivity to identify with him). Empirical research into the beginnings of the Patton legend and public memory led to the same conclusion. Second was the technical literature. Left unanswered was whether or not younger people resonate to grand hero narratives at all. There is an inherent problem with existing memory studies literature, particularly with the measuring of reception. Evidence of projections, such as memorials, 
commemorations, or museums, is easily accounted for, but in studies previous to this one, any internalization of intended messaging was lacking in those examinations. Lastly, in my personal and professional experience, I noticed the Army's history program and the Center of Military History's policies towards the role and use of history do not take into account how constituents approach and use history. ${ }^{806}$ This highlighted a disconnect between Army policy and relevant literature from several different academic disciplines, scholarship that indicates people approach historical narratives with an identity-driven purpose: they tend to use narratives to create, reaffirm, or reinforce identities. ${ }^{807}$

To understand how to best meet constituents' needs necessitated the development of a grounded theory about this phenomenon, that is, how institutional hero narratives affect or can affect people in a transformational process, by expanding and conjoining several sociological theories and ideas. The aim here was the development of a grounded theory as to how hero narratives affect individual and social transformational processes, contribute to the sociological understanding of how individuals within an organization internalize and interpret projections of archetypical hero narratives, develop or change existing policy to reflect current research, guide practices based on new knowledge, and address the projection/reception problem inherent in memory studies.

\section{Review of Topical Literature}

In chapters I, VIII, and IX, I detailed in depth the topical literature on collective and public memory, as well as applicable sociological theoretical frameworks that serve

\footnotetext{
806 Rosenzweig.

${ }^{807}$ Brenda Trofanenko, "The Public Museum and Identity: Or, the Question of Belonging," Counterpoints 272 (2006); Sharon Macdonald and Gordon Fyfe, Theorizing Museums: Representing Identity and Diversity in a Changing World (Cambridge, Mass.: Blackwell, 1996); Tracy Jean Rosenberg, "History Museums and Social Cohesion: Building Identity, Bridging Communities and Addressing Difficult Issues," Peabody Journal of Education 86, no. 2 (2011).
} 
as a substructure for a theory about the use of heroes by institutions that utilize a transformational process to socialize new members into a subculture. What immediately follows is a brief recapitulation of germane literature on heroes for ease of use.

\section{The Hero's Journey}

On the role and importance of hero narratives, and as a means to define Patton as a hero, Carl Jung's work on archetypical hero narratives and Joseph Campbell's monomyth of the "hero's journey" proved to be exceptionally useful. ${ }^{808}$ Jung's idea of a collective unconscious is similar to the concept of collective memory and pertains to human approaches to archetypical stories, namely those of heroes. Certain fantasies of the human imagination and the drive to act out the hero's journey cannot be explained as something personally acquired, yet still exist and are common cross-culturally. They are seen in the earliest mythological types and correspond to collective structural elements of the human psyche. The connections people have to archetypical hero stories, as Jung posited, constitute part of the collective unconscious. ${ }^{809}$ They help us explain the unexplainable in narrative form and make sense of our existence and condition. This study necessitated a presupposition in the validity of Campbell's map of the classical hero narrative and Jung's assertion that archetypes are a tool for making meaning. However, there have been more recent studies that suggest people reconstruct meaning of past events and hero narratives and reinterpret those narratives by formulating new

\footnotetext{
${ }^{808}$ Joseph Campbell, The Hero with a Thousand Faces, Bollingen series (Princeton, NJ: Princeton University Press, 2004); Jung.

809 Jung, 155.
} 
interpretations of their environment in personal ways and construct visions of possible futures. ${ }^{810}$

These other fields of study, namely psychology and social psychology, contributed to hero studies literature and further illuminated Jung's ideas of the archetypes. George Goethals and Scott Allison asserted that humans have many types of heroes and create vivid narratives detailing the exploits of those heroes. The constructed narratives are linked to the archetypes described by Jung, conceptions of what heroes are and what they do. Heroes struggle and triumph and serve as powerful identification figures that motivate and channel personal development towards achievement and proper behavior. The struggle, or hero's journey, is an inescapable part of the human experience and is a recurring theme in virtually all human storytelling, including the earliest epic tales in history. Perhaps this is due to the fact the hero archetype reflects millions of years of evolution during which human beings struggled to survive. It is no wonder that hero stories demonstrate that humans across time and cultures appear to be enamored with the hero who suffers deeply to accomplish great and noble deeds. Heroes also help fulfill important physical, emotional, and existential needs. The transformative hero schema, which is particularly salient for this study, detailed visionaries who transform groups and themselves in such a way that their followers are inspired to become heroic as well. Goethals and Allison noted that there is significant overlap with what heroes and leaders do - they both transform followers, admirers, and those in their charge. This discovery lends credence to an important trend found in the responses of participants of

${ }^{810}$ Michelle Boone Carola Conle, "Local Heroes, Narrative Worlds, and the Imagination: The Making of a Moral Curriculum," Curriculum Inquiry 38, no. 1 (January 2008). 
this study. Groups and organizations may use heroes to survive and thrive at both the level of the individual and the collective. ${ }^{811}$

Campbell's schema or motif for the classical hero journey is recognizable for most people. In it, the hero comes from humble beginnings and goes forth on a journey into the unknown to conquer an adversary (physical or metaphysical), facing adversity along the way, and, upon ultimately triumphing over those trials, returns to society to share something valuable attained on the journey. "The hero is the individual who voluntarily faces the dragon of the unknown, cuts it up, and creates the world from its pieces; the individual who overcomes the too-long-senescent tyrant and frees the virgin mother from his grasp." 812 It may be the oldest tale told by humans and continues to be a framework through which people make sense of their place in this world.

\section{Review of Applicable Theoretical Frameworks}

Several key sociological theories frame the potential utility of hero narratives. Like topical literature on the pervasiveness of the hero archetype, these theories, while explained extensively in previous chapters, are summarized here. However, SelfEfficacy Theory is introduced below in this text for the first time, as it was most salient to findings uncovered during data analysis.

\section{Durkheim and Social Solidarity}

Durkheim posited that members of an organization rely upon each other and must communicate in order to accomplish organizational goals, requiring structure and cohesion. Durkheim asserted social life is only possible through vast symbolism, and I

\footnotetext{
${ }^{811}$ Scott T. Allison George R. Goethals, "Making Heroes: The Construction of Courage, Competence, and Virtue," in Advances in Experimental Psychology, ed. J.M. Olson and M.P. Zanna (San Diego: Elsevier, 2012).

${ }^{812}$ Jordan B. Peterson, Maps of Meaning: The Architecture of Belief (New York: Routledge, 1999), 309.
} 
argue that this applies on the individual, relational, familial, and collective levels of analysis. ${ }^{813}$ Rites, rituals, and myths represent some of the symbolic markers that indicate group membership and provide an emotional pull and sense of meaning for that membership. Group members often desire a sense of connection to the group's past in order to feel connected to the group's present.

\section{Halbwachs and Collective Memory}

Halbwachs argued that people make sense of themselves and their connection to the past through symbols, historiography, and biography. Collective memories, as Halbwachs explained, are those memories about an individual or event that are distributed amongst individuals within a population and serve as harbingers of culture. ${ }^{814}$ Sense-Making Theory

Sense-Making Theory explains the processes by which people attempt to understand ambiguous, equivocal, or confusing events. This theory includes the use of narratives and stories as metaphorical tools for creating a sense of meaning. It also addresses identity, a processes through which members of an organization construct and maintain identities on the individual, cultural, social, group, professional, or organizational levels. ${ }^{815}$ As psychologist Jordan Peterson detailed in Maps of Meaning: The Architecture of Belief, "The natural, pre-experimental, or mythical mind is in fact primarily concerned with meaning," not with objective reality. In the case of this study, hero narratives "must have emotional impact before it will attract enough attention to be explored and mapped in accordance with its sensory properties...." People do not need

\footnotetext{
${ }^{813}$ Durkheim and Fields, xlix.

814 Halbwachs.

${ }^{815}$ Andrew Brown.
} 
to know what things are simply for the sake of typology - they need to know what things are "to keep track of what they mean - to understand what they signify for our behavior." $" 16$ Making sense of the world around us is paramount for the human psyche. Affective Disposition Theory

ADT indicates that media and entertainment users make moral judgments about characters in a narrative, which affects their enjoyment of that narrative. This theory expands on the ideas of the archetypical hero and the hero's journey posited by Jung and Campbell. Those who read, listen to, or watch stories of exceptional individuals associate them with the hero narrative schema and develop expectations about how a narrative should unfold. That schema becomes a template representing a cognitive framework that helps narrative consumers organize and interpret information. ${ }^{817}$ $\underline{\text { Liminality and Communitas }}$

Liminality is a term that refers to a stage within a transformational process that occurs after initiates are separated from their previous status. It indicates a period of time in which members lack status as full members of an organization. The rituals and rites of passage that all members go through in order to gain that status, which are outlined in this study, are very much in line with Durkheim's arguments on social solidarity. The concept of communitas, or the incorporation of ideas about homogeneity and comradeship while in a period of liminality, are important for understanding how burgeoning members practice the development of social solidarity. It also illustrates how

\footnotetext{
816 Peterson, 3.

${ }^{817}$ Sue Ellen Christian.
} 
the Army may be viewed as a unique subculture, into which membership is earned through a transformational process that includes a period of liminality. ${ }^{818}$

\section{Self-Efficacy Theory}

Albert Bandura introduced Self-Efficacy Theory in 1977, in which he explored the initiation and maintenance of certain types of individual behavior. Self-efficacy, according to the theory, is a central component for goal setting, enactment, and attainment. ${ }^{819}$ This theory refers to an individual's belief in his or her capacity to execute behaviors necessary to produce specific performance attainments, or confidence in the ability for the individual to control personal motivation, behavior, and the social environment. One way in which self-efficacy is altered is through social-comparative information conveyed through vicarious modes of influence. ${ }^{820}$

\section{Methods}

To address the research questions, I conducted a qualitative study, and while I employed certain systematic Straussian (Anselm Strauss) techniques during data analysis, this examination, as seen in my reliance upon theoretical sensitivity, coaxial coding, and the use of outside data and theorem, was in keeping with the Glassarian (Barney Glaser) grounded theory tradition. ${ }^{821}$ The collection of data was performed through one-on-one interviews with members of a target population - Army ROTC cadets in a single university program. There were negatives and positives for choosing to interview

\footnotetext{
818 Victor Turner.

${ }^{819}$ Albert Bandura, "Self-Efficacy: Toward a Unifying Theory of Behavioral Change," Psychological Review 84, no. 2 (1977).

820 "The Explanatory and Predictive Scope of Self-Efficacy Theory," Journal of Social and Clinical Psychology 4, no. 1 (1986): 359.

821 Barney G. Glaser, "The Constant Comparative Method of Qualitative Analysis," Social Problems 12, no. 4 (1965); Anselm Strauss and Juliet Corbin, Basics of Qualitative Research: Grounded Theory Procedures and Techniques (Newbury Park, CA: Sage Publications, 1990).
} 
individually. Groupthink, social desirability bias, and performance group behavior bias amongst participants were minimized. There was potential for establishing greater rapport between myself and individual cadets, possibly resulting in richer and more authentic data. Additionally, it was likely that most cadets felt more comfortable participating fully without their peers present if their views are not seen as normative, particularly since some lines of questioning addressed their opinions of their peers. Furthermore, while I do have connections to the military and the Patton Museum, I introduced myself only as a Ph.D. candidate.

Because the site chosen is not a form of public memory relating to Patton, the risk of prestige bias was minimized in regards to questions about Patton. The careful framing of questions and my use of inductive reasoning also combated prestige bias.

Additionally, while prestige bias may have been a limiting factor in that cadets might have felt compelled to provide positive associations regarding questions about Patton and the Army's socialization efforts and methods, it seemed unlikely given their willingness to speak freely about his shortcomings. Because I was interested in the idiosyncrasies and peculiarities of the Army subculture, my sampling strategy was not a source of explicit bias, in my estimation. To address the potential for non-response bias stemming from cadets self-selecting into the study, I compared demographic and background variables of those interviewed with the total population of cadets at the institution and within ROTC at large. National and institutional ROTC data are carefully tracked and are publically available upon request from the U.S. Army Cadet Command headquarters. I cannot reveal the identity of the institution studied as part of this dissertation and cannot 
provide said data. Furthermore, I did not report background data regarding the university program in order to further protect the identity of participants.

The nature of the data collected was purely subjective by design - hero veneration is a subjective phenomenon after all. Who cadets considered heroes and why were matters of personal choice, as was their approach to institutional icons. For example, I asked how each participant defined a hero in their own words, and except for those who required a prompt from a dictionary, all subsequent responses were within that framework. I allowed volunteers to respond in their own terms, talk freely about subjects that arose, and encouraged the sharing of personal attitudes and beliefs. As such, participants shared authentic positions, as the evidence described below demonstrates. Those who took part in the study were surprisingly candid. There are many benefits of Verstehen, a term used by Max Weber to describe the need for "subjective understanding" or the ability to understand individuals or groups from the perspective of the observed. ${ }^{822}$ My goal was to discover how these individuals thought of heroes and what inspired them. However, the process by which I analyzed the subjective data was objective. I coded and analyzed the data concurrently with collection, the constant comparative method or coaxial coding, in adherence to grounded theory methodology. ${ }^{823}$ During the open coding process, I began to identify core theoretical concepts, developed tentative linkages between the core concepts and the data, and determined the central categories (relational and variational sampling). I analyzed data during and after each session in order to take advantage of new insights and focused my lines of questioning on

\footnotetext{
${ }^{822}$ Kenton Bell, ed., "Verstehen," in Open Education Sociology Dictionary, accessed July 2, 2020, https://sociologydictionary.org/verstehen.

${ }^{823}$ Barney G. Glaser, "The Constant Comparative Method of Qualitative Analysis," Social Problems 12, no. 4 (1965).
} 
those emergent themes (discriminate sampling during selective coding). When responses to questions became repetitive and no new theoretical insights were gleaned from the data, the findings were analyzed thematically to answer the central research questions.

During the process of coding I categorized the qualitative data for descriptive purposes. Organizing themes and subthemes and assigning them to broader concepts was the main task during this stage. Concurrently, I engaged in memoing, the process in which I recorded my thoughts and ideas that evolved throughout the study in order to organize my thoughts on emerging themes. Similarly, I used integrative diagrams to pull all of the details together and make sense of the data with respect to the emerging theory. Finally, to test the authenticity of my findings, I took each code, theme, and subtheme and randomly pulled transcripts, looking to see if support for those concepts could be found in those interviews. Then I reversed the process by searching through each transcript to see if a randomly selected code, theme, or subtheme was evident. This ensured that I did not overreach during data analysis by making generalized statements based on anecdotes.

The aim for this qualitative study, of course, was to meet theoretical saturation with the data. According to the grounded theory method, theoretical saturation is reached when no new or relevant data seems to emerge regarding a category, the category development is dense insofar as all of the paradigm elements are accounted for along with variation and process, and the relationships between categories are well established and validated ${ }^{824}$ Unlike sampling done in quantitative investigations, theoretical sampling cannot be fully planned before embarking on a grounded theory study. Specific

${ }^{824}$ Anselm Strauss and Juliet Corbin, Basics of Qualitative Research: Grounded Theory Procedures and Techniques (Newbury Park, CA: Sage Publications, 1990), 188. 
decisions evolved during the research process itself, although I reasoned that the phenomenon in question was evidenced with ROTC cadets. The nature of my sampling rationale, procedure, and data collection technique has grounding in prior research, namely by sociologists Anselm Strauss and Barney Glaser.

\section{$\underline{\text { Data Collection }}$}

Initially, I tested a modified prototype interview guide (questions regarding ROTC, for example, were omitted) with five college student volunteers enrolled at the same university as the cadet participants. I then modified certain prompts based on feedback. Data collected during the creation of the prototype was used only to inform and test the interview guide. Pretesting the interview guide also helped hone interview skills with a somewhat similar population to cadets.

The non-confining, generative questions (open-ended questions that generate other questions, new ideas, concepts, codes, etc.) that guided the study illuminated ideas that were unconsidered during the earliest stages of the open coding process. ${ }^{825}$ Anticipated follow-up prompts were used in the questioning to gather sought-after information. Of paramount importance was the fact that the data collected drove further data collection and analysis. The questions were intended to yield interesting details on the phenomenon under examination.

For the interviews, a semi-standardized interview guide (see Appendix B) was used to gather data that coincided with the coaxial steps of coding called for by grounded theory methodology. Data gathering was conducted on campus in a setting that provided privacy. Each interview took approximately 30-45 minutes and was recorded on a digital

${ }^{825}$ Anthony Byrant, Grounded Theory and Grounded Theorizing: Pragmatism in Research Practice (New York: Oxford University Press, 2017), 237-39. 
audio recording device. During each session following the interview, a short questionnaire (see Appendix C) was utilized to gather demographic and background information such as age, military affiliation and length of service, range of familial military affiliation, sex, college major, desired branch (legal, medical, combat arms, etc.), academic class, and prior service status.

The guide included a series of questions geared to uncover whether or not cadets had heroes, and if so, what types of individuals the respondents considered heroes; if and what they found inspirational about their heroes; and how they defined a hero generally, informing the utility of icons in transformational processes. Reflective questions tied attitudes towards heroes to the transformational process itself. Finally, the interview consisted of questions structured to reveal whether or not the collective memory of Patton existed within the group under examination.

I assigned gender-neutral pseudonyms for participants during the interview process. Therefore, in the analysis and discussion that follows, those pseudonyms were utilized.

Sampling

The Army ROTC program typically takes four years for the average cadet, making it one of the Army's transformational processes with the longest duration (the U.S. Military Academy also takes four years from initiation to graduation). As such, of all the instructors responsible for executing the Army's transformational processes, ROTC Professors of Military Science (PMS) have the most contact with students and therefore have the greatest opportunity to make a lasting imprint on them (basic military training is typically only eight weeks long). Therefore, ROTC was a logical program to 
study. The ROTC transformational process includes a series of military science courses, hands-on laboratories in which cadets learn basic soldiering skills, physical fitness, and marksmanship training. Additionally, cadets attend class sessions aimed at explaining the various aspects of the Army subculture. Most cadets attend Basic Camp on a military installation in which they are fully immersed into Army life. Before beginning their final year in the program, cadets also attend Advanced Camp in which they are tested on leadership and soldiering skills learned over the previous three academic years and are evaluated on whether or not they have been socialized into the subculture. The culminating cult, in Durkheim's terms, is a commissioning ceremony that is replete with symbolism, tradition, and heritage.

This study's sample included 27 Army ROTC Cadets enrolled at one university. Prior to the Spring 2020 semester, I received a list of email addresses from the university's Army ROTC program and a data set of nationwide population demographics of Army ROTC Cadets. The survey, conducted in 2019 by the U.S. Army Cadet Command's (USACC) Operational Analysis Division (OAD), included breakdowns of cadet demographics by school year, Military Science (MS) I-IV, the rough equivalent of first-year students, sophomores, juniors, and seniors. In January 2020, I invited all (n $\approx$ 100) cadets in the program through email who were over 18 years of age to participate. The interviews took place from January to March and were conducted on a first-tovolunteer, first-to-interview basis. I sent two reminders via email. Precedent for small sample size in qualitative work has been established in previous literature. For example, 
John Creswell argued 20 to 30 participants are adequate for thematic development in grounded theory methodology. ${ }^{826}$

I utilized a nonprobability technique in the form of purposive and theoretical sampling. While sampling began as purposive with individuals and an interview guide, grounded theorists analyze concepts, not populations per se. In other words, sampling was conducted on the basis of the evolving theoretical relevance of concepts. As relevant preliminary codes and concepts emerged simultaneously with ongoing data collection while utilizing the constant comparative method, questions refocused and narrowed to address the evolving theory. The initial sampling variation for the interviews was criteria-based (Army ROTC Cadets enrolled at a specific university) with a purposive type (young and in the midst of a transformational process) in that this criterion was a result of the research questions and the theoretical relevance of the study - that is, to address how people define heroes, how they receive and interpret hero stories, and how they use those stories to make sense of themselves in the context of a larger organization. The aim was to develop a theory about these phenomenon in the context of organizational transformational processes. Furthermore, I used what may be considered a neohomogenous sampling technique. While the sample was a diverse group on the individual level of analysis, they did share many characteristics, particularly their status as cadets and their commitment to the same organization and career. This allowed for depth and density in the data. To get volunteers, I asked the entire population of interest to participate in an interview that utilized a semi-scripted interview guide in order to enhance the authenticity of the findings.

${ }^{826}$ John W. Creswell, Qualitative Inquiry and Research Design: Choosing Among Five Traditions (Thousand Oaks, CA: Sage, 1998). 
The population of interest, Army ROTC cadets, is typically in their early twenties and is in the midst of a transformational process. Because of their age and their state of liminality, their attitudes regarding the research question allowed for an understanding of how individuals in the process of becoming soldiers and officers identify with the Army's history and heritage (including biographies) and how they use those stories. Because they are on the cusp of beginning their careers, the effects of those attitudes on the future of the institution are salient and the fact that they will be officers means those who stay in the service will someday shape Army policy. There were no participants interviewed under the age of 18 and none over the age of 35 (the cutoff age for admittance in the program). Participants' median age was 25 years, which closely resembled the age of cadets vis-à-vis the university and nationwide data. ${ }^{827}$

Some of the participants were classified as "prior service," meaning that they served as enlisted members of the military prior to their enrollment in college and ROTC. These individuals were unique and rich sources of data. Of the 27 Army ROTC Cadets interviewed, 11 reported already having served or currently serve in the Armed Forces; three have prior Active Duty experience, eight have experience in the Army Reserve or National Guard, and four of the latter are in the Simultaneous Membership Program (acting as contracted cadets assigned to a National Guard or Reserve unit). As indicated in Figure 1 below, this sample resembled variables taken from nationwide data. Of those who have a military affiliation besides their enrollment in Army ROTC, the median length of service was approximately seven years.

${ }^{827}$ I chose to not publish the age range as the high end might compromise the identities of older participants. See Army ROTC 2019 MS II, III, and IV survey results. 
Figure 1: Cadets with prior military experience compared across categories by percentage

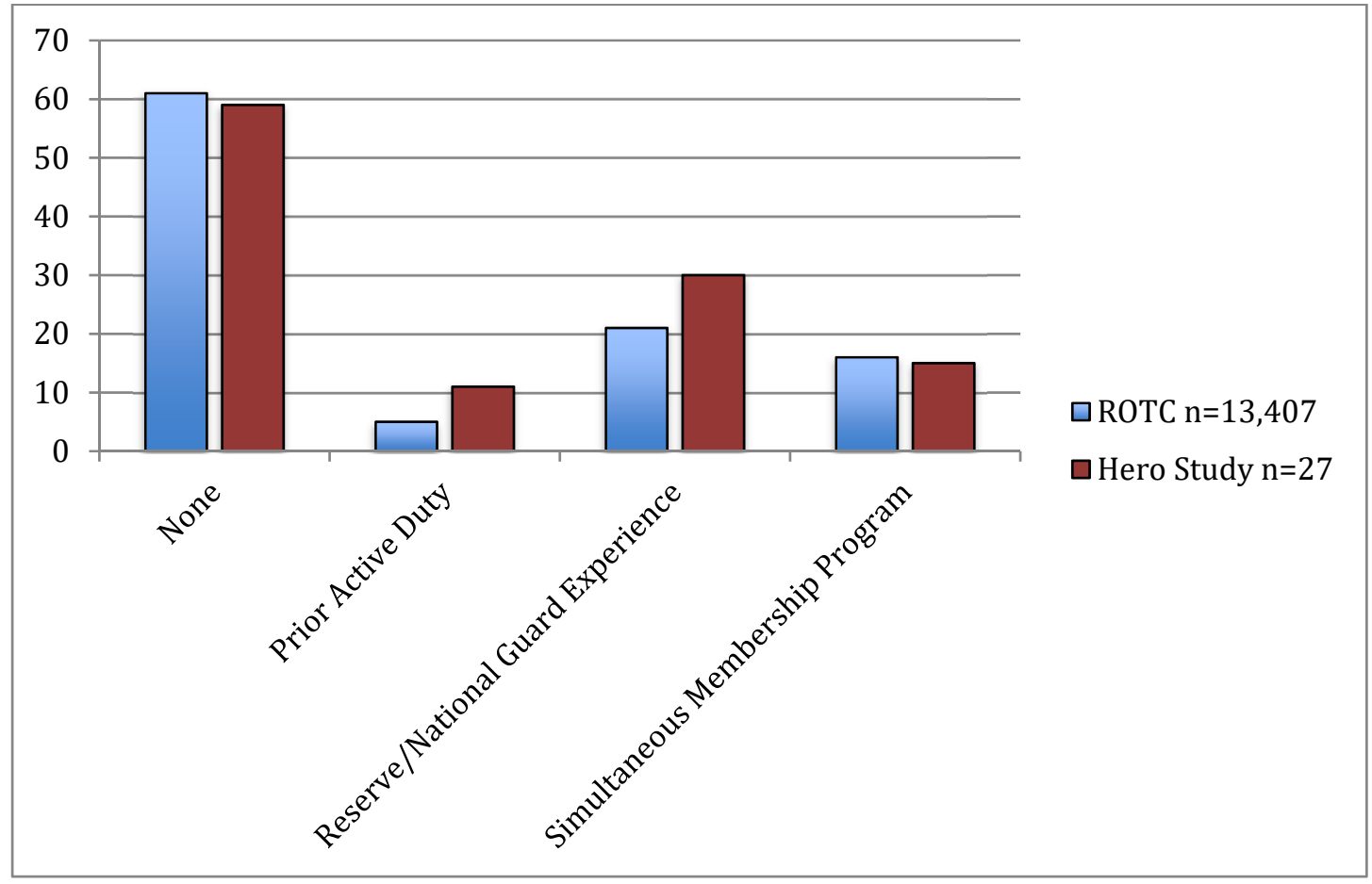

There was a mix of males and females but the numbers were skewed heavily towards males. However, for this study females were overrepresented compared to the demographics of Army officers ${ }^{828}$ but were on par with the Army ROTC population as a whole. ${ }^{829}$ Twenty males (71\%) and seven females (29\%) participated in the study. As indicated in the graph below (figure 2), this breakdown of participants by sex resembles the data collected by USACC OAD in regards to nationwide background data.

${ }^{828} \mathrm{Females}$ comprise approximately $17 \%$ of the Army officer population according to 2016 data. See "Army Demographics FY16 Army Profile," accessed June 8, 2020, https://m.goarmy.com/content/dam/goarmy/downloaded_assets/pdfs/advocates-demographics.pdf. ${ }^{829}$ In the 2019 nationwide survey of ROTC cadets, gender was measured by asking if cadets were male or female. 
Figure 2: Sex comparison across categories in percentages

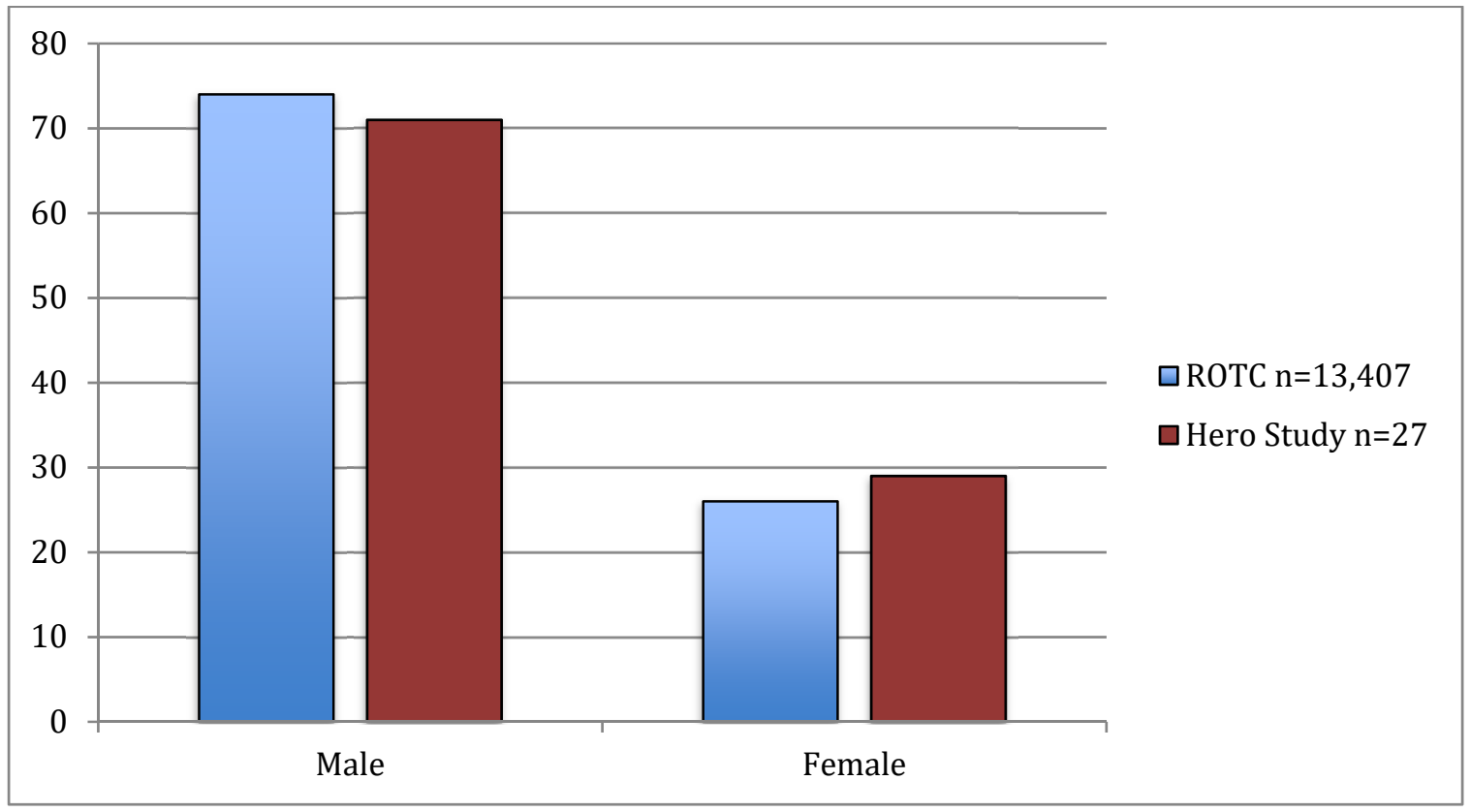

Although there were no first-year student (MS I) participants, those who did participate were roughly equally distributed between MS II, III, and IV; 10 sophomores $(36 \%), 8$ juniors $(29 \%)$, and 9 seniors and graduate students $(32 \%)$. This is notable in that MS I cadets are typically in their first year in the program, have not undergone any major transformational events (such as Basic Camp), and most have not made a firm commitment to continue. On the other hand, MS II-IV cadets typically have an idea of what lies ahead after at least one full year in the program and have attended USACC's Basic Camp. Most, if not all, MS III and MS IV students are contracted, meaning they are on scholarship and although they are not obligated to graduate and obtain a commission as an officer in the Army, most do so. ${ }^{830}$ MS IV cadets include seniors and graduate/post-baccalaureate students.

830 Cadets who accepted a scholarship, i.e. are contracted, are not full members of the Army. They may still drop out of the program on their own volition, however they have an incentive to continue. In some cases, those who drop out of the program after accepting a scholarship may have to pay some, if not all, of the scholarship money back. 
While not all participants had prior military service, most $(n=20)$ reported to have a familial affiliation with the military. Amongst the participants, four reported having a sibling, 10 had a father, six had an aunt or uncle, five had a cousin, and 17 had a grandparent who served or are currently serving in the military in some capacity. As such, the sample in this study resembled familial military affiliation data from the university and nationwide samples in some areas (siblings, cousins, and aunts/uncles) and were overrepresented in others (fathers and grandparents).

Figure 3: Comparison of most often reported family members with military affiliation across categories in percentages

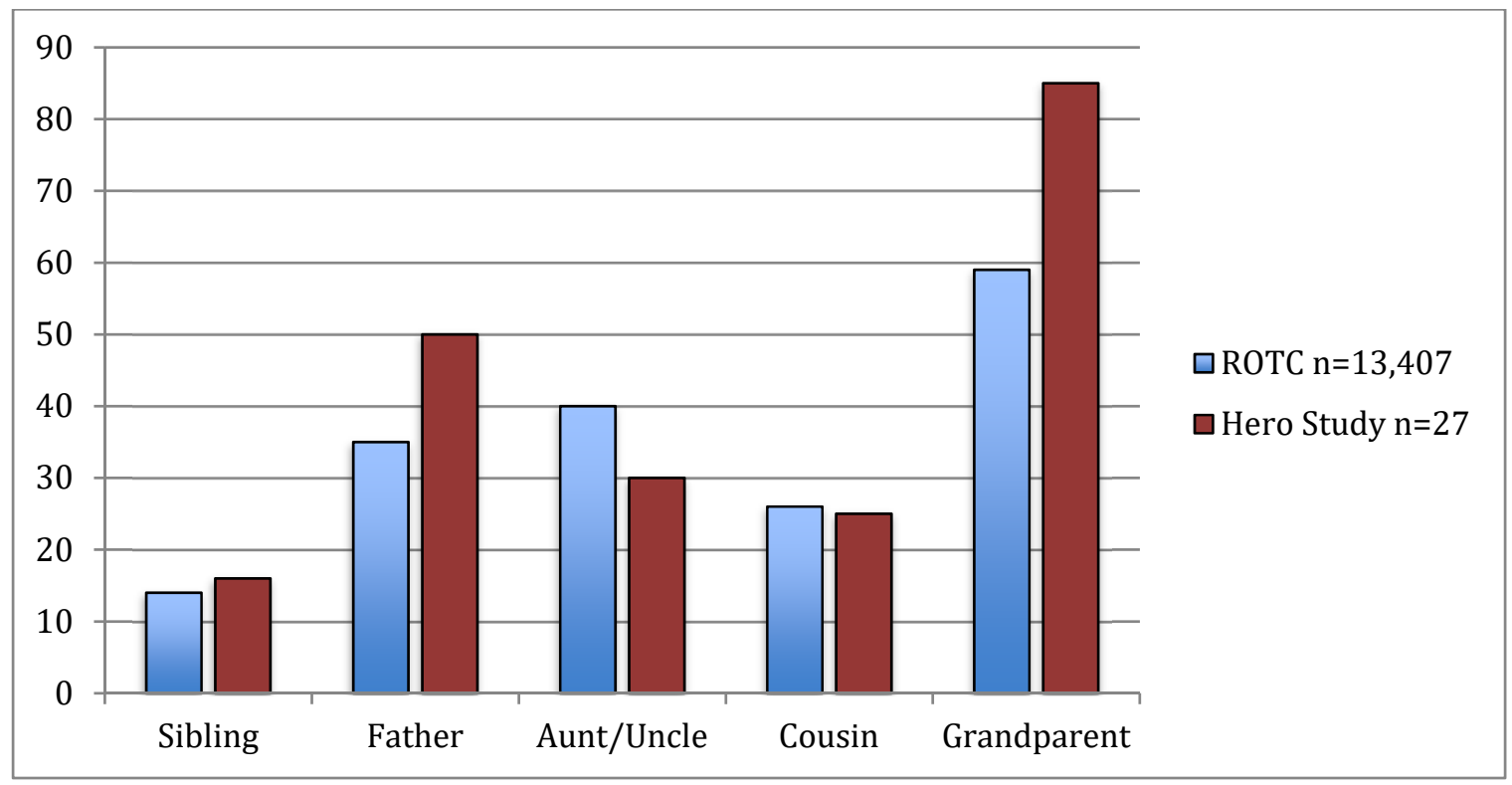

When comparing race or ethnicity variables of participants to the nationwide and university program data, volunteers for the hero study were similar. European Americans and those who reported two or more races/ethnicities who took part in the study $(\approx 80 \%)$ were slightly overrepresented when compared to the nationwide sample $(\approx 70 \%)$. Racial/ethnic minorities $(\approx 20 \%)$ were slightly underrepresented in the sample compared to nationwide ROTC data $(\approx 25 \%)$. Racial and ethnic variables of the study sample approximated the percentages in the university. 
Although this study took place at a single university and the findings may not be generalizable to the entire population of Army ROTC Cadets, nor do I make any claims as such, it is worth noting that certain individual factors provided for a reasonably representative sample. The cadets' age, year in university, interests, ethnography, socioeconomic backgrounds, and college majors nearly mirrored those of the overall ROTC population (over 20,000 nationwide). Furthermore, the university where the study took place centered in the geographic regions of the United States where the majority of ROTC programs are located (the Midwest, Southeast, and East).

\section{Data Analysis and Findings}

What follows are my findings and explanations of the phenomenon of interest (a grounded theory) using as much context and relevant details as possible.

Field research addressing the questions at hand revealed three phenomena regarding heroes. First, participants tended to center narratives of heroes on their sense of self. Three subcategories to this phenomenon address that process: whom cadets found inspirational, how they connected to those narratives, and what these individuals did with those stories. Secondly, participants used hero narratives to help make sense of their place in a broader context. Several subcategories related to this phenomenon explained this process as well. Participants used institutional icons to help in the Army's socialization process, including adopting a shared heritage, understanding the organization's value structures, and going through a process of differentiating themselves as in-group members by comparing their newly adopted value systems to those of outsiders. And finally, there was evidence that the collective memory of Patton is very 
much still in existence within the Army ranks, albeit very different from the messaging those memory workers discussed in previous chapters hoped would be internalized.

Cadets in the sample described these cognitive processes as utilitarian in nature: they aligned hero narratives with their career goals and used those narratives to help achieve their aims. By whom they were inspired, what inspired them, how they came to know their hero's stories, what they did with those stories, and how they envisioned their place in the institution were pragmatic and well-reasoned choices. After considering each of these themes, the data taken from the interviews was interpreted in light of institutional goals: if the Army maintains heroes and their stories, how can these phenomenon be leveraged to gain buy-in, develop esprit de corps, and socialize new members in order to increase the effectiveness of the organization to meet its given mission: for the Army, fighting and winning the nation's wars. ${ }^{831}$ Analyzing and interpreting data in the context of organizational or institutional goals may open the possibility for other organizations to use the grounded theory described in this chapter, the "Transformative Hero Model." If an organization has goals of increasing effectiveness or profitability, they may use this model to gain social cohesion and unity of purpose, two factors that have been empirically demonstrated to increase organizational effectiveness. ${ }^{832}$

\section{Centering on the Self}

Who Cadets Found Inspirational. Specific terms needed to be defined early in the process. I asked participants to define the term hero and if they had anyone they considered a hero. Although most definitions resembled each other I introduced the

\footnotetext{
831 "The Army's Vision and Strategy." https://www.army.mil/about/. Accessed September 11, 2020.
}

${ }^{832}$ See Chapter VIII, footnote 717 for studies that address social cohesion and unity of purpose. 
prompt "does anyone inspire you?" earlier in the conversations. Responses became much more nuanced and all of the participants reported to have a hero, even if they had difficulty defining what the word meant. For the 12 participants who were unable to define the word hero, as an additional prompt I utilized Merriam-Webster's definition as an example, which is a person who is admired or idealized for courage, outstanding achievements, or noble qualities. ${ }^{833}$ Answers to this query garnered two different but related categories of responses, what I coded personal heroes and "extrapersonal" heroes. I define personal heroes in the study as those who individuals know personally or have a close interpersonal connection with and "extrapersonal" heroes as those that individuals do not have an interpersonal connection with but share some sort of similarity. Considering a concentric circle diagram with the self as the center circle, personal heroes form the circle closest to the self and extrapersonal heroes are an outer ring (see Figure 4: The Transformative Hero Model).

Personal Heroes. Personal heroes tended to be the first examples given in responses during the interviews ( $\mathrm{n}=17$ ), highlighting their importance to the individual. They were typically family members; parents, grandparents, siblings, aunts, and uncles. Very often, these family members had a tie to the military, often through past service. Other personal heroes currently serve. For example, Jamie considered a family member a hero, although the stories learned about him were second hand, and contained echoes of Campbell's hero journey schema.

He was a Korean War veteran. He got a [Prestigious Medal] for saving a bunch of Marines they were with. They were attacking a hill and so like, as a kid, you're like, that's badass. He's doing some cool shit, he's in there saving people. I want to be like him. But as I grew up I learned more about him and I hear about him from my mom and my grandmother and stuff. I learned that he was really poor growing up and worked hard his whole life. He got a job working in a zinc mine

${ }^{833}$ Merriam-Webster Online, s.v. "hero," accessed January 19, 2020, http://www.merriamwebster.com/dictionary/hero. 
and worked up till he was like a foreman. Then he built a house for his wife and his kids. And he just kind of worked hard his whole life to build a life for him and his family. That's just something that I look up to.... He was respectful to both his family and people he didn't even know.

Jamie's family member clearly checked some of the markers of the classical hero motif: he came from humble beginnings, faced adversity and overcame challenges, and came back to his civilization to share what he learned: the value of hard work, respect, and responsibility. Applying ADT to this scenario allows one to see that Jamie, while intrigued by a family member's heroics during combat, enjoyed the narrative more when later discovering how the narrative fit into the hero journey schema. This theme was evident in each of the interviews while discussing personal heroes.

As another example, some family members, such as Sutton's mother, demonstrated courage in other ways and was attracted to her story because it too fit the hero journey model. Sutton's mother "came over from [another country] and she just left everything she knew and started over from scratch here.... I was just like, all my family sacrificed so I have something [better]. That was my inspiration." Others' personal heroes were pastors, former teachers, work associates, or military member mentors, especially for cadets with prior service experience. Sam, a self-identified Christian, reported that a pastor "helped me out a lot in my faith, he's just taken a lot of time and he likes to watch people grow in their faith. He's sacrificed a lot of time to be with me and other people he's helped along the way. He's really inspired me." Kris considered a former unit readiness non-commissioned officer $(\mathrm{NCO})$ a personal hero. "His convoy got ambushed when they were deployed and he personally responded, got out and engaged the enemy at really close quarters...[he was] not afraid to put [himself] in dangerous situations to protect others." 


\section{Extrapersonal Heroes. Ten participants first detailed narratives of extrapersonal}

heroes during the interviews. For participants, extrapersonal heroes shared some type of similarity, although they did not share a personal relationship, and the stories from which they gained inspiration fit the hero archetype first posited by Jung, detailed at length in Chapter IX. For instance, Val, who hoped to become a medical assistant, gained inspiration from

an Army [physician's assistant] who got a Silver Star in Afghanistan. Christopher Cordova. Basically their COP [combat outpost] was taken over and completely overrun, even the battalion aid station...his medics got hurt too, but prior to that all the training he did with them, preparation, thinking ahead, and even when it went down, he did things he was supposed to and went above and beyond.... So when you ask me what do people do who inspire [others], honestly, I don't want to see someone put on a pedestal necessarily, but someone that's, like, easily connected to.... Then as...something that I want to do, he did these really awesome things. He went beyond his scope of practice. He did stuff that he wouldn't brag about once, just did his best to save lives.

Ellis, who grew up doing gymnastics and playing baseball, admired the skill of and gained inspiration from Samuel McCullock and Derek Jeter, two notable athletes in their respective sports. Others, like Briar, connected to heroes with a shared sense of place. Briar gravitated to the famed story of a Medal of Honor recipient who was from the same state. Whomever participants reported as extrapersonal heroes, they all tended to choose those who they were able to identify or connect with on a personal level in some way and tended to connect with those who fit Campbell's monomyth of the hero's journey.

When thinking of military heroes, 21 cadets responded that the stories of company-grade officers (lieutenants and captains) were most useful due to their relatability. Julian's response is representative of most answers:

Let's face it, a lot of times, more so than not, we're not going to make that general officer level... or field grade officer. So I would rather...yeah, before this is what they did to get that general or field officer rank, you also have to understand, now I need to know how can I become a good lieutenant or captain. Because that's first. I gotta knock out these ranks before I can even get to dreaming about that. The usual average is what, nine to ten years before you even become a field grade officer? So I got a decade before I really even need to start thinking about, hey what were some of those good field grade officers or those generals doing? So I want to know how 
these guys stood out as a captain. How he stood out as a lieutenant before I even want to focus on that. You gotta crawl before you walk.

This theme cut across all categories of cadets; gender, age, prior service experience, time in the program, and ethnicity/race. However, this is not to suggest that the stories of well-established heroes in the Army were not well received or were not useful in any way. For these cadets, their concerns were immediate and they saw company-grade officer hero stories as more relatable in the short term. When prompted whether or not the stories of icons from when they were company grade officers could be inspirational or not, an overwhelming majority answered in the positive.

Although making connections to personal and extrapersonal heroes was important, racial, ethnic, or gender similarities with those heroes were not particularly germane, especially with male participants. Both male and female cadets nearly unanimously reported that heroes of any background were or had the potential to be inspirational to them on a personal level. Although there were no racial/ethnic minority female participants who reported that biological sex was a determining factor, all white female cadets indicated that biological sex was at least partly a determinant in whom they found to be heroes. One cadet replied that race was of no consequence when seeking inspiration, but it did help from a recruiting standpoint for MS I cadets who have yet to make a firm commitment to the Army. What was most salient about hero stories were the positive models of behavior they demonstrated in their actions.

Learning About Their Heroes. How cadets connected to their extrapersonal heroes was as important to understand as from whom they gained inspiration. They tended to learn about their extrapersonal heroes through various mediums that include videos, movies, documentaries, podcasts, and social media. Although not explicitly 
asked whether they did or not, approximately $75 \%$ of respondents volunteered that they do not read extensively. Barry indicated, "We don't like reading. We get distracted. We get distracted very easily. I know I do. We have our military history books and we just...it's so dry and you either fall asleep or you go on twitter or something." Even reading interpretive panels displayed in public places, such as in the hallway of the ROTC building where participants attend classes, were not effective for over half the cadets interviewed. Ellis indicated that "we see all these generals and all these quotes, a lot of it is, who gives a shit factor. This guy was a general during the war. Great. I see people like him on a daily basis....people my age don't know who the $25^{\text {th }}$ President was. Why would they care who the general in the Revolutionary War was?" One study suggested that there are no statistically significant effects on comprehension between reading, listening, or a combination of both. For this examination, the issue seemed to be one of interest for some, but not all, cadets. ${ }^{834}$

During their time in the ROTC program, all cadets across the country take a staff ride (an Army term for field trip) to a local battlefield as part of the transformational process. During the staff ride, cadets are assigned a part to play of an individual who took part in the battle and at certain places are expected to brief their peers on the actions that took place there. Galen, like several others interviewed, indicated an interest in this particular program and valued it over reading. Yet Galen perceived a lack of interest with others. "Obviously you have some people who kind of just glanced at it and their part wasn't too exciting but the people who are interested really went into depth.... If you can really get yourself involved in the same mindset and in the same place

\footnotetext{
${ }^{834}$ Barbara M. Calhoun Beth A. Rogowsky, and Paula Tallal, "Does Modality Matter? The Effects of Reading, Listening, and Dual Modality on Comprehension," Sage July-September (2016).
} 
geographically, it's going to be a lot more powerful than reading out of a textbook...."

\section{Similarly, Noel stated}

This generation is more technology-based, more visual just because of all of our screens and stuff, something like that. If you take the Battle of the Bulge and you can move [graphics and images] around but then you can incorporate individual stories but through the mechanism of seeing where the line moved and because of why, that's definitely a good idea. Just handing us a paper about how Eisenhower led the D-Day invasion, that doesn't hit us. Those stories of a second lieutenant leading in Vietnam, that stuff is easily connectable, we can resonate to it.

While responses to what types of mediums cadets use to consume information about inspirational people varied, even those who do enjoy reading reported to enjoy other mediums as much or more. Additionally, attitudes towards museums and historic sites were either positive or lukewarm - none were negative. However, treating these types of mediums merely as an extension of the classroom had a neutralizing effect on reception. In the context of stories of inspirational figures and their role in the centering of the self, treating these mediums as a battlefield lessons learned activity did not fully allow for personal connections to be made, or at least missed a prime opportunity to gain interest in the subject matter. Participants required a way to personalize and internalize those stories and without a mechanism with which to view themselves in a given situation, interest waned.

Connecting to Narratives. How cadets related to their heroes was a major theme that emerged in the data as well. Perhaps due to a lack of trust in institutions or because of their lack of relatability, icons that were once put upon metaphorical pedestals seemed to be of little immediate use for many $(n=25)$ cadets. ${ }^{835}$ What the interviews suggested is that these individuals tended to connect more with humanized versions of hero stories. If heroes are viewed as tools to aid with introspection and mechanisms against which

835 "Confidence in Institutions," https://news.gallup.com/poll/1597/confidence-institutions.aspx. 
humans measure themselves, as Jung's archetypical hero model argued, then translating hero stories to be more relatable by depicting those individuals as human beings rather than demigods was helpful for participants. By examining their flaws along with their successes or incredible feats, cadets were more easily able to relate on a personal level and develop a sense that they too could do similar things as their heroes, a key tenant of Self-Efficacy Theory. What mattered was scale. Although none of the cadets indicated that they believed they could reach the same level as the likes of iconic greats like Patton, they did see themselves taking similar paths to a certain degree and successfully leading others at a lower level by adopting some of the characteristics of those icons. Leading an entire army was not conceivable at this stage in their career, but applying some of the tenants demonstrated by icons to a platoon was, and they gained confidence when doing so, another aspect of Self-Efficacy Theory. Perhaps this is an additional explanation for why stories of company grade officers resonated with them.

As they did with personal heroes, the manner in which they internalized those stories was very much in keeping with Campbell's monomythic hero's journey narrative, especially as it pertains to the classical hero's fatal flaw or the overcoming of adversity. For example, Dallas stated that it was best to "think of heroes as people with flaws. If you put them on a pedestal you're going to think that you can never achieve anything." For Taylor, "if you put them on a pedestal and they seem like they have no faults, it seems like what they are is unattainable." Avery stated that the "humanistic way of looking at your heroes...it's almost inspirational to me because no one is going to be perfect" and was able to set a course by focusing on the things those heroes did right and modeling those. Avery's statement demonstrated one of the theoretical models of 
behavior outlined in Self-Efficacy Theory: prosocial behavior, or those behaviors deemed to be acceptable to the collective, is negatively correlated with moral disengagement, such as avoiding responsibility. Similarly, Oakley, who had some understanding of the Patton story, indicated that

I don't know what any of his faults were off the top of my head but I know that he was this godlike figure; at least that is how we view him today. And you know, he was a ballsy general who did a lot of stuff. Really raced to Berlin. I definitely think that now we are talking about his faults, and he is still a household name and people still know him, I definitely think that showing that he has faults, to let us know that he's still human and not some demigod, it definitely helps boost his popularity.

Humanizing the stories of heroes, in the words of Sutton, made it easier to make a personal connection and allowed for building confidence and the belief that they too can overcome adversity (Self-Efficacy Theory). "I think you kind of forget that they are just like you and me. That they put their pants on the same way." Whatever it was that placed those individuals on a pedestal in the first place, however, outweighed those flaws.

Overcoming adversity or flaws is a key characteristic of both the hero's journey schema and Self-Efficacy Theory and may be accomplished in part after gaining inspiration from stories of heroes during the sense-making process. In an MS II class assignment, cadets choose a leader from a list and present their findings on that individual for the benefit of the group. ${ }^{836}$ Kelly chose Lieutenant Colonel Hal Moore, the commander whose battalion was surrounded by North Vietnamese troops at Landing Zone (LZ) X-ray, depicted in the book and movie We Were Soldiers Once... and Young. "I've seen the movie about a dozen times. I think it's just a really good story against the odds." Galen stated that it is important for "you to leave the village, go out, do the hero's journey, and then bring back whatever that is to your civilization. Archetypical stories

836 "MSL 201 Leadership and Decision Making Lesson 06: Adaptive Leaders in History ROTC Writing Program Homework Assignment: Written Essay and Briefing." 
are archetypical because I feel like it's universal.” Indigo's personal hero was a family

member, a marine in Vietnam who

went overseas and got sprayed with Agent Orange and all that shindig and he came back and got diagnosed with cancer. But his attitude and everything, how he treated his family was very different from the stigma of his time. And he kind of changed that pattern for it. And...my mom and dad were always working so we would go over to our grandparents' house a lot.... And he helped develop like certain ideals and certain ideologies and beliefs that run in our family. He was just very... he was a good person to look forward to and be in common to, like [to] idealize.

The hero's journey narrative and the incorporation of prosocial behaviors were particularly salient to these cadets, especially as it pertained to their personal heroes.

Unsurprisingly, what cadets viewed as inspirational closely aligned with the Army Leadership Model. After all, they were aspiring to become Army leaders and have been undergoing the institution's transformational process for over a year, all while being socialized with the Army's normative behaviors and belief systems. The Army Leadership Model consists of three characteristics (intelligence, character, and presence) and three attributes (leads, develops, achieves). It goes without saying that cadets' extrapersonal heroes achieved prominence for some act, and for many, their heroes were leaders or individuals who demonstrated one or more of the Army Leadership Model's characteristics and attributes for reasons of relatability. The traits of a hero most commonly reported regarding a leader's character, or prosocial behaviors, were loyalty (or dedication), moral courage, and selfless service (or sacrifice); all part of another Army belief system, the Army Values (loyalty, duty, respect, selfless service, honor, integrity, and personal courage). Participants also indicated that the development of others, or people who were caring, encouraging, and supporting, were inspirational aspects of their heroes. Empathy (another subset of a leader's character, along with the Army Values) also had inspirational value and played a role in determining who their heroes were. Cadets valued heroes with intelligence, namely those who are/were 
experienced, skilled, and innovative. ${ }^{837}$ Overall, the motivating factor that participants used to connect to heroes were prosocial characteristics that they want to use to model themselves after, especially as they learned about the art of leadership. Group, racial/ethnic, generation, or sex were non-factors in this corollary.

Using Hero Narratives. Humans develop themselves through modeling by learning from the past experiences of others to help regulate their behavior, coinciding with the need for self-fulfillment or self-actualization. Within the context of an organizational subculture they seek out individuals from whom they may learn something about their chosen careers. Within the ROTC ranks, there is evidence that this idea has some merit, as seen in the data taken from the 2019 nationwide survey of cadets. When asked if they have a cadre member who they consider a mentor, of the nationwide respondents $(\mathrm{n}=8,951)$ who were in MS III and IV (juniors and seniors), $66 \%$ responded "yes." For the same question, the number of respondents enrolled at the university in question who responded in the affirmative was approximately $10 \%$ lower than the national response rate. It is not clear if those who did not have a cadre member mentor sought one. MS II students (sophomores) nationwide were asked a similar question: Do you have an Army officer that you consider a mentor? Of those who answered the survey $(\mathrm{n}=4,456), 70 \%$ responded "yes." The same percentages held when asked the question in relation to a member of their ROTC cadre, a relative who is/was an Army officer, a family friend who is/was an Army officer, or someone else in their lives who is/was an Army officer. This indicates that the majority of Army ROTC cadets across the nation sought mentorship from other people and the percentage of those who did increased as

\footnotetext{
${ }^{837}$ For further explanations of the Army Leadership Model and Army Values, see Field Manual 6-22:
} Army Leadership (Competent, Confident, and Agile). 
they neared graduation and commissioning. ${ }^{838}$ For purposes of this study, it suggested that individuals in a liminal phase of their membership into an institution were open to guidance and direction from more experienced and knowledgeable members of that organization or subculture. While mentors are typically alive, this data correlates to the idea that the majority of Army ROTC cadets may be open to learning from past members of the same ilk as their mentors. ${ }^{839}$

As burgeoning Army leaders, about 90\% (n=24) of the cadets interviewed sought ways to measure themselves in their development. They needed aiming points, or goals to strive for. Self-Efficacy Theory lies at the heart of Social Cognitive Theory, which emphasizes the role of observational learning and social experience in the development of personality - an individual's actions and reactions are influenced by the actions that individual observed in others. The use of hero narratives as a means to develop a sense of confidence, as reported by participants in the study who traverse the liminal experience of the institutional transformational process that is ROTC, is evident. As leaders in training, participants in the study reportedly found potential and value in tailoring those narratives in more personable and humanistic ways and make connections to and gain inspiration from their heroes and the Army's symbolic representations of the ideal, especially with iconic leaders from the past. Institutional icons, symbols of the ideal as argued by Durkheim (see Chapter VIII), served as aiming points for the cadets interviewed. These icons were heroes chosen for them by the institution and illustrated what the collective and/or the organization values, much like Durkheim's concepts of

\footnotetext{
${ }^{838}$ In the Army it is customary for individuals to seek out their own mentors. Therefore, if individuals did report having a mentor, it was surmised that they sought those mentors on their own volition.

${ }^{839}$ See 2019 MS II, III, and IV survey results.
} 
totemism seen in forms of religion - former members of a group established the collective's totems. Simultaneously, those icons whose places are secure in the Army's pantheon of greats served as tools for cadets to measure themselves against. This idea works much like Durkheim's interpretation of religious expression found in totemic symbols, or the visual representation of beliefs and opinions. Briar, one of the participants in the study, explained that these iconic Army heroes "are role models. Many young lieutenants and cadets study those even today. Without them they would have nothing to base off of." Indigo believed that icons give a face to the goal, giving those aiming points a sense of concreteness. Leaders can "look at those icons... and think, I can be something great for my country and I can do something beneficial and helpful. You need to have something to look at and look forward to, try to shape yourself around or realize why you are doing something." Dallas responded

I think they probably bring an idea of what you can do that's right and also what you can do that's wrong. Everything that happened was a direct cause from their leadership. Whether good or bad. If you just completely take them out, you don't know why things happened. I think it's important to admire the things they did well but then taking in the things they did [poorly]. But you have to talk about them in order to understand where that is.

According to about $92 \%(\mathrm{n}=25)$ of participants, an Army without icons, then, was an aimless Army. When asked if they could imagine an Army without heroes, Barry responded, "Oh my God, no. It would be like...you have to know your history in order to keep moving and not make the same mistakes, or like, have somebody to look at.” Landry explained the existential nature of institutional icons. "We would almost have no standard. Which is a bit dramatic, I realize that, but also it's not.” For Landry, symbols representing standards were more than proxies - ridding the institution of symbols was to rid it of standards. Regarding the issue of scaling mentioned previously, the cadets understood, in the words of Finley, "you know, trying to put people up on these 
pedestals, say, this is the goal. You're probably never going to reach it, but this is the goal." While using icons as aiming points, participants were realistic in how they viewed organizational heroes. By scaling down or distilling lessons derived from narratives to fit into their current realities, they were able to take away something from the stories of icons and use those in their personal development at a much lower level in the military hierarchy.

Twenty-six cadets utilized heroes to create a sense of self-identity through the process of selecting personal and extrapersonal heroes who have traits or qualities they aspire to model, translating hero stories through a process of sense-making in order to identify with those individuals, humanizing the narratives of iconic heroes in order to connect with them, and using institutional heroes as aiming points or measuring sticks. Self-efficacy reflects an individual's belief that they can perform well and their ability to perceive and interpret their own existence from clues they receive from external sources, according to the related Self-Concept Theory. Successes and failures are closely related to the ways in which people learn to view themselves and their relationships with others. For most cadets, due to the nature of their chosen profession, the sense of self was tied to national identity, such as Ripley, for whom "just having those narratives help from some of these big events...having a national identity is very important, even as we reshape it and we try to wash it clean, it is still there. We need to know it." For Landry, heroes were 'those that I want to be more like or think about if I'm in a situation, what would I do about this or how should I react." For Hayden, heroes were on pedestals "for a reason. The great things they did.... It's something to aspire for." For these cadets, hero stories were not merely entertaining. They were inspiring narratives they internalized as they 
navigated through their journey into the very real, very harsh world of the military and warfare. And they helped to show what they could become and gain the confidence to do so as they borrowed from the past to create a personal identity. Not lost on participants was the fact that institutional icons were valuable sources of information as they learned the cultural norms and belief systems of the organization of which they were becoming a part. Heroes helped them make sense of how their newly forming identities fit into a broader scheme and gave them confidence to do so.

\section{Making Sense of Belonging}

The Socializing Process: Adopting Shared Values and Heritage. Literature suggests that task and social cohesion are key factors that make military organizations more effective. ${ }^{840}$ As the Army attempts to foster unity of purpose and belongingness to the group in its transformational processes, cadets used institutional icons to determine what the Army leader prototype looked like in order to help them understand their place in the organization. This points towards the individual needs for security and belongingness. As posited in Turner's concept of liminality, these members have yet to gain full membership into the Army and must go through a series of rituals or rites of passage to gain membership. Durkheim also understood that these rites were symbolic interactions that solidified group identity. Although not all participants were personally interested, all twenty-seven understood that knowing organizational history was important because not learning it risked the chance of being ostracized. Barry stated, "It's important to know, but just because of the culture." Ellis detailed the positive effects hero stories have on social cohesion as well:

${ }^{840}$ MacCoun; van Dijk. 
I think it's really cool knowing that I'm going to be part of an organization that's been around for [246] years and we fought in all these different wars. Some of which were not really good wars to be a part of but it still is the history. I mean, I'm going into the organization that George

Washington was part of. So that's what I appreciate about it.

Jamie echoed these sentiments: "I definitely think that it would give a feeling, a sense of belonging." Hero stories provided a centrality of purpose and illustrated the organization's hierarchy of values. For example, Kelly indicated that

When somebody declares a hero, they declare that hero based on what's in their beliefs. And Big Army, this guy General Patton, based off what he's done and that aligns with what the Army thinks is good or beneficial to people, for a new member coming in, they see this hero that the Army's declared, [they know] that is what is valued by the Army. And it kind of sets expectations in that new member in what course or path they choose to do good in the Army because you know the hero has portrayed that.

Similar to serving as personal aiming points for individual development, cadets used icons as symbols that represented the ideals and values of the Army, helping regulate their behavior to fit those norms. Durkheim and Halbwachs argued that aspiring members who did not share personal memories of a collective's past had the ability to gain membership through the adoption of belief systems played out symbolically, and a group's collective memory, as demonstrated previously in discussions on public memory, are represented in a multitude of ways. As cadets internalized messaging regarding the Army's normative behaviors illustrated by its icons, they began to adopt a shared sense of heritage and purpose. Hayden responded, "To say that you've been in their shoes, in a sense, yeah, it's a way of carrying the torch." Another cadet indicated that hero narratives provide a picture of "this is what we do, this is why we do it, this is our greater goal.” Reading an organization's mission statement is one thing - understanding it through a story, continuing those traditions, and passing them on to subsequent generations is quite another. 
Institutional icons helped provide structure by illustrating abstract concepts outlined in the Army's belief systems and norms previously discussed (the Army Values and Army Leadership Model) and demonstrated to new members what the organization's standards for model behavior are, thereby providing a framework for understanding the institution to which cadets will soon be a part. As Sense-Making Theory posits, individuals use narratives and stories as metaphorical tools to make meaning of their existence and construct individual, cultural, social, and collective identities. This idea became evident in the interviews. With only three exceptions, participants reported that hero stories helped illustrate the organization's ideals and made them understandable. Hayden indicated that using icons to illustrate abstract concepts was "kind of a derivative of them inspiring [us] in a way. But they highlight our Army Values to not be too cringy about it." Kelly agreed.

One of the things we do in our MS III class, we talk about attributes and competencies of new leaders. It's not the Army Values but it's the same concept. There's a big list of words that are pretty abstract concepts.... Yeah, you can say somebody is innovative but prompt us with why. Yeah, I think the why is more important than just the word. You can use heroes and theirs stories to provide the why for those types of words.

“Othering” Themselves. One particular way in which participants began to define themselves in relation to the larger organization, understood through the lens of Sense-Making Theory (and the psychological need for belongingness) as making meaning about their status as in-group members, was by comparing themselves and their adopted subculture to their generational peers in the broader public. Victor Turner described how in-group members preserve their adopted identity against out-group members, protect members' way of life from outside threats, and renew "the will to maintain the norms on which the routine behavior necessary for its social life 
depends." ${ }^{\prime 41}$ This was particularly true with the way cadets viewed institutional icons.

Take, for instance, Noel's comments:

I just don't think that this generation is very trusting of authority figures and stuff. So my grandfather probably idolized MacArthur and Eisenhower because they were tops, but this generation doesn't trust the government as much as previous ones do. [They] don't respond to authority as well.

Participants' heroes differed from what they perceived out-group members' heroes tend to be. Rather than Internet and social media sensations, athletes, celebrities, and politicians, these cadets looked to family members (especially those with military ties) or contemporary and historical military figures for inspiration.

Even the medium through which out-group individuals consumed information about heroes and who they chose as heroes was a source of consternation. As Dallas reported, while smiling, “Oh yeah, social media being something now, people admire TikTok stars or like YouTube or whatever it is." Finley echoed the same sentiment: "A lot of people have sports people as their heroes or movie stars and stuff like that. I don't watch sports or movies." Sam noted,

A lot of people look up to celebrities. They get famous for doing nothing. Maybe my generation...I have a negative view of them. The people they look up to, they didn't try the hardest. They cheated the system. Somebody got rich off of stocks. Or headline for some get rich quick guy. Not to say nobody looks up to hard workers. But most don't.

Most participants also recognized that military history is not popular amongst some of their peers. Their perception of their cadet peers indicated that attitudes lie somewhere in between those who are incredibly invested in the Army's heritage and those who could not care less, with the determining factor being how invested a cadet is in making a career of the military. Blake perceived that "I don't think kids nowadays buy into it as much as my generation would have. They are more about themselves and about

${ }^{841}$ Victor Turner, 110-111. 
their social cliques and stuff like that, not so much about the past I guess you can say."

Harper noted that books are not exactly the best way to reach most of his peers.

Every time Netflix comes out with another [history] series there is a lot of interest because they make it realistic. You're not just reading a book about it. Especially going to school with this generation versus mine, and that's only a few years difference. The older ones that are my age range, they are on my wavelength. Some read. But these? Not at all, comparatively. It's a huge difference. I've always wanted a textbook. I highlight it. Pay more attention to it.... As far as my studying is concerned, book. All day, every day. When you have to lug weight around, it adds greater weight to your education.

Investing in the profession of arms through a robust reading regimen is pushed at the

highest levels of the Army. ${ }^{842}$ Yet there is a real danger that many in the newest

generation of officers will not take advantage of the years and generations of wisdom

gained through toil and trauma. It the candid words of Landry,

I think...thinking of it [history and heritage] as useful or important is different than personally valuing it. For me, and probably a lot of my peers, understand that it's important and know that we should care about it more and understand why it's so valuable. But at the same time, I skipped all my military history classes. I feel guilty about it because I know I should care but I just don't.... A lot of people know it's important but just don't care enough. Certain individuals, some of my classmates, absolutely love it and can't get enough of it. I would guess the majority of us are not like that but that might just be my immediate peers. But our generation, or society as a whole, everything is immediate. Immediate fitness, immediate fast food. All of us want things and want them right now. We don't want to work for them, we don't want to wait for them. And that's not just with education, that's with everything. So probably it needs to be changed or it would benefit from being changed.

Attitudes towards Army heritage was nuanced. While those who indicated that

they have little interest in it, they did understand its importance. Others had a very

positive attitude towards history and those who did thought it a shame that not everyone

shared their views. For example, Avery responded:

I'm pretty sad. No one was really interested in helping you out [with the study].... I think the military history course that we took was probably the most important course.... Maybe it's just an age thing or maybe I'm coming at it from a different perspective. But that really bummed me out...that more people aren't into it.... And it bothers me that you're going to try to basically start from square one when you don't have to. When you have other people's lives and livelihoods in your hands.

842 "The U.S. Army Chief of Staff's Professional Reading List,"

https://history.army.mil/html/books/105/105-1-1/index.html. 
One of the defining features of the military subculture is the suppression of individual identities and the promotion of identify with the organization, or what Victor Turner explained as the separation stage of the rite of passage. ${ }^{843}$ This is not a value judgement, rather a recognition that the uniqueness of military life requires selfless service and adherence to a regulated set of norms and behaviors, and this proclivity is another means in which participants "othered" themselves. Val recalled that "We're trying to get away from 'this is how I look like and this is how everyone should look like....' We do look at is as one team, one fight. Are you good at what you do? Even in basic training, brother to your left and sister to your right and that's it. We all wear the same uniform."

As already mentioned, heroes provided aiming points for cadets who lamented the possibility that "cancel culture," the practice of withdrawing support for public figures (even historical ones) after the realization they may have said or done something objectionable or offensive in the past in relation to today's societal norms, may challenge the highlighting of institutional heroes or icons. ${ }^{844}$ While this topic was not part of the interview guide, 22 cadets introduced the subject during their interviews. The recurrence of this theme indicated the importance of institutional icons for participants. In those conversations, when asked to imagine an Army without heroes, participants were able to view the lives of the Army's icons in the social context of their time rather than judging them based on modern societal norms. Jamie's attitude toward "cancel culture" was vitriolic:

\footnotetext{
${ }^{843}$ Victor Turner, 94, 103.

844 Dictionary.com, s.v. "cancel culture," accessed January 22, 2020, https://www.dictionary.com/e/popculture/cancel-culture/.
} 
That's something that I absolutely disagree with, the whole cancel culture thing, doxing, the fact that, let alone that these people lived hundreds of years ago, that lived in really different cultural and social standing who...the fact that you can't differentiate some of the things they did and maybe draw inspiration from the things that they did and accomplished in spite of the things that we look down on now, much less than recent people who make mistakes, but often times we see it as a mistake in someone's past. And it gets brought to light, so their entire body of life's work and everything they've done to that point is kind of discounted. I think that is really harmful because if you don't believe in the ability of people to change you don't leave that allowance for making mistakes. Then you are going to create an organization that's on edge and unwilling... it doesn't create a cohesive organization at all.

The concept of "cancel culture" was an emotionally charged, recurring topic for participants who seemed to take the revisionism of institutional icons personally, an understandable reaction when considering their adoption of an organizational identity, a key tenant of Sense-Making Theory. In their interviews, participants repeatedly talked about the phenomenon, probably due to the recently publicized events occurring around the nation, namely the toppling or removing of statues and memorials. Challenges to organizational icons were viewed as tantamount to challenges to individual identity. In a sense, it was seen by these cadets as an outside threat, requiring the protection of their identity and suggests a source of communitas, the feeling of belongingness amongst individuals in a state of liminality. ${ }^{845}$ Three cadets who mentioned "cancel culture" downplayed any perceived threat and attributed negative reactions towards institutional icons to civilian misconceptions about the differentiating features of the Army subculture. As Sam put it, "I think people understand that the military is a weird wedge. I think if people are going to have a negative outlook on the military, they probably already have one. And if they already have a positive one, they are going to retain that even if they hear bad things." Similarly, Sutton stated, "because everything that they [the hero] done that was negative, people can look that up either way. Whether or not the Army says it,

${ }^{845}$ Victor Turner, 111. 
people will know it's a real thing. People who support the military are going to support them regardless of whether they put this information out or not." Yet, when asked if it were possible to imagine an Army without heroes, Ripley succinctly replied, "I can. I don't like it." While some responded defensively and others were not worried about the prospect of losing institutional icons, zero participants indicated that it would be a good thing to "cancel" all the Army's heroes. However, what was important here was the sense participants had towards out-group members - while some downplayed the erasure of Army icons, they understood it as an outside threat to their institution.

As participating cadets in a liminal status went through a transformational process, they placed their senses of self they partly developed with the aid of hero narratives into the broader context of the Army subculture. They did this through the interplay of existing theories (Sense-Making, Self-Efficacy, liminality, and communitas) by developing a shared sense of heritage, internalizing the ideal represented symbolically through institutional icons (as thought of by Durkheim, Campbell, and Jung) and using those as guides, and differentiating themselves from out-group members. Institutional heroes and icons provided a sense of pride or belonging. They may be viewed, as Durkheim argued, as galvanizing forces that create social and task solidarity, or what the Army views as force multipliers. How to reach new members on their level, or what to do with this information, will be discussed in detail. First, the prime subject of this text, the collective memory of General George S. Patton detailed in Part 1, needs to be addressed. 


\section{Collective Memory}

Evidence in the data collected suggested that the collective memory of Patton remains extant, albeit in a different form from what some memory workers intended. A polarizing figure during and after his life, attitudes towards Patton remained mixed, distributed between negative and positive. Yet, only one participant in this study reported a singular (and negative) viewpoint of the icon. If in the past people either loved Patton or hated him, 14 cadets in this sample seemed to love and "hate" him at the same time. Those who responded with some detail about Patton $(n=15)$ had nuanced ideas about him. The most often given negative responses included the ideas that he was impersonal, had pathologies including narcissism, mistreated soldiers, and was frustrating for several cadets who appreciated all his great achievements but were simultaneously dismayed by his gaffes and shortcomings. Positive responses included the fact that Patton was needed by the war effort, and he was an innovative, resilient, and effective leader who achieved his objectives. Even the twelve cadets who could not provide any details at all about Patton recognized his name and understood his importance to the institution. While all of the participants knew of him before, every cadet who did have some knowledge of Patton had a distorted picture of him. Their understanding of the man was shrouded by myth and misconception, indicating that there is little deviation from the origins of the Patton collective memory, at least in terms of this sample. Halbwachs pointed out that conceptions of the past are affected by mental images employed to solve contemporary issues, making collective memory a shared reconstruction of the past based on common conceptions of the present. And as those conceptions evolved over time, being fed from multiple sources, the overarching 
narrative, as explained in Part 1, became revised. The Patton legend was based partly on truth, partly on myth and continues to be so, illustrated in this study. And, as I previously argued, collective memory does not rely on consensus, rather any agreement on narrative is the ideal to which memory workers strove.

For example, Jamie described Patton as "a tank commander" (he was actually a cavalry officer) who "wasn't a very personable guy sometimes. He could be an ass and wanted to do things his way but ultimately he was kind of an innovator in battle. He got the mission done." Ellis heard of Patton from "one of the movies" and Galen responded, "I don't know enough to discuss. I think of tanks but don't go too much further than that. I know he was a great leader. I guess that's what I hear." Ripley watched the movie Patton and remembered from it that Patton

was a rough asshole, effective leader who felt betrayed by the higher brass because he saw himself as super effective, by most accounts he was, and he was being withheld by politics and bureaucracy.... Patton is one of the most frustrating figures. Because you have one of the most effective leaders ever. I mean, the dude, the way he ran his army, he could have easily gone to Berlin. But at the same time, think about today. Someone like General Milley [the current Army Chief of Staff] came down and slapped the shit out of some soldier with PTSD?

For an officer like General Milley to hypothetically strike a soldier today would be, for Ripley, unimaginable, yet the successes Patton had were undeniable. Barry recalled the contestation between Rommel and Patton. "His battle with Patton was never something I would have looked into if it wasn't for that project [the MS II assignment]. I still know it. Controversy. Everyone loves a good controversy."

Even though twelve cadets only had a vague notion of Patton, such as Hayden, who reported, "Just everyone in ROTC mentions him every now and then...[his name is] tossed around a lot," several other cadets made personal connections to the Patton story. Dakota was an enlisted soldier prior to becoming a cadet and worked in the senior executive services. Dakota recalled that "they made quite sure I was aware" of the story 
of Patton's driver during the fatal car crash. For some, the name Patton conjured up

memories from their childhood. Avery talked at length about Patton and recalled:

Yeah, I do want to talk about Patton though. I think the very first interaction I had with Patton was at the Patton Museum when I was a child. Like when I was super ate up with all this Army stuff. My dad took me and my brother to the Patton Museum. And like seeing the tanks and stuff was really cool. And then I didn't think too much about it until there was...a period of time on the History Channel...where they just idolized Rommel and Patton. I remember seeing more of that. So those are probably my youngest impressions and then at some point listening to a podcast getting exposed to his speeches to his men, the one that's full of cursing. I think it may have been a Jocko podcast.... I know he was a controversial figure... and there was some head butting about how important he really was and all that.

Others also noted memories of family members when they thought of Patton. Oakley's mother censored the first scene of Patton because "she saw it ahead of time and saw all the German soldiers mangled up in tank tracks." For Oakley, Patton was "Definitely a controversial figure. Getting fired twice. Slapping some shell-shocked soldiers, but he got the job done, so both controversial and inspirational at the same time." Morgan remembered, "my dad has this bookcase and he's read about every notable Army general. I remember seeing his [Patton's] name up there and all over the freaking bookcase was Patton. I've heard so many things that he did."

While five cadets had little understanding of who Patton was and were therefore ambivalent to the collective memory and one had an exclusively negative view of the icon, twenty-one participants extended a certain amount of leniency to Patton and lauded his achievements. Landry lamented the tendency of current officers in the Army to not assume risk in order to save their careers. "But when you see Patton...yes he made all these mistakes, but what is he known for? He's known for being an awesome leader. He's not known for all these mistakes. Yes, he made them. Be he rose above them and so can you. But in the same breath, like it's still motivation to do better..." Others who took a more negative view were less sympathetic, such as Quincy who was "not a big 
Patton fan...just the personality that bothers me about Patton.... I attribute most of his success to Eisenhower." Even those who responded positively towards the Patton story overall typically cited negative aspects of his behavior, the slapping incidences in particular. Some simply idolized Patton, flaws and all, such as Harper who responded:

Yeah. Blood and Guts. I mean, he's a beast. He wasn't good at listening to orders but he got the job done.... I love Patton. My [family member] served under him. And he talked super highly of him. And he was with Patton personally when they saved the Lipizzaner stallions.... Until the day he died he talked about how much he loved Patton.... He went and saw the movie Patton and it was the greatest thing he'd ever seen. That guy led from the front and he had personal interaction going through field hospitals and everything like that.

Scholars of historical memory are concerned with selectivity, meaning there are certain aspects and narratives of the past that survive as artifacts that illustrate the processes of public and collective memory. What is remembered and what is forgotten, which are equally important to understanding how historical memory works, is only one of the issues of memory studies. As argued previously, we can glean from public memory the intent of persons or groups in the creation of those memory markers, i.e. memorials, documentaries, populist biographies and the like. But the projection and reception problem remains. Just because agenda-driven memory devices projected certain narratives of the past does not necessarily mean intended audiences received and accepted those messages. Confounding the issues are lies, half-truths, or other fabrications, as I demonstrated with the example of conspiracy theories in Chapter V. Whether or not the collective memory of Patton is fraught with lies, inaccuracies, misspeak, etc. is irrelevant because they have the same effect. They obscure the truth rather than illuminate it. And when something, either truth or falsity, is repeated again and again, it compounds that effect. Since memory is always concerned with the present and is a reflection of current attitudes, politics, ideologies, legacies, or developing identities, what is remembered, or the collective memory, becomes increasingly skewed 
over time. And because historical scholarship does not have the same level of influence than that of popular culture references, swaying public and collective memory, for historians, is challenging. After all, collective memory is the subjective conceptualization of the past by a specific group of people that is not reducible to the concept of truth.

While some participants demonstrated a complex view of Patton, the overall picture of Patton amongst participants who did know some details about his story reflected the legend. Understandably so, as many misconceptions that shrouded the truth of this particular individual were repeated ad nauseam by populist biographers, in films and movies, and conspiracy theorists for decades. Objective, scholarly takes on the Patton story are not as accessible, so any misunderstanding of Patton today must be forgiven. For instance, because of Patton's self-aggrandizement and showmanship coupled with the common lack of understanding of the man on a personal level, responses that indicated the attitude that Patton was a narcissist confused confidence and frustration for hubris and arrogance. ${ }^{846}$ Similarly, attributing success to Patton's contemporaries, particularly to Eisenhower or Bradley, indicated that these two individuals' narratives manifested during the battle of post-World War II legacies won the day even though Patton was far more popular during and after the war. At the same time, it is easy to attribute success to higher-ups or the entire organization while attributing failure to an individual, a commonly accepted behavior for "good" leaders and a regular practice of Patton's. By doing so, much of the Third Army success during

\footnotetext{
${ }^{846}$ This was Bradley's critique of Patton projected in his memoir, A Soldier's Story. See Blumenson, Man Behind the Legend; Axelrod, Patton: A Biography; D'Este, Patton: A Genius for War; and Morningstar for a more nuanced interpretation.
} 
World War II became attributed to the unit with little regard for its leadership. The same may be said for negative attitudes towards Patton's personality, a common critique of the two war legacy narrative victors, Bradley in particular, manifested in the film Patton. Failures become the fault of the Army leader. The idea that Patton disregarded the welfare of his soldiers and casually dismissed concerns for their lives in a quest for glory completely discounts all empirical data that points to the contrary - Patton's Third Army arguably captured more territory, killed or captured more German troops, and liberated more towns and cities while sustaining fewer casualties than any other Allied army on the Western Front. ${ }^{847}$

As far as the collective memory of Patton is concerned, the polarizing figure that emerged during World War II appears to be just as polarized today. It seems as though none of the competing narratives won completely and historians' more objective projections never gained full traction at all. Or, conversely, an interpretation that the narratives projected by both Patton protagonists and antagonists won simultaneously is valid, meaning all projections worked as intended, perpetuating the cacophony of viewpoints that defined the convoluted collective memory from its inception. As Halbwachs asserted, people are members of many different groups simultaneously, so the memory of the same fact can be placed within many different frameworks. Yet, when individuals remember within the framework of a group's perspective, the group affirms that memory which then manifests itself within individuals. The idea that people either love Patton or hate him, however, does not hold, at least in this sample. The cadets who took part in this study, for the most part, had a nuanced view of the hero/icon, indicating

\footnotetext{
${ }^{847}$ See Morningstar.
} 
that the institution's collective memory evolved in response to changing interpretations that occurred over time. The Army now seems to project a narrative of Patton that examines both his successes and his flaws. ${ }^{848}$ What was clear in the data was that a collective memory of Patton remains, due in large part, as Halbwachs recognized, to reading, listening, or participation in commemorations or other rites.

\section{A Grounded Theory: The Transformative Hero Model}

Literature regarding heroes in society provides ample explanations of their importance to people and groups, yet there remains a dearth of material regarding how institutions that utilize transformational processes to socialize new members who are in a liminal status may use hero narratives. Transformational processes are those through which new members of an institution become socialized by accepting normative behaviors. In the case of this study, the Army's process transforms civilians into soldiers and officers by gaining acceptance of normative behaviors, such as the adoption and internalization of the Army Values, Warrior Ethos, Code of Conduct, and adherence to the UCMJ and Army Regulations as detailed in Chapter VIII. This study contributes to extant literature by positing a new theory that suggests possible applications for institutional icons or inspirational figures, particularly in the personal development and socialization of new members. Utilizing the concept of social solidarity as a motivating factor and assuming the validity of Sense-Making, Self-Efficacy, and Affective Disposition Theories, along with literature on heroes and archetypes, the theory described below melds all of these concepts and ideas into a model that illustrates how collective memory may have an impact on individuals within the framework of a particular

${ }^{848}$ See Field Manual 100-5 Operations (1993) and Field Manual 6-22 Army Leadership (2006). 
institutional subculture. It is, in a sense, a concept that describes what liminal members seem to be doing already as they cognitively approach and utilize hero narratives while they develop themselves and become socialized to organizational normative behavior.

The theory's name might be considered a triple entendre. First, heroes went through a transformational process themselves as they undertook the heroes' journey. That journey was transformative. Second, heroes, as demonstrated in this study, have potential utility in the transformational process of others, particularly in the personal cognitive development of young adults. The journey through a liminal experience these individuals take may also be transformative. Finally, organizations might use hero narratives to transform members into fully functional, socialized members of a particular subculture. A deliberate transformative process may be taken advantage of to transform the organization.

First, an orientation to the model may be helpful. The Transformative Hero Model (see figure 4) centers on the concept of self and should be read as a concentric circle diagram, read from the inside outwards. The square denotes the organization's subculture as a bounding structure: the entire processes occurs within that framework. The hero's journey is represented as a triangle, a backdrop or substructure that suggests how hero narratives should be told in order to take advantage of the model's potential and also hints at the same type process members in a liminal status are going through themselves. The concentric circles begin with the self which is surrounded consecutively with circles representing personal heroes, extrapersonal heroes, and institutional icons. The double arrows indicate the processes of sense-making, self-efficacy, development of social solidarity/unity of purpose, and socialization as well as the period of 
liminality/communitas. The sense-making arrow illustrates how individuals progressively develop themselves and make sense of their place in the organization through the use of heroes and icons and simultaneously receive feedback about that process from the subcultural framework and the icons and heroes denoted in the concentric circles. The socialization arrow indicates the same type of process in which the individual uses heroes and icons to socialize themselves into the subculture while also receiving feedback. Likewise, the self-efficacy double arrow illustrates how individuals gain self-confidence as they navigate through the period of liminality and the liminality/communitas arrow indicates how feelings of belonging may increase in the process of becoming full members of a subculture. Finally, the social solidarity/unity of purpose arrow demonstrates how individuals gain a sense of group unity and task cohesion as they get closer to full membership all the while receiving feedback from the subcultural framework, institutional icons, and heroes.

Figure 4: The Transformative Hero Model: A Grounded Theory

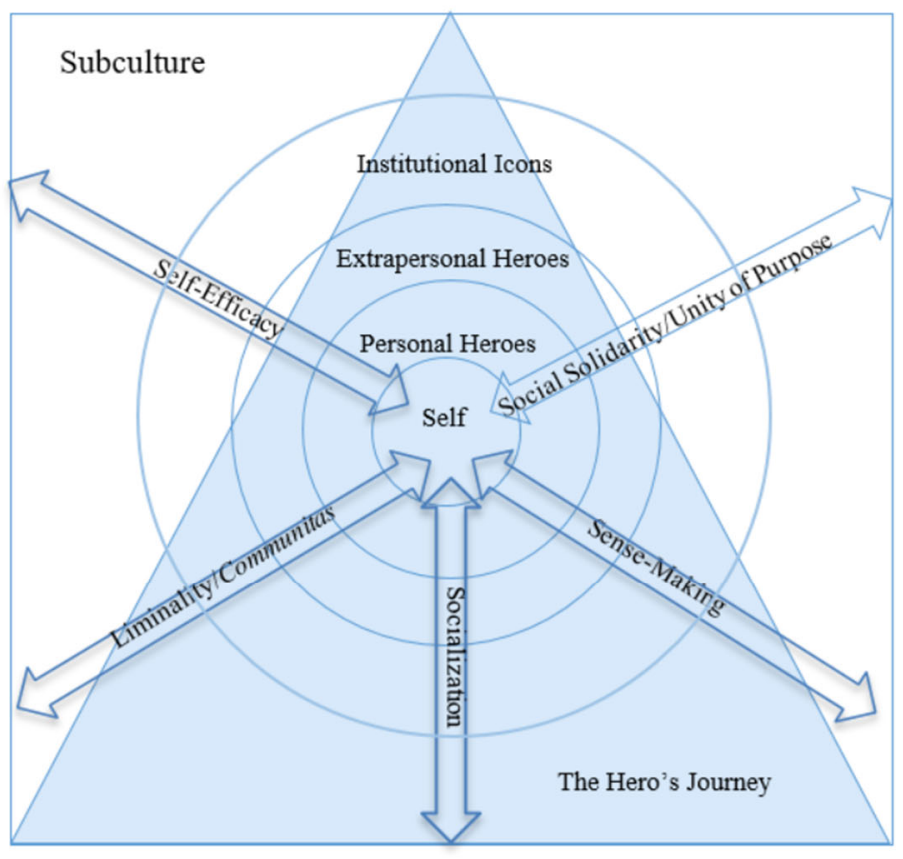


According to this study, young adults in a liminal experience seem to look for inspiration from others, especially personal heroes, to help develop themselves into the persons they want to be for well-reasoned and pragmatic purposes. Again, this points towards the individual need of achieving one's full potential. In the case of this study, that purpose was to become "good" Army leaders. This is not to suggest that individuals copy their heroes' behavior, rather they model themselves after conceptually useful characteristics illustrated by their heroes, a concept mirrored in Self-Efficacy Theory, and by extension, Social Cognitive Theory. They tend to separate the good from the bad and take inspiration from the story while melding those attributes into their own character. Yet, they do not desire a censored hero story: they want to learn about the negative aspects of hero stories in able to heed warnings as they navigate their own journey. Simultaneously, the same cognitive process applies, that of an ongoing retrospective development of plausible images that rationalize what people are doing, as individuals begin to make sense of their place in an institution, as understood through the lens of Sense-Making Theory.

Many personal (and extrapersonal) heroes have close ties to the same organization to which individuals strive to gain membership. As the Transformative Hero Model suggests, individuals in a transformational (liminal stage) process appear to use personal heroes to both help develop themselves into what they want to become, gain the confidence to do so (self-efficacy and the psychological need of esteem), and use those stories to help make sense of how their personal value systems and beliefs nests within an organizational subculture (sense-making and socialization). Because personal heroes were most often reported first, these type of heroes are represented as the first concentric 
circle beyond the self. As individuals model the behaviors of others, beginning at an early age, they transform themselves into autonomous adults and reflect on how well they orient themselves in the world using their personal heroes' positive characteristics as measurement.

Seeking inspiration beyond personal heroes leads individuals to extrapersonal heroes, those inspirational figures to whom they do not have a personal connection but do illustrate many of the same characteristics and attributes they may potentially make their own. In the bounds of the transformational process and the subculture, these figures, like personal heroes, very often have connections to the same organization they are becoming a part of and, while not explicit in the narrative, appear to illustrate qualities the institution values. Conceptualizing what those qualities are and interpreting them in the context of extrapersonal heroes is a process left to the individual, although it is plausible that institutions may have an influence on those choices. While the reasons why individuals (subjectively) choose personal and extrapersonal heroes may differ, they are similar in regards to demonstrated behaviors and the manner in which individuals use these hero narratives are indistinguishable - the same theories apply. This occurs mostly during the early stages of liminality/communitas, also illustrated in the model, before they are fully aware or informed of the institution's icons and the cultural framework, as individuals are more familiar with their personal and extrapersonal heroes. As they explore their place within the organizational substructure (socialization and sensemaking), they also create bonds with each other (communitas), a practice that may be replicated in the form of social solidarity and unity of purpose as they near full membership. It is important to note the stories of personal and extrapersonal heroes seem 
to resonate strongest with individuals - they were chosen by the individual for specific reasons, hence why they encircle the "self" at the center of the model.

As the model illustrates, the processes of individual sense-making, self-efficacy, socialization, and the development of social cohesion and unity of purpose occur simultaneously and work in both directions - the individual processes information comparatively to their personal development and their stage within the period of liminality, and personal and extrapersonal heroes, along with the institution through the use of icons and the subcultural framework, provide feedback to the individual. Institutional icons, or symbols of the ideal, may or may not be the same heroes as personally chosen extrapersonal heroes but are typically identified for them by the institution, as we have seen in the case of Patton. These icons are more than heroes: rather, they are part and parcel of the subcultural heritage, oftentimes individuals who exemplified something heroic (but not always), and illustrate certain points about the subculture itself, perhaps even its collective identity. They have the potential to work much the same way personal and extrapersonal heroes do for individuals.

Durkheim illustrated this point with his treatise on totemic symbols. These stories provide explicit examples of valued characteristics, leaving the individual with less interpretive work in order to find meaning. Halbwachs understood that members of a collective are obliged to view the past through the perspective of the group, particularly when narratives of past members are used. Through an attachment to value systems, past, present, and future members connect. Institutional icons work much the same as personal and extrapersonal heroes in that they illustrate to the individual what personal characteristics and attributes the organization values in its members, signaling back to the 
individual what it takes to become fully socialized into the subculture. This, in turn, informs individuals what needs to be prioritized in the process of personal sense-making. Similarly, institutional icons represent the ideal and serve as aiming points, in adherence with Self-Efficacy Theory, as members in a liminal state develop and acclimate themselves to their new surroundings and form bonds with others sharing that experience. An organization may use storytelling as a mechanism to teach new members about its icons as part of the socializing process. The influence personal heroes have on how individuals relate to extrapersonal heroes and institutional icons is salient. If institutional icons do not fit the same conceptual mold of personal and extrapersonal heroes, individuals in the transformational process may not find much enjoyment or utility in those stories and may find socialization difficult, as posited by Affective Disposition Theory.

These processes occur within a framework of an organizational subculture that provides structure and purpose. Institutional icons, which reside within the overall subcultural framework as part of the institution's heritage, have the potential to demonstrate subcultural values, prosocial behaviors, or behavioral norms. Like Durkheim's work on religions, Halbwachs posited that individuals rely on a framework to recall the past, a past that provides continuity across generations and forms a sense of shared identity. Part of that subcultural framework, along with other prosocial behaviors such as those detailed in Chapter VIII, is an institutional collective memory. And when that collective memory is passed to new members, it becomes part of an organization's heritage. Members undergoing a transformational process that moves them from one mode of being into another do so with a purpose in mind. Choosing particular heroes, 
humanizing narratives and making personal connections to those heroes, modeling and regulating behavior based on a subcultural framework that values certain behaviors and beliefs over others, using heroes as aiming points or symbols of an ideal - the processes of individual sense-making and self-efficacy - do not appear to be mutually exclusive processes from that of making sense of place within the subcultural framework (socialization) or the development of social solidarity and unity of purpose.

The institutional goal of fostering social cohesion and unity of purpose through the adoption of normative behaviors demonstrated by institutional icons has the potential for being met as new members define themselves as unique from out-group individuals (all negative connotations aside) and foster a shared sense of heritage. This also may be a source of communitas as individuals within the liminality stage rally together against perceived threats from out-group members. And, it should be noted, the sense of social solidarity and socialization may be carried on after gaining full membership into the organization. Meanwhile, individuals undergoing the process potentially develop a sense of empowerment (self-efficacy) that increases as they go through the process by gaining inspiration and internalizing lessons from their heroes, either personally chosen or provided by the organization.

The backdrop for the model is Campbell's monomyth of the hero's journey that serves as a substructure. The dual processes of individual sense-making and socialization fit into the schema: those undergoing the transformational process are themselves going through a journey to become members of an organization with its own culture, a hero's journey in a sense, all the while using heroes and icons that fit Jung's archetypical model to aid in the process. As perhaps the most recognizable schema, this substructure allows 
individuals to humanize heroes and connect to their narratives, then apply that knowledge to their personal development and socialization. Because of the monomyth's enduring impact on human consciousness, it is represented in the model as a triangle (shaded to indicate its importance and to aid in recognition), one of the most structurally sound geometric shapes. There is potential for the organization to make these processes (the personal development of new members, social solidarity, socialization, and the fostering of task cohesion) more effective if it tells the stories of its icons in terms of the hero's journey monomyth.

This grounded theory contains echoes of psychologist Urie Bronfenbrenner's Ecological Systems Theory, which posited that human development occurs over time as part of a complex process involving a system of interactions within the individual and between the individual and environmental contexts. In Bronfenbrenner's model, relations between settings and the individual contribute in the personal developmental process. The Ecological Systems Theory also utilized a set of concentric circles, each representing proximal settings to individuals. While the Transformative Hero Model centers on the retrospective individual rather than close proximate interpersonal interactions (the microsystem), the mesosystem setting in Bronfenbrenner's model approximates the extrapersonal hero level of the Transformative Hero Model in that those relationships are somewhat more distant than personal heroes. Likewise, the next setting in the Ecological Systems Theory, the exosystem, is akin to institutional icons and the macrosystem (defined as a set of overarching beliefs, values, and norms) aligns closely with the subcultural framework illustrated in the Transformative Hero Model. ${ }^{849}$

\footnotetext{
${ }^{849}$ Urie Bronfenbrenner, The Ecology of Human Development: Experiments by Nature and Design (Cambridge, MA: Harvard University Press, 1979).
} 
There are some key differentiating features between the two theories. First, the Transformative Hero Model considers the goals of an institution in the process - an organization using this model may use a specific phenomenon to attain desired outcomes. Bronfenbrenner's theory was also more generalizable - the Transformative Hero Model has more parameters, namely that it occurs within the context of an explicit transformational process and unique subculture. While the two theories consider feelings of belonging and an increase of confidence, the Ecological Systems Theory emphasizes the active role of the individual in the developmental process: the Transformative Hero Model goes a step further by also placing an emphasis on the role of the collective, especially with the collective's heritage, in the process of personal development, albeit in a specific context.

\section{Discussion}

\section{Application of the Theory}

In keeping with previous studies that examined how individuals use the past for personal and pragmatic reasons, this study came to similar conclusions as to how individuals approach organizational heritage from a self-centric vantage point. ${ }^{850}$ Understanding how this process occurs may reveal opportunities for institutions, such as the Army, which utilize transformational processes. For example, the Center of Military History $(\mathrm{CMH})$ is an organization within the Department of the Army that has the mission to "accurately collect, preserve, interpret, and express the Army's history and material culture in order to educate and professionally develop our Army, the military profession and the nation more broadly." ${ }^{851}$ As part of the $\mathrm{CMH}$, the Museum

\footnotetext{
${ }^{850}$ See Rosenzweig and Thelen, The Presence of the Past: Popular Uses of History in American Life. 851 "U.S. Army Center of Military History Strategic Plan 2015-2019."
} 
Directorate "preserve[s] a portion of the material culture of the United States" in order to “interpret the Army's history for the purpose of military training, education, and research." As a "side benefit," Army museums "foster morale and esprit de corps, and contribute to informing the American people about the Army's service to the nation." ${ }^{852}$ Historically, the $\mathrm{CMH}$ focused the majority of its efforts on writing histories as a way for military personnel to "learn from the experience of others," to understand the present, and obtain guidance for the future. While "every generation looks to the past for inspiration, wisdom, knowledge, antecedents, and precedents," the CMH unfortunately overlooks the full potential of organizational heroes as conduits of social cohesion. ${ }^{853}$ The CMH has not made a priority of understanding how consumers of the Army's history and heritage connect with the past or what occurs when Army personnel confront hero narratives as they undergo the transformational process.

The "side benefit" of fostering morale and esprit de corps, or social cohesion in sociological terms, may in fact be the most important function the CMH could fulfill from the perspective of its core audiences in regard to institutional hero stories. This study may inform organizations like the CMH how they can acknowledge how their targeted audiences use hero narratives and move away from a "history for its own sake" mentality or as merely a lessons learned tool towards a more purposeful effort that takes advantage of what participants are doing already: developing a sense of self and their place in the institution with the aid of collective memory and gaining inspiration through iconic symbols, heroes, and hero narratives. By retooling a narrative centered on this

\footnotetext{
${ }^{852}$ Army Regulation 870-20 Army Museums, Historical Artifacts, and Art. (Headquarters Department of the Army; Washington, D.C.: 11 January 1999), 13.

${ }^{853} \mathrm{Jr}$. and Robert W. Coakley John E. Jessup, A Guide to the Study and Use of Military History (Washington, D.C.: U.S. Government Printing Office, 1982), 14-15, 17.
} 
idea, the Army history program may remain relevant in the $21^{\text {st }}$ century. As this study suggests, focusing on the production of history books may not take full advantage of the information consumption habits of younger aspiring members of the institution. The Army may do well to shift some of its focus to different mediums that intended end-users more often utilize. The CMH's Museum Directorate may find greater potential to inspire audiences by reframing the Army's heritage seen in museum exhibitions and educational programs in terms of the hero's journey monomyth. For one, the General George Patton Museum has the potential to do just that by reimagining its exhibits and programs for ROTC cadets, but other museums may also take advantage of the model. Every branch and unit has their heroes and utilize transformational processes to socialize new members.

Other organizations might benefit from the model as well. First are the obvious ones. Every branch in the Department of Defense has heroes and history programs, including museums, and also purposefully create liminal experiences for the transformation of civilians into airmen, sailors, and marines. Many religious organizations are also dedicated to socializing new members and creating social cohesion. Some organizations are not so obvious. For instance, groups that help people recover from addictions may find the stories of those who successfully recovered helpful for others to gain the self-confidence to do so, modify their behaviors, develop communitas with others in the program, and develop a unity of purpose. At risk youth programs and boarding schools may do the same. Organizations with unique subcultures such as fraternities, sororities, or other social groups and societies may likewise use their "heroes" to create social cohesion and help members make sense of their place in the 
organization. Sports teams might also take advantage of the model - the stories of iconic figures like Roberto Clemente, Alex Morgan, Jackie Robinson, Simone Biles, Ted Williams, and Jessie Owens have the potential to be a source of inspiration for new members of their respective teams. It must be stressed, however, that organizations wanting to utilize the model may need to customize certain aspects to fit the specifics of their organization, including goals.

To take advantage of the model, parameters that require several assumptions must be established. First, the model applies to institutions that utilize transformational processes. Anxieties stemming from negative connotations attached to the concept of socialization, the process of learning to behave in a way that is acceptable to society (or that of a subculture), must be set aside: for organizations like the Army, socialization is not a bad thing, rather it is an asset, perhaps even a necessity. Those institutions which do not have a negative view toward socialization, according to this model, must also have icons and symbols, especially past members, with a sufficient collective memory that broadly represent an ideal. Next, the model uses social cohesion and unity of purpose as goals so any deviation from those stated goals may affect outcomes. Understanding the cognitive development of individuals in a transformational process as they contend with hero narratives is only part of the equation - how those narratives come to the attention of members is also paramount.

There is plenty of literature that suggests humans are attracted to the hero's journey narrative. However, if the early stages of the tale are omitted and a projection of the story jumps to the conclusion, the opportunity to allow individuals to gain inspiration from that narrative may be lost. It appears as though it is not enough to just say that a 
person was or is a hero. Explaining why is vital. That story may best be told in a framework that people understand - that of the hero's journey. Many organizations have heroes and icons and it seems individuals do as well. To use stories to build pride in an institution and mold new members to adopt subcultural belief systems and prosocial behavior, the hero's journey schema may be a useful tool.

There is strong evidence that people become attracted to the hero journey monomyth at a very early age. Take, for instance, the story of Pinocchio, one of the most re-imagined characters in children's literature, a story with a plot that is easily recognizable in many others. It was an archetypal tale, as perhaps Jung might argue. Gepetto, Pinocchio's "father" created a wooden puppet and wished upon a star that he would be a real boy. A fairy appeared and granted the wish. However, Pinocchio learned that he must prove himself worthy in order to make his father's wish come true. With the help of Jiminy Cricket (a portrayal of Pinocchio's conscious), Pinocchio overcame challenges of temptation from a sly fox, a cat, and a greedy puppeteer. Although he fell short along the way, such as a trip to Pleasure Island where he drank, smoked, and was nearly turned into a jackass, Pinocchio overcame his weakness. His final challenge came when he discovered his father was swallowed by a whale and Pinocchio must find and save him (a descent into and return from the Underworld motif). ${ }^{854}$ While rescuing his father, Pinocchio died but the fairy deemed that he proved his worth and was brought back to life as a real boy. It is a transformational hero story in a metaphorical sense, and a story that those who are undergoing a transformational

\footnotetext{
${ }^{854}$ As an illustration of how this motif is represented cross culturally and over time, the decent into the "Underworld" story is evident in ancient Egyptian mythology in the story of Osiris.
} 
process themselves might relate to. The main character of the story need not be fictional, but the plot should be recognizable.

As already demonstrated, there is value in the use of hero stories to which participants easily relate. Aside from using icons as symbols to represent abstract ideas, using hero narratives of contemporary figures, or stories of iconic individuals when they were operating near the same level as the targeted audience, seems to be a potentially effective strategy. Recounting the accomplishments of high-ranking individuals of the past may not open windows of opportunity for young members of an organization to create personal connections - high ranking individuals are probably so far removed that members in a liminal status cannot imagine themselves in that position.

There also appears a need for better storytellers who can pass on an organization's heritage in engaging ways. If it is true that the attention span of young adults is lessening, then capturing their imagination early and often is crucial. However, it must not be done so in a way that turns a narrative into pure hyperbole. Quincy, one of the cadet volunteers in the study, noted that stories

have been told since 10,000 B.C., but when it comes down to that I'd warn against losing the facts in the way you tell them. So making something entertaining and also educational is extremely difficult. If you went too much to the entertaining route where you just have these great storytellers that give you not just digits and numbers and stuff that I think is important, then you could lose some of the accuracy and over time that would lead to a problem. But yeah, I think better storytellers would help.

Sacrificing accuracy was clearly as much a concern for respondents as was the inspirational value of hero narratives. Most interviewees indicated a desire to know the truth while interacting with inspirational stories. Furthermore, while using hero narratives, cadets understood the social and political context within which heroes 
operated. Judging heroes of the past through the lens of current norms appeared to be a way to diminish trust in the institution.

The delivery mechanism matters as well. Perhaps one of the reasons why not all cadets were knowledgeable about Patton, for example, was that most early mediums about the icon were in print. While half the participants in this study indicated they do enjoy reading, the other half do not like to read, and alienating half a target audience due to the utilization of unused mediums potentially diminishes effectiveness. As Kris put it, "We can barely read. The generation after mine, I don't know how they are going to receive it. Or learn anything.... Our attention span is getting shorter and shorter.” This is not a value judgment, nor would it be prudent, in my estimation, to attempt a course correction within an institution's transformational processes with the aim of fostering a widespread love of reading. There may be no getting around that phenomenon. Leveraging emergent technologies that younger audiences already use has the potential to produce repeat users well after the liminal phase of their membership in an organization. Back to the Patton example, the movie Patton and documentaries may be viewed as dated by this demographic. And they may be too lengthy. Perhaps telling smaller, more digestible excerpts from a hero narrative might be more compelling and inviting.

Humanizing hero stories in order to open avenues for personal connections and sense-making is also a potentially effective strategy. In regards to the Patton collective memory, as an example, telling the story in a more relatable way by means of using examples of his experience as a young officer, relating his successes as well as his failures, and illustrating how he demonstrated the normative leadership principles adopted by the Army may be a more efficacious use of the collective memory. In the 
search for truth, while telling a good hero's journey story, dispelling myths and misconceptions may be a means to gain the attention of those in a transformational process. After one cadet repeated the "Blood and Guts, more like our blood, his guts" idea, I told the story of Patton's popularity amongst his troops, detailed in Chapter III. The response was indicative of how this approach may be useful: "I mean, I just got little chills thinking about that. And I'm thinking about how I can create that within whatever group that I take over. I would focus on that."

\section{Contribution to Literature and Implications for Future Research}

Academically, as an interdisciplinary study, the transformative hero model is germane on several fronts and has potential implications for a range of academic disciplines. It is a modest contribution to organizational studies through the examination of how institutions may use collective memories (in the forms of history, heritage, and hero/icon narratives) to create social solidarity in transformational processes. It also has potential importance for the fields and subfields of cultural, military, and public history; museum studies; memory studies; organizational sociology; and organizational behavior. The grounded theory addresses the common consumption and use of history, heritage, heroes, and icons; the use of heroes and icons in institutional transformational processes; and the questions of projection versus reception in collective memory. Applying and measuring the effectiveness of the model, or a derivative of it, or adding other theoretical frameworks to the model has the potential for institutions to more fully socialize new members and may open up future areas for study. Furthermore, this may be one of the first interdisciplinary approaches to make an honest attempt to address the projection/reception problem inherent in history of memory studies. On a practical level 
and micro level, the model may inform Army and CMH policy makers of ways to adjust the focus of their history and heritage programs to take advantage of the phenomenon of how individuals approach and use hero narratives.

\section{$\underline{\text { Limitations }}$}

As with any study there are limitations to its findings. First, although the sample was small, the qualitative grounded theory method utilized in this interdisciplinary study is well established and theoretical saturation was attained. Secondly, although I reason that the sample was generally similar demographically to the entire Army officer and ROTC cadet populations, the study was conducted at a single university. Additionally, while fundamentally similar, the ROTC program is just one of several types of transformational processes used by the Army. Others include the U.S. Military Academy, Officer Candidate School, Warrant Officer Candidate School, and Basic Military Training, to name a few. Finally, some of the cadet participants have been contracted, meaning they were on scholarship, and did have an incentive (but not an obligation) to remain in the program. Although they have not gained full membership in the institution, there was the possibility this affected their willingness to respond freely to questions.

Although steps were taken to minimize biases, there can be no guarantee that those biases did not come into play. For example, since the study's recruitment sought opinions about heroes, it is possible that cadets who volunteered were those who found the topic most salient and had the most favorable views on heroes. Timing may also have contributed to the limitations of this study. Collecting data during a global pandemic might have altered the sample size to a certain degree (sample selection bias): individuals 
may have been disinclined to volunteer for an in-person interview. Although most interviews were conducted prior to the nationwide lockdowns resulting from the COVID19 outbreak in the United States, the final interview took place telephonically. It was quite possible that more interviews could have been conducted; however, it is unknowable if or how any additional data would have changed the outcome. However, by that point, saturation in the data was achieved, and all interviews conducted save for one over the telephone.

After the lockdowns occurred, Americans began to think more critically about authority and how far governments should or could go in regulating personal behaviors and the operation of private businesses. Anecdotally, as certain jobs became classified as "essential," many Americans seemed to reconsider the idea of a hero - popular parlance indicated that doctors, nurses, public health officials, delivery persons, grocers, child care workers and others who placed themselves in precarious situations on behalf of others became heroes. Many of these people faced down an emergent threat, often at great personal risk. However, I speculate that the same model could apply: those individuals demonstrated the same characteristics that participants reported as being desirable in their heroes; they demonstrated selfless service, sacrifice, courage, etc. Perhaps the rubric of "hero" will expand, opening up further research opportunities.

Other societal events prior to or concurrent with data collection may have affected responses, particularly the aforementioned removal or destruction of statues and memorials that some Americans deemed offensive or insensitive. Some of those concrete forms of public memory were dedicated to Army icons, such as the case with George Washington. Publicity of those events may have caused the concept of "cancel culture" 
to come up in the interviews and may have prompted those who view these acts with trepidation to more readily volunteer for the study. This certainly shaped the findings of the study, though it does not invalidate these concerns. "Canceling" institutional icons appeared to be a source of disquietude for many respondents well before the proliferation of such acts that occurred in mid-2020. Data collection was completed prior to April 2020.

It was extremely difficult, if not impossible, to mask the fact that I have a very strong tie to the Army. Military members can easily and quickly identify other members of the subculture. Although this may be cause for concern, in grounded theory methodology this is not a negative. Theoretical sensitivity indicates "an awareness of the subtleties of meaning of data," allowing the researcher to "come to the research situation with varying degrees of sensitivity." It refers to the attribute of having insight, the ability to give meaning to data, the capacity to understand, and capacity to separate the pertinent from that which isn't." ${ }^{955}$ The benefits of Verstehen should not be underestimated.

Understanding the key issues of transformation in the Army, the literature on the role and use of history in people's everyday lives, and the salient sociological theories and concepts used in the framework was paramount to gain insight while addressing research questions. And it is important to note that I have been through a similar transformational process as those whom I studied.

Finally, as with most qualitative studies, there is the question of generalizability. The Transformative Hero Model is not an attempt to create a broad prescription for all types of organizations. It may be viewed as an exploratory theory based on inductive

${ }^{855}$ Strauss, 41-42; Barney G. Glaser, Theoretical Sensitivity: Advances in the Methodology of Grounded Theory (Mill Valley, Calif.: Sociology Press, 1978). 
processes. In regards to generalizability, the purpose of a grounded theory is to specify the conditions that give rise to specific sets of action and interaction pertaining to a phenomenon and the resulting consequences. Generalization regards process, not about a group or population, and pertains only to those specific situations outlined in a grounded theory. The more systematic and widespread the sampling, the greater the generalizability. Thus, there is potential for some grounded theoretical insights to be generalizable to similar, or even some dissimilar, ROTC programs, assuming that the analytic sample is consistent with ROTC characteristics nationwide. Lastly, there is potential for future studies to test specific aspects of the grounded theory in a deductive manner. 


\section{CONCLUSION}

George S. Patton, Jr. was born in California on November 11, 1885. He had loving parents and a doting aunt who lived with the family. However, Aunt Nannie believed Patton had some sort of cognitive impairment and lobbied his father to keep him out of school until the age of 12. It was not until he entered Steven Clark's School for Boys that Patton began to learn to read. Before that, his father read to him religiously, and in the process Patton developed an ability to memorize long verse, a skill he was able to recall in adulthood. Yet, the delay in education came to bear when Patton applied for university. His first choice was the U.S. Military Academy, but he was not admitted. So Patton attended the Virginia Military Institute for a year, then reapplied to West Point. After being accepted on his second attempt, Patton started his college career over, repeating his first year at West Point - and subsequently failed. One of the greatest combat commanders the U.S. Army ever knew started his military career as a failure.

After six years as an undergraduate, three as a first-year student, Patton finally graduated in the middle of his class in 1909 and commissioned as a cavalry officer. He served in the Punitive Expedition before going "over there" to France to fight during World War I. The early stages of his career were not without adversity. His meteoric rise during the Great War in which he earned the rank of Colonel was matched only by his sudden reversion to Captain after the war's end. He was wounded on the first day of the Battle of the Meuse-Argonne, nearly dying in a shell hole alone after trying to rally some cowering infantrymen in a failed bayonet charge. After returning home, he 
watched as his newly beloved Tank Corps was utterly dismantled during post-war disarmament. In protest, or perhaps as a way to salvage his career, he returned to the horse cavalry, only to watch that branch be undone during the Army's mechanization efforts. The interwar years were not kind to Patton. Ever the klutz, several freak accidents nearly ended his career. For one, upon returning to the mainland after a stint in Hawaii, a horse kicked Patton and he developed an embolism. His doctor prophetically told him that if he ever got another embolism, it would kill him.

However, Patton never stopped striving to be the consummate professional soldier that he ultimately became. Everything about the man was geared to that purpose. There was nothing special about him that set him apart from his peers other than an insatiable desire to succeed and the self-discipline needed to do so. He thought, wrote, and argued his way to becoming the Army's household intellectual of his time. As the Army prepared for World War II, Patton swam against the cultural currents of the Army, which nearly cost him a chance to lead troops in the conflict. The infantry's grip on doctrine was tight enough that Patton had to create some enemies in order to demonstrate his methods worked. Fortunately, Marshall wrote Patton's name in his famous little black book that listed officers with promise who could be of use in the next war. But Patton never got the full credit he was due for his instrumental role in training troops and developing units.

Patton's service during World War II, then, was really a microcosm of the ups and downs he faced his entire career. True, he was the general who salvaged the II Corps after its disastrous defeat at Kasserine Pass, bested Axis forces on Sicily (and the British in the race to Messina), led the breakout from the Normandy hedgerows, rescued the 
entire front during the Battle of the Bulge, saved the Lipizzaner stallions from Soviet dinner plates, and peed in the Rhine River while crossing it. But he was also the general who was fired twice (and nearly thrice after the Knutsford gaffe), once after slapping two soldiers and then again after disobeying orders to denazify Bavaria.

Patton was a flamboyant, controversial individual who crafted a recognizable personal brand. News outlets used him as a means to garner public support for the war effort and to lift optimism. While alive, Patton had a following of many people who viewed him as a hero and after his death a collective memory developed about him that spawned from a legend. Under the guise of altruism or nostalgia, certain stakeholders in that collective memory created multiple forms of public memory for various motives: authors sold books, commemorations and memorials drew crowds, politicians gained support and forwarded agendas, retired generals garnered recognition, conspiracy theorists sowed distrust, Patton reinforced American patriotism, corporations sold games, magazines, and toys, and non-profit organizations gathered donations. The narrative projections used by these public memory actors who took advantage of the collective memory fit the needs of their times and reception of those narratives are evident in the Army today. And it is the Army that may have a unique opportunity to use the collective memory of Patton to help socialize new members in its transformational process by telling his story in terms of the hero's journey.

In terms of the hero's journey, Patton's passion for soldiering was both a superpower and a fatal flaw. Although he did not come from meager beginnings, per se, he did face challenges as a child and young man. His entire life was an adventure of sorts. It was marked by many adversities along the way, all of which he overcame. He 
was not particularly more exceptional than his peers other than his innate inner drive, determination, self-confidence, and dedication to his chosen profession. Even so, he became a hero to many. But the hero's journey is supposed to end with the hero's return to share what was learned on the adventure. Patton intended to do just that. He was coming home to retire and, to the fear of Eisenhower, tell America what he learned during the war. But instead, he died in Germany, the hero's journey unfulfilled.

Or perhaps it wasn't. Patton did tell us what he learned on his grand adventure. One just has to know the story. As demonstrated, Patton, through his own volition and with the help of many others, became an international hero. His use of personal branding and flamboyance allowed wartime journalists to bring hope to Americans. Populist biographers and historians fed the legend to generations. People watched the narrative on screens, both big and small, and played games, imagining themselves to be "Old Blood and Guts." That narrative became so pervasive that many groups felt the urge to memorialize and commemorate it in various ways and in many places. For the Army, Patton played a unique role as a legend. His ideas extended well beyond his immediate social sphere, influencing doctrinal development for decades. And the ideal that he represents - the dashing, audacious, charismatic, thoughtful, and effective battlefield commander - also influenced individuals in the Army for generations.

Part 1 of this study explained in detail the creation of a legend that turned into a collective memory, a memory manifested in public settings and within the consciousness of a public and a certain collective. Part 2 demonstrated the collective memory still exists to some degree and suggests how it may be of use. The result is the creation of a new grounded theory, the Transformative Hero Model, which may have implications for 
organizations other than the Army. If Campbell's hero monomyth, ADT, and Durkheim's thoughts on totemism and solidarity hold true, applying them to institutional icons may serve as a means for organizations to socialize members in a liminal status. According to the model, this allows for the dual processes of self-efficacy and sensemaking as members develop competencies and confidence and understand themselves and their place in an organization. And from the perspective of the organization, the fostering of social cohesion and unity of purpose has the potential to increase effectiveness.

For the Army, thinking of Patton as an archetype, role model, icon, or symbol may have a positive effect on the personal and professional development of future soldiers and officers, and has the potential to allow the collective to foster a sense of social solidarity all while promoting the ideal that Patton represents. His story is filled with controversy and intrigue, and perceptions of him are marked by nuance and ambivalence. Opinions about him in the past were dichotomous. But these facts may draw people to his story. Understanding the nature of public memory and its concerns with the present, described through this one example, may also serve as a testament to both the pitfalls and opportunities of using agenda-driven narratives of the past. Nevertheless, Patton's presence is ubiquitous. Retelling his story as a tragic hero's journey may in fact be the key to unlocking all of that potential. With the ever-present and looming foreign threats our nation faces, the lessons he left for the Army, both good and bad, may be of service yet again. But if he is forgotten, those lessons may have to be relearned, and on the battlefield that can be a high price to pay. Patton's transformation from an illiterate teenager to the greatest American general may give future leaders the 
inspiration and confidence to transform into the leaders they hope to become, thereby transforming the Army into even more of an effective fighting force. Understanding Patton's shortcomings and how he overcame them may give these same individuals the ability to forgive themselves and learn from their failures.

The Army, and perhaps our society, may still have a use for heroes. 


\section{REFERENCES}

A Note on Sources: Due to the nature of the study, some secondary sources, particularly biographies, films, documentaries, and websites, are also considered primary sources. For these, while they do provide contextual insights, they are also evidence of the collective memory of Patton. While tracing the evolution of the Patton legend, legacy, and public and collective memory, many sources are inseparable. However, they are aggregated below by type (primary and secondary) and category (i.e. manuscripts, government documents, periodicals, websites, etc.) based on the most common use within the text.

\section{$\underline{\text { PRIMARY SOURCES }}$}

\section{$\underline{\text { Manuscript Collections }}$}

Artifact File CCN 455980. The General George Patton Museum Archives. Artifact File CCN 455981. The General George Patton Museum Archives. Artifact File CCN 457025. The General George Patton Museum Archives. Artifact File CCN 462149. The General George Patton Museum Archives. Corps, U.S. Army Signal. Patton Day Remembrance Events, Ettlebruck, Luxembourg. Photographs. In The General George Patton Museum Archives.

-. Patton Monuments: Image number P11-63. Photograph. In The General George Patton Museum Archives.

"G-1 Section 12th Army Group: Report on Operations (Final After Action Report) Volume 2." National Archives and Records Administration II.

General George S. Patton, Jr. "Letter of Instruction No. 1." In Military Essays and Articles, 61-65: The General George Patton Museum, 1944.

_. "Letter of Instruction No. 2." In Military Essays and Articles, 66-75: The General George Patton Museum, 1944.

_. "Patton's Best Quotes." In Military Essays and Articles, 250: The General George Patton Museum.

"General George S. Patton Jr. Memorial Center, San Gabriel, California." In The General George Patton Museum Archives, c1968. 
"General George S. Patton's Medals and Citations." Edited by First National Bank of Boston:, 1947. In The General George Patton Museum Archives.

George S. Patton, Jr. "War As She Is." In Military Essays and Articles, 366-92: The General George Patton Museum, 1919.

"Good Wishes for Patton." Unknown, December 12, 1945. In The General George Patton Museum Archives.

"Luxembourg Commemorative Stamp Folder." In The General George Patton Museum Archives, 1947.

Maddox, Brigadier General H.G. "In Memoriam - General George S. Patton Jr." US Army Eastern Military Disctrict December 22, 1945. General George Patton Museum.

McKaney, Captain WIlliam A. "Funeral Escort Order." Luxembourg City December 23, 1945. The General George Patton Museum.

"Memorandum of the Joint Chiefs of Staff No. 1067 (revised)." In George S. Patton Papers: Library of Congress, May 10, 1945.

"MSL 201 Leadership and Decision Making Lesson 06: Adaptive Leaders in History ROTC Writing Program Homework Assignment: Written Essay and Briefing." edited by Army ROTC, March 31, 2018. The General George Patton Museum.

Patton, George S. "Brief Notes on the Tactical Employment of Tanks." The General George Patton Museum.

. "Further Notes on the Use of Tanks in Various Operations Including Open Warfare." The General George Patton Museum.

_. "Light Tanks." The General George Patton Museum, December 12, 1917. . "Light Tanks in Exploitation." The General George Patton Museum.

—. "Patton Diary." In George S. Patton Papers: Library of Congress, May 10, 1945. . "Report to The Adjutant General, U.S. Army." In George S. Patton Papers: Library of Congress, September 19, 1912.

. "Saber Exercise." edited by War Department. Washington, DC: Government Printing Office, In George S. Patton Papers: Library of Congress, 1914.

_. "Some Notes on the Effect of Weapons and Means of Communication." 1934. The General George Patton Museum.

_. "Subject: Light Tanks." In George S. Patton, Jr. Papers: Library of Congress, December 12, 1917.

"Patton Hall Dedication." In The General George Patton Museum Archives.

"Patton Plaque." In The General George Patton Museum Archives. Photograph.

"The Stained Glass Windows of the Church of Our Savior." In The General George Patton Museum Archives.

\section{Government Documents}

Army Regulation 635-200 Active Duty Enlisted Administrative Separations. Washington, D.C.: Department of the Army, 2016.

Army Regulation 870-20 Army Museums, Historical Artifacts, and Art. Washington, D.C.: Department of the Army, 1999.

Exec. Order, "Executive Order on Building and Rebuilding Monuments to American Heroes, July 3, 2020." 
Field Manual 3-25 Counterinsurgency. Washington, D.C.: Department of the Army, 2007.

Field Manual 6-22: Army Leadership (Competent, Confident, and Agile). Department of the Army, OCT 2006.

Field Manual 100-5 Operations. Washington, D.C.: War Department, 1941.

Field Manual 100-5 Operations. Washington, D.C.: Department of the Army, 1986.

Field Manual 100-5 Operations. Washington, D.C.: Department of the Army, 1993.

Field Manual 100-5 Operations of the Army Forces in the Field. Washington, D.C.: Department of the Army, 1968.

Field Service Regulations. Washington, D.C.: War Department, 1923.

"General Orders No. 121." Washington, D.C.: War Department, December 22, 1945.

"House Joint Resolution 72." edited by U.S. House of Representatives. Washington, D.C. , 1951.

"House Resolution 174." edited by U.S. House of Representatives. Washington, D.C. , 1951.

Official Congressional Record. edited by U.S. Congress, May 22, 1963.

School Year 2019 Final Military Science 1-4 Survey Results by Brigades and Programs.

"U.S. Army Center of Military History Strategic Plan 2015-2019."

\section{$\underline{\text { Personal Communications }}$}

Christmas Card, C.J. Hammond to Patton. In The George S. Patton Papers: Library of Congress, undated.

Christmas Card, Col D.B. Sanger to Patton. In The George S. Patton Papers: Library of Congress, undated.

Christmas Card, Paul F. Ferreira to Patton. In The George S. Patton Papers: Library of Congress, 1944.

Christmas Card, Roy G. Mill and Clyde E. Rhymer to Patton. In The George S. Patton Papers: Library of Congress, December 1945.

Lemitzer, L. L. "Exerpt of a Letter from Brig. Gen. L. L. Lemnitzer." In The George S. Patton Papers: Library of Congress, May 21, 1944.

Letter, Alfred Crease to Patton. In The George S. Patton Papers: Library of Congress, January 22, 1945.

Letter, Alfred-Carl Gaedertz to Patton. In The George S. Patton Papers. Wiesbaden, Germany: Library of Congress, December 1945.

Letter and Newspaper Clippings, Mrs. Margeurite Therels to Patton. In The George S. Patton Papers: Library of Congress, November 30, 1945.

Letter, Andree Blacfriar to Patton. In The George S. Patton Papers: Library of Congress, April 1, 1945.

Letter, Bessie Lee Porter to Patton. In The George S. Patton Papers: Library of Congress, December 16, 1945.

Letter, Betty Drake to Patton. In The George S. Patton Papers: Library of Congress, October 6, 1943.

Letter, Billy Richardson to Patton. In The George S. Patton Papers: Library of Congress, July 15, 1943. 
Letter, Boardman F. Lockwood to Martin Blumenson. In The General George Patton Museum Archives, December 31, 1985.

Letter, Capital View Methodist Church Sunday School Class to Patton. In The George S. Patton Papers: Library of Congress, March 21, 1943.

Letter, Captain Paul McConihe to Patton. In The George S. Patton Papers: Library of Congress, May 9, 1943.

Letter, Carl L. Meskins to Milton F. Perry. In The General George Patton Museum Archives, June 18, 1954.

Letter, Charles Chomette to Patton. In The George S. Patton Papers: Library of Congress, August 13, 1944.

Letter, Claire Brown to Patton. In The George S. Patton Papers: Library of Congress, November 11, 1944.

Letter, Clifford Mayfield to Patton. In The George S. Patton Papers: Library of Congress, undated.

Letter, D.V. Irvin to Patton. In The George S. Patton Papers: Library of Congress, July $14,1943$.

Letter, Dwight D. Eisenhower to MG J. H. Collier. In The General George Patton Museum Archives, November 9, 1953.

Letter, E. Garland Brown to Patton. In The George S. Patton Papers: Library of Congress, April 27, 1945.

Letter, E. Garland Brown to Senator Carl Hayden. In The George S. Patton Papers: Library of Congress, August 10, 1944.

Letter, E. Garland Brown to Senator Robert R. Reynolds. In The George S. Patton Papers: Library of Congress, May 8, 1944.

Letter, E.F. Ginoulhiac to Patton. In The George S. Patton Papers: Library of Congress, August 27, 1943.

Letter, Elias Van Slyke to Patton. In The George S. Patton Papers: Library of Congress, undated.

Letter, Ernie Mrazz to Milton F. Perry. In The General George Patton Museum Archives, September 23, 1954.

Letter, Everett L. Crawford to General Patton. In The George S. Patton, Jr. Papers: Library of Congress, November 13, 1944.

Letter, Francois de Vaux, Mayor of Langres, France. In The General George Patton Museum Archives, September 6, 1972.

Letter, Fred Jackson to Patton. In The George S. Patton Papers: Library of Congress, September 6, 1944.

Letter, General Koenig to Patton. In The George S. Patton Papers: Library of Congress, December 1945.

Letter, George S. Patton to Walter Dillingham. In The George S. Patton Papers: Library of Congress, March 4, 1944.

Letter, Grace Maud Mason to Patton. In The George S. Patton Papers: Library of Congress, August 19, 1944.

Letter, Grahane A. Patton to General George S. Patton. In The George S. Patton Papers: Library of Congress, August 15, 1943.

Letter, H. M. Hutchinson to Patton. In The George S. Patton Papers: Library of Congress, March 31, 1943. 
Letter, Harriet Nelson to Patton. In The George S. Patton Papers: Library of Congress, December 1, 1944.

Letter, Ira Jackson to Patton. In The George S. Patton Papers: Library of Congress, July 22, 1943.

Letter, J.C. Savage to Patton. In The George S. Patton Papers: Library of Congress, August 16, 1944.

Letter, J.E. Powers to Patton. In The George S. Patton Papers: Library of Congress, March 15, 1943.

Letter, Jack Brown to Patton. In The George S. Patton Papers: Library of Congress, January 9, 1945.

Letter, James A. Bowman to Patton. In The George S. Patton Papers: Library of Congress, August 20, 1943.

Letter, James C. Watterson to Milton F. Perry. In The General George Patton Museum Archives, June 19, 1954.

Letter, Jean Robert to Mrs. George Patton. In The General George Patton Museum Archives, May 4, 1951.

Letter, John H. Mulkeen to Patton. In The George S. Patton Papers: Library of Congress, May 26, 1944.

Letter, Larry Kip Sleeth to Patton. In The George S. Patton Papers: Library of Congress, December 1945.

Letter, Leo Stalnaker to Patton. In The George S. Patton Papers: Library of Congress, December 6, 1944.

Letter, Littlejohn to Major General Harold W. Blakely. In The General George Patton Museum Archives, Jan 2, 1947.

Letter, Louis H. French to Milton F. Perry. In The General George Patton Museum Archives, August 14, 1954.

Letter, Lucille Fincher to Patton. In The George S. Patton Papers: Library of Congress, February 26, 1944.

Letter, Major General E. N. Harmon to Lieutenant Colonel George S. Patton. In The General George Patton Museum Archives, November 3, 1964.

Letter, Major General Ernest N. Harmon (Retired) to Milton F. Perry. In The General George Patton Museum Archives, April 14, 1954.

Letter, Mary Eva Honn to Patton. In The George S. Patton Papers: Library of Congress, April 17, 1945.

Letter, Mary June Krieger to Patton. I n The George S. Patton Papers: Library of Congress, May 25, 1944.

Letter, Mary Pope to Patton. In The George S. Patton Papers: Library of Congress, August 1944.

Letter, Master Sergeant John L. Sims to Mr. Milton F. Perry. In Historical Property Jacket CCN 455980, The General George Patton Museum Archives, October 26, 1954.

Letter, Mayor of Epernay to Patton. In The George S. Patton Papers: Library of Congress, December 20, 1945.

Letter, Mayor of Rennes to Patton. In The George S. Patton Papers: Library of Congress, December 20, 1945. 
Letter, Milton F. Perry to Major General James L. Collins (Retired). In The General George Patton Museum Archives, March 23, 1955.

Letter, Miss Annie Wheeler to Patton. In The George S. Patton Papers: Library of Congress, December 12, 1945.

Letter, Mr. and Mrs. Donald Myers to Patton. In The George S. Patton Papers: Library of Congress, December 7, 1944.

Letter, Mr. and Mrs. Lee Fry to Patton. In The George S. Patton Papers: Library of Congress, December 7, 1943.

Letter, Mrs. Charles H. Thomas to Patton. In The George S. Patton Papers: Library of Congress, April 7, 1944.

Letter, Mrs. Elizabeth Maguire. In The George S. Patton Papers: Library of Congress, March 10, 1943.

Letter, Mrs. Frank J. Unger to Patton. In The George S. Patton Papers: Library of Congress, December 29, 1943.

Letter, Mrs. Fraser Henry to Patton. In The George S. Patton Papers: Library of Congress, July 13, 1943.

Letter, Mrs. George E. Rubretz to Patton. In The George S. Patton Papers: Library of Congress, April 20, 1945.

Letter, Mrs. Henry Godfrey to Patton. In The George S. Patton Papers: Library of Congress, November 8, 1943.

Letter, Mrs. Henry McLain to Patton. In The George S. Patton Papers: Library of Congress, April 29, 1944.

Letter, Mrs. John Logan to Patton. In The George S. Patton Papers: Library of Congress, July 27, 1943.

Letter, Mrs. Louis J. Stricker to Patton. In The George S. Patton Papers: Library of Congress, August 15, 1944

Letter, Mrs. M. J. Morse to Patton. In The George S. Patton Papers: Library of Congress, 1945.

Letter, Mrs. S. M. Apple to Patton. In The George S. Patton Papers: Library of Congress, August 12, 1944.

Letter, Patton to Betty Drake. In The George S. Patton Papers: Library of Congress, November 1, 1943.

Letter, Patton to Charles H. Thomas. In The George S. Patton Papers: Library of Congress, undated.

Letter, Patton to Cheek. In The George S. Patton Papers: Library of Congress, September 24, 1943.

Letter, Patton to Daspit. In The George S. Patton Papers: Library of Congress, May 4, 1944.

Letter, Patton to Elizabeth Maguire. In The George S. Patton Papers: Library of Congress, April 14, 1943.

Letter, Patton to Fincher. In The George S. Patton Papers: Library of Congress, January 29, 1944.

Letter, Patton to Jack Brown. In The George S. Patton Papers: Library of Congress, February 7, 1945.

Letter, Patton to Mr. Walter B. Stewart. In The George S. Patton Papers: Library of Congress, September 5, 1944. 
Letter, Patton to Mrs. Apple. In The George S. Patton Papers: Library of Congress, September 10, 1944.

Letter, Patton to Ralph Pitts. In The George S. Patton Papers: Library of Congress, May 10, 1943.

Letter, Patton to Richardson. In The George S. Patton Papers: Library of Congress, August 10, 1943.

Letter, Patton to Robert Patton Makielski. In The George S. Patton Papers: Library of Congress, November 1, 1943.

Letter, Patton to Rubretz. In The George S. Patton Papers: Library of Congress, May 8 , 1945.

Letter, Patton to Savage. In The George S. Patton Papers: Library of Congress, September 1, 1944.

Letter, Patton to Sonny Hill. In The George S. Patton Papers: Library of Congress, December 10, 1943.

Letter, Paul Wurtzel to West Point Museum Curator. In The General George Patton Museum Archives, May 3, 1968.

Letter, R.D. Brown to Patton. In The George S. Patton Papers: Library of Congress, February 1, 1944.

Letter, R.H. Wilson to West Point Museum. In The General George Patton Museum Archives, November 23, 1972.

Letter, Ralph Pitts to Patton. In The George S. Patton Papers: Library of Congress, March 26, 1943.

Letter, Reverand G. Cyril Green to Patton. In The George S. Patton Papers: Library of Congress, August 16, 1944.

Letter, Robert Patton Makielski to Patton In The George S. Patton Papers: Library of Congress, October 15, 1942.

Letter, Room 3 Class to Patton. In The George S. Patton Papers: Library of Congress, undated.

Letter, Rose La Barton to GSP. In The George S. Patton Papers: Library of Congress, January 7, 1945.

Letter, Ruth Irene Daspit to Patton. In The George S. Patton Papers: Library of Congress, April 7, 1944.

Letter, Sonny Hill to Patton. In The George S. Patton Papers: Library of Congress, December 19, 1943.

Letter, T.R. Uthus. October 12, 1944.

Letter, Theodore Macejko to Patton. In The George S. Patton Papers: Library of Congress, January 31, 1945.

Letter, Theodore R. Stillwell to Patton. In The George S. Patton Papers: Library of Congress, March 20, 1943.

Letter, Therese S. Jose to Patton. In The George S. Patton Papers: Library of Congress, April 23, 1944.

Letter, Thomas McNulty, World Wars Tank Corps Association. In The General George Patton Museum Archives, October 20, 1972.

Letter, Thomas Sharkey to Patton. In The George S. Patton Papers: Library of Congress, May 31, 1945. 
Letter, Tom Bush to Patton. In The George S. Patton Papers: Library of Congress, undated.

Letter, Walter Anderson to Patton. In The George S. Patton Papers: Library of Congress, August 20, 1944.

Letter, William R. Cheek to Patton. In The George S. Patton Papers: Library of Congress, August 19, 1943.

Telegraph, Ira Lewis to Patton. In George S. Patton Papers: Library of Congress, December 1945.

Thank You Card, Yvette Charpertier to Patton. In The George S. Patton Papers: Library of Congress, January 18, 1945.

$\underline{\text { Published Primary Sources (Books) }}$

Allen, Robert S. Lucky Forward, the History of Patton's Third U.S. Army. New York: Vanguard Press, 1947.

Allen, Robert S., and John Nelson Rickard. Forward With Patton: The World War II Diary of Colonel Robert S. Allen. Lexington, Kentucky: University Press of Kentucky, 2017.

Ayer, Frederick. Before the Colors Fade: A Portrait of a Soldier. Boston, MA: Houghton Mifflin, 1964.

Bradley, Omar Nelson. A Soldier's Story. Westport, Conn.: Greenwood Press, 1975.

Bradley, Omar Nelson, and Herman Finkelstein. A Soldier's Story. New York: Holt, 1951.

Codman, Charles R. Drive. Boston: Little, 1957.

Eisenhower, Dwight D. Crusade in Europe. Garden City, N.Y.,: Garden City Books, 1952.

Famous American Military Leaders of World War II. New York: Dodd, Mead \& Co., 1962.

Hatch, Alden. General George Patton: Old Blood \& Guts. New York: Sterling Pub. Co., 2006.

- George Patton, General in Spurs. New York: Messner, 1950.

Hirsch, Phil, ed. Fighting Generals. New York: Pyramid Books, 1960.

Leopold, Christopher. Blood and Guts is Going Nuts. London: Lemon Tree Press, 1976.

Mellor, William Bancroft. General Patton: The Last Cavalier. New York: Putnam, 1971.

- Patton, Fighting Man. New York: Putnam, 1946.

Nolan, Frederick W. The Algonquin Project. New York: Morrow, 1974.

O'Reilly, Bill, and Martin Dugard. Killing Patton: The Strange Death of World War II's Most Audacious General. New York: Henry Holt and Company, 2014.

Pacheco, Ferdie. Who Killed Patton? Indianapolis, IN: AuthorHouse, 2004.

Patton, Benjamin, and Jennifer Scruby. Growing Up Patton. New York: Berkley Caliber, 2012.

Patton, George S., and Martin Blumenson. The Patton Papers. 2 vols. Boston, MA: Houghton Mifflin, 1972.

Patton, George S., Paul D. Harkins, and Beatrice Banning Ayer Patton. War As I Knew It. Boston: Houghton Mifflin Co., 1947. 
Patton, Robert H. The Pattons: A Personal History of an American Family. New York: Crown Publishers, 1994.

Pearl, Jack. Blood-and-Guts Patton: The Swashbuckling Life Story of America's Most Daring and Controversial General. Derby, Connecticut: Monarch Books, 1961.

Perry, Milton F., and Barbara W. Parke. Patton and His Pistols: The Favorite Side Arms of General George S. Patton, Jr. Harrisburg, Pennsylvania: Stackpole Co., 1957.

Puryear, Edgar F. Nineteen stars. Washington, D.C.: Coiner Publications, 1971.

Semmes, Harry Hodges. Portrait of Patton. New York: Appleton-Century-Crofts, 1955.

Shoemaker, Robert Hilles, and Leonard Allen Paris. Famous American Generals. New York: Thomas Y. Crowell Company, 1946.

Totten, Ruth Ellen Patton, and James Patton Totten. The Button Box: A Daughter's Loving Memoir of Mrs. George S. Patton. Columbia: University of Missouri Press, 2005.

Wallace, Brenton Greene. Patton and His Third Army. Washington, D.C.: Military Service Publishing Company, 1946.

Warrior; The Story of General George S. Patton. New York: Putnam, 1967.

Wellard, James Howard. The Man in a Helmet: The Life of General Patton. London: Eyre \& Spottiswoode, 1947.

Wilcox, Robert K. Target: Patton: The Plot to Assassinate General George S. Patton. Washington, D.C.: Regnery Publising, 2010.

$\underline{\text { Periodicals }}$

"Auld Lang Syne." TIME, October 15, 1945.

"Coliseum Jammed for Spectacular Tribute to Heroes." Los Angeles Examiner, June 10, 1945.

Collins, Whit. "Patton: Guns Made Him Great." Guns \& Ammo 1971, 30-33, 80-82.

"Command: Death \& the General." TIME, December 31, 1945.

Creel, George. "Patton at the Pay-Off." Collier's, January 13, 1945.

"Exhibit Reveals Another Side of General." The Eagle Tribune, April 24, 2004.

Field, John. "Patton of the Armored Force: "Old Blood and Guts" Leads U.S. Troops in Morocco and Pines to Challenge Rommel to Personal Combat." LIFE, November 30, 1942.

"General Patton." Newsweek, December 17, 1945.

"General Patton's Indiscretion." The Christian Century LX, no. 49 (December 8, 1943 1943): 1427-28.

"Huge Coliseum Crowd Cheers Heroes' Appeal." Los Angeles Examiner, June 10, 1945. Jose, Therese S. "Editorial." Pony Express Courier, December 1943.

O'Connor, John J. "TV Weekend; George C. Scott in 'Last Days of Patton'." The New York Times, September 12, 1986.

Ogan, Ronald A. "Patton's Peacemaker." American Rifleman 1986.

Painton, Frederick C. "Old Man of Battle." Reader's Digest (September 1943): 8-12.

"Patton \& the Devil." TIME, October 1, 1945.

"Patton, The Soldier." The New York Times, October 9, 1945.

Patton, George S. "Armored Cars with Cavalry." Cavalry Journal (1924).

—. "The Effects of Weapons on War." Cavalry Journal (November 1930). 
— . "The Present Saber: It's Form and the Use for Which It Was Designed." Cavalry Journal, no. April (1917).

__. "Tanks in Future Wars." Cavalry Journal (May 1920).

"Patton Rebuked." The Scholastic, October 22, 1945.

"Patton Regilded." TIME, August 28, 1944.

"Pulling for Patton." Times-Picayune, New Orleans, Louisiana, December 11, 1945.

"Remove Patton from Germany." The New Republic (October 1, 1945).

Rosevich, Joseph D. "The Patton Nobody Knows." SAGA, , April 1953.

"Salute for Victors." Newsweek, June 18, 1945.

Shane, Ted. "These Are The Generals - Patton." Saturday Evening Post, February 6, 1943.

Sheean, Vincent. "The Patton Legend - And Patton As Is." The Saturday Evening Post, June 23, 1945.

"The Mouth." Newsweek, October 15, 1945.

"Untitled." Indianapolis News, December 1945.

"Untitled." Inside the Turret, November 11, 1953.

"Untitled." New York Journal, December 1945.

"Untitled." New York Journal, December 11, 1945.

"Untitled." TIME April 9, 1945.

War Heroes. Vol. No. 5, July-September 1943.

Wilson, David. "Patton." Sight and Sound 39 (Summer 1970): 160.

Documentaries, Films, and Movies

Brass Target, directed by John Hough, written by Frederick Nolan and Alvin Boretz, featuring Sophia Loran and George Kennedy (1978, Metro Goldwyn Mayer: 2012 Warner Archives), DVD.

Famous Military Generals (2017, GAJ Docu-Films), steaming online video, https://www.amazon.com/Famous-Military-Generals-Documentary$\mathrm{IF} / \mathrm{dp} / \mathrm{B} 078 \mathrm{H} 2 \mathrm{~B} 5 \mathrm{G} 1$.

Last Days of Patton, directed by Delbert Mann, written by William Luce, featuring George C. Scott (1986, CBS: BCI/Eclipse, 2004), DVD.

Patton, directed by Franklin J. Schaffner, written by Francis Ford Coppola, Edmund H. North, featuring George C. Scott, Karl Malden, and Stephen Young (1970, $20^{\text {th }}$ Century Fox: $20^{\text {th }}$ Century Fox Home Entertainment, 2006), DVD.

Patton: A Genius for War, directed by Don Horan, written by Norman Stahl, featuring Jack Perkins, season 7, episode 29 (2004, A\&E DVD Archives), DVD.

Patton $360^{\circ}$, written by Samuel K. Dolan and Jim Hense, aired April 10-June 26, 2009 on History.

"The Famous Third Army," Big Picture, episode 217, in Records of the Office of the Chief Signal Officer (RG111), National Archives and Records Administration (Washington, D.C.: Army Pictorial Service, 1952) 28:00.

"The General Patton Story," Big Picture, narrated by Ronald Reagan, episode 468, in Records of the Office of the Chief Signal Officer (RG111), National Archives and Records Administration (Washington, D.C.: Army Pictorial Service, 1960) 28:00. 
WWII: Great American Generals (2018, Sprocket Flicks), streaming online video, https://www.amazon.com/WWII-American-Generals-GeneralPatton/dp/B07949L47C.

\section{$\underline{\text { Digital Platforms }}$}

Bowlin, Ben and Noel Brown. "A Grave Mistake: The Story of Patton's 'Abandoned Rear," July 18, 2019. In Ridiculous History, produced by iHeartRadio, podcast, 30:00, https://www.podbean.com/podcast-detail/4rdih-5e1ff/Ridiculous-HistoryPodcast//page/3.

Ellis, Ryan and Bev Ellis. "Patton," December 15, 2014. In The Top 100 Project, podcast, 40:00, http://www.top100project.com.

Willink, Jocko. "Battle is The Most Magnificent Competition in which a Human Can Indulge. Patton's General Orders," January 22, 2020. Episode 213 in Jocko Podcast, podcast, 2:32:00, https://jockopodcast.com/.

Willink, Jocko. "How to Overcome Our Natal Defects. Patton's General Instructions and Keys to Victory," January 29, 2020. Episode 214 in Jocko Podcast, podcast, 2:16:45, https://jockopodcast.com/.

Willink, Jocko. “'The Motivation' - General Patton, Jiu Jitsu for Streets, Home Gyms, Hero Workship," February 10, 2016. Episode 9 in Jocko Podcast, podcast, 2:13:00, https://jockopodcast.com/.

"Patton," May 23, 2012. In Man Cave Movie Review, podcast, 1:12:00, http://www.mancavemoviereview.com.

"Patton," February 4, 2019. Season 1, episode 15 in WWII Service on Celluloid, podcast, 53:00, https://www.nationalww2museum.org/war/service-celluloidpodcast.

“The Death of General Patton," December 21, 2015. In BBC World Service, Witness Word War II, podcast, 09:00, http://bbc.co.uk.

\section{SECONDARY SOURCES}

\section{$\underline{\text { Published Works }}$}

Aaronovitch, David. Voodoo Histories: The Role of the Conspiracy Theory in Shaping Modern History. New York: Riverhead Books, 2010.

Adams, Fred. George S. Patton: Everything You Need To Know. Emereo Publishing, 2014.

Allen, Robert S., and John Nelson Rickard. Forward With Patton: The World War II Diary of Colonel Robert $S$. Allen. Lexington, Kentucky: University Press of Kentucky, 2017.

Ambrose, Stephen E. Fateful Friendship: Eisenhower and Patton. New World City, Inc., 2014.

Appleby, Joyce, Lynn Hunt, and Margaret C. Jacob. Telling the Truth About History. New York: Norton, 1994.

Axelrod, Alan. Patton: A Biography. New York: Palgrave Macmillan, 2006. 
- Patton's Drive: The Making of America's Greatest General. Guilford, CT: Lyons Press, 2009.

Bandura, Albert. "The Explanatory and Predictive Scope of Self-Efficacy Theory." Journal of Social and Clinical Psychology 4, no. 1 (1986): 359-73.

. "Self-efficacy: Toward a Unifying Theory of Behavioral Change."

Psychological Review 84, no. 2 (1977): 191.

Bankes, James. WWII: General George Patton/The Dark Mind of a Military Genius. Self Published, 2015.

Baron, Richard, Abe Baum, and Richard Goldhurst. Raid!: The Untold Story of Patton's Secret Mission. New York: Putnam, 1981.

Barron, Leo. Patton at the Battle of the Bulge: How the General's Tanks Turned the Tide at Bastogne. New York, New York: NAL Caliber, 2014.

- Patton's First Victory: How General George Patton Turned the Tide in North Africa and Defeated the Afrika Korps at El Guettar. Guilford, Connecticut: Stackpole Books, 2018.

Belk, Russel W., et al. "Collectors and Collecting." Advances in Consumer Research 15 (1988): 548-553. Accessed September 10, 2020. https://www3.nd.edu/ jsherry/pdf/1988/Collectors\%20and\%20Collecting.pdf.

Bell, Kenton, ed., "Verstehen," in Open Education Sociology Dictionary. Accessed July 2, 2020, https://sociologydictionary.org/verstehen.

Berger, Arthur Asa. What Objects Mean: An Introduction to Material Culture. Walnut Creek, CA: Left Coast Press, 2014.

Bilder, Michael C., and James G. Bilder. A Foot Soldier for Patton: The Story of a "Red Diamond" Infantryman with the U.S. Third Army. Drexel Hill, PA: Casemate, 2008.

Blair, Omar N. Bradley and Clay. A General's Life. New York: Simon and Schuster, 1983.

Blumenson, Martin. The Many Faces of George S. Patton, Jr. The Harmon Memorial Lectures in Military History. Colorado Springs: U.S. Air Force Academy, 1972.

-. Patton: The Man Behind the Legend, 1885-1945. New York: Morrow, 1985.

Blumenson, Martin, and Kevin Hymel. Patton: Legendary Commander. Washington, D.C.: Potomac Books, 2008.

Brighton, Terry. Patton, Montgomery, Rommel: Masters of War. New York: Crown, 2009.

Bronfenbrenner, Urie. The Ecology of Human Development: Experiments by Nature and Design. Cambridge, MA: Harvard University Press, 1979.

Brown, Andrew, Ian Colville, Annie Pye. "Making Sense of Sensemaking in Organizational Studies." Organizational Studies 36, no. 2 (2015): 265-77.

Byrant, Anthony. Grounded Theory and Grounded Theorizing: Pragmatism in Research Practice. New York: Oxford University Press, 2017.

Camacho, Major Lawrence Fr. The Leadership Development of Dwight D. Eisenhower and George S. Patton Jr. Audiobook found on Apple Books, 2015

Campbell, Joseph. The Hero with a Thousand Faces. Princeton, NJ: Princeton University Press, 2004. 
Cantor, Dolf Zillman and Joanne. "Directionality of Transitory Dominance as a Communication Variable Affecting Humor Appreciation." Journal of Personality and Social Psychology 24, no. 2 (1972): 191-98.

Carlyle, Thomas. On Heroes, Hero Worship, and the Heroic in History. Lexington, KY: Another Leaf Press, 2012.

Christian, Sue Ellen and Leah M. Omilion-Hodges. "Emotional Reactions to Sports Heroes' Rise and Fall: Application of Affective Disposition Theory Via the Hero Narrative." Journal of Mass Communication \& Journalism 4, no. 6 (2014).

Clarke, Thomas W. George S. Patton's Typical Soldier: A Memoir of Thomas W. (Wally) Clarke, Company D, 101st Infantry, 26th Division, Third Army. Lancaster, PA: American Historical Pub., 2009.

"Commodification," in Open Education Sociology Dictionary, accessed September 10, 2020, https://sociologydictionary.org/commodification/.

Conle, Carola and Michelle Boone. "Local Heroes, Narrative Worlds, and the Imagination: The Making of a Moral Curriculum." Curriculum Inquiry 38, no. 1 (January 2008): 7-37.

Cook-Sather, Alison. "Newly Betwixt and Between: Revising Liminality in the Context of a Teacher Preparation Program." Anthropology and Education Quarterly 37 (2006): 110-27.

Creswell, John W. Qualitative Inquiry and Research Design: Choosing Among Five Traditions. Thousand Oaks, CA: Sage, 1998.

D'Este, Carlo. Eisenhower: A Soldier's Life. New York: Henry Holt and Company, 2002.

_. Patton: A Genius for War. New York: Harper Collins Publishers, 1995.

Durkheim, Emile, and Karen E. Fields. The Elementary Forms of Religious Life. New York: Free Press, 1995.

Durkheim, Emile and Steven Lukes, ed. Emile Durkheim: The Division of Labor in Society. New York: Free Press, 2014.

Eagleton, Terry. The Idea of Culture. Malden, MA: Blackwell, 2000.

Eagly, Alice H. "When Passionate Advocates Meet Research on Diversity, Does the Honest Broker Stand a Chance?" Journal of Social Issues 72, no. 1 (2016): 199222.

Emerson, Ralph Waldo. Essays and Poems by Ralph Waldo Emerson. New York: Barnes \& Noble Classics, 2004.

- Representative Men. Lexington, KY, 2016.

Engelhardt, Tom. The End of Victory Culture: Cold War America and the Disillusioning of a Generation. Amherst: University of Massachusetts Press, 2007.

Farago, Ladislas. The Last Days of Patton. New York: McGraw-Hill, 1981.

- Patton: Ordeal and Triumph. London: Barker, 1966.

Fischer, Claude S. "Paradoxes of American Individualism." Sociological Forum 23, no. 2 (2008): 363-72.

Fontenot, Gregory. "Seeing Red: Creating a Red-Team Capability for the Blue Force." Military Review (September 2005).

Forty, George. The Armies of George S. Patton. London: Arms and Armour, 1996. . Patton's Third Army at War. Shepperton: I. Allan, 1978. 
Frankel, Nat, and Larry Smith. Patton's Best: An Informal History of the 4th Armored Division. New York: Hawthorn Books, 1978.

Genoways, Hugh G., ed. Museum Philosophy for the Twenty-first Century. Lanham, Maryland: AltaMira Press, 2006.

Gerth, H.H. and C. Wright Mills, eds. From Max Weber: Essays in Sociology. New York: Oxford University Press, 1946.

General George S. Patton: Operational Art, Battle Command Lessons in the Second World War. E-book: Progressive Management, 2014.

Gillis, John R., ed. Commemoration: The Politics of National Identity. Princeton, NJ: Princeton University Press, 1996.

Glaser, Barney G. "The Constant Comparative Method of Qualitative Analysis." Social Problems 12, no. 4 (1965): 436-45.

- Theoretical Sensitivity: Advances in the Methodology of Grounded Theory. Mill Valley, Calif.: Sociology Press, 1978.

Goethals, George R. and Scott T. Allison. "Making Heroes: The Construction of Courage, Competence, and Virtue." In Advances in Experimental Psychology, edited by J.M. Olson and M.P. Zanna, 183-235. San Diego: Elsevier, 2012.

Gole, Henry G. General William E. DePuy: Preparing the Army for Modern War. Lexington: University Press of Kentucky 2008.

Gott, Patricia Probert. General Patton Rescues the Horses. Norway, Maine: PRGott Books, 2016.

Hajjar, Remi M. "Emergent Postmodern U.S. Military Culture." Armed Forces and Society 40, no. 1 (2013): 118-45.

. "A New Angle on the U.S. Military's Emphasis on Developing Cross-Cultural Competence: Connecting In-Ranks' Cultural Diversity to Cross-Cultural Competence," Armed Forces and Society (January 2010).

Halbwachs, Maurice. On Collective Memory. Chicago: University of Chicago Press, 1992.

Hanson, Victor Davis. "What Would Patton Say About the Present War?" Imprimis 33, no. 10 (October 2004).

Herbert, Paul H. Deciding What Has to Be Done: General William E. DePuy and the 1976 Edition of Field Manual 100-5 Operations. Fort Leavenworth, KS: U.S. Army Command and General Staff College, 1988.

Higgins, George A. "Operational Tenets of Generals Heinz Guderian and George S. Patton, Jr." U.S. Army Command and General Staff College, 1985.

Hirshson, Stanley P. General Patton: A Soldier's Life. New York: Harper Collins, 2002.

Hobbs, A. Plato and the Hero: Courage, Manliness and the Impersonal Good. Cambridge: Cambridge University Press, 2000.

Hogg, Ian V. The Biography of General George S. Patton. London, New York: Hamlyn, 1982.

Hunter, James D. Culture Wars: The Struggle to Define America. New York: Basic Books, 1991.

Huntington, Samuel P. The Soldier and the State: The Theory and Politics of CivilMilitary Relations. Cambridge, Mass.: Belknap Press, 1985.

Irwin-Zarecka, Iwona. Frames of Remembrance: The Dynamics of Collective Memory. New Brunswick, New Jersey: Tranaction Publishers, 1994. 
Irzyk, Albin F. Oral History conducted with Nathan C. Jones (November 2018). . Patton's Juggernaut: The Rolling 8-Ball. Oakland, Oregon: Elderberry Press, Inc., 2017.

-A Warrior's Quilt of Personal Military History. Raleigh, NC: Ivy House Publishing Group, 2011.

Jessup, John E., Jr. and Robert W. Coakley. A Guide to the Study and Use of Military History. Washington, D.C.: U.S. Government Printing Office, 1982.

Johnson, Whitney Pope and Barclay D. "Inside Organic Solidarity." American Sociological Review 48, no. 5 (October 1983): 681-92.

Jung, C. G. The Archetypes and the Collective Unconscious. Translated by R. F. C. Hull. Princeton University Press, 1990. 1959.

Kansteiner, Wulf. "Finding Meaning in Memory: A Methodological Critique of Collective Memory Studies." History and Theory 41, no. 2 (May 2002): 179-97.

Kelly, Orr. King of the Killing Zone. New York: W.W. Norton, 1989.

Khanam, Kazi Zainab, Gautam Srivastava, and Vijay Mago. "The Homophily Principle in Social Network Analysis.” Proc. ACM Meas. Anal. Comput. Syst. 37, no. 4 (May 2020): Article 111: 1-28.

Koch, Oscar W., and Robert G. Hays. G-2: Intelligence for Patton. Atglen, PA: Schiffer Military History, 1999.

Lande, D.A. I Was With Patton: First Person Accounts of WWII in George S. Patton's Command. St. Paul, MN: MBI Publishing Co., 2002.

Laney, Scot II. In Case of Doubt: Attack!: General George S. Patton and Corporate Leadership. Lulu.com, 2011.

Linenthal, Edward Tabor. Changing Images of the Warrior Hero in America: A History of Popular Symbolism. New York: E. Mellen, 1982.

Lovelace, Alexander G. "The Image of a General: The Wartime Relationship Between General George S. Patton Jr and the American Media." Journalism History 40, no. 2 (2014): 108-20.

Luciano, Eugene W. Our Blood and His Guts!: Memoirs of One of General Patton's Combat Soldiers. Chapel Hill, NC: Professional Press, 1995.

Lukianoff, Greg, and Jonathan Haidt. The Coddling of the American Mind: How Good intentions and Bad Ideas are Setting Up a Generation for Failure. New York City: Penguin Books, 2018.

Lundquist, Jennifer Hickes. "Ethnic and Gender Satisfaction in the Military: The Effect of a Meritocratic Institution." American Sociological Review 73, no. 3 (2008): 477-96.

Lyon, Christopher S.M. A Holy Warrior in an Unholy Age. Theodosian Walls Publications, 2014.

MacCoun, Robert J. and William M. Hix. "Unit Cohesion and Military Performance." In Sexual Orientation and U.S. Military Personnel Policy: An Update of RAND's 1993 Study, 137-65. Santa Monica, CA: RAND Corporation, 2010.

MacDonald, Heather. The Diversity Delusion: How Race and Gender Pandering Corrupt the University and Undermine Our Culture. New York: St. Martin's Press, 2018.

Macdonald, Sharon and Gordan Fyfe, eds. Theorizing Museums. Oxford, U.K.: Blackwell Publishing, 1999. 
Martin, Frank Wayne. Patton's Lucky Scout. Milwaukee, WI: Crickhollow Books, 2009. Mikolashek, Jon, and Paul T. Mikolashek. Blood, Guts, and Grease: George S. Patton in World War I. Lexington, Kentucky: University Press of Kentucky, 2019.

Miller, Merle. Ike the Soldier: As They Knew Him. New York: Putnam's Sons, 1987.

Moore, Joseph Ellis and Robert. School for Soldiers: West Point and the Profession of Arms. Oxford University Press, 1974.

Morningstar, James Kelly. Patton's Way: A Radical Theory of War. Annapolis, Maryland: Naval Institute Press, 2017.

Nye, Roger H. The Patton Mind: The Professional Development of an Extraordinary Leader. Garden City Park, New York: Avery, 1993.

. "Whence Patton's Military Genius?" Parameters 21, no. 4 (December 1991): 60-73.

Odom, Charles B. General George S. Patton and Eisenhower. New Orleans, Louisiana: World Picture Productions, 1985.

Orbach, Robert. Not All Hell: Two Hundred Sixty-Five Days in General George Patton's Third Army. Tulsa, OK: Out on A Limb Publishing, 2003.

Patton, Benjamin, and Jennifer Scruby. Growing Up Patton. New York: Berkley Caliber, 2012.

Patton, George S., and Kevin Hymel. Patton's Photographs: War as He saw It. Washington, D.C.: Potomac Books, 2006.

Patton, Robert H. The Pattons: A Personal History of an American Family. New York: Crown Publishers, 1994.

Peterson, Jordan B. Maps of Meaning: The Architecture of Belief. New York: Routledge, 1999.

Phillips, Kendall R., ed. Framing Public Memory. Tuscaloosa: University of Alabama Press, 2004.

Porr, Martin. "Lives and Lines: Integrating Molecular Genetics, the 'Origins of Modern Humans' and Indigenous Knowledge." In Long History, Deep Time: Deepening Histories of Place, edited by Ann McGrath and Mary Anne Jebb. Canberra, Australia: Australian National University Press, 2015.

Province, Charles M. "Guns of General Patton." Guns December 1986, 36-39, 77-79.

- I Was Patton's Doctor: The Reminiscences of Colonel B. Odom, M.D. CMP Productions, 2011.

—, ed. Military Essays and Articles by George S. Patton, Jr. 1885-1945. San Diego, CA: The George S. Patton, Jr. Historical Society, 2002.

—. Patton's One-Minute Messages: Tactical Leadership Skills for Business Management. Novato, California: Presidio, 1995.

- The Unknown Patton. New York: Hippocrene Books, 1983.

Reynolds, Michael Frank. Monty and Patton: Two Paths to Victory. Barnsley, South Yorkshire: Pen \& Sword Military, 2010.

Rickard, John Nelson. Advance and Destroy: Patton as Commander in the Bulge. Lexington: University Press of Kentucky, 2011.

—. Patton at Bay: The Lorraine Campaign, September to December, 1944. Westport, Connecticut: Praeger, 1999.

Ricks, Thomas. The Generals: American Military Command from World War II to Today. New York: Penguin Press, 2012. 
Rogowsky, Beth A., Barbara M. Calhoun, and Paula Tallal. "Does Modality Matter? The Effects of Reading, Listening, and Dual Modality on Comprehension." Sage July-September (2016): 1-9.

Rohmer, Richard H. Patton's Gap: An Account of the Battle of Normandy, 1944. New York: Beaufort Books, 1981.

Romjue, John L., Susan Canedy, and Anne W. Chapman. Prepare the Army for War: A Historical Overview of the Army Training and Doctrine Command 1973-1993. Fort Monroe, VA: TRADOC, 1993.

Rosenberg, Tracy Jean. "History Museums and Social Cohesion: Building Identity, Bridging Communities and Addressing Difficult Issues." Peabody Journal of Education 86, no. 2 (2011): 115-28.

Rosenzweig, Roy and David Thelen. The Presence of the Past: Popular Uses of History in American Life. New York, NY: Columbia University Press, 1998.

Runkle, Benjamin. Generals in the Making: How Marshall, Eisenhower, Patton, and their Peers Became the Commanders Who Won World War II. Guilford, Connecticut: Stackpole Books, 2019.

Sarantakes, Nicholas Evan. Making Patton: A Classic War Film's Epic Journey to the Silver Screen. Lawrence: University Press of Kansas, 2012.

Schofield, Peter Lambert and Phillipp, ed. Making History: An Introduction to the History and Practices of a Discipline. New York: Routledge, 2004.

Shanafelt, Robert. "The Nature of Flag Power: How Flags Entail Dominance, Subordination, and Social Solidarity." Politics and the Life Sciences 27, no. 2 (2008): 13-27.

Showalter, Dennis E. Patton and Rommel: Men of War in the Twentieth Century. New York: Berkley Caliber, 2005.

Smith, C. Cabanne. My War Years: 1940-1946. Service on Gen. Patton's Third Army Staff. Houston, TX: Rosenlaui Publishing Services, Inc., 1989.

Stillman, Richard J. General Patton's Secret Missions. New Orleans, Louisiana: R. J. Stillmlan Co., 2005.

Stillman, Richard Joseph. George S. Patton's Timeless Leadership Principles. New Orleans, LA: Richard Stillman Co., 1998.

Stone, Philip and Richard Sharpley. "Consuming Dark Tourism: A Thanatological Perspective." Annals of Tourism Research 35, no. 2 (2008): 574-595.

Strauss, Anselm and Juliet Corbin. Basics of Qualitative Research: Grounded Theory Procedures and Techniques. Newbury Park, CA: Sage Publications, 1990.

Suid, Lawrence H. Guts \& Glory: The Making of the American Military Image in Film. Lexington, KY: The University Press of Kentucky, 2002.

Swain, Richard M., ed. Selected Papers of General William E. DePuy. Fort Leavenworth, KS: U.S. Army Command and General Staff College, 1973.

Toffler, Heidi Toffler and Alvin. War and Antiwar: Making Sense of Today's Global Chaos. London: Warner Books, 1993.

Trofanenko, Brenda. "The Public Museum and Identity: Or, the Question of Belonging." Counterpoints 272 (2006): 95-109.

Tucker, Robert C., ed. The Marx-Engels Reader. New York: W.W. Norton \& Company, 1978. 
Turner, Victor W. The Ritual Process: Structure and Anti-structure. Chicago,: Aldine Pub. Co., 1969.

. The Ritual Process: Structure and Anti-structure. New York: Aldine De Gruyter, 1969.

Van Creveld, Martin. Supplying War: Logistics from Wallenstein to Patton. Cambridge, New York: Cambridge University Press, 2004.

van Dijk, H., M.L. van Engen, and D. van Knippenberg. "Defying Conventional Wisdom: A Meta-Analytical Examination of the Differences Between Demographic and Job-related Diversity Relationships with Performance." Organizational Behavior and Human Decision Processes 119 (2012): 38-53.

Veblen, Thorstein. The Theory of the Leisure Class. New York: Penguin Books, 1994. Weber, Max, Hans Heinrich Gerth, and C. Wright Mills. From Max Weber: Essays in Sociology. New York: Oxford University Press, 1946.

Weick, Karl E. Sensemaking in Organizations. Thousand Oaks, CA: Sage Publications, Inc., 1995.

Wellard, James. Following Patton: War Correspondent James Wellard with General George Patton and the Third Army. Uncommon Valor Press, 2015.

Whiting, Charles. Patton's Last Battle. Havertown, Pennsylvania: Casemate, 2002.

Wilson, Dale. Treat 'em Rough: The Birth of American Armor, 1917-20. Novato, CA: Presidio, 1989.

Zillman, Dolf and Joanne Cantor. "Directionality of Transitory Dominance as a Communication Variable Affecting Humor Appreciation." Journal of Personality and Social Psychology 24, no. 2 (1972): 191-98.

\section{$\underline{\text { Websites }}$}

"A Bust of General Patton at the Patton Memorial, Avranches, Normandy, France." https://www.alamy.com/stock-photo-a-bust-of-general-patton-at-the-pattonmemorial-avranches-normandy-11849887.html.

"AFI's 100 Years...100 Movies: The 100 Greatest American Movies of All Time." https://www.afi.com/100Years/movies.aspx.

"Army Defends Best in Nation Title at National Trophy Pistol Matches." https://www.army.mil/article/152918/

"Army Demographics FY16 Army Profile." https://m.goarmy.com/content/dam/goarmy/downloaded_assets/pdfs/advocatesdemographics.pdf

"Badass of the Week." http://www.badassoftheweek.com/patton.html.

"Bart the General/References." https://simpsons.fandom.com/wiki/Bart the_General/References.

"Books Written About Napoleon Bonaparte History Essay." https://www.ukessays.com/essays/history/books-written-about-napoleonbonaparte-history-essay.php.

Brown, DeNeen L. "Frederick Douglass Statue Torn Down in Rochester, N.Y., on Anniversary of his Famous Fourth of July Speech," July 6, 2020, https://www.washingtonpost.com/history/2020/07/06/frederick-douglass-statuerochester-attacked. 
"Confidence in Institutions." https://news.gallup.com/poll/1597/confidenceinstitutions.aspx.

Conon, Neal. "Top Military Officers Abandon Armed Forces." https://www.npr.org/2011/01/13/132904846/top-military-officers-abandonarmed-forces.

"EDSITEment!: The Best of the Humanities on the Web." https://edsitement.neh.gov/launchpad-speech-third-army-george-s-patton-jr.

Gallup. "Greatest American Military General of All Time? Public Says Patton, Eisenhower and MacArthur." Gallup, http://www.gallup.com/poll/2236/greatestamerican-military-general-all-time-public-says-patton.aspx.

"Gen. Patton Pilgrimage Southern California." http://www.bargaintravelwest.com/California_Patton_Memorial_San_Gabriel.ht $\mathrm{m}$.

"General Patton." http://www.GeneralPatton.com.

"General Patton Memorial Museum." https://www.patton.lu.

"The General's Personal Sidearms." http://www.pattonhq.com/unkown/chap05.html.

"George Patton: A Man Must Know His Destiny." http://zenpencils.com/comic/georgepatton-a-man-must-know-his-destiny/.

"Green Meadows Farm." http://www.gmfarm.com.

Greenwood, Max. "George Washington's Virginia church taking down his memorial." https://thehill.com/blogs/blog-briefing-room/news/357608-george-washingtonsvirginia-church-taking-down-his-memorial.

"Health Center holds final Patton remembrance ceremony." (November 9, 2011). https://www.army.mil/article/69466/.

"Heart of Armor School named for Army legend." https://www.army.mil/article/79550/heart_of_armor_school_named_for_army_le gend.

Hipps, Tim. "Hall of Fame Inductee Patton Still Inspires Soldiers." http://www.army.mil/article/183681.

"Historic House escapes demolition, rededication Friday." https://www.army.mil/article/50842/historic_house_escapes_demolition_rededica tion_friday.

"History of Dyslexia." http://www.dyslexia-aware.com/dawn/history-of-dyslexia.

"Introducing Patton Hall." https://www.army.mil/article/174500/introducing_patton_hall.

Keane, Michael. "What Would Patton Do?" http://www.theblaze.com/contributions/what-would-patton-do.

Kelly, Ryan M. "Memorial Day Commemoration, "Patton" Screening." http://www.dailyprogress.com/news/local/memorial-day-commemoration-pattonscreening/collection_2db32d6c-e44d-11e3-a430-001a4bcf6878.html.

Lanning, Michael Lee. The Military Top 100. Secaucus, New Jersey: Citadel Press, 1996.

"Legacy Sports." http://helenpatton.com/legacysports/.

"Memorial "Camp Patton" Nehou." https://www.tracesofwar.com/sights/20790/Memorial-Camp-Patton-Nehou.htm. 
"Military Tactics: The George Patton Quiz."

https://quizzes.howstuffworks.com/quiz/military-tactics-george-patton-

quiz?acct=00f6a7d2cf2656566c6578c8d8ce8c3a03\&utm_term=00fc8881c4693f0 e0f793adb3f4602021 f\&utm_source $=$ outbrain\&utm_medium $=$ paid\&utm_campaig $\mathrm{n}=$ Patton(desktop)\&mkcpgn=i600008337\&sg_uid=6UOC6UYIQ8u9x1Zp4vAQ4 w.

"Monument to General Patton." https://aomda.org/en/content/monument-general-pattonarlon.

"Muppet Wiki." https://muppet.fandom.com/wiki/Patton.

"Palm Springs Walk of Stars." http://www.palmsprings.com/walk-of-stars/.

"The Patton Alliance: George S. Patton Jr. Legacy." http://www.pattonalliance.org.

"Patton and His Third Army Living Historians." http://www.pattonthirdarmy.com/.

Patton, Ben. "What Would General Patton Do in Iraq and Afghanistan?" http://www.huffingtonpost.com/ben-patton/general-patton-iraqafghanistan_b_1371117.html.

"Patton Community Center." https://detroitmi.gov/departments/parksrecreation/community-recreation-centers/patton-community-center.

"Patton Legacy Sports: George S. Patton, Jr. OLY." http://www.pattonlegacysports.org.

"Patton Receives Union Internationale de Pentathlon Moderne HOF Induction." https://www.army.mil/article/185645/.

"The Patton Society." http://www.pattonhq.com/member.html.

"Patton Veterans Project." https://pattonveteransproject.org/mission-history/.

"Podcast Insights." https://www.podcastinsights.com/podcast-statistics/.

"Rhine Crossing Memorial Builds Metaphoric Bridge." https://www.army.mil/article/184917/rhine_crossing memorial_builds_metaphori c_bridge.

"Stephen Ambrose Historical Tours: In Patton's Footsteps." https://stephenambrosetours.com/tour/in-pattons-footsteps-the-battle-ofnormandy-tour/.

Swanson, Clare. "The Bestselling Books of 2014." https://www.publishersweekly.com/pw/by-topic/industrynews/bookselling/article/65171-the-fault-in-our-stars-tops-print-and-digital.html.

"The Army's Vision and Strategy." https://www.army.mil/about/. Accessed September $11,2020$.

"The U.S. Army Chief of Staff's Professional Reading List." https://history.army.mil/html/books/105/105-1-1/index.html.

"Top 25 Greatest War Movies of All Time (The Ultimate List)." https://www.imdb.com/list/ls055731784/.

"U.S. Army "The Big Picture" TV Show Operation Amigo 73742." https://archive.org/details/73742TheBigPictureOperationAmigo.

Wang, Victor. "Student Petition Urges English Department to Diversify Curriculum." Yale News (May 26, 2016). https://yaledailynews.com/blog/2016/05/26/studentpetition-urges-english-department-to-diversify-curriculum/.

"What the Grievance Study Hoax Means." https://www.chronicle.com/article/What-theGrievance/244753. 
Woolner, David. "The "Special Relationship" between Great Britain and The United States Began with FDR." (July 22, 2010). https://rooseveltinstitute.org/specialrelationship-between-great-britain-and-united-states-began-fdr/. 


\section{APPENDIX A: KEY TERMS}

Archetype: involuntary manifestations of unconscious processes whose existence and meaning can only be inferred; symbols that represent abstract meaning that is easily recognizable. ${ }^{856}$

Autobiographical Memory: The memory of events that a person/people personally experienced.

Collective: Group of people who share common interests or objectives.

Collective Memory: The subjective conceptualization of the past by a specific group of people (who do not necessarily have autobiographical memory of the past) that is not reducible to the concept of truth. ${ }^{857}$

Commemoration: An active form of remembering together; a form of remembrance by a collective.

Communitas: The feeling of belonging or comradeship between individuals within a period of liminality. ${ }^{858}$

${ }^{856}$ C. G. Jung, The Archetypes and the Collective Unconscious, trans. R. F. C. Hull (Princeton University Press, 1990), 155.

${ }^{857}$ Maurice Halbwachs, On Collective Memory (Chicago: University of Chicago Press, 1992).

858 Victor W. Turner, The Ritual Process: Structure and Anti-structure, (New York: Aldine De Gruyter, 1969), 95. 
Cult: In this text the use of the word "cult" refers to Emile Durkheim's notion of a combination or system of rites, feasts, and various ceremonies that recur periodically and meet the need for people in a collective to strengthen the bond between them. ${ }^{859}$

Heritage: Something handed down from the past as a tradition.

Hero: A mythological or legendary figure, often of divine descent, endowed with great strength or ability; an illustrious warrior; an inspirational person admired for achievements and noble qualities; or one who shows great courage. ${ }^{860}$

History: An objective interpretation of the meaning of past events based on facts and empirical evidence and viewed from the perspective of those who lived during a particular time.

Legacy: Something handed down from the past, as from an ancestor or predecessor.

Legend: A cultural representation of the past that implies a fictitious tale.

Liminality: A stage within a transformational process in which members lack status as full members of an organization. ${ }^{861}$

Mechanical Solidarity: The consciousness of a collective evidenced through prescribed punishments due to violations of laws, regulations, or social norms; the codification of normative behaviors. ${ }^{862}$

Memorialization: The process of preserving memory of people or events that can be viewed in the form of commemorations, ceremonies, or monuments.

${ }^{859}$ Emile Durkheim and Karen Fields. The Elementary Forms of Religious Life (New York: Free Press, 1995).

860 Merriam-Webster Online, s.v. "hero," accessed January 19, 2020, http://www.merriam-webster.com/dictionary/hero.

861 Victor W. Turner, The Ritual Process: Structure and Anti-structure, (New York: Aldine De Gruyter, 1969), 95.

862 Emile Durkheim. The Division of Labor in Society (New York: Free Press, 2014). 
Memory: The subjective view of the past as seen through the eyes of the present.

Memory Workers: Stakeholders who create forms of public memory or promulgate agenda-based narratives of the past.

Nostalgia: An imagined narrative that is best described as a dreamlike memory that helps people escape the present and think fondly of the past. ${ }^{863}$

Organic Solidarity: The willing dedication and appreciation that individuals in a collective have for each other based upon a division of labor or specialization. ${ }^{864}$

Past: Things that happened.

Projection: The telling and retelling of a particular narrative with the intent for an acceptance (reception) of that narrative.

Public Memory: Manifestations of collective memory, or the purposeful and symbolic engagement of the past, that take place in a public sphere.

Reception: The internalization and acceptance of narrative messaging (projection).

Remembrance: The outward, performative expression of memories, undertaken so that they may not be forgotten entirely.

Rites: Periodic commemorations, feasts, and public festivals that assure cohesion and the continuity of a collective identity over time. ${ }^{865}$

Rituals: Commemorations that symbolize a shared past and sense of obligation to that past. See also "rites."

863 Dictionary.com, s.v. "nostalgia," accessed September 17, 2020, https://www.dictionary.com/browse/nostalgia/. ${ }^{864}$ Emile Durkheim. The Division of Labor in Society (New York: Free Press, 2014). 865 Emile Durkheim and Karen Fields. The Elementary Forms of Religious Life (New York: Free Press, 1995). 
Subculture: A cultural group within a larger culture, often having beliefs or interests at variance with those of the larger culture. 


\section{APPENDIX B: INTERVIEW GUIDE}

Pseudonym:

Date:

Thank you again for taking the time to participate in this study. My name is Nathan Jones and I am a Ph.D. student in sociology and history at the University of Louisville. This interview is expected to take 30 to 50 minutes. First, I need to discuss the consent form with you. [Review concent form and obtain signatures]

The essense of this interview is to ascertain whether or not heroes are important to you, can they be useful, and if so, what are the characteristics of those people whom you consider heroes. Generally, I will be asking questions about your thoughts about heroes in society and where you may have learned about them.

Okay, lets get started.

1. Is there someone you consider a hero? If so, who is it and why?

- Is there anyone else? Why do you consider that person a hero?

- Where did you find out about that person or where do you go to get information about him/her? Books, films, TV, museum, etc.?

2. How would you define a hero? What characteristics are important?

- What single words would you use to describe a hero?

3. Do you find anything inspirational about people that you consider heroes? If so, what?

- Is it important that it be possible to emmulate them? Why or why not? 
- Is it important for heroes to look like you or have similar backgrounds? Why or why not?

4. Do you think that heroes are important or useful in any way?

- Does it depend on the situation?

- If they are important, for what reasons? [Prompt if requested: moral, intellectual, leadership, special abilities, victory, courage, perserverance, etc.]

- If not, why do you suppose people have heroes?

- Do you think there are other effects heroes can have on people?

- For whom are heroes important? [For you, a particular group, and institution, society, a nation?]

- Can stories of heroes bring people closer together or create a sense of belonging? Why or why not?

5. Do you think your generation's heroes are different from your parents' or grandparents' heroes?

- Which particular heroes do you have in mind?

- How are the heroes different or similar?

6. During your time in the ROTC program, which officers from the past have you been introduced to, if any?

- Any specifics you can recall?

- Are any of these stories inspirational? Elaborate....

- How were these stories presented to you? [Prompt if requested: in lectures, videos, homework or paper assignments, guest speakers, reading assignments, museum visits, etc.] 
- Do you prefer any of the ways these stories were presented over others? If so, which did you find more effective?

7. Do you consider any military figure - past or present - a hero?

- If so, why do you consider them so?

- Does that peson inspire you? How?

- Is it more their military achievements or something personal about them that inspires you?

8. Have you heard of General George S. Patton? [IF ANSWER IS “NO,” STOP INTERVIEW HERE]

- If so, how/where did you learn about him?

- Have you seen the movie Patton (1970) starring George C. Scott?

- If you have seen the film, what impression(s) of Patton did the movie leave you with?

- Has General Patton been used as an example in your military training?

- If so, describe how he has been used.

9. In your own words, how would you describe Patton?

10. Are you inspired by General Patton's story? If so, what specifically?

- How much do you think that Patton's story inspires or can inspire your peers?

Finally, to wrap things up, please complete this questionnaire containing a few background questions. [Administer questionnaire]

THANK YOU FOR PARTICIPATING IN THIS INTERVIEW! 


\section{APPENDIX C: BACKGROUND QUESTIONNAIRE}

Pseudonym:

Date:

Instructions: Please answer the following ten questions. For multiple choice questions, please mark the answer(s) that applies.

1. What is your military affiliation? (Check all that apply)

$\square$ I am a ROTC Cadet

$\square$ I am prior active duty

$\square$ I am prior Reserve or National Guard

$\square$ I am a member of the Reserve or National Guard

$\square$ I am in the Simultaneous Membership Program

2. Have you ever served in the military (not counting ROTC)?

o YES

o NO

3. If you have served, how many years?

4. Do you have any family members who served in the military? (check all that apply)

$\square$ brother
$\square$ sister
$\square$ father
$\square$ mother
$\square$ spouse
$\square$ aunt/uncle
$\square$ cousin
$\square$ grandparent

5. What is your desired branch? 
Pseudonym:

Date:

6. What is your age?

7. What is your gender?

o male

o female

o other (write-in):

8. What is your racial identity/ethinicity?

o Native American

o Asian American

o Pacific Islander American

o African American

o Puerto Rican

o Other Hispanic American

o Middle Eastern American

o European American/White

o two or more races/ethnicities

o other(s) (write-in):

9. What college class are you?

o freshman

o sophomore

o junior

o senior

o graduate/post-baccalaureate

10. What is/are your major(s) or intended major(s)?

Thank you for participating! 


\title{
CURRICULUM VITA
}

\author{
Nathan C. Jones, M.A. \\ Department of Interdisciplinary Studies \\ Houchens Building, Suite 105 \\ University of Louisville \\ Louisville, KY 40292 \\ nathan.jones.1@louisville.edu
}

\section{EDUCATION}

Ph.D. Interdisciplinary Studies (Applied Sociology and History)

University of Louisville, Anticipated Completion December 2020

M.A. History

Graduate Certificate in Museum Studies

University of Missouri-St. Louis, 2010

B.A. History

Summa Cum Laude, University of Oklahoma, 2008

A.A. Criminal Justice

Northeastern Oklahoma A\&M College, 1999

RELATED ACADEMIC TRAINING

Basic Museum Training Course, Center of Military History, 2015

Manager Development Course, United States Army, 2014

Supervisor Development Course, United States Army, 2014

Modern Archives Institute, National Archives and Records Administration, 2012

Classroom Instructor Course, United States Air Force, 2007

EXHIBITIONS

"General George S. Patton, Jr.: Leader, Legend, Legacy"

The General Patton Museum, Fort Knox, KY, 2017

"Army Leadership Foundations"

The General Patton Museum, Fort Knox, KY, 2012-2014

"The Civil War in Missouri"

Missouri History Museum, St. Louis, MO, 2008-2010

"The West the Railroads Made"

The Saint Louis Mercantile Library, St. Louis, MO, 2009 
"The West the Railroads are Making: A Photographic Journey"

The Saint Louis Mercantile Library, St. Louis, MO, 2009

"Welcome Home: OIF and OEF Veterans Return to St. Louis"

The Soldiers Memorial and Military Museum, St. Louis, MO, 2009

\section{PUBLICATIONS AND PAPERS}

"Testing His Mettle: George S. Patton and the Development of the U.S. Tank Corps in World War I." In Lafayette Nous Voilà! L'engagement Américain en France, 1917-1918, edited by Olivier Chaline and Olivier Forçade. University of Paris Sorbonne, 2020.

"Cracking the Kriemhilde Stellung: The Combined Actions of the Fifth, Forty-Second, and Thirty-Second Divisions During the Battle of the Meuse-Argonne." In $A$ Companion to the Meuse-Argonne Campaign, edited by Edward Lengel. WileyBlackwell, 2014.

"Charting a New Course: The Craft of Curation and the Visitor-Centered Museum." Collections 10, 2 (2014): 218-229.

"Advancing the Practice: a Report of the US National Curator's Committee Ethics Subcommittee on the 2014 Curatorial Survey and Core Competencies Projects." In ICOFOM Study Series 44, L'Harmattan, 2014

"Is the Curator Dead? Redefining the Role of Curators in the Visitor-Centered Museum.” In CurCom's Update, March 2012

\section{NOTABLE POLICY DEVELOPMENTS}

Curators Core Competencies, American Alliance of Museums Curators Committee, 2014

U.S. Army Career Plan 61 for Museum Curators, Historians, Museum Specialists, and Archivists, 2012

\section{PROFESSIONAL PRESENTATIONS}

"Testing His Mettle: George S. Patton and the Development of the U.S.

Tank Corps in World War I' Presented at the Ohio River Valley Historical Conference and at the Society of the Cincinnati Conference (Lafayette nous voilà! L'engagement Américain en France, 1917-1918) at the University of Paris - Sorbonne, 2017

"General George S. Patton, Jr.: Lessons in Leadership and Organizational Development." Presented to senior leadership of the Third U.S. Army at Camp As-Sayliyah, Doha, Qatar, 2017

"Advancing the Practice: A Report on the US National Curators' Committee Ethics Subcommittee on the 2014 Curatorial Survey and Core Competencies 
Projects " Paper Presented for the International Committee for Museology at the $36^{\text {th }}$ Annual Symposium, l'Université Paris-Sorbonne, Paris, France, 2014

"Patton: Born for Command"

Guest speaker at the Paul Sawyier Library, Frankfort, KY, 2014

"Redefining the Role of Curators in the Visitor-Centered Museum"

Session presentation and live webinar at the Annual Meeting of the American

Alliance of Museums, Minneapolis-St. Paul, MN, 2013

"The Rebirth of the Curator"

Guest speaker and discussion leader at the Annual Meeting of the American

Alliance of Museums, Minneapolis-St. Paul, MN, 2012

"One Year and Thirty Seconds: Public Portrayal of the Doolittle Raid"

Paper presented at the Oklahoma Association of Professional Historians Conference, Oklahoma City University, Edmond, OK, 2008

CURATOR, HISTORIAN, AND MUSEUM EXPERIENCE

The General George Patton Museum of Leadership

Curator/Interim Director, 2010-Present

1-138 Infantry Regiment, Missouri National Guard

Regimental Historian, 2010-2020

Missouri History Museum

Assistant Curator, Military Arms and Equipment, 2008-2010

MILITARY EXPERIENCE

Missouri Army National Guard, 1-138 Infantry Regiment

Infantry Rifle Company First Sergeant (Retired), 2010-2020

United States Air Force Reserve, $507^{\text {th }}$ Air Refueling Wing

SERE (Survival, Evasion, Resistance, and Escape) Instructor, 2004-2010

United States Army, 1-502 Infantry Regiment, $101^{\text {st }}$ Airborne Division

Infantry Squad Leader and Pre-Ranger Instructor, 1999-2004

\section{MUSEUM SERVICE ACTIVITIES}

National Program Committee, American Alliance of Museums (AAM), 2014

Standing Committee on Ethics, AAM Curators Committee (CurCom), 2013-2018

CurCom Executive Board Member, AAM, 2012-2018

Southeastern Museums Conference (SEMC) Representative (CurCom), 2012-2018

AWARDS, GRANTS, AND FELLOWSHIPS

University of Louisville History Department Research Travel Grant, 2014

Superior Civilian Service Award for Exhibit Development, U.S. Army, 2012-2013

E. Desmond Lee Graduate Fellowship, University of Missouri-St. Louis, 2008-2010 
President's Honor Role, University of Oklahoma, 2007-2008

Dean's Honor Role, University of Oklahoma, 2007-2008

LANGUAGES

English - native language

French - speak semi-fluently and read/write with competency

MEMBERSHIPS AND PROFESSIONAL ASSOCIATIONS

Heterodox Academy

Society of Military History

American Alliance of Museums

Phi Alpha Theta

Veterans of Foreign Wars

Sons of Union Veterans of the Civil War

Sons of the American Revolution

\section{RESEARCH AND INTELLECTUAL INTERESTS}

Cultural history of collective memory

Phenomenology of the use of iconography in institutional transformation processes

General George S. Patton's influence on military education and training, 1946-Present

History of collective memory influenced by General George S. Patton's legacy, 1941-

Present

Sociology of identity creation, constructivism, and meaning making in museums

The American National Guard experience in the Great War, 1914-1918

U.S. military history during the interwar years, 1919-1941

General George S. Patton's life, career, and related material culture, 1885-1945

Popular uses of history in museums and American culture

Museum curatorial professionalization

Military vexillology, heraldry, iconography, semiotics, and culture 